\title{
INTERNATIONAL DATA COLLECTION AND ANALYSIS
}

\author{
Prepared for \\ U.S. Department of Energy \\ Under Contract No. EN-77-C-01-5072
}

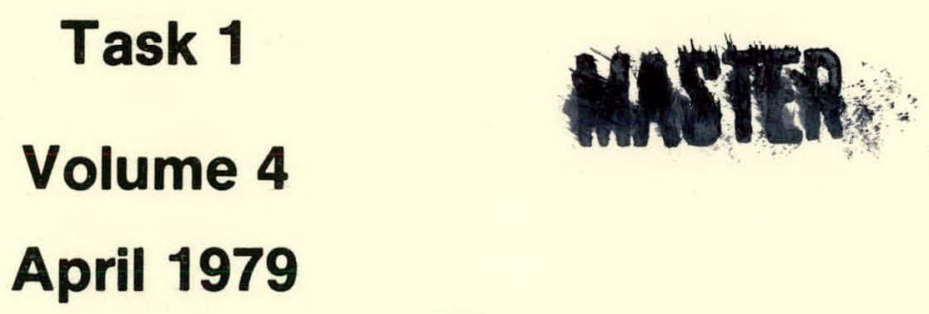




\section{DISCLAIMER}

This report was prepared as an account of work sponsored by an agency of the United States Government. Neither the United States Government nor any agency Thereof, nor any of their employees, makes any warranty, express or implied, or assumes any legal liability or responsibility for the accuracy, completeness, or usefulness of any information, apparatus, product, or process disclosed, or represents that its use would not infringe privately owned rights. Reference herein to any specific commercial product, process, or service by trade name, trademark, manufacturer, or otherwise does not necessarily constitute or imply its endorsement, recommendation, or favoring by the United States Government or any agency thereof. The views and opinions of authors expressed herein do not necessarily state or reflect those of the United States Government or any agency thereof. 


\section{DISCLAIMER}

Portions of this document may be illegible in electronic image products. Images are produced from the best available original document. 


\section{INTERNATIONAL DATA COLLECTION}

\section{AND}

ANALYSIS

Task 1

Volume 4

Prepared for

U.S. Department of Energy

Under Contract No. EN-77-C-01-5072

by

Judith B. Fox

John J. Stobbs

Dan M. Collier

James S. Hobbs

Apr11 1979

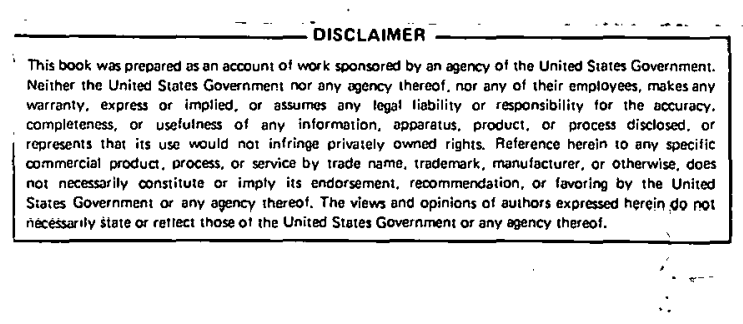

NUCLEAR ASSURANCE CORPORATION

24 Executive Park Woct

Atlanta, Georgia 30329

Telephone: (404) 325-4200

Telex: 549567

NAC $C-7904$
Weinbergatrassc 9

8001 Zurich, Switzerland

Telephone: (01) 470844

Telex: $\quad 57275$

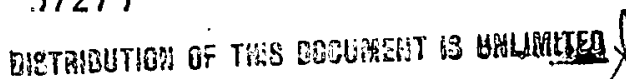


NOTICE

The information contained in this report has been prepared by Nuclear Assurance Corporation based upon data obtalned from sources we consider reliable and/or calculations consistent with technical principles we consider applicable. Neither Nuclear Assurance Corporation nor any individual author makes any warranty or representation, expressed or implied, with respect to the accuracy, completeness, or usefulness of the information contained in this report, or assumes any responsibility for liability or damage which may result from the use of any information disclosed in this report.

Recipients are invited to contact NAC (800-241-0507, Atlanta or 014708 44 , Zurich) concerning any portion of this report or for further indepth analysis. 
TABLE OF CONTENTS

\begin{tabular}{|c|c|c|c|}
\hline Volume & Section & Title & Page \\
\hline 1 & $\begin{array}{l}1 \\
2 \\
3 \\
4 \\
5 \\
6\end{array}$ & 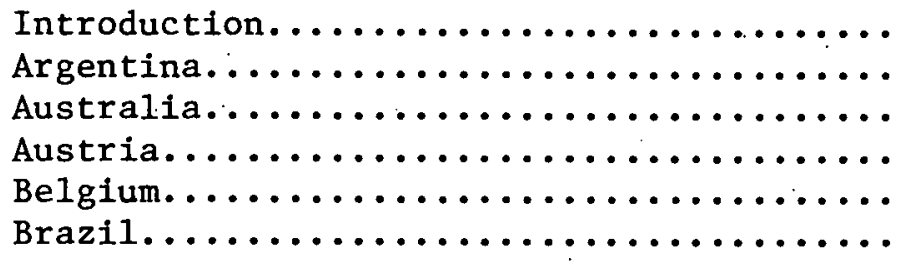 & $\begin{array}{l}1 \\
\text { Argentina-1 } \\
\text { Australia-1 } \\
\text { Austria-1 } \\
\text { Belgium-1 } \\
\text { Brazil-1 }\end{array}$ \\
\hline 2 & $\begin{array}{r}7 \\
8 \\
9 \\
10 \\
11\end{array}$ & 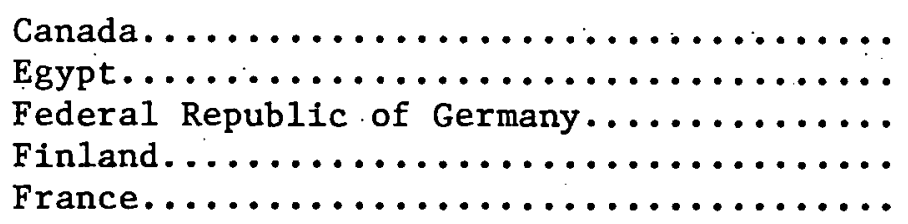 & $\begin{array}{l}\text { Canada-1 } \\
\text { Egypt-1. } \\
\text { Fed. Rep. of Germany-1 } \\
\text { Finland-1 } \\
\text { France-1 }\end{array}$ \\
\hline 3 & $\begin{array}{l}12 \\
13 \\
14 \\
15 \\
16 \\
17\end{array}$ & 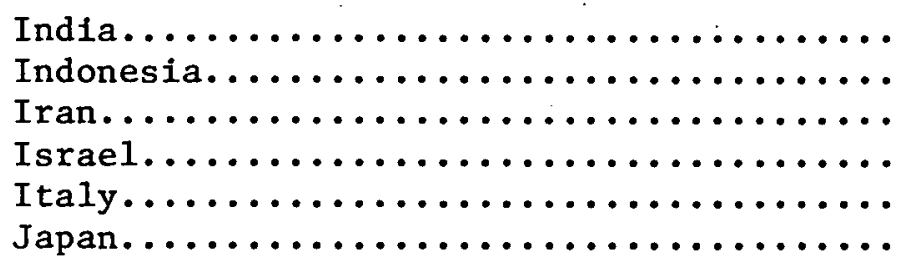 & $\begin{array}{l}\text { India-1 } \\
\text { Indonesia-1 } \\
\text { Iran-1 } \\
\text { Israe1-1 } \\
\text { Italy-1 } \\
\text { Japan-1 }\end{array}$ \\
\hline 4 & $\begin{array}{l}18 \\
19 \\
20 \\
21 \\
22 \\
23 \\
24\end{array}$ & 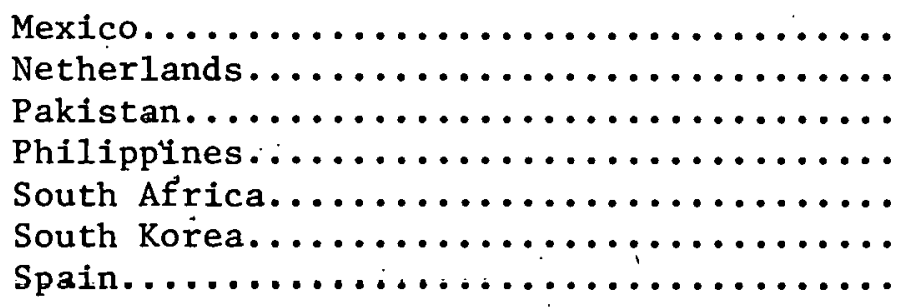 & $\begin{array}{l}\text { Mexico-1 } \\
\text { Netherlands-1 } \\
\text { Pakistan-1 } \\
\text { Philippines-1 } \\
\text { South Africa-1 } \\
\text { South Korea-1 } \\
\text { Spuln-1 }\end{array}$ \\
\hline $\begin{array}{l}\text { Ap } \\
\text { Ap }\end{array}$ & 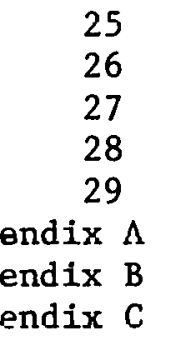 & 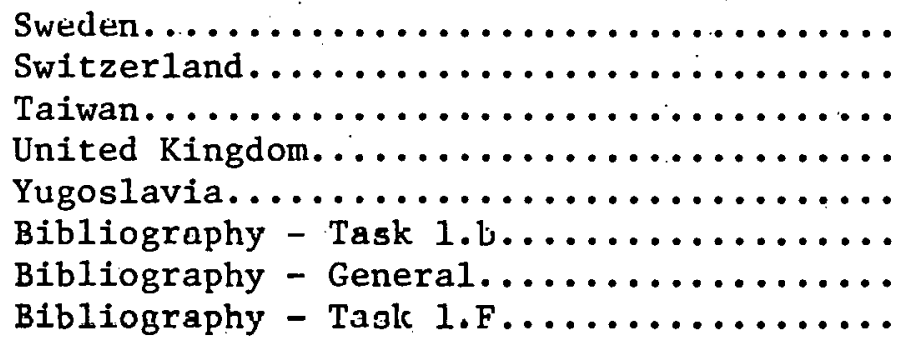 & $\begin{array}{l}\text { Sweden-1 } \\
\text { Switzerland-1 } \\
\text { Taiwan-1 } \\
\text { United Kingdom-1 } \\
\text { Yugoslavia-1 } \\
\text { A-1 } \\
\text { B-1 } \\
\text { C-1 }\end{array}$ \\
\hline
\end{tabular}


SECTION 18

MEXICO 


\subsection{PROJECTED INDIGENOUS ENERGY RESOURCES, DEMANDS AND RELATED INFORMATION}

\section{INDIGENOUS RESOURCES}

Mexico is a country rich in energy resources. It has oil, coal, gas, uranium, hydro and geothermal energy and sunshine!

Coal, which is mined and utilized basically by the steel industry, is expected to increase its share of the energy demand. Economically recoverable reserves are put at 698 million tonnes (ref. 1.2) and have been stated at that value also in reference 1.1 . However, the figure for total indigenous resources has changed radically. In 1973 it was put at 5,316 million tonnes. In 1975 the estimate was 997.0 million tonnes. The World Energy Conference paper "Energy Resources Availability in Mexico to Satisfy Its Demand" (ref. 1.8) states that the Consejo de Recursos Minerales is undertaking a serious exploration program that will permit a better definition of the coal potential of the Country.

For crude oil the proved recoverable quantity has increased from 414.3 million tonnes in 1973 (ref. 1.1) to 481.0 million tonnes in 1975 (ref. 1.2). No figure for the total resource is available. The International Petroleum Encyclopedia notes reserves at 1507 million tonnes in 1977. Recently discovered are several oilfields under one locating name: Chicontepec Field, estimated to contain 100 billion barrels of oil and 40 trillion cubic feet of natural gas. Studies are now underway to determine what percentage of deposits are feasibly recoverable.

No figures for shale oil are obtainable:

Economically recoverable gas quantities have increased from $309.5 \mathrm{~km}^{3}$ in 1973 to $337 \mathrm{~km}^{3}$ in 1975 (refs. 1.1 and 1.2). Further increases are occurring.

In 1976 total hydro-electric energy was $44 \mathrm{TWh}$. The economically recoverable energy is estimated at 80.9 TWh and maximum theoretical capacity 99.4 TWh (from ref. 1.2).

Extensive work is in progress to exploit geothermal energy using steam for electricity production. There are 310 thermal zones and 20 geothermal fields in Mexico. U1timate capacity is expected to be 500 MW by 1980 . It is hoped by the end of the century, $7 \%$ of Mexico's power will be produced by geothermal sources. Several additional studies are in progress along the $20^{\circ} \mathrm{N}$ latitude. The figure given in Table 18.1 .1 is the actual energy produced in 1975.

Uranium reserves are estimated at about 5,500 tonnes $\mathrm{U}_{3} 0_{8}$, with an additional 2,800 tonnes inferred. Extensive exploration may raise these figures in the future. None of the deposits have been subjected to economic or viability analyses. 
At the Second Pacific Basin Conference (September 25-29, 1978), Mexico speakers provided the following tabulation of national resources:

$\begin{array}{cc}\begin{array}{c}\text { Hydrocarbons (0il and Gas) } \\ \text { Proven } \\ \text { Potential }\end{array} & 23,250\left(10^{6}\right) \mathrm{m}^{3} \\ \text { Hydro Power } \\ \text { Installed } \\ \text { Potential. } & 18,600\left(10^{6}\right) \mathrm{m}^{3} \\ \text { Coal Proven } & 6,000 \mathrm{MW} \\ \text { Potent1al } & 25,000 \mathrm{MW} \\ \text { Geothermal. } & \\ \text { Pessimistic } & 2,400 \mathrm{million} \text { tonnes } \\ \text { Potential } & 8,000 \mathrm{million} \text { tonnes } \\ \text { Uranium } & \\ \text { Proven } & 2,000 \mathrm{MW} \\ \text { Potential } & 13,000 \mathrm{MW} \\ \end{array}$

\section{ENERGY SUPPLY}

Production of hard coal was 5.128 million tonnes (ref. 1.5). This compares with the value given in reference 1.33 of 5.17 million tonnes.

Crude oil production was at the rate of 39.7 million tonnes (ref. 1.5), 42.1 million tonnes (ref. 1.33) and 36.6 million tonnes (ref. 1.2). In 1976, Mexico exported $140,000 \mathrm{~b} / \mathrm{d}$ oil, increasing to $200,000 \mathrm{~b} / \mathrm{d}$ in 1977 , $280,000 \mathrm{~b} / \mathrm{d}$ in early 1978 , and possibly increasing to $500,000 \mathrm{~b} / \mathrm{d}$ by the end of 1978. The U. S., according to Energy Daily (12/14/78), is getting more than $80 \%$ of it. Other countries exported to are: Israel, Spain, Sweden and U.K., with other likely customers: Italy, Brazil, and Japan.

Natural gas production has been steadily increasing and stands at $14.99 \mathrm{~km}^{3}$ (ref. 1.5) $23.05 \mathrm{~km}^{3}$ (ref. 1.33). The small imported quantity is supplied entirely by the United States.

Uranium production has been very modest.

TATTERNG OF ENERGY USE

No coal consumption occurs in the household or transport sectors.

Petroleum is consumed in all sectors with transportation making the highest demand.

Though industry is the major consumer of natural gas, a significant quantity is used for electrical generation.

All figures for Table 18.1.3 come from Paper 1.4-7, reference 1.8. 
Energy demand in Mexico is expected to increase at a rate of between $3.5 \%$ and $6.0 \%$ per year over the period 1975-2000. In the same period, electricity demand is expected to grow at a somewhat faster annual rate of between $4.4 \%$ and $9.6 \%$. As a result of this difference in growth rates, electricity production will account for some $40 \%$ of the total primary energy demand in 2000 compared with on 1 y $25 \%$ in 1975 . These forecasts are presented in Table 18.1.4.

The United Nations Economic Commission for Latin America forecasts a total primary energy demand of $11,350 \times 10^{12} \mathrm{Btu}$ (285.1 million tonnes oil equivalent) for Mexico in 2000 (ref. 1.33) which is considerably higher than the figures presented in Table 18.1.4. However, the United Nations forecasts represents a continuation of the $7 \%$ per year growth in energy demand experienced from 1971 to 1975 (ref. 1.5) and therefore appear somewhat optimistic. The United Nations forecast of electricity demand for the year 2000 is 404 TWh which is considerably greater than the medium growth scenario forecast of $235 \mathrm{TWh}$ and again appears to be a rather optimistic projection of the recent historic growth in demand.

Table 18.1.5 shows that the importance of nuclear electricity as a source of energy is expected to increase significantly during the period 1975 to 2000 reducing the contribution of oil and gas to the primary energy supply from $84 \%$ in 1975 to only $61 \%$ in 2000 . It can also be seen that geothermal energy is expected to be providing some 2.5 TWh of electricity by 2000. This will derive from a number of plants with a total capacity in excess of 500 MW (ref. 1.33).

Projections of installed nuclear capacity indicate a total of 14,500 MW in 2000. The Comision Economica para America Latina (CEPAL) projected a capacity of 46,000 MWe in 2000. However, an increase to this level would result in an extremely low average capacity factor (approximately 35\%).

A sharp increase in the activity level of the Mexican nuclear energy program will be needed even to meet the lower 14,500 MW projection. At present, there are no official plans for further nuclear power plants after the current two reactors under construction. This position appears to be caused by a combination of the massive fossil fuel resources and the unfavorable experience in constructing the first reactors. 


\section{INDIGZNOUS ENERGY RESOURCES}

Table 18.1.1

\begin{tabular}{|c|c|c|c|}
\hline$\therefore$ & $\begin{array}{c}\text { Economically } \\
\text { Recoverable Reserves }\end{array}$ & $\begin{array}{c}\text { Total Indigenous } \\
\text { Resources }\end{array}$ & $\begin{array}{l}\text { Location of } \\
\text { Identified Reserves }\end{array}$ \\
\hline Hard Coal (million tonnes) & 698 & $\because 997$ & Altiplanicie Mexicana \\
\hline Soft Coal (million tonnes) & 0 & $\dot{0}$ & \\
\hline $\begin{array}{l}\text { Crude } 011 \text { (million tonnes) } \\
\text { Shale } 011 \text { (m1llion tonnes) }\end{array}$ & Not AVicilable & Not Available & $\begin{array}{l}\text { Litoral + Istmica } \\
\text { Chicontepec, Reforma, } \\
\text { Samaria }\end{array}$ \\
\hline Natural Gas (cubic $\mathrm{km}$ ) & 337 & Not Available & $\begin{array}{l}\text { Litoral + Istmica } \\
\text { Coahuila, Nuevo Leon }\end{array}$ \\
\hline Uranium (thousand tonres $\mathrm{U}_{3} \mathrm{O}_{8}$ ) & 5.5 & 8.3 & Chihauhua \\
\hline Hydro Power (TWh/year) & 80.9 & 99.4 & Isthmus, Sierra Madre \\
\hline Geothermal (IWh/year) & $(0.491) *$ & Not Available & $\begin{array}{l}\text { Hidalgo, Mexicali, Pathe, } \\
\text { Ahuachapan }\end{array}$ \\
\hline
\end{tabular}

* Energy produced in 2975 
ENERGY SUPPLY 1975

Table 18.1.2

\begin{tabular}{|c|c|c|c|c|c|c|c|c|}
\hline \multirow[t]{2}{*}{ Resource } & \multirow{2}{*}{\multicolumn{2}{|c|}{$\begin{array}{l}\text { Indigenous } \\
\text { Supply }\end{array}$}} & \multicolumn{3}{|c|}{ Imports } & \multicolumn{3}{|c|}{ Exports } \\
\hline & & & Total & & $\%$ from US & Total & $\%$ to & $\overline{\text { US }}$ \\
\hline Hard Coal (million tonnes) & & 5.128 & 0.580 & & 100 & 0 & 0 & \\
\hline Soft Coal (million tonnes) & & 0 & 0 & & 0 & 0 & 0 & \\
\hline Crude 011 (million tonnes) & & 39.729 & 0 & & 0 & 5.50 & 0 & \\
\hline Shale oll (million tonnes) & Not & Available & 0 & & 0 & 0 & 0 & \\
\hline Natural Gas (cublc km) & & 14.99 & 0.267 & & 100 & 0 & 0 & \\
\hline Uranium (thousand tonnes $\mathrm{U}_{3} \mathrm{O}_{8}$ ) & Not & Available & 0 & & 0 & 0 & 0 & \\
\hline Electrictty (TWh) & & 43.29 & 0.38 & & 100 & 0.10 & 100 & \\
\hline
\end{tabular}


Table 13.1 .3

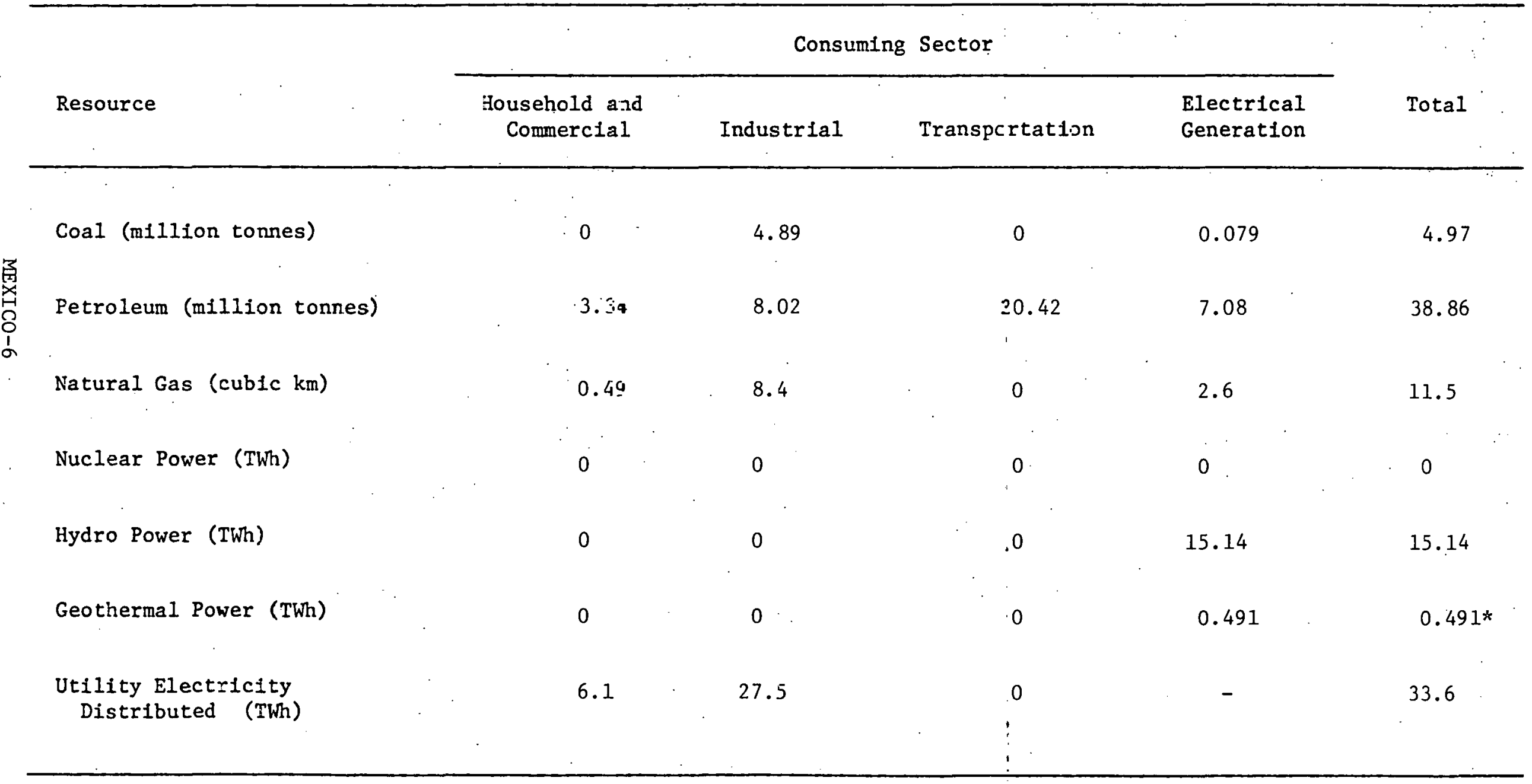

* In 1974 


\section{FORECASTS OF ANNUAL ENERGY DEMAND AND ELECTRICITY DEMAND}

Table 18.1.4

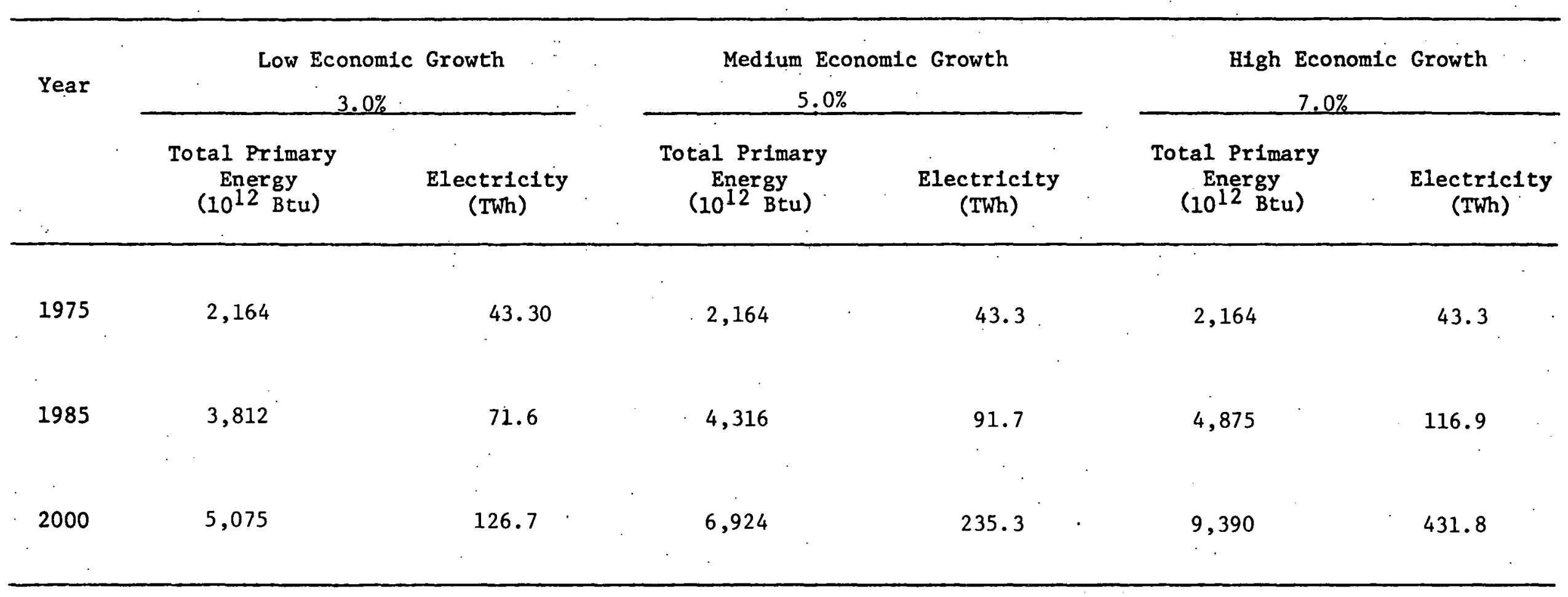


בONSUR:PZION OF ENERGY RESOURCES

Zable 18.1.5

\begin{tabular}{|c|c|c|c|c|c|c|c|}
\hline \multirow[t]{2}{*}{ Resource } & \multirow[t]{2}{*}{ Standard Unit } & \multicolumn{3}{|c|}{$\begin{array}{l}\text { Annual Consumption of } \\
\text { Standard Units }\end{array}$} & \multicolumn{3}{|c|}{$\begin{array}{l}\text { Energy Consumption } \\
\quad\left(10^{12} \mathrm{BtU}\right)\end{array}$} \\
\hline & & 1975 & 1985 & 2000 & 1975 & 1985 & 2000 \\
\hline Coal & Millicn Tormes & 5.71 & 10.9 & 19.2 & 158.5 & 302 & 534 \\
\hline Crude 011 & Mi111en Tomnes & 30.31 & 60.8 & 65.6 & 1307.3 & 2590 & 2830 \\
\hline Natural Gas & Cublc km & 14.49 & 26.4 & 38.5 & 520.7 & 950 & 1385 \\
\hline Hydro Power & TWh & 15.14 & 30.3 & 48.7 & 172.2 & 345 & 554 \\
\hline Other Renewables & TWh & 0.49 & 1.1 & 2.5 & 5.6 & 13 & 28 \\
\hline Nuclear Power & TWh & - & 10.2 & 140.0 & - & 116 & 1593 \\
\hline Uranfum & Thousand Tonnes $\mathrm{U}_{3} \mathrm{~J}_{8}$ & 0 & 0.25 & 2.88 & - & - & - \\
\hline
\end{tabular}


18.2 NUCLEAR HISTORY, CAPABILITY, COMMITMENT AND TRENDS

COMMERCIAL NUCLEAR POWER PLANTS

Table 18.2.1

\begin{tabular}{lllccrr}
$\begin{array}{l}\text { Facility } \\
\text { Name }\end{array}$ & Utility & Vendor & $\begin{array}{c}\text { Facility } \\
\text { Type }\end{array}$ & $\begin{array}{c}\text { Capacity } \\
\text { (MWe net) }\end{array}$ & Status* & COD \\
\hline Laguna Verde-1 & $\begin{array}{l}\text { Comision Federal } \\
\text { de Electricidad }\end{array}$ & GE & BWR & 645 & U & Mar 1982 \\
Laguna Verde-2 & $\begin{array}{l}\text { Mexico } \\
\text { GE }\end{array}$ & BWR & 645 & U & May 1983 \\
\hline
\end{tabular}

* O-Operational; U-Under Construction; P-Planned 
Table 18.2.2

Year PWR BWR Magnox AGR CANDU Other FBR $\quad \begin{aligned} & \text { Firm }+ \\ & \text { Planned } \\ & \text { Cumulative Cumulative } \\ & \text { Total Projection }\end{aligned}$

Pre- 1978
1978
1979
1980
1981

1982

1983

1984

1985

1986

1987

1988

1989

1990

1991

1992

1993

1994

1.995

$1996^{\circ}$

1997

1998

1999

2000
615

645

$600 \quad 600$

$600 \quad 600$

$600 \quad 600$

$600 \quad 600$

$600 \quad 600$

$600 \quad 600$

$600 \cdot 600$

$\begin{array}{rrr} & 645 & 645 \\ & 1290 & 1290 \\ & 1290 & 1290 \\ & 1290 & 1290 \\ & 1290 & 1290 \\ & 1290 & 1290 \\ 1200 & 1290 & 1290 \\ & 1290 & 2490 \\ 1200 & 1290 & 3690 \\ 1200 & 1290 & 4890 \\ 1200 & 1290 & 6090 \\ & 1290 & 7290 \\ & 1290 & 7290 \\ 1200 & 1290 & 8490 \\ & 1290 & 9690 \\ & 1290 & 10890 \\ & 1290 & 12090 \\ & 1290 & 13290 \\ 1290 & 14490\end{array}$

A11 reactors projected after Laguna Verde 1 and 2 must be considered highly speculative. 
NUCLEAR REACTOR VENDORS

\section{Overview}

Mexico has no domestic nuclear reactor vendors.

\section{Nuclear Reactor Vendor Support Industries}

There are current1y no heavy component reactor support industries in Mexico. Extensive training in all aspects of power engineering (including those needed to support nuclear power plant construction) is underway. Based upon Mexico's nuclear growth plans, support industries could be expected to develop in the late 1980's. 
NUCLEAR FUEL CYCLE FACILITIES

\section{Overview}

The sole current Mexican fuel cycle activity is in uranium exploration, mining, and milling. Presently Mexico has only modest uranium reserves and resources, but only small portions of the nation have been explored.

A small pilot plant ( $\sim 88$ tons of ore per day) at Villa Aldama has previously produced about 40 MTU. The plant, which had been idle, resumed operation in 1978. A major mine/mill complex is planned for operation at Pena Blanca in Tamaulipos with a capacity of 2200 TPD. When complete in 1982 it should yield approximately 380 MTU per year. A possible mill may be operational in the late 1980s in the La Coma, Buena Vista area of Nueva Leon. The capacity will be about 2200 I'PJ).

Some research is carried out in fuel fabrication; eventually this could lead to indigenous fuel fabrication capability. 
CURRENT AND PLANNED FACILITIES

Table 18.2.3

\begin{tabular}{|c|c|c|c|c|c|c|}
\hline $\begin{array}{l}\text { Facility } \\
\text { Name }\end{array}$ & Location & $\begin{array}{l}\text { Facility } \\
\text { Type }\end{array}$ & $\begin{array}{c}\text { Capacity } \\
\text { MT/YR }\end{array}$ & Status & Year & Shareholdings \\
\hline Sierra Pena Blanca & $\begin{array}{l}\text { Tamaulipos, } \\
\text { Chihualua }\end{array}$ & Uranium Mine & & Construction & 1982 & Mexican Government \\
\hline La. Com:a Ranch & Nueva Leon & Uranium Mine & & Planned & 1988 & Mexican Government \\
\hline Sierra Pena Blanca & $\begin{array}{l}\text { Tamaulipos, } \\
\text { Chihualua }\end{array}$ & Uranium Mill & 385 & Construction & 1982 & Mexican Government \\
\hline
\end{tabular}


NUCLEAR DEVELOPMENT OUTLOOK SUMMARY

Vested Interests in Current Reactor Technologies and Fuel Cycles

Currently Mexico has no vested interest in specific nuclear reactor technology or fuel cycles. Such interests might develop as Mexico's nuclear program matures and vendor support industries or fuel cycle industries emerge.

Current Trends in Nuclear Development Programs

Mexico's primary emphasis is now upon development of knowledge concerning its pranium resources. 


\subsection{NUCLEAR TECHNOLOGY CAPACITY AND RESOURCES}

\section{PROFESSIONAL LABOR FORCE PROFILE}

\section{Table 18.3 .1}

Available information presents the following data for 1971:

4,064 Engineers and Scientists engaged in R\&D 
Table 18.3.2

\section{Institution}

Universidad Alexander von Humboldt

Universidad Anahuac

Universidad Autonoma de Baja California

Universidad Autonoma Metropolitan

Universidad. Autonoma de San Luis Potosi

Universidad Autonoma de Chihuahua

Universidad de Guadalajara

Universidad La Salle

Universidad Nacional Autonoma de Mexico

Universidad Regiomontana

Universidad de Sonora

UnIverstdad de1 Sureste

Universidad Veracruzana

Instituto Politecnico Nacional

Instituto Techologico regional de Tlalnepantla

Centro de Estudios Universitarios de Monterrey

Instituto de Ciencias y Artes de Chiapas

Instituto Tecnologico y de Estudios Superiores de Occidente $\underline{\text { Location }}$

Mexico City

Mexico City

Mexicali

Mexico Gity ..

San Tuis Pntngi

Chihuahua

Guadalajara

Mexico City

Mexico City

Monterrey

Hermosillo

Campeche

Xalapa

Mexico City

Tlalnepantla

Monterrey

Tuxtla Gutierrez

Guadalajara 
Table 18.3.3

\author{
Name \\ Instituto de Investigaciones \\ Electricas (IIE)
}

\section{Location}

Cuernavaca

Mexico City

Salazar

\section{Main Activities}

1. Research in advanced technologies for generation of electric power.

2. Develop technique for manufacture in Mexico of generative and transmission equipment.

3. Train technicians.

4. Consultants to CFE.

Nuclear power development.
Nuclear Energy (INEN)

1. National Institute of Nuclear Research

2. URAMEX

3. National Commission on Nuclear Security and Safeguards

Nuclear Energy Center
Basic nuclear physics research and utilization of radioisotopes. 
EEY PRIVATE NUCLEAR RESEARCH ORGANIZATIONS

$$
\text { Table 18.3.4 }
$$

Name

Owner

Location

Main Activities

Not Applicable 
RESEARCH AND TEST REACTORS

List of Reactors

Table

18.3 .5

\section{Facility}

Name

$\mathrm{RCN}$

Sur-Mexico
Location

Salazar

Mexico City
Owner

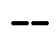

$-$
Constructor

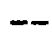

$--$
Facility Facility Status Type MW(th) Status* COD

U-Zr hydride:

Solid homog. 0

0

1968

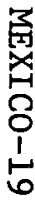


INDIGENOL'S CAPAEILITY TO DESIGN AND SUPPLY RESEARCH AND TEST REACTORS AND FUEL SERVICES Scmmary of Reactor Orders by Vendor and Courtry

Vendor

Facility
Country

Table 18.3 .6

Niame

Facility

Facflity Status

Type

MW(th) Statis* $^{*}$

Scope of

COD Services

Not Applicable

* O-Operational; U-Under Construc Iion; P-Planaed; S-Shutdown 
SUMMARY OF FUEL SERVICES FOR RESEARCH AND TEST REACTORS

Table 18.3 .7

Facility

Name

Location

Facility

Type

$\frac{\text { Capacity Status }}{\text { MT/YR }}$

Year

Shareholdings.

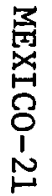

Not Applicable

* 0-Operational; U-Under Constructicn; P-Planned; S-Shutdown 


\section{ECONOMIC DATA PROFILE}

Table 18.4.1

$\begin{array}{llll}\text { GDP (Current million \$) } & -72,277(1977) & \text { Inflation Rate } & -20 \%(1977) \\ \text { Exports (million \$) } & -4,093(1977) & \text { Imports (million \$) }-5,486(1977) \\ \text { Per Capita Income (\$) } & -1,119(1977) & \text { Disposable Income (\$) }-386(1963) \\ \text { Mnnetary Unit } & - \text { Peso } & \text { Exchange Rate (/US\$) }-22.6(4 / 77) \\ \text { Pnpulation (mil1inn) } & -64.59(1977) & \end{array}$

18.4.2 GOVERNMENTAL NUCLEAR ENERGY R\&D BUDGET

NATIONAL INSTITUTE OF NUCLEAR ENERGY (INEN)

\section{Research}

Exploration

Development

Other including radiation applications TOTAL
FY 75 (\$ MILLION)

$$
\begin{array}{r}
4.0 \\
4.0 \\
2.4 \\
5.6 \\
16.0
\end{array}
$$

Energy R\&D budgets of all other government agencies are very small: 
GOVERNMENTAL SUPPORTED NUCLEAR R\&D INDUSTRY, UNIVERSITIES

AND NATIONAL LABORATORIES

Table 18.4.3

\begin{tabular}{|c|c|c|c|}
\hline $\begin{array}{l}\text { Industry } \\
\text { University or } \\
\text { Laboratory } \\
\end{array}$ & $\begin{array}{l}\text { Program } \\
\text { Area } \\
\end{array}$ & $\begin{array}{c}\text { Budget } \\
\$ \text { (Millions) } \\
\end{array}$ & $\begin{array}{c}\text { Key } \\
\text { Personnel } \\
\end{array}$ \\
\hline $\begin{array}{l}\text { Mexican Institute of } \\
\text { Electrical Research } \\
\text { (IIE) }\end{array}$ & $\begin{array}{l}\text { Power research in } \\
\text { general }\end{array}$ & -- & $\begin{array}{l}\text { Dr. Carlos Valez- } \\
\text { Ocon, Director } \\
\text { General }\end{array}$ \\
\hline $\begin{array}{l}\text { National Polytechnic } \\
\text { Institute }\end{array}$ & $\begin{array}{l}\text { Training, subcritical } \\
\text { assembly }\end{array}$ & -- & -- \\
\hline $\begin{array}{l}\text { National Institute of } \\
\text { Nuclear-Energy } \\
\text { (INEN) }\end{array}$ & $\begin{array}{r}\text { Nuclear power } \\
\text { development }\end{array}$ & -- & $\begin{array}{l}\text { Vizcano Murray } \\
\text { Director General }\end{array}$ \\
\hline $\begin{array}{l}\text { National Autonomous } \\
\text { University of } \\
\text { Mexico (UNAM) }\end{array}$ & $\begin{array}{l}\text { Nuclear power } \\
\text { research }\end{array}$ & -- & -- \\
\hline
\end{tabular}

18.4.4 ROLE OF PRIVATE INDUSTRY IN NUCLEAR ENERGY R\&D

There is essentially no energy $R \& D$ in the private sector. All energy R\&D is carried out in government laboratories or in universities funded by the government.

ECONOMIC PROFILE OF REACTOR VENDORS AND FUEL CYCLE FACILITIES

Table 18.4.5

Name Share Capital $\underline{\text { Assets }}$

Not Applicablc 


\subsubsection{MODE OF FINANCING OF NUCLEAR POWER PLANTS}

Capital investments in nuclear power plants are expected to reach $\$ 171$ million in 1980 and $\$ 240$ million in 1985 . Trade sources report CFE favors making future nuclear power equipment purchases from a single source, as a package which includes long-term financing.

In 1973, the arrangements for financing Laguna Verde I, were made with Wells Fargo Bank and U.S. Export-Import Bank. A \$54.2 million loan agreement was signed to support a $\$ 60.2$ million sale of U.S. equipment, materials and services for construction. These two companies each committed to half of the loan. The terms were for repayment of $\$ 37.6$ million in 30 equal semi-annual installments, beginning 5/10/78. In addition, $\$ 16.6$ million will be repaid in ten semt-annual installments also beginning 5/10/78. The borrower was Comision Federal de Electridad which will make a $10 \%$ cash payment, or $\$ 6$ million, on the total U.S. costs. 


\subsubsection{ENERGY POLICY - BASIC LEGISLATION}

1. Article 27 of the Mexican Constitution reserves for the National Government all energy responsibilities.

2. Created Federal Electricity Commission (CFE) 1939.

3. National Nuclear Energy Commission (CNEN) established 1955.

4. Established the National Institute of Nuclear Energy 1972.

5. Instituto Nacional de Energia Nuclear (INEN) replaced CNEN in 1972.

6. Institute of Electrical Research (IIE) created 1976.

7. INEN split into three separate entities (1978):
a. National Institute Nuclear Research
b. URAMEX
c. National Nuclear Safety Commission 


\subsubsection{GOVERNMENTAL STRUCTURE FOR NUCLEAR ENERGY POLICY AND R\&D}

\section{LEGISLATIVE}

Congress consists of the Chamber of Deputies (213 members) and the Senate ( 60 members). Other than acting positively on Presidential initiatives, Congress plays virtually no role in the energy area.

\section{EXECUTIVE}

The executive branch is dominant. Executive power is vested in the President (Lopez Portillo) who promulgates and executes the laws of Congress and, by delegation from the Congress, legislates by executive decree in certain areas. The President heads a Cabinet composed of 15 Ministries.

Other organizations with energy responsibility include:

ORGANIZATION

Comision Federal de Electricidad

National Energetics Commission (NEC)

National Council of Science and Technology (CONACYT)

Institute for Electricity Research (IIE)

\section{RESPONS IBILITY}

Autonomous government department with primary responsibility for all energy activities.

Coordinates national energy pol-. Juan Eibenschutz, icy. Reports directly to the powerful Minister. of Patrimony (over natural resources) (policy making, advises on future energy policy and carries out energy studies).

Funds research in universiries and government laboratories.

Coordinates general research in electricity and power, advisory function, in nuclear power program, particularly in preparation of regulatory standards.

\section{KEY INDIVIDUALS}

Hugo Cervantes del Rio, Director General

The National Institute of Nuclear Energy has been replaced by three viganialione:

\author{
National Institute \\ of Nuclear Research \\ URAMEX - Uranio de \\ Mexico \\ National Commission on \\ Nuclear Security and \\ Safeguards
}

Concentrates on nuclear research and development programs.

Uranium exploration and exploitation.

Investigates and establishes standards for safety of nuclear power facilities. 


\subsubsection{ORGANIZATION FOR IMPLEMENTATION OF NUCLEAR ENERGY POLICY AND R\&D}

Ultimate responsibility for policy is President of the Republic at present. Lopez Portillo, inaugurated 1976 for six years.

National Energetics Commission - advises the Administration on future energy policy. Chairman is also Secretary of Patrimony and Industrial Development Jose Andris Oteyza.

National Institute of Nuclear Research - concentrates on nuclear research and development programs'.

URAMEX - Uranio de Mexico - uranium exploration and exploitation.

National Commission on Nuclear Security and Safeguards.

IIE - coordinates general research in electricity and power and has no advisory function in preparation of standards. Engr. Guillermo Fernandez de la Garza - Executive Director.

Primary responsibility for energy activities is CFE - Hugo Cervantes del Rio Director. 


\subsubsection{NUCLEAR ENERGY POLICY AND OBJECTIVES}

According to Mexico's current 6-year plan (1977-82), the emphasis will be on development of petroleum and gas resources although developments will also go ahead on coal, hydro, geothermal, and nuclear inputs.

Laguna Verde 1 and 2 are not expected to be completed until 1982 and 83 . The feeling is that nuclear energy can be utilized on a large scale as soon as breeder reactors, which permit utilization of nuclear wastes, are available internationally, and at a national level, when operational experience of the Laguna Verde plants are achieved. No new nuclear energy installations are seen to be built in Mexico, so it will not be a basis for their energy development in the near future.

The energy policy ohjectives are to:

a) promote the diversification of our primary sources of energy in order to diminish the dependency in oil and gas.

b) promote the coordination of planning in the energy sector as a whole.

c) promote a more efficient utilization of energy.

d) develop the local manufacture of capital goods associated to the energy. sector.

e) promote research and development activities in the energy field. 


\subsubsection{NUCLEAR ENERGY R\&D - STATUS AND OUTLOOK}

The nuclear program during the Echeverria administration was quite ambitious - 40 million $\mathrm{kw}$ of electric power produced by 40 nuclear reactors by year 2000. This has been scaled down sharply by the incumbent Administration. The program is being approached with caution, with priority in research given to hydroelectric and geothermal projects. There is consideration given now to a yellowcake concentrating plant to process proven resources of 8,000 tons of uranium located in the border states of Chihauhau Tamaulipas.

\subsubsection{NUCLEAR ENERGY R\&D - PRIORITIES}

The main priority for an energy R\&D program is total energy selfsufficiency. Though emphasis is placed primarily on other fuel resources at present, much effort is being directed toward development of nuclear capability. The recognized need for a more defined governmental structure to regulate nuclear $R \& D$ efforts is being implemented in establishing within the INEN a National Institute for Nuclear Research.

Though reliance on international assistance in the areas of engineering design, construction and maintenance of power plant systems will continue, there is a gradual increase in Mexican contribution in all phases of the fuel cycle. Reduction of this kind of foreign dependence is very attractive to Mexico, economically.

\subsubsection{ROLE OF GOVERNMENT IN NUCLEAR FACILITIES CONSTRUCTION AND OPERATION}

The Mexican government controls virtually all energy related activities. The CFE is responsible for the construction and operation of nuclear facilities. The INEN is responsible for licensing activities and with INEN is the Naitonal Nuclear Safety Commission which will establish safety standards. The IIE coordinates preparation of all regulatory standards. 
18.6.1 NON-NUCLEAR ENERGY FACILITIES AND FUEL SUPPLY

MEXICO-30 
ENERGY GENERATION FACILITIES IN EX-STENCE AND FIRMLY PLANNED PRODJCING 100 MWe (net)

Table 18.6.1 (Continued)

\begin{tabular}{|c|c|c|c|c|c|c|c|}
\hline $\begin{array}{l}\text { Facility } \\
\text { Name }\end{array}$ & Location. & $\begin{array}{l}\text { U=ility/ } \\
\text { Owner }\end{array}$ & Vendor & $\begin{array}{c}\text { Fazility } \\
\text { Type } \\
\text { (Fue.l Type) } \\
\end{array}$ & $\begin{array}{l}\text { Capacity } \\
\text { (MWe net) }\end{array}$ & Status* & $\underline{C O D}$ \\
\hline Monterrey & $\begin{array}{l}\text { San Nicolas de } \\
\text { la Gorza }\end{array}$ & $\mathrm{C} \Xi \mathrm{DE}$ & & Stean. & 477 & 0 & \\
\hline \multirow[t]{3}{*}{ San Jeronimo } & Monterrey & $C=D E$ & & Stean & 105 & 0 & \\
\hline & & $\begin{array}{l}\text { Grupo Znd. de } \\
\text { Monterzey }\end{array}$ & & Steam & 152 & 0 & \\
\hline & & $\begin{array}{l}\text { Grupo Ind. ce } \\
\text { Monterzey }\end{array}$ & & Steam & 127 & 0 & . \\
\hline Temascal & San Miguel & CIDE & & Hydro & 154 & 0 & \\
\hline Mazatepec & $\begin{array}{l}\text { Ilatlauqui- } \\
\text { tepec }\end{array}$ & CFDE & & Hydro & 209 & 0 & \\
\hline Necaxa & Juan Galindo & $\begin{array}{l}\text { C-a. de Luz y } \\
\text { Fuerza del Centro }\end{array}$ & & Hydro & 115 & 0 & \\
\hline Guaymas I & Sonora & CFDE & Bechtel (A-E) & Stean & 150 & $\mathrm{U}$ & $7 / 79$ \\
\hline Guaymas II & Sonora & CFDE & Bechtel $(A-E)$ & Stean & 150 & $\mathrm{U}$ & $1 / 80$ \\
\hline E1 Novillo & Sayapa & CFDE & & Hydra & 90 & 0 & \\
\hline Poza Rica & Molocan & CFDE & & Stean & 117 & 0 & \\
\hline
\end{tabular}

* 0-Operationa1; U-Under Construction; P-Planned; S-Sratdown 
ENERGY GENERATION FA:ILITIES IN EXISTENCE AND FIRMLY PLANNED PRODUCING 100 MWe (net)

Table 18.6.1 (Continued)

\begin{tabular}{|c|c|c|c|c|c|c|c|}
\hline $\begin{array}{l}\text { Facility } \\
\text { Name } \\
\end{array}$ & Location & $\begin{array}{l}\text { Utility/ } \\
\text { Owner } \\
\end{array}$ & Vendor & $\begin{array}{l}\text { Type of } \\
\text { Fuel } \\
\end{array}$ & $\begin{array}{l}\text { Capacity } \\
\text { (MWe net) }\end{array}$ & $\begin{array}{c}\text { Commissioning } \\
\text { Date }\end{array}$ & Status* \\
\hline Manzanilla & Colima & CFDE & Bechtel (A-E) & Steam & 1200 & $1981, \begin{array}{l}1982,1984 \\
1985\end{array}$ & $\mathrm{U}$ \\
\hline $\begin{array}{l}\text { Rio } \\
\text { Escondido }\end{array}$ & & CFDE & & Coal & 1500 & $1982,1983,1984$ & $\mathrm{U}$ \\
\hline Desemboque & $\begin{array}{l}\text { Gulf } o \equiv \\
\text { Califo }\end{array}$ & CFDE & . & Steam & 600 & $1983, \begin{array}{l}1984,1985 \\
1986\end{array}$ & $\mathrm{U}$ \\
\hline Penitas & & CFDE & & Hydro & 400 & 1985 & $\mathrm{U}$ \\
\hline Carbon II & & CFDE & & Coa1 & 900 & 1985,1986 & $\mathrm{U}$ \\
\hline Caracol & & CFDE & & Hydro & 570 & 1985 & $\mathrm{U}$ \\
\hline Aguamilpa & & CFDE & & Hydro & 540 & 1986 & $\mathrm{U}$ \\
\hline Merida II & Yucatan & & $\begin{array}{l}\text { Comec-Displan } \\
\qquad(A-E)\end{array}$ & Steam & 336 & $\begin{array}{l}1981,1982,1984, \\
1986\end{array}$ & $\mathrm{U}$ \\
\hline $\mathrm{Tu}_{-}^{-} \mathrm{a}$ & $\begin{array}{l}\text { Estado de } \\
\text { Mexico }\end{array}$ & & & Steam & 300 & 1978 & 0 \\
\hline Tanpico & Vera Cruz & CFDE & $\mathrm{WY} / \mathrm{To}$ & Gas/0il. & $\begin{array}{l}566 \\
600\end{array}$ & $\begin{array}{c}1972,1973,1974,1975, \\
1978\end{array}$ & $0 / U$ \\
\hline
\end{tabular}

\footnotetext{
* 0-Operational; U-Uncer Construction; P-Planned; S-Shutdown
} 


\section{ENERGY GENERATION FAIILITIES IN EXISTENCE AND FIRMLY PLANNED PZODUCING 100 MNe (net)}

\section{Table 18.6.1 (Continued)}

Facility

Name

Mazatlan

Cerro

Prieto

Angostura

Chicoasen

\begin{tabular}{|c|c|c|}
\hline Location & $\begin{array}{l}\text { Utility/ } \\
\text { Owner } \\
\end{array}$ & Vendor \\
\hline \multirow[t]{4}{*}{ Sinaloa } & CFDE & $\begin{array}{c}\text { III } \\
B e=h t e 1 ; \lambda-E)\end{array}$ \\
\hline & CFDE & 工o \\
\hline & CFDE & \\
\hline & CFDE & \\
\hline
\end{tabular}

\begin{tabular}{l} 
Type of \\
Fuel \\
\hline Steam \\
Hyd ro \\
Hydro
\end{tabular}

Capacity

(MWe net)

316

300

148

360

1500 \begin{tabular}{c}
$\begin{array}{c}\text { Commissioning } \\
\text { Date }\end{array}$ \\
\hline
\end{tabular}

\section{$\underline{\text { Status* }}$}

$0 / U$

1981

$1969,1976,1977$

0

1978

1980,1981
$\mathrm{U}$

* 0-Operational; U-Under Zonstructior.; P-Elar.nəd; S-Shatdown 
SUMMARY OF ENERGY GENERATION FACILITIES IN EXISTENCE AND PLANNED

Table 18.6.2

$\begin{array}{lc}\text { Year } & \text { Capacity - MWe (net) } \\ 1975 & 11,052 \\ 1980 \\ 1985 \\ 1990 \\ 1995 \\ 2000\end{array}$


LISTING OF FUEL SUPPLY FACILITIES IN EXISTENCE AND FIRVYY PLANNED

Table $\quad 18.6 .3$

Facility

Name

Monterrey

Tigrillo

Other

Arenque

Barcodon

Constituciones
Location

Barrancas

Oaxaca

Coahuila

North Zose,

N.E. District

North Zore,

N.E. District

North Zose,

N.E: District

North Zone,

N.E. District

North Zore,

N. Dis:rict

North Zone;

N. Diszrict

North Zone,

N. District

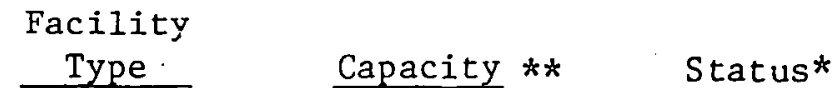

3.7

0

Oil Field

208

0

Oil Field

698

0

Oil Field

101

0

Oil Field

220

0

Oil Fielḋ $\quad 20,858$

0

Oil Field

283

0

Oil Field $\quad 6,176$

0

* O-Operational; U-Under Construction; P-Planned; S-Shutdown

** Oil-barrels/day 


\section{LISTING OF FUEL SUPPLY FACILITIES IN EXISTENCE AND FIRRIY PLANNED}

Table 18.6.3 (Continued)

\begin{tabular}{|c|c|c|c|c|c|}
\hline $\begin{array}{l}\text { Facillty } \\
\text { Name } \\
\end{array}$ & Location & Owner & $\begin{array}{l}\text { Factlity } \\
\text { Type } \\
\end{array}$ & Capacity ** & Status* \\
\hline Zbano-Panuco & $\begin{array}{l}\text { North Zone, } \\
\text { N. District }\end{array}$ & & .0il Field & 6,328 & 0 \\
\hline Tamaulipas & $\begin{array}{l}\text { North Zone, } \\
\text { N. District }\end{array}$ & & Oil Field & 6,837 & 0 \\
\hline Dther & $\begin{array}{l}\text { North Zone, } \\
\text { N. District }\end{array}$ & & Oil Field & 239 & 0 \\
\hline Cabo Neuvo & $\begin{array}{l}\text { North Zone, } \\
\text { S. District }\end{array}$ & & Oil Field & 447 & 0 \\
\hline Isla de Lobos & $\begin{array}{l}\text { North Zone, } \\
\text { S. District }\end{array}$ & & Oil Field & 1,233 & 0 \\
\hline Marsopa & $\begin{array}{l}\text { North Zone, } \\
\text { S. District }\end{array}$ & & Oil Field & 5,114 & 0 \\
\hline Naranjos-C Azul & $\begin{array}{l}\text { North Zone, } \\
\text { S. District }\end{array}$ & & Oil Field & 8,473 & 0 \\
\hline Soledad Norte & $\begin{array}{l}\text { North Zone, } \\
\text { S. District }\end{array}$ & & Oil Field & 1,276 & 0 \\
\hline
\end{tabular}

* O-Operational; U-Under Construction; P-Planned; S-Shutdown ** Oil - barrels/day 


\section{L-STING OF FUEL SUPPLY FACILITIES IN EXISTENCE AND FIRILY ?LANNED}

Table 18.6.3 (Continued;

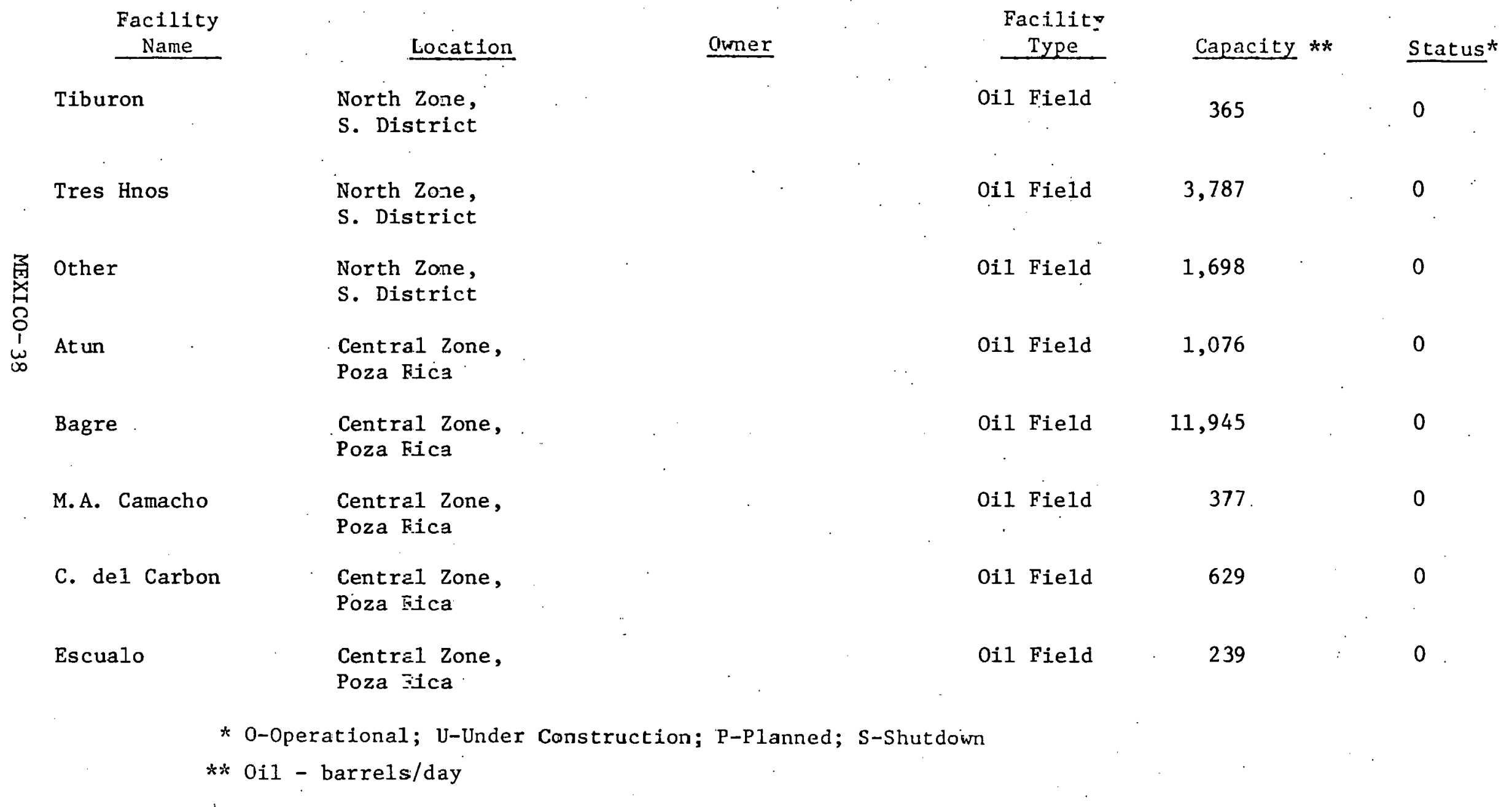


LISTING OF FUEL SUPPLY FACILITIES IN EXISTENCE AND FIRMIY PLANNED

Table 18.6.3 (Continued)

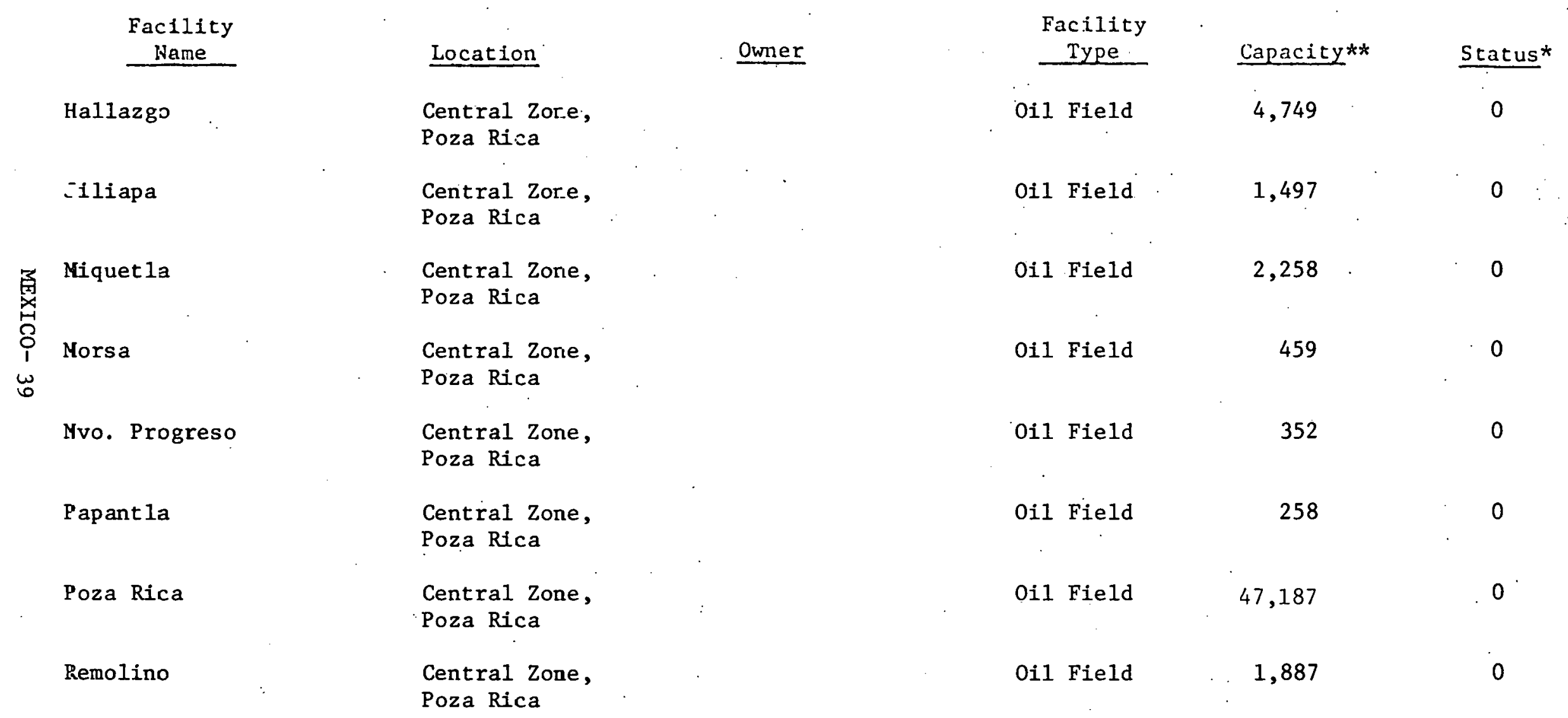

* O-Operational; U-Under Construction; P-Planned; S-Shutdown

** Oil - barrels/day 
LISTING OE FUEL SUPPEY FACILITIES IN EXISTENCE AND FIRrIY PLANNED

Tajle 18.6.3 (Continued)

\begin{tabular}{|c|c|c|c|c|c|}
\hline $\begin{array}{l}\text { Facility } \\
\text { Name } \\
\end{array}$ & Zocation & & $\begin{array}{l}\text { Facility } \\
\text { Type } \\
\end{array}$ & Capacity** & Status* \\
\hline Riachuelo & $\begin{array}{l}\text { Central Zone, } \\
\text { Poza RAca }\end{array}$ & & Oil Field ' & 484 & 0 \\
\hline San Andres. & $\begin{array}{l}\text { Central Zone, } \\
\text { Poza Rica }\end{array}$ & & Oil Field & 29,223 & 0 \\
\hline Other & $\begin{array}{l}\text { Central Zone, } \\
\text { Poza Rica }\end{array}$ & & Oil Field & 6,852 & 0 \\
\hline Acuatempa & $\begin{array}{l}\text { Central Zone, } \\
\text { Nueva Faja, de Ora }\end{array}$ & & Oil Field & 1,541 & 0 \\
\hline Alamo Jardin & $\begin{array}{l}\text { Central Zone, } \\
\text { Nueva Faja, de Ora }\end{array}$ & . & Oil Field & 472 & 0 \\
\hline Copal & $\begin{array}{l}\text { Central Zone, } \\
\text { Naeva Faja, de Oro }\end{array}$ & & Oil Field & 333 & 0 \\
\hline E1 Muro & $\begin{array}{l}\text { Central Zone, } \\
\text { Nueva Faja, de Ora }\end{array}$ & & Oil Field & 4,730 & 0 \\
\hline E. Ordonez & $\begin{array}{l}\text { Central Zone, } \\
\text { Nueva Faja, de Oro }\end{array}$ & & Oil Field : & 1,912 & 0 \\
\hline Meya Cerrada & $\begin{array}{l}\text { Central Zone; } \\
\text { Nieva Faia, de Oro }\end{array}$ & & Oil Field & 440 & 0 \\
\hline $\begin{array}{c}* \text { 0-Operational } \\
* * \text { Oil-barrels/day }\end{array}$ & U-Unier Constriction; P-Planned; & S-Shutdown & 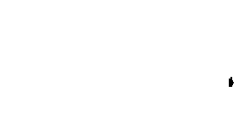 & & \\
\hline
\end{tabular}




\section{LISTING OF FUEL SUPPLY FACILITIES IN EXISTENCE AND FIRRLY PLANNED}

Table 18.6.3 (Continued)

\begin{tabular}{|c|}
\hline Jcotepec \\
\hline Santa Agueda \\
\hline Jthers \\
\hline Angostura \\
\hline
\end{tabular}

Matapionche

Dther

Agata

Suichafa

\begin{tabular}{|c|c|c|c|}
\hline Owner & $\begin{array}{c}\text { Facility } \\
\text { Type } \\
\end{array}$ & Capacity** & Status* \\
\hline & Oil Field & 572 & 0 \\
\hline & Oil Field & $\because 3,824$ & 0 \\
\hline & Oil Field & 744 & 0 \\
\hline ᄂ & Oil Field & 346 & 0 \\
\hline & Oil Field & 623 & 0 \\
\hline & Oil Field & 100 & 0 \\
\hline & Oil Field & 673 & 0 \\
\hline & Oil Field & 18,794 & 0 \\
\hline
\end{tabular}

* O-Operational; U-Under Construction; P-Planned; S-Shutdown

** Oil-barrels/day

Central. Zone,

Zeuva Faja, de Oro

Central Zone,

Zeuva Faja, de Oro

Central Zone,

Zeuva Faja, de Oro

Central Zone,

Vera Cruz

Centra1 Zone, Vera Cruz

Central Zone,

Vera Cruz

Southern Zsne,

Isthmus of Tehuantepec

Southern Zone,

Isthmus of Tehuantepec 
LISTING OE IUEL SUPPLY FACILITIES IN EXISTENCE AND FIRMI PLANNED

\section{Tatle 18.6.3 (Continued)}

Facility

Name

E1 Burro

E1 P1an

Ixhat lan Ote

Los Soldados

Mecoacan

Santa Rosa

Tacuilolapa

Tonala location

Scuthern Zone,

Isthmus of Lehuantepec

Scutiern Zone,

Isthnus of Tehuantepec

Soutiern Zone,

Isthnus of Tehuantepec

Soutiern Zone,

Isthnus of Tehuantepec

Southern Zone,

Isthmus of Tehuantepec

Southern Zone,

Isthmus of Tehuantepec

Southern Zome.

Is.thmus of Tehvantepec

Southern-Zone,

Isthmus of Tehtantepec
Jwner

Facility

Type

Oil Field

Oil Field

Oil Field

Oil Field

Oil Field

Oil Field

Oil Field

Oil Field

\section{Capacity**}

1,050

3,460

1,667

1,378

5,120

170

277

1,384
Status*

0

0

0

0

0

0

* O-Operational; U-Under Construction; P-Planned; S-Shutdown

** Oil-barrels/day 


\section{LISTING OF FUEL SUPPLY FACILITIES IN EXISTENCE AND FIRRLY PLANNED}

\section{Table 18.6.3 (Continued)}

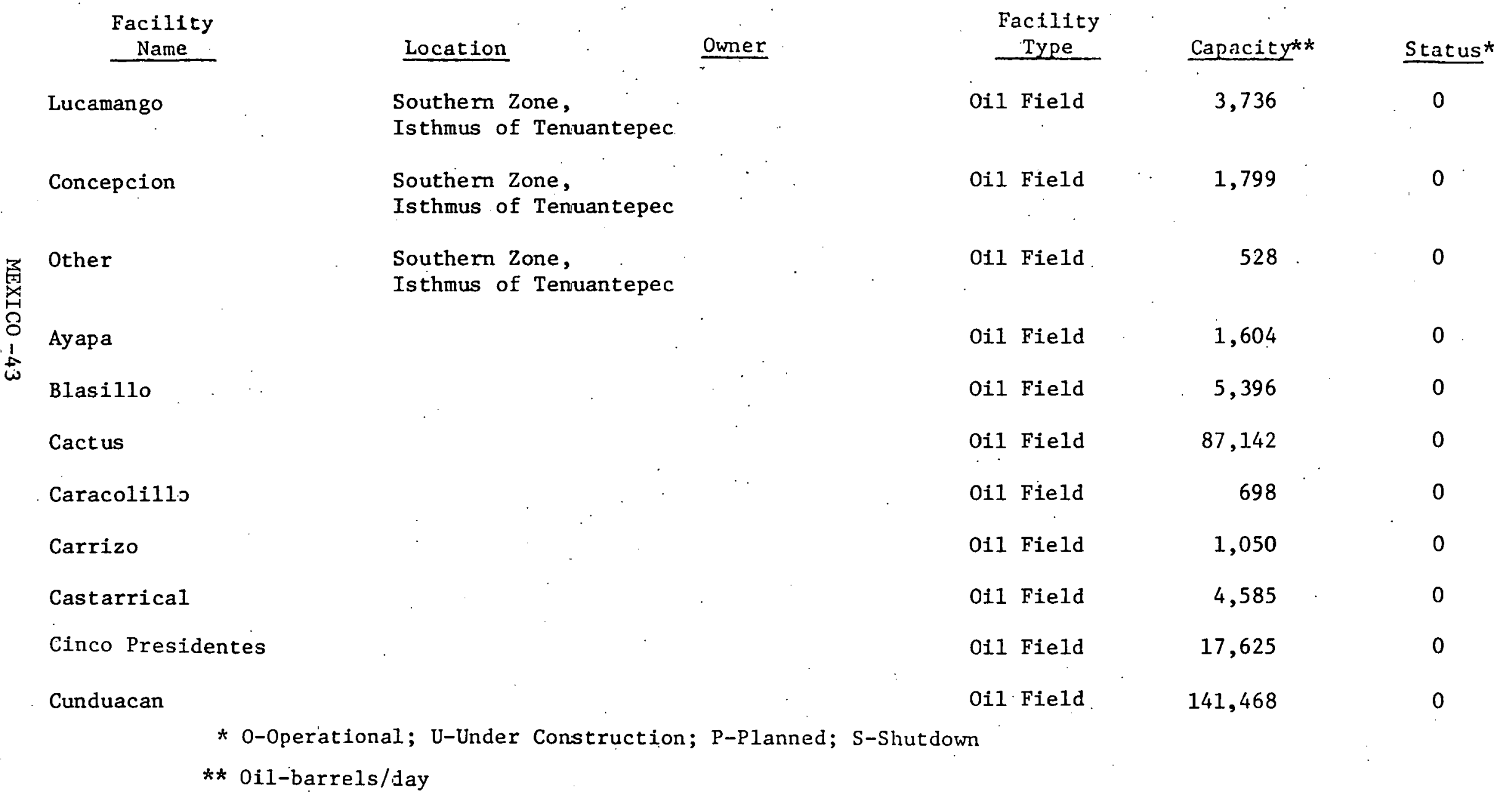


LISTING OF FLEL SUPPLY FACILITIES IN EXISTENCE AND FIEMRY PLANNED

Table 18.6.3 (Zontinued)

Facilfty

Name

El Gope

Iride

La Venta

Magallenes



8 Mecoacan

$\stackrel{1}{\perp}$ Nispero

Ogarrio

Otates

Rio Nuevo

Rodador

Samaria

San Ramon
Owner

Location

Oil Field

oil Field

Oil Field

Oil Field

Oil Field

Oil Field

O1l Field

Oil Field

Dil Field

Oil Field

Dil Field
Capacity**

9,498

15,171

4,523

8,297

3,705

20,788

14,259

2,944

4,051

1,174

287,515

8,290

* O-Operational; U-Under Corstruction; P-Planned; S-Shutdom

** Oil-barrels/dzy
Status*

0

0

0

0

0

0

0

0

0

0

0

0 
LISTING OF FUEL SUPPLY FACILITIES IN EXISTENCE AND FIRMI PLANNED

Table 18.6.3 (Continued)

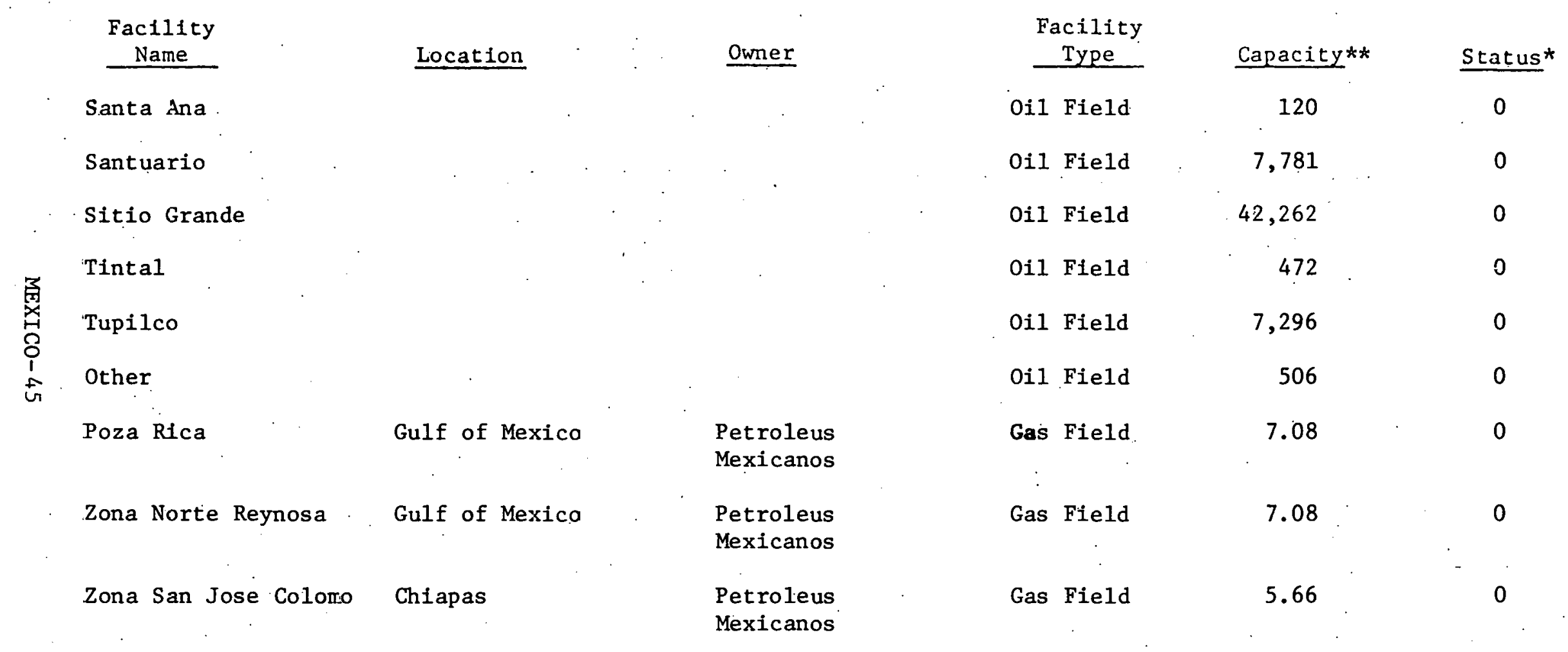

* 0-Operational; U-Under Coistruction; P-Planned; S-Shutdown

** Oil-barrels/day; Natural gas-km ${ }^{3} /$ year 
Table 18.6 .4

RESOURCE

COAL (million tonnes)

Indigenous Supply

13.69

48.57

Imports

$-$

2.79

$--$

Exports

49.38

62.90

lindigenous supp 1 y

11.42

2.62

Exports

SHALE OIL (million tonnes)

Indigenous Supply

0

0

Imports

Exports

NATURAL GAS (cubic kilometers)

Indigenous Supply

32.29

35.98

Imports

2. 52

Exports

5.89

$-$

URANIUM (kilotonnes $\mathrm{U}_{3} \mathrm{O}_{8}$ )

Indigenous Supply

Imports

0.38

15.4

Exports

0.13

0

12.5 
SECTION 19

NETHERIANDS 


\section{INDIGENOUS RESOURCES}

No indigenous resources of coal were reported in reference 1.2. Reference 1.1 gave a total resource of 3,705 million tonnes of which 1,843 million tonnes are economically recoverabie.

A small quantity of oil is available, however there are no figures for the total resource and the economically recoverable amount has been downrated from 37.0 million tonnes in 1972 to 13.0 million tonnes in 1975

(see refs. 1.1 and 1.2 ).

There are no known reserves of oil shale or bituminous sands.

The Netherlands has a considerable quantity of natural gas located principally at Groningen. Figures for economically recoverable reserves of $1,753 \mathrm{~km}^{3}$ are given in ref. 1.1 and 1.2 and have been constant over the period 1971-1975. No figure for the total indigenous resource quantity is available from references 1.1 or 1.2 . Total recoverable reserves are given as $2,404 \mathrm{~km}^{3}$ (ref. 1.26); however no definition of the term is given and this figure has not been included in the tables.

The Netherlands has no sources of hydro or geothermal power and no sources of uranium or thorium.

\section{ENERGY SUPPLY}

No solid fuel production has taken place in the Netherlands since 1974 , though it has an indigenous source. Imports are put at 4.609 million tonnes (ref. 1.5) and 4.67 million tonnes (ref. 1.6). Approximately $20 \%$ of imports come from the United States.

Crude oil production is minimal, reserves being very. small. Comparative figures are 1.573 million tonnes (ref. 1.5), 1.60 million tonnes (ref. 1.6 ) and 1.4 million lunnes (ref. 1.2). Imports are considerable at 55.225 million tonnes (55.61, ref. 1.6) but none of this is supplied by the United States.

Natural gas is the Netherlands' chief indigenous resource (approximately 20 years' supply from current economic reserves at the present rate of extraction). Production stands at $90.14 \mathrm{~km}^{3}\left(90.0 \mathrm{~km}^{3}\right.$, ref. 1.2$)$ of which $48.9 \mathrm{~km}^{3}$ is exported. None of this export goes to the United States. 


\section{PATTERNS OF ENERGY USE}

The majority of imported coal goes to industry. The remainder is used mainly for electrical generation with only a small demand in the household sector (0.22 million tonnes, ref. 1.6).

A large percentage of the Netherlands' crude oil imports are re-exported as petroleum products (approximately 34 million tonnes of imported crude oil).. The remainder is used throughout all sectors.

Natural gas is used in all sectors except transportation and is particularly significant with regard to electrical generation, supplying almost $83 \%$ of energy input to the power stations.

\section{FORECASTS OF ENERCY SUPPLY AND DEMANI)}

The forecasts of energy and electricity demand in the Netherlands presented in Table 19.1.4 show an average annual rate of growth over the period 1975 to 2000 of between $2.8 \%$ and $5.8 \%$ for total primary energy, and of $4.5 \%$ to $9.0 \%$ for electricity demand.

The Commission of the European Communities (ref. 1.16) forecasts a 1985 total energy demand in the Netherlands of $4,088 \times 10^{12} \mathrm{Btu}$ (102.7 million tonnes oil equivalent) which is higher than any of the forecasts shown in Table 19.1.4. The Workshop on Alternative Energy Strategies (ref. 1.14) produced forecasts of primary energy demand in the Netherlands in 1985 ranging from $2,870 \times 10^{12}$ Btu to $4,460 \times 10^{12}$ Btu dependent mainly upon the economic growth rate and the price of oil and also affected by the expected response to energy conservation measures. These are more in accord with the forecasts shown in $\mathrm{Table} 19.1 .4$.

The relative importance of oil and natural gas as a source of cnergy is expected to decline in the periud 1975-1985 (ref. 1.16) as nuclcar energy becomes available, and the breakdown given in Table 19.1.5 shows the effects of a continuation of this trend through to. 2000 . By $2 U U U$ the demand for nuclear electricity is expected to reach 83 TWh which will be supplied by a forecast $5,400 \mathrm{MW}$ total installed capacity. 
Table 19.1.1

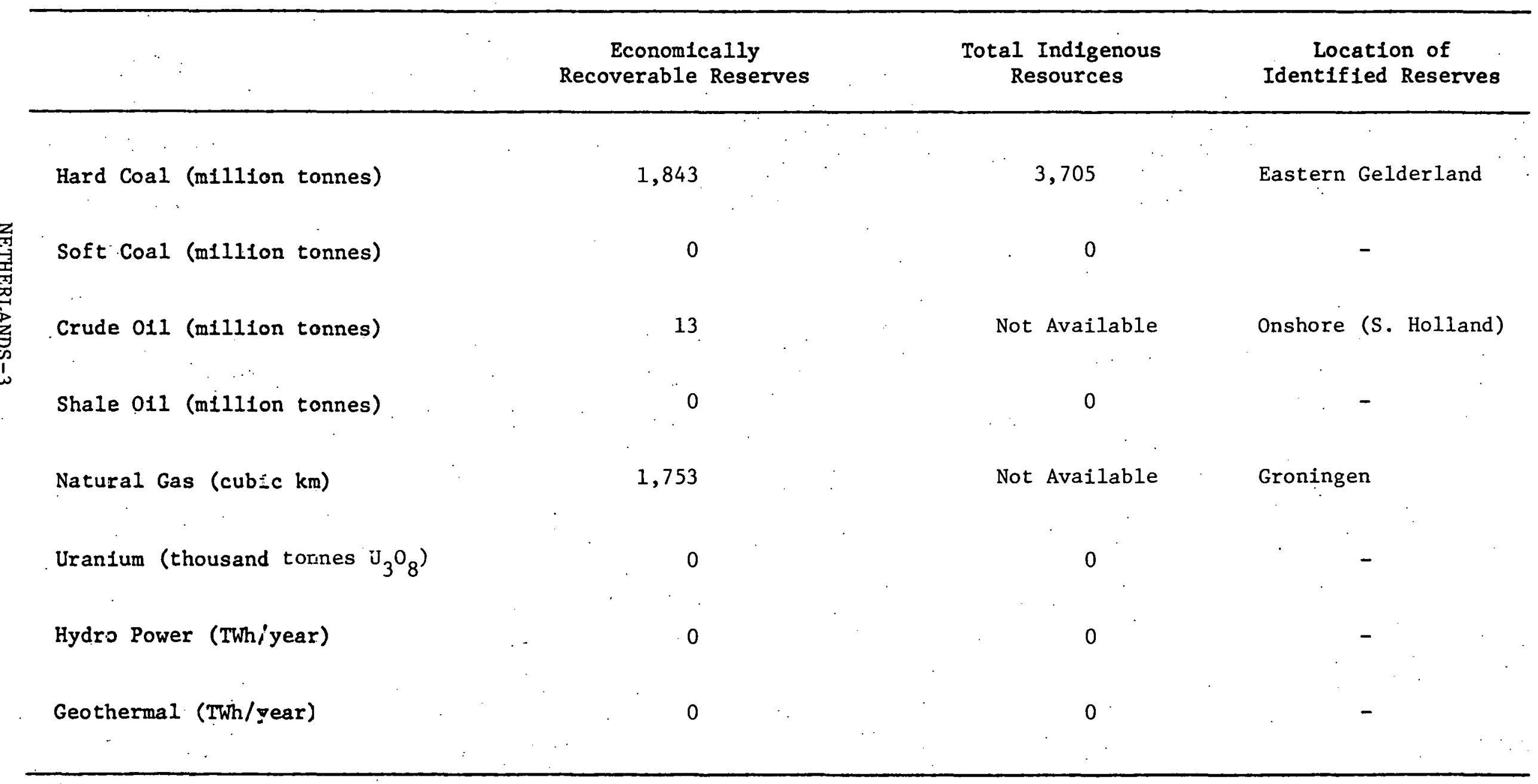


ENERGY SUPPLY 1975

Table 19.1.2

\begin{tabular}{|c|c|c|c|c|c|}
\hline \multirow{2}{*}{ Resource } & \multirow{2}{*}{$\begin{array}{l}\text { Indiger.aus } \\
\text { Supply }\end{array}$} & \multicolumn{2}{|c|}{ IIports } & \multicolumn{2}{|c|}{ Exports } \\
\hline & & Total & $\%$ from US & Total & $\%$ to US \\
\hline Hard Coal (million tonnes) & $0.758^{1)}$ & 4.609 & $20.39 *$ & 0.876 & 0 \\
\hline Soft Coal (milion tonnes) & 0 & 0 & 0 & 0 & 0 \\
\hline Crude 011 (million tonnes) & 1.573 & 55.225 & 0 & 0 & 0 \\
\hline Shale 011 (million tonnes) & 0 & 0 & 0 & 0 & 0 \\
\hline Natural Gas (cubic km) & 90.14 & 0 & 0 & 48.92 & 0 \\
\hline Uranium (thousand tonnes $\mathrm{U}_{3}{ }^{0} \varepsilon$ ) & 0 & .113 & 0 & 0 & 0 \\
\hline Electricity (TWh) & 54.26 & 0.05 & 0 & 0.31 & 0 \\
\hline
\end{tabular}

1) For 1974

* UN Statistical affice Estimate 


\section{Table 19.1.3}

\section{Consuming Sector}

Resource

Household and Commercial

0.22

4.43

16.2

10.8

2.18

0

6.56

7.36

0

$-$

Nuclear Power (TWh)

Hydro Power (TWh)

Geothermal Power (TWh)

Utility Electricity
Distributed (TWh)
23.82

23.12

0.93
Electrical

Generation

Total

$\begin{array}{cc}0.87 & 3.27 \\ 0.75 & 19.10 \\ 10.9 & 37.9 \\ 3.87 & 3.87 \\ 0 & 0 \\ 0 & 0\end{array}$

6.04

53.91 


\section{FORZCASTS OF ANNUAL ENERGS DEMAND AND ELECTRICITY DEMAND}

Tabie 19.1 .4

\begin{tabular}{|c|c|c|c|c|c|c|}
\hline \multirow[t]{2}{*}{ Year } & \multicolumn{2}{|c|}{$\begin{array}{c}\text { Low Economic Growth } \\
3.0 \%\end{array}$} & \multicolumn{2}{|c|}{$\begin{array}{c}\text { Medium Economic Growth } \\
4.5 \%\end{array}$} & \multicolumn{2}{|c|}{$\begin{array}{c}\text { HIgh Economic Growth } \\
6.0 \%\end{array}$} \\
\hline & $\begin{array}{c}\text { Total Primar } \\
\text { Energy } \\
\left(10^{12} \text { BtU }\right)\end{array}$ & $\begin{array}{c}\text { Electricity } \\
\text { (IWh) }\end{array}$ & $\begin{array}{c}\text { Total Primary } \\
\text { Energy } \\
\left(10^{12} \text { BtU }\right)\end{array}$ & $\begin{array}{c}\text { Electricity } \\
\text { (TWh) }\end{array}$ & $\begin{array}{c}\text { Total Primary } \\
\text { Energy } \\
\left(10^{12} \text { BtU }\right)\end{array}$ & $\begin{array}{c}\text { Electric1ty } \\
(\text { TWh })\end{array}$ \\
\hline 1975 & 2,225 & 54.3 & 2,225 & 54.3 & 2,225 & 54.3 \\
\hline 1985 & 2,845 & 85.4 & 3,285 & 105.4 & 3,789 & 129.8 \\
\hline 2000 & 4,432 & 162.9 & 6,325 & 275.8 & 9,071 & 463.5 \\
\hline
\end{tabular}




\section{CONSUMPTION OF ENERGY RESOURCES}

Table 19.1 .5

\begin{tabular}{|c|c|c|c|c|c|c|c|}
\hline \multirow[t]{2}{*}{ Resource } & \multirow[t]{2}{*}{ Stancard Untt } & \multicolumn{3}{|c|}{$\begin{array}{l}\text { Annual Consumption of } \\
\text { Standard Units }\end{array}$} & \multicolumn{3}{|c|}{$\begin{array}{l}\text { Energy Consumption } \\
(1012 \mathrm{BtU})\end{array}$} \\
\hline & & 1975 & 1985 & 2000 & 1975 & 1985 & 2000 \\
\hline Coal & M1lifon Tonnes & 3.39 & 6.9 & 15.9 & 94.1 & 192 & 441 \\
\hline Crude 011 & M1111on Tonnes & 16.52 & 42.0 & 100.5 & 703.5 & 1,788 & 4,282 \\
\hline Natural Gas & Cubic $\mathrm{km}$ & 38.66 & 35.3 & 31.6 & $1,389.1$ & 1,267 & 1,137 \\
\hline Hydro Power & TWh & 0 & 0 & 0 & 0 & 0 & 0 \\
\hline Other Renewables & TWh & - & - & - & - & - & - \\
\hline Nuclear Power & TWh & 3.33 & 3.4 & 83.0 & 37.9 & 38 & 465 \\
\hline Uranium & Thousand tonnes $\mathrm{U}_{3} \mathrm{O}_{8}$ & 0 & $0.53^{\circ}$ & 1.20 & . & - & - \\
\hline
\end{tabular}


19.2 NUCLEAR HISTORY, CAPABILITY, COMMITMENT AND TRENDS

COMMERCIAL NUCLEAR POWER PLANTS

Table 19.2.1

$\begin{array}{llccccr}\begin{array}{l}\text { Facility } \\ \text { Name }\end{array} & \text { Utility } & \text { Vendor } & \begin{array}{c}\text { Facility } \\ \text { Type }\end{array} & \begin{array}{c}\text { Capacity } \\ \text { (MWe net) }\end{array} & \text { Status*... COD } \\ \text { Dodewaard } & \text { GKN } & \text { GE } & \text { BWR } & 52 & 0 & \text { Jan } 1969 \\ \text { Borssele } & \text { PZEM } & \text { KWU } & \text { PWR } & 445 & 0 & \text { Nov } 1973 \\ \text { Netherlands-3 } & \text { GKN } & - & \text { PWR } & 960 & \text { P } & 1987\end{array}$

* O-Operational; U-Under Construction; P-Planned 
Table 19.2.2

\begin{tabular}{|c|c|c|c|c|c|c|c|c|c|}
\hline Year & PWR & BWR & Magnox & AGR & CANDU & Other & FBR & $\begin{array}{l}\text { Firm }+ \\
\text { Planned } \\
\text { Cumulative } \\
\text { Total }\end{array}$ & $\begin{array}{c}\text { NAC } \\
\text { Cumulative } \\
\text { Projection }\end{array}$ \\
\hline
\end{tabular}

$\begin{array}{rrr}\text { pre-1978 } & 445 & 52 \\ 1978 & & \\ 1979 & & \\ 1980 & & \\ 1981 & & \\ 1982 & & \\ 1983 & & \\ 1984 & & \\ 1985 & & \\ 1986 & & \\ 1987 & 960 & \\ 1988 & \cdot & \\ 1989 & & \\ 1990 & & \\ 1991 & & \\ 1992 & & \\ 1993 & 650 & 650 \\ 1994 & . & \\ 1995 & & \\ 1996 & 650 & 650 \\ 1997 & & \\ 1998 & & \\ 1999 & 650 & 650 \\ 2000 & & \end{array}$

$\begin{array}{ll}497 & 497 \\ 497 & 497 \\ 497 & 497 \\ 497 & 497 \\ 497 & 497 \\ 497 & 497 \\ 497 & 497 \\ 497 & 497 \\ 497 & 497 \\ 497 & 497 \\ 1457 & 1457 \\ 1457 & 1457 \\ 1457 & 1457 \\ 1457 & 1457 \\ 1457 & 1457 \\ 1457 & 1457 \\ 1457 & 2757 \\ 1457 & 2757 \\ 1457 & 2757 \\ 1457 & 4057 \\ 1457 & 4057 \\ 1457 & 4057 \\ 1457 & 5357 \\ 1457 & 5357\end{array}$


NUCLEAR REACTOR VENDORS

Overview

Although there is no reactor vendor per se in the Netherlands, Dutch industry is closely involved in several nuclear power plant supply groups. The most long established group consists of Comprimo N.V. (an architect engineer), Rijn-Schelde-Verolme (RSV) (supplier of heavy equipment) and General Electric Co. (reactor technology). It was set up both for the anticipated domestic Dutch market and other markets, primarily in Europe. The LWR interests of Comprimo and RSV were later integrated into a group called Nucon (1/3 Comprimo, 2/3 RSV). The Nucon group has a major involvement in the nuclear portion of the Leibstadt nuclear power station under construction in Switzerland. The Nucon group, together with GE and Brown-Boveri of Switzerland, made bids to South Africa for the two Koeberg units in South Africa.

A second LWR group which was set up by Verenigde Machinefabrieken (VMF)/Stork-Werkspoor, Hollandse Beton Groep, Siemens Nederland and KWU no longer exists.

The Netherlands is closely involved in the financing, research and development and the supply of equipment for the joint DutchBelgium-German demonstration fast breeder reactor SNR-300 now under construction in Germany. The Dutch Government provides about $15 \%$ of the cost of the project via the multinational utility Schnell-Bruter-Kernkraftwerkgesellschaft, SBK (SEP, Netherlands $14.8 \%$; Synatom, Belgium 14.8\%; RWE, Germany $68.8 \%$; CEGB;UK 1.6\%): The Dutch equipment supply partner is Neratoom which consists of the major elements of the Dutch nuclear industry (RSV, VNF/Stork, Comprimo, Philips, etc.) and which is involved in coordinating and performing fast breeder industrial development and engineering for the member companies and awarding subcontracts for equipment for SNR-300. The Energleonderzock Centrum Nederland (ECN), formerly Reaktor Centrum Nederland, and TNO are involved in basic fast reactor. research and development work and there is close collaboration bctwcen industrial groups and research centers in the three countries. 
Nuclear Reactor Vendor Support Industries

As can be anticipated from the above, Dutch industry is able to supply a wide range of components and equipment for LWR's and is making rapid progress in the same direction for FBR's. For the main components the most important of these companies is Rotterdam Nuclear, RN ( $50 \%$ RSV, 50\% Dutch Government) which supplies pressure vessels. RN has the capability to produce about five large vessels per year. Facilities exist for the the forming of all sizes of plates; the only parts which must be purchased are the heavy ring forgings. Vessels are shop assembled since transport from the factory is not limited (except where parts of vessels are supplied to other vessel manufacturers e.g., to Sulzer for Leibstadt). Some 25 vessels have been delivered so far.

In view of the depressed nuclear market and extensive competition, in 1977, RN concluded negotiations with the government of Netherlands for $50 \%$ participation and a large interestfree loan. $\mathrm{RN}$ also expanded its activities to include the petro-chemical, chemical and coal conversion markets. The plan is to devote $50 \%$ of its activities to nuclear and the other half to the other areas. To acknowledge these changes, the company's name was changed to Rotterdam Heavy Equipment $(\mathrm{RSV}-\mathrm{A})$. 
NUCLEAR FUEL CYCLE FACILITIES

\section{Overview}

The Netherlands has had a fairly wide involvement in the nuclear fuel cycle.

In 1967/68 Philips fabricated the first core of the Dodewaard BWR. However, because of the lack of a market they withdrew from the business. In 1972 a new fuel fabrication company, Interfuel, was set up by Dutch industry with the aim of taking advantage of processes developed at the ECN for the production of either pelletized or vibrocompacted oxide fuel (including mixed oxides) obtained from the sol-gel process. In 1975, the lack of both a domestic and foreign market also led to the withdrawa 1 of interfuel from the marker.

Gas centrifuge enrichment has been under study and development at ECN since the late $1950^{\prime} s$. In 1969, Ultra Centrifuge Nederland N.V. (UCN) was set up to represent Dutch interests in the tripartite agreement with Germany and the UK for centrifuge enrichment activities. UCN is owned $55 \%$ by the Dutch Government chrough ECN and 45\% by Dutch indugtry (10\% Philipe Gloellampenfabrieken NV; $10 \%$ Shell Kernenergie NV; $10 \%$ Staatsmijen; $7.5 \%$ Rijn-Schelde NF; 7.5\% Verenigde Machinefabrieken NV). UCN, BNFL (UK) and Uranit (Germany) each have a one-third share in Urenco Ltd. with headquarters in the UK which has the responsibility to purchase and operate centrifuge enrichment plants and market the output. Pilot and production facilities exist both at Capenhurst (UK) and Almelo (Netherlands). UCN, BNFL and GnV (Germany) also each have a one-third share in CENTEC (Gesel1schaft fur Zentrifugentechnik mbH) with headquarters in Germany which has the responsibility for the design, development and manufacture of plants.

Recently, Dutch industry has expressed concern about continuing involvement in UCN due to uncertain market conditions. Although there has been no firm announcement by the Government, it is believed that the Netherlands intends to remain a full partner in Urenco and CENTEC. Current enrichment facilities in the Netherlands are summarized in Table 19.2.3. The details of operation, capacity and capacity expansion plans, markelluy slıalegy, market sharco and production are givell under Urenco, United Kingdom.

RCN also has a small shareholding in the international Eurochemic reprocessing plant in Belgium which was closed down in 1974. 


\section{CURRENT FACILITIES}

Table 19.2.3

\begin{tabular}{|c|c|c|c|c|c|c|}
\hline $\begin{array}{c}\text { Facility } \\
\text { Name }\end{array}$ & Location & $\begin{array}{c}\text { Facility } \\
\text { Type }\end{array}$ & \multicolumn{3}{|c|}{ Capacity Status } & Shareholdings \\
\hline $\begin{array}{l}\text { Almelo } \\
\text { Pilot Plant SP1 }\end{array}$ & Almelo & $\begin{array}{l}\text { Centrifuge } \\
\text { Enrichment }\end{array}$ & $\begin{array}{c}20 \\
(25 \text { nominal) }\end{array}$ & 0 & 19.74 & $100 \%$ Urenco \\
\hline $\begin{array}{l}\text { Almelo } \\
\text { Pilot Plant SP2 }\end{array}$ & Almelo & $\begin{array}{l}\text { Centrifuge } \\
\text { Enrichment }\end{array}$ & 25 & 0 & 1974 & $100 \%$ Urenco \\
\hline $\begin{array}{l}\text { Centrifuge Manufacturing } \\
\text { Facility }\end{array}$ & Almelo & - & - & 0 & & $100 \%$ UCN \\
\hline
\end{tabular}

* 0-Operationa1; U-Under Construction; P-Planned 
Vested Interests in Current Fuel Cycles and Reactor Technologies

The Netherlands has a significant vested interest in both current and future reactor technologies and fuel cycles.

Both the Government and industrial companies are deeply involved in the continuing development of know-how and the supply of equipment and components for both LWR's and FBR's. Rotterdam Nuclear in particular possesses extensive pressure vessel manufacturing capabilities.

There also exists a major national vested interest in centrifuge uranium enrichment through the participation of 1ndustry and Government in Urenco and GENTEC. Urenco is dullelpaled ló becoilie nne of the important future suppliers of enrichment since centrifuge plants unlike diffusion plants can be step-wise expanded to meer marker requirements,

Current 'Irends in Nuclear Development Programs

Despite the uncertainty in both domestic and export nuclear markets, the Netherlands is continuing to maintain and develop through industry and Governmental actions an active LWR support industry including both the supply of components and equipment and enrichment services. There are, however, some doubts at this time as to the future position, particularly of Dutch industry in enrichment. Further, FBR development and supply is bcing activcly puroucd. 


\subsection{NUCLEAR TECHNOLOGY CAPABILITY AND RESOURCES}

PROFESS IONAL LABOR FORCE PROFILE

Table 19.3.1

Information available shows that in 1973, there were 22,554 Scientists and Engineers engaged in $\mathrm{R} \& \mathrm{D}$.

KEY TECHNICAL EDUCATIONAL RESOURCES

Table 19.3.2

Institution

Location

Universiteit van Amsterdam

Amsterdam

V.rije Universiteit te Amsterdam

Amsterdam

Technische Hogeschool te Delft

Delft

Technische Hogeschool te Eindhouen

Eindhouen

Technische Hogeschool Twente

Enschede

Rijksuniversiteit te Groningen

Groningen

Rijksuniversiteit te Leiden

Leiden

Katholieke Universiteit te Nijmegen

Nijmegen

Erasmus Universiteit Rotterdam

Rotterdam

Katholieke Hogeschool te Tilburg

Tilburg

Rijksuniversiteit te Utrecht

Utrecht 


\section{KEY GOVERNMENTAL NUCLEAR RESEARCH ORGANIZATIONS}

Table 19.3 .3

Name

Netherlands Organization of Technical and Scientific Research (TNO)

Netherlands Energy Development Company (NEDM)
Location

The Hague

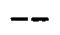

The Hague

\section{Main Activities}

implements along with ECN national energy $R \& D$ programs

helps to improve country's energy pusition by undertaking or assisting industry to undertake new energy development progress.

responsible for management of fundamental. research

nuclear research and development. Took over responsibilities of the Reactor Centrum Nederland (KCN) and the Central Organization for Applied Research (NND)

makes recommendations for energy research including nuclear energy 


\section{KEY PRIVATE - NUCLEAR RESEARCH ORGANIZATIONS}

\section{Table 19.3.4}

Name

Neratoom

Owner

(cooperative with Dutch Philips Company)

AKZO B.U.

Verenigde Machini Fabrieken

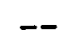

Rhine Schelde Verolme

Engineers \& Shipbuilders

U1tra-Centrifuge Nederland

N.V.
Arnhem

Amsterdam

Rotterdam

\section{Location}

The Hague

The Hague

\section{Main Activities}

breeder reactor research

waste storage \& disposal ultracentrifuge, LMFBR design

fuel rod development LMFBR design waste storage \& disposal

uranium enrichment

Much of laboratory scale research is carried out by government sponsored research organizations as ECN \& TNO. Industry is represented on the boards and in the advisory councils of these institutions, where the research programs and projects are discussed and decided. In the nuclear field, where nost of the work is in the development and even demonstration phase, much work has been carried out by industry in close cooperation with ECN and TNO. 
RESEARCH AND TEST REACTORS

List of Reactors

Tabli 19.3 .5

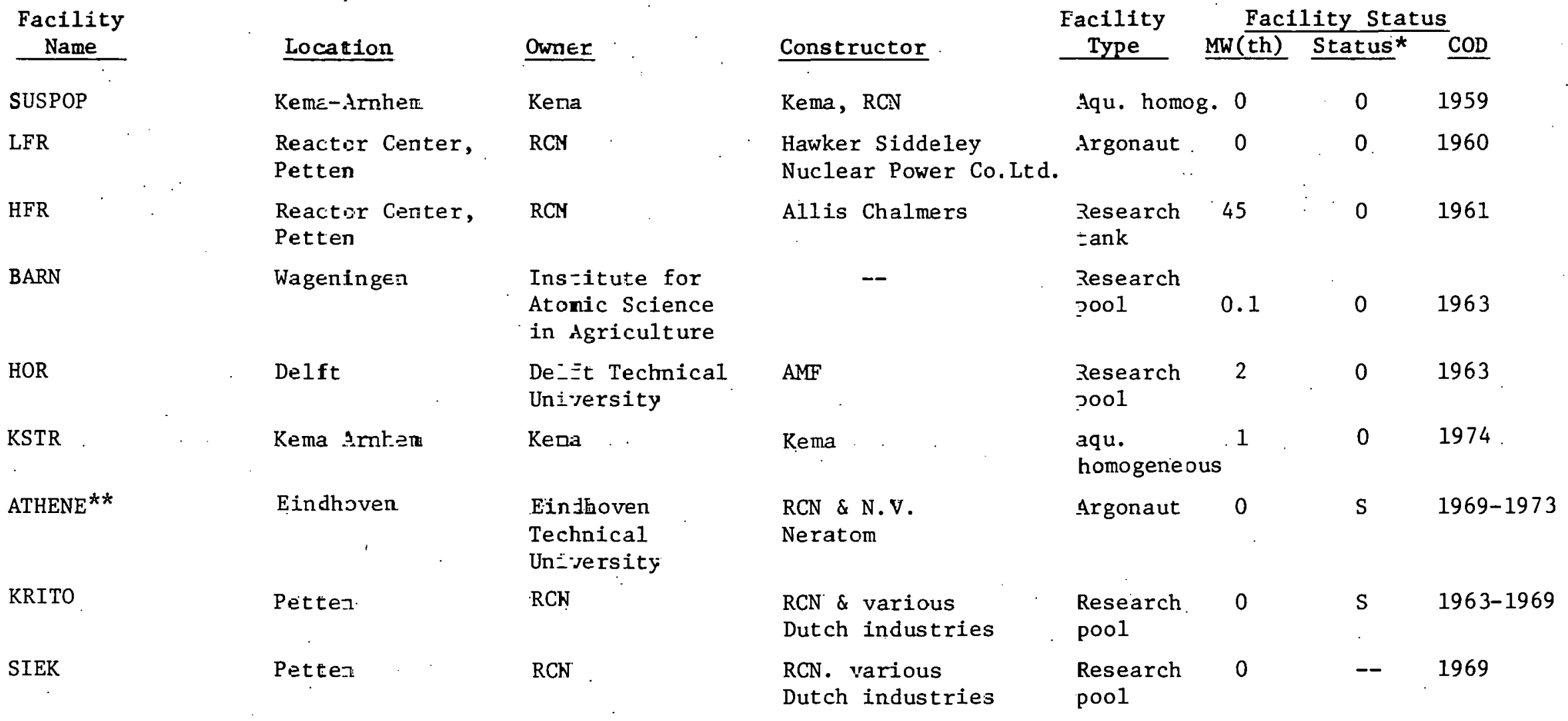

* O-Operational; U-Under Construction; P-ב-annec; S-Shutdown

** Decommissioned 


\section{INDIGENOUS CAPABILITY TO DESIGN AND SUPPLY RESEARCH AND TEST REACTORS AND FUEL SERVICES}

\section{Summary of Reactor Orders by Vendor and Country}

Table 19.3.6

\begin{tabular}{|c|c|c|c|c|c|c|c|}
\hline & & Facility & Facility & \multicolumn{3}{|c|}{ Facility Status } & \multirow{2}{*}{$\begin{array}{l}\text { Scope of } \\
\text { Services }\end{array}$} \\
\hline Vendor & Country & Name & Type & $\mathrm{MW}(\mathrm{th})$ & Status* & $\mathrm{COD}$ & \\
\hline V. Neratoom & Italy & $\begin{array}{c}\text { ECO } \\
\vdots\end{array}$ & $\begin{array}{l}\text { tank, nat. } \mathrm{U} \text {, } \\
\mathrm{D}_{2} \mathrm{O} \text {, organic }\end{array}$ & 0 & $\mathrm{~S}$ & $1965-1972$ & Constructor \\
\hline ema & Netherlands & SUSPOP & Aqu. Homog. & 0 & 0 & 1959 & Constructor \\
\hline $\begin{array}{l}\mathrm{CN}+ \\
\text {. V. Neratoom }\end{array}$ & Netherlands & Athene** & Argonaut & 0 & $\mathrm{~S}$ & $1969-1973$ & Constructor \\
\hline $\mathrm{CN}$ & Netherlands & KRITO & Pool & 0 & $S$ & $1963-1969$ & Constructor \\
\hline $\mathrm{CN}$ & Netherlands & SIEK & Pool & 0 & - & 1969. & Constructor \\
\hline
\end{tabular}

* O-Operational; U-Under Construction; P-Planned; S-Shutdown

** Decommissioned 
SUMMARY OF FUEL S.ERVICES FOR RESEARCH AND TEST REE.CTORS

Table 19.3.7

Facility

Name

Facility
Lycation

$\frac{\text { Capacity Status }}{\underline{\text { MR/YR }} \text { Status* } \underline{\text { gear }}}$

Shareholdings

CERCA and NUKEM are fabricating the fuel elements fcr nuclear research reactors and MIR'S. The reactors are owned by EURATOM and there is an agreement for the fabrication of the fuel.

* O-Operational; I-Under Construction; P-Planned; S-Shutdown 
19.4 ECONOMIC RESOURCES FOR NUCLEAR POWER DEVELOPMENT

ECONOMIC DATA PROFILE

$\underline{\text { Table } 19.4 .1}$

$\begin{array}{llll}\text { GNP (Current million \$) } & -105,600(1977) & \text { Inflation Rate } & -4.8 \%(1978) \\ \text { Exports (million \$) } & -40,200(1977) & \text { Imports (million \$) } & -39,500(1977) \\ \text { Per Capita Income (\$) } & -7,597(1977) & \text { Disposable Income (\$) }-5,303(1975) \\ \text { Monetary Unit } & - \text { Guilders } & \text { Exchange Rate (/US\$) }-2.45(4 / 77) \\ \text { Population (million) } & -13.9(1978) & \end{array}$

19.4.2 GOVERNMENTAL NUCLEAR ENERGY R\&D BUDGET

\begin{tabular}{|c|c|}
\hline & $\begin{array}{c}\text { MILLIONS } \\
1977 \\
\end{array}$ \\
\hline $\begin{array}{l}\text { NUCLEAR FISSION } \\
\text { LWR } \\
\text { HTR } \\
\text { Other Converter Reactors } \\
\text { Fuel Cycle }\end{array}$ & $\begin{array}{r}48.5 \\
(12.6) \\
(2.3) \\
(2.3) \\
(30.2)\end{array}$ \\
\hline FAST BREEDER & 30.2 \\
\hline NUCLEAR FUSION & 12.9 \\
\hline $\begin{array}{l}\text { SUPPORTING TECHNOLOGIES } \\
\text { Electric Power Conversion } \\
\text { Transmission and Distribution } \\
\text { Energy Storage. } \\
\text { Energy Systems Analysis } \\
\text { Others }\end{array}$ & $\begin{array}{l}15.4 \\
(4.6) \\
(0.9) \\
(1.6) \\
(4.6) \\
(4.3)\end{array}$ \\
\hline
\end{tabular}


GOVERNMENTAL SUPPORTED NUCLEAR R\&D INDUSTRY, UNIVERSITIES

AND NATIONAL LABORATORIES

Table 19.4 .3

\section{Industry \\ University or \\ Laboratory}

Netherlands Energy Center $(\mathrm{ECN})$

Central Terhnical
Inotituto
Foundation for Fundamencal
Research on Matter (FOM)

Central Laboratory

Electronic Materials Testing Company (KEMA)

\section{ERASMUS University \\ Institute for Nuclear Physics Research (IKO) \\ University of Amsterdam \\ Institute for the App1ication of Nuclear Energy in Agriculture (ITAL)}

Delft Reactor Institute (RID)

Tilburg University
Program
Area

Nuclear marine propulsion, reactor kinetic experiments, fast breeder research

Sodium coolant in fast reartors

Nucledr pliysics, mass separation and analysis, thermonuclear reactions research and high energy physles

\section{Isotope research}

Aqueous homogeneous suspension reactors with circulating liquid fuel

LMFBR design

Nuclear reactions, nuclear spectroscopy, radiochemistry

Ultra-Centrifuge

Radiation-caused mutations in plants, preservation of foodsculfs by linadialiun, behavior of isotopes and labeled compounds in the nutrition cycle in the soil as well as plants and animals, use of radioactive substances in blological research

Dynamic behavior of a pressurized system for a high-pressure water reactor

Fuel rod production and development
Budget \$ (Milllons)

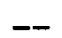

Dr. E. Kramer

Key Personnel
8.3

-- W. K. Wierchers
Dr. J. A. Bourdrez

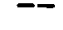

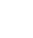


GOVERNMENTAL SUPPORTED NUCLEAR R\&D INDUSTRY, UNIVERSITIES

AND NATIONAL LABORATORIES

Table 19.4.3 (Cont.)

Industry

University or

Laboratory

Institute of Radiopathology and Radiation Shielding

Laboratory for Heat Technology and Reactor

Engineering
Program Area

Radioactive isotopes and ionizing radiation

Heat transfer and hydraulics of gascooled reactors
Budget

\$ (Millions) Personnel
Key $-$ 


\subsubsection{ROLE OF PRIVATE INDUSTRY IN NUCLEAR ENERGY R\&D}

Energy $R \& D$ expenditures for industry in 1977 are expected to be $\$ 54.1$ million, as compared to the Government energy R\&D budget of $\$ 137.5$ million. Over the last four years industrial investment in energy $R$, $D \& D$ has increased five to six fold and expanded its share to technology to $60 \%$ of the total industrial investment in 1977, while that of nuclear fission continued to decline slightly in absolute terms. Future prospects of industrial investment up to 1985 are expected to be very slow with relatively high increases in renewable resources and conservation technologies.

Dutch industry plays an increasingly important role in demonstration projects. The Netherlands Energy Development Company (NEOM) was created in 1976 to assist industry in bringing new energy technologies to commercial use.

The major impediments in the way of enhancing industrial $K$, $U \& D$ activities and commercial application are:

1. a general shortage of funds;

2. uncertainty about the energy policy of the Government;

3. a general shortage of qualified staff.

ECONOMIC PROFILE OF REACTOR VENDORS AND FUEL CYCLE FACILITIES

Table 19.4.5

Name

Sharo Capital

Assets

Sales

Ultra Centrifuge

Nederland N, V. (UCN)

(Owned 55\% Government.

and $15 \%$ inductry)

19.4.6 MODE OF FINANCING OF NUCLEAR POWER PLANTS

Dutch reactors were obtained from G.E. and KWII. 
19.5 GOVERNMENT COMMITMENT AND ROLE IN NUCLEAR POWER DEVELOPMENT

\subsubsection{ENERGY POLICY - BASIC LEGISLATION}

1. Netherlands Oil Company (NAM) established in 1947.

2. Nuclear Energy Act 1963.

3. Gasonie, the sole natural gas distributing company in the Netherlands, established 1963 .

4. Interdepartmental Commission for Nuclear Energy founded in 1964 to coordinate policies regarding peaceful nuclear application.

5. Surface Water Pollution Act 1970.

6. Air Pollution Act 1972.

7. The National Steering Committee for Energy Research (LSEO) established 1974 .

8. Netherlands Energy Center (ECN) established 1976, taking over the responsibilities of the Reactor Centrum Nederland (RCN) and the Central Organization for Applied Research (NND). The Center will handle nuclear $R \& D$, as well as more exotic energy research projects.

9. In 1976, Parliament approved the principles of the government's energy White Paper published in 1974.

10. Netherlands Energy Development Company (NEOM) established 1976.

11. Fast Breeder Act.

In the area of energy conservation, legislation is in preparation which may lead to increased efforts to develop energy saving technologies. 


\subsubsection{GOVERNMENTAL STRUCTURE FOR NUCLEAR ENERGY POLICY AND R\&D}

LEGISLATIVE - a bicameral Parliament called the States General consists of the First Chamber (upper house composed of 75 members) and the Second Chamber (lower house composed of 150 members). The two chambers meet separately, except for ceremonial occasions. In addition to their legislative authority, both chambers exercise a check on the Council of Ministers through questioning and investigation. The First Chamber mainly reviews legislation passed by the Second Chamber. The Second Chamber, however, is far more important, for it alone has the right to initiate legislation and amend bills submitted by the Council of Ministers. Both chambers have committees that consider energy matters. For example, the Second Chamber has a standing committee on nuclear energy, however, most energy questions are brought up in the Economics Commit.tee.

EXECUTIVE - the Council of Ministers (or Cabinet) has collective responsibility. The President of the Council (Prime Minister Andreas A. M. van Agt) cannot over-ride the majority of his colleagues, although he exerc1ses. significant influence on decisions.

The Minister of Economic Affatrs (G1jsbert M. V. van Aardenne) is respunsible for the establishment and implementation of energy policy and energy R\&D policy.

\section{OTHER PARTS OF THE ENERGY STRUCTURE}

1. Minister for Science Policy (Rinus W. J. M. Peijnenburg) deliberates with the Minister of Economic Affairs to ensure that the energy R\&D policy, envisioned by the latter, fits in general science policy of the Government.

2. General Energy Council (AER), which is broad in scope, advises the Minister of Economic Affairs on matters regarding energy policy.

3. National Energy Research Steering Committee (LSEO) is constituted of recognized experts with mainly a research background and advises both the Minister of Science Policy and Minister of Economic Affairs on matters regarding energy $R \& D$ policy.

4. Netherlands Energy Research Foundation (ECN) and, to a lesser extent, the Netherlands Organization of Technical and Scientific Research (TNO) are the agencies through which the energy $R \& D$. program is implemented.

5. Energy Research Council (REO) is expected to replace LSEO by the end of 1977 .

6. Netherlands Energy Development Company (NEOM) is state-owned with an objective of helping to improve the national energy position by undertaking or by assisting industry to undertake new energy development projects that are not yet commercialiy attractive.

7. While nuclear activities are conducted cooperatively by various organizations and institutions (Government-subsidized to varying degrees), as well as the universities and energy producers, the Interdepartmental Commission for Nuclear Energy is responsible for coordinating policies regarding peaceful nuclear application. 
19.5.3 ORGANIZATION FOR IMPLEMENTATION OF NUCLEAR ENERGY POLICY AND R\&D

MINISTRY OF ECONOMIC AFFAIRS (Minister, Gijsbert M. V. van Aardenne)

DIRECTORATE GENERAL FOR ENERGY SUPPLY - divided into five directorates of which four provide advice on energy policy and legislation in the specific fields of:

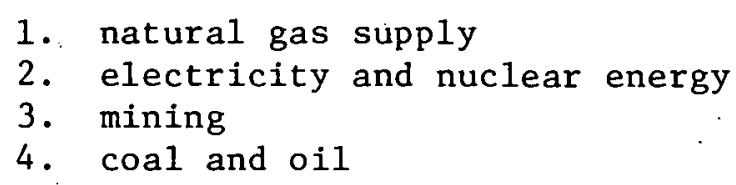

The fifth directorate advises the Cabinet on international energy affairs, in particular, those related to EEC and OECD, and on matters related to energy R\&D policies.

Scenarios and other relevant policy information are supplied by:

1. Energy Study Center (technological information)

2. Central Planning Bureau (for economic data)

\subsubsection{NUCLEAR ENERGY POLICY AND OBJECTIVES}

A coalition government was formed in December 1977 , and is not yet in a position to take firm control of the nuclear siting and disposal waste debate now underway. The country is resting on its still adequate sources of gas and oil, but is dependant on imports of $90 \%$ of its energy demands. The present government is not showing signs of being anti-nuclear as it decided to allow the expansion of the Urenco enrichment plant at Almelo and is considering how best to develop the nuclear industry (not whether to develop it). 


\subsubsection{NUCLEAR ENERGY R\&D - STATUS AND OUTLOOK}

The Netherlands has two nuclear power reactors with a total output of $500 \mathrm{MWe}$, and an enrichment contract for an additional reactor of 960 MWe. However, owing to various difficulties including political opposition, completion of this reactor before 1990 is questionable. There are three main areas of research in process: reactor safety, the disposal of radioactive material and enrichment. The Netherlands is participating in several international programs on uranium and plutonium analyses. for safeguarding purposes. Cooperation was set up with UK and FRG to develop the ultra-centrifuge technology. Three pilot plants with a capacity of 20 tonnes SWU per annum are in operation, and under construction are two demonstrating plants of 200 tonnes SWU/year, one at Almelo. The Netherlands is cooperating with FRG and Belgium on the development of a 300 MWe sodium cooled fast breeder reactor, the 3Pr-300). The Dutch effort is the development of the large components in the heat-exchange system as well as the building and operation of a 50MW testbed for sodium components. For the time being, the Dutch Government has decided not to participate in the construction of a commercial scale fast breeder reactor, SNR-2. The Dutch participate in thermonuclear fusion research wi.thin the framework of EURATOM. 


\subsubsection{NUCLEAR ENERGY R\&D - PRIORITIES}

The following areas of R\&D priority have been established:

\section{CATEGORIES}

Proven Reactors

HTGR

Breeders

Fue1 Cycle

Waste Treatment \& Disposal

Safety

Transportation
AREA OF $R \& D$

- Reactor studies and calculations

- Fuel behavior experiments

- Steam boilers

- Pressure vesse1

- Assessment

- Graphite irradiation and research

- Coated particle fuel behavior research

- Sodium Cooled FBR

- Components

- Fue1 behavior and safety

- Prototype kalkar

- Fabrication experiments

- Pilot plant

- Ultra centrifuge technology

- Assessment in salt formation

- Pressure vessel fracture

- Mechanics

- Reactor building response analysis

- Risk analysis

- Radioisotope toxicity and neutron radiation experiments

\subsubsection{ROI.F. OF GOVERNMENT IN NUCLEAR FACILITIES CONSTRUCTION AND OPERATION}

The government seeks approval from National Assembly for construction of power plants, and once granted, these plants are operated by the utilities. However, the state governments exercise control over normal operations of the plants. 
19.6 NON-NUCLEAR ENERGY FACILITIES AND FUEL SUPPLY

NETHERLANDS - 30 
ENERGY GENERATION FACILITIES IN EXISTENCE AND FIRMLY PLANNED PRODUCING 100 MWe (net)

Table 19.6.1

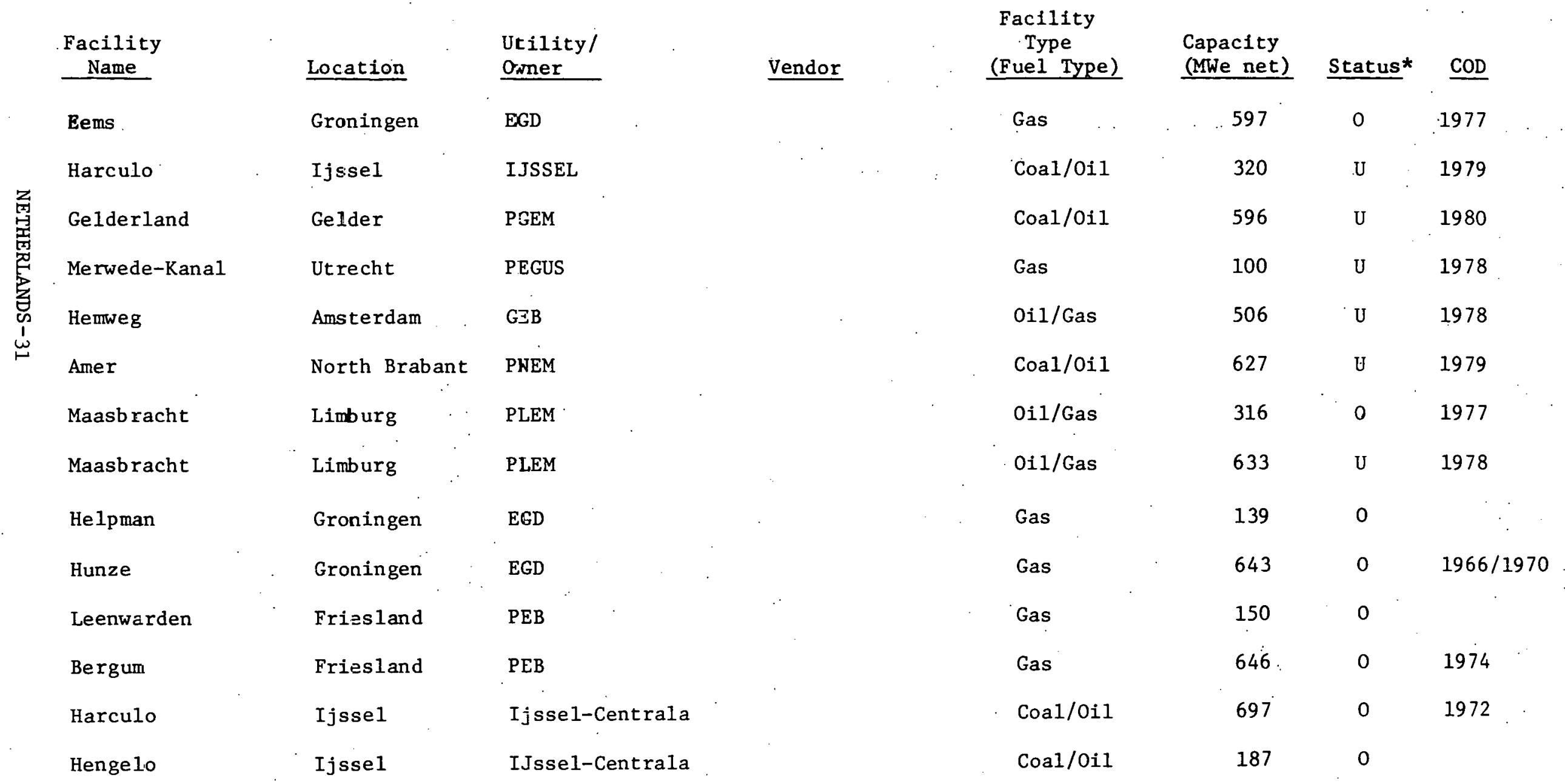

* O-Operational; U-Under Construction; P-Planned; S-Shutdown 
ENERGY GEIERATION FACILITIES IN EXISTENCE AND FIRMLY PLANNED PRODUCING 100 MWe (net)

Table 19.6.1 (Continued)

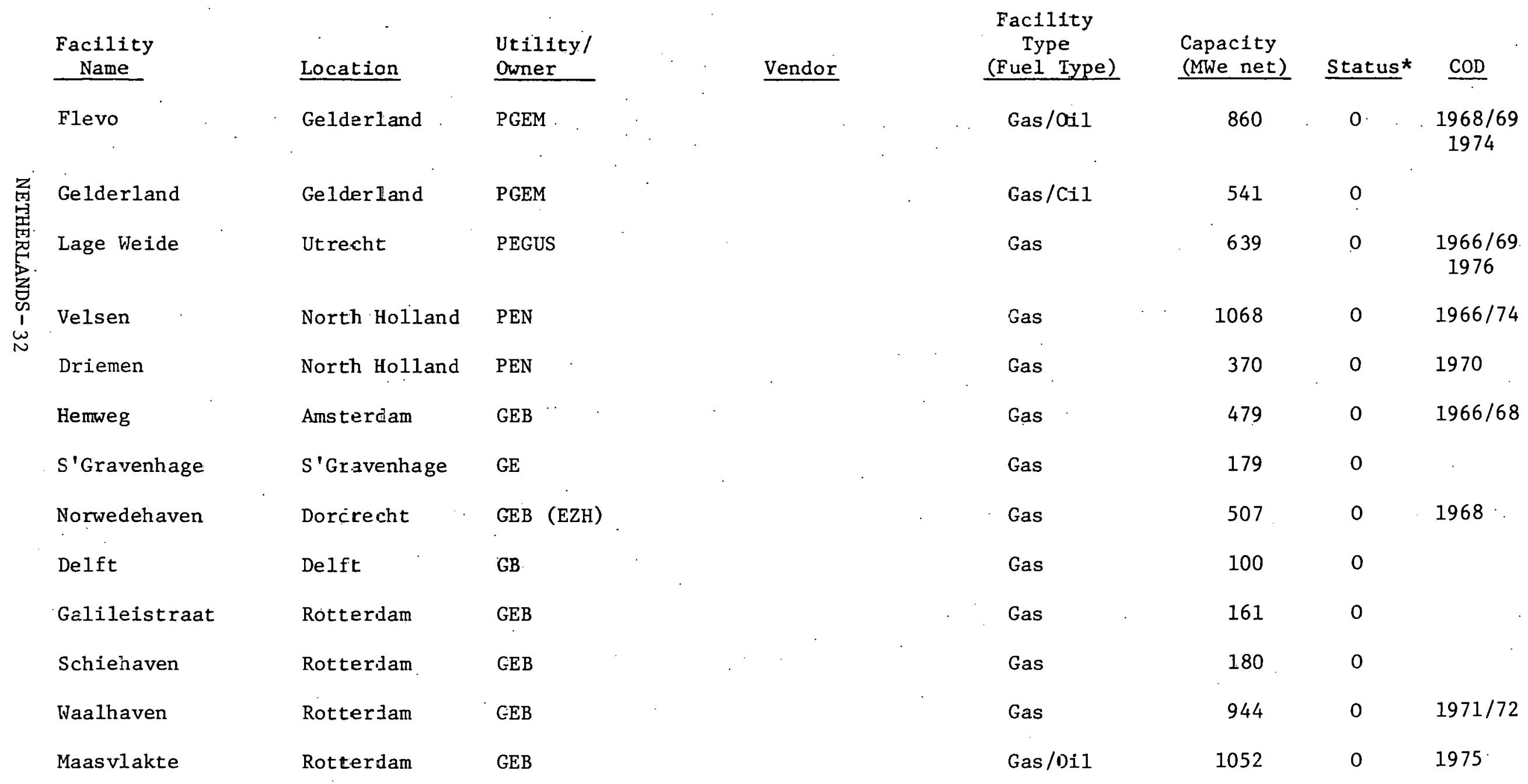

* O-Operational; U-Under Construction; P-Planred; S-Shutdown 


\section{ENERGY GENERATION FACILITIES IN EXISTENCE AND FIRMLY PLANNED PRODUCING 100 MWe (net)}

Table 19.6.1

\begin{tabular}{|c|c|c|c|c|c|c|c|}
\hline $\begin{array}{l}\text { Facillty } \\
\text { Name }\end{array}$ & Location & $\begin{array}{l}U: 11 \text { ity/ } \\
\text { Owner }\end{array}$ & Vendor & $\begin{array}{c}\text { Fac1lity } \\
\text { Type } \\
\text { (Fue1 Type) } \\
\end{array}$ & $\begin{array}{l}\text { Capacity } \\
\text { (NWe net) }\end{array}$ & Status* & $\underline{\text { COD }}$ \\
\hline Maas centrale & $\begin{array}{l}\text { Buggenum } \\
\text { (Limburg) }\end{array}$ & PLEM & & $0 i 1 / G a s$ & 719 & 0 & $1966 / 69$ \\
\hline Jlissingen & Zeeland & PZEM & & Gas & 262 & 0 & \\
\hline Borssele & Zeeland & PZEM & & $\begin{array}{l}\text { 384 MW Oil/Gas } \\
\text { 443. MW Nuclear }\end{array}$ & 827 & 0 & $\begin{array}{c}1971 / 73 \\
1975\end{array}$ \\
\hline fmer & North Brabant & PNEM & & Coal/oil & 1690 & 0 & $\begin{array}{l}1966 / 71 \\
1972\end{array}$ \\
\hline Longe & North Brabant & PNEM & & $\begin{array}{c}\text { Oil/Gas } \\
\text { (Combined cycle) }\end{array}$ & 116 & 0 & \\
\hline
\end{tabular}

* O-Operational; U-Under Construction; P-Planned; S-Shutdown 
Table 19.6 .2

$\begin{array}{lc}\text { Year } & \text { Capacity - MWe (net) } \\ 1975 & 13,982 \\ 1980 & 18,045 \\ 1985 \\ 1990 \\ 1995 \\ 2000\end{array}$


LISTING OF FUEL SUPPLY FACILITIES IN EXISTENCE AND FIRMLY PLANNED

Table 19.6.3

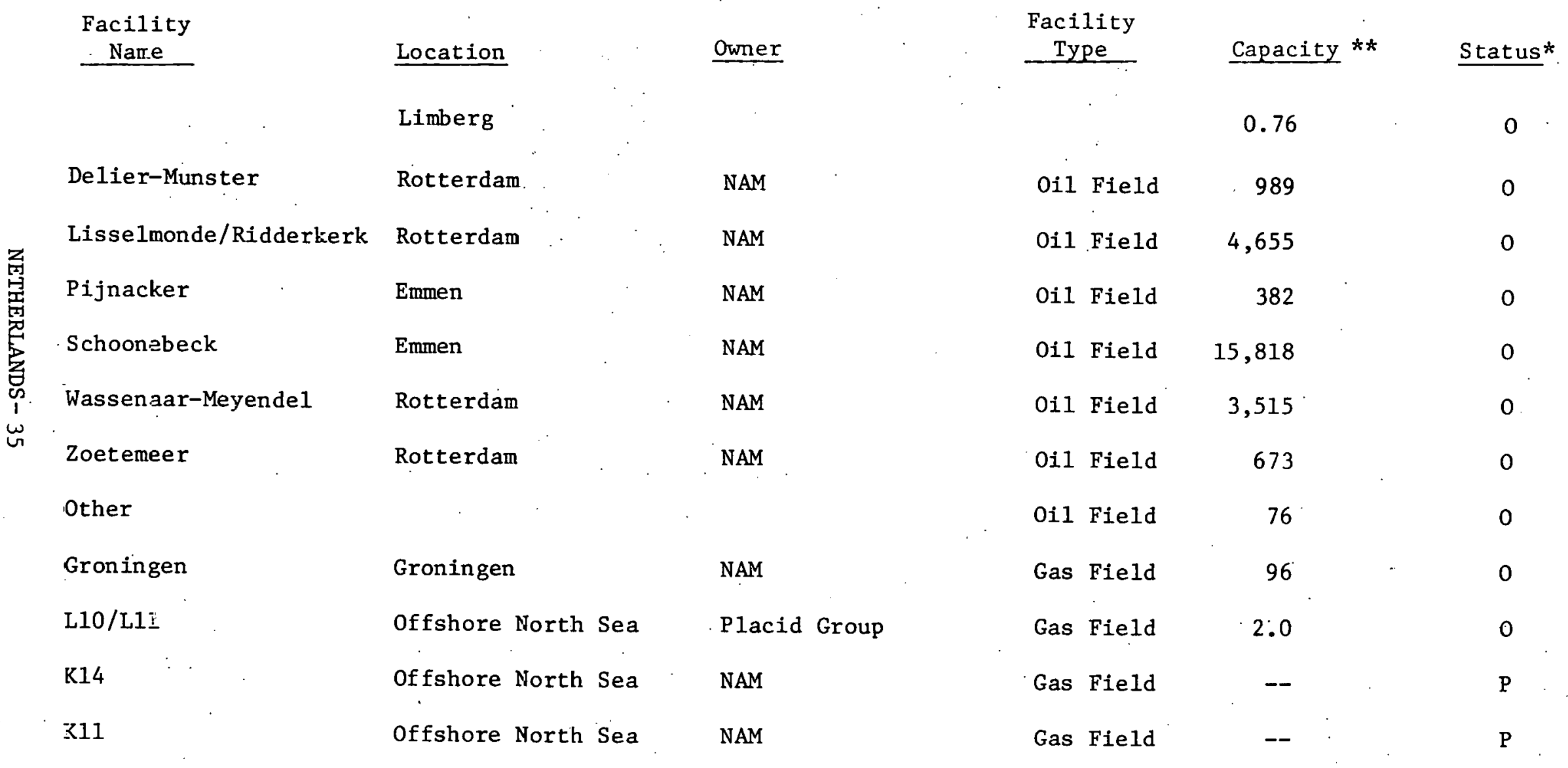

* 0-Operationa1; U-Under Corstruction; P-P1anned; S-Shutdown ** Oil-barrels/day; Natural gas- $\mathrm{km}^{3} /$ year 
Table 19.6 .4

\section{RESOURCE}

COAL (million tonnes) Indigenous Supply Imports

Exports

CRUDE OIL (million tonnes) Indigcnous Eupply

Iupuits

Exports

SHALE OIL (million tonnes)

Indigenous Supply

Imports

Exports

NATURAL GAS (cubic kilometers)

Indigenous Supply

Imports

Exports

URANIUM (kilotonnes $\mathrm{U}_{3} \mathrm{O}_{8}$ )

Indigenous Supply

Imports

Exports
1985

2000

0.72

6.18

0.38

15.52

--

1.10
10.90

0.199

.100 .41

0

0
86.42

51.12

0

.53

0
23.48

8.12

$--$

0

1. 20

0 
SECTION 20

PAKISTAN 


\subsection{PROJECTED INDIGENOUS ENERGY RESOURCES, DEMANDS AND RELATED INFORMATION}

\section{INDIGENOUS RESOURCES}

The coal reserves of Pakistan are lignites, have high moisture, ash and sulphur content and are usually non-coking and susceptible to spontaneous combustion. There are also sub-bituminous deposits of very poor quality. Neither can be transported over long distances. Indigenous resources are put at 653 million tonnes (ref. 1.2), 482 million tonnes (ref. 1.9) and 476 million tonnes (ref. 1.27). Previous estimates (ref. 1.13) put total resources as high as 1,941 million tonnes in 1966.

Pakistan has a small amount of oil, estimated at 24.5 million tonnes of which 5.3 million tonnes is economically recoverable at present. The International Encyclopedia 1isted oil reserves as 10 million tonnes. Despite a considerable investment sum (762 million Rs) during 1955-1965 no new oil deposits had been discovered until Dhodak in December 1976. Studies have put the total recoverable potential for oil as high as 4,930 million tonnes (ref. 1.27) but no confirmation of this figure has been obtained.

No figures are available for shale oil deposits.

Some good reserves of natural gas are available and the fields are almost entirely located within an 80 -mile radius of Sukkur, in the Upper Sind region. Total resources are given as $445 \mathrm{~km}^{3}$ (ref. 1.2), $521 \mathrm{~km}^{3}$ (ref. 1.9) and $419 \mathrm{~km}^{3}$ (ref. 1.27).

Al1 the hydro-electric power is connected with the River Indus and its tributaries. High seasonal variation of flow occurs together with high siltation rates. More importantly, use of water from the reservoirs for irrigation has absolute priority over the use of power. Most potential sites are situated in inaccessible regions far from load centers and therefore are not favorable for early development. The figures for hydro-power have been taken from the World Energy Conference Survey (ref. 1.2).

Small deposits of uranium are known to exist, but the magnitude is not known.

\section{ENERGY SUPPLY}

Production figures for solid fuels in Pakistan vary from 1.1 million tonnes (rcf. 1.5), 1.29 million tonnes (ref. 1.2) to 1.5 million tonnes (Paper XXXV, ref. 1.23) though the 1atter was for 1972. Reference 1.27 gives 0.921 million tonnes based on an average calorific value for coal of $1.0,000 \mathrm{Btu} / \mathrm{lb}$. Imports of hard coal are small at 0.074 million tonnes. 
Crude oil production is estimated at 0.385 million tonnes (ref. 1.5). Reference 1.2 gives 0.5 million tonnes for 1972. Reference 1.25 gives 0.39 million tonnes for 1974.

Natural gas production is estimated at $5 \mathrm{~km}^{3}$ (ref. 1.5). Reference 1.2 gives $3.97 \mathrm{~km}^{3}$ for 1972 and reference $1.254 .66 \mathrm{~km}^{3}$ for 1974 .

Small quantities of uranium are believed to be produced.

\section{PATTERNS OF ENERGY USE}

Reliable data on end uses of energy are not available according to the Government of Pakistan (see Paper XXXV, ref. 1.23). Figures for Table 20.1.3 were supplied by private communication.

\section{FORECASTS OF ENERGY SUPPLY AND DEMAND}

Total primary energy demand in Pakistan is expected to increase from its 1975 level of $399 \times 10^{12} \mathrm{Btu}$ to between $1,000 \times 10^{12} \mathrm{Btu}$ and $5,100 \times 10^{12}$ Btu by 2000 , an average annual rate of growth of $3.9 \%$ to $10.7 \%$. Electricity demand is expected to grow at an average annual rate of $4.6 \%$ to $11.8 \%$ during the same period increasing to as much as 155 TWh by 2000 . These forecasts are presented in Table 20.1.4. In the period 1965 to 1974 economic growth averaged $5.4 \%$ (ref. 1.43) while energy and electricity consumption increased by $5.3 \%$ and $8.3 \%$ per year respectively (refs. 1.5 and 1.44 ).

An energy and electricity demand forecast made by the International Atomic knergy Agency (ref. 1.19) estimated demands by 2000 of approximately 3,700 $x 1012$ Btu of primary energy and $117 \mathrm{TWh}$ of electric1cy. These furecusts, which are based on an economic growth of $4.3 \%$ per year, compare favorably with the figures shown in Table 20.1.4.

The future breakdown of energy demand into sources of supply shown in Table 20.1.5 is based on a projection of current trends such as the increasing importance of nuclear power and the reduction in the relative contribution of oil and gas. These figures are corroborated by similar values in the breakdown presented in the IAEA report (ref. 1.9). 


\section{INDIGENOUS ENERGY RESOURCES}

Table 20.1.1

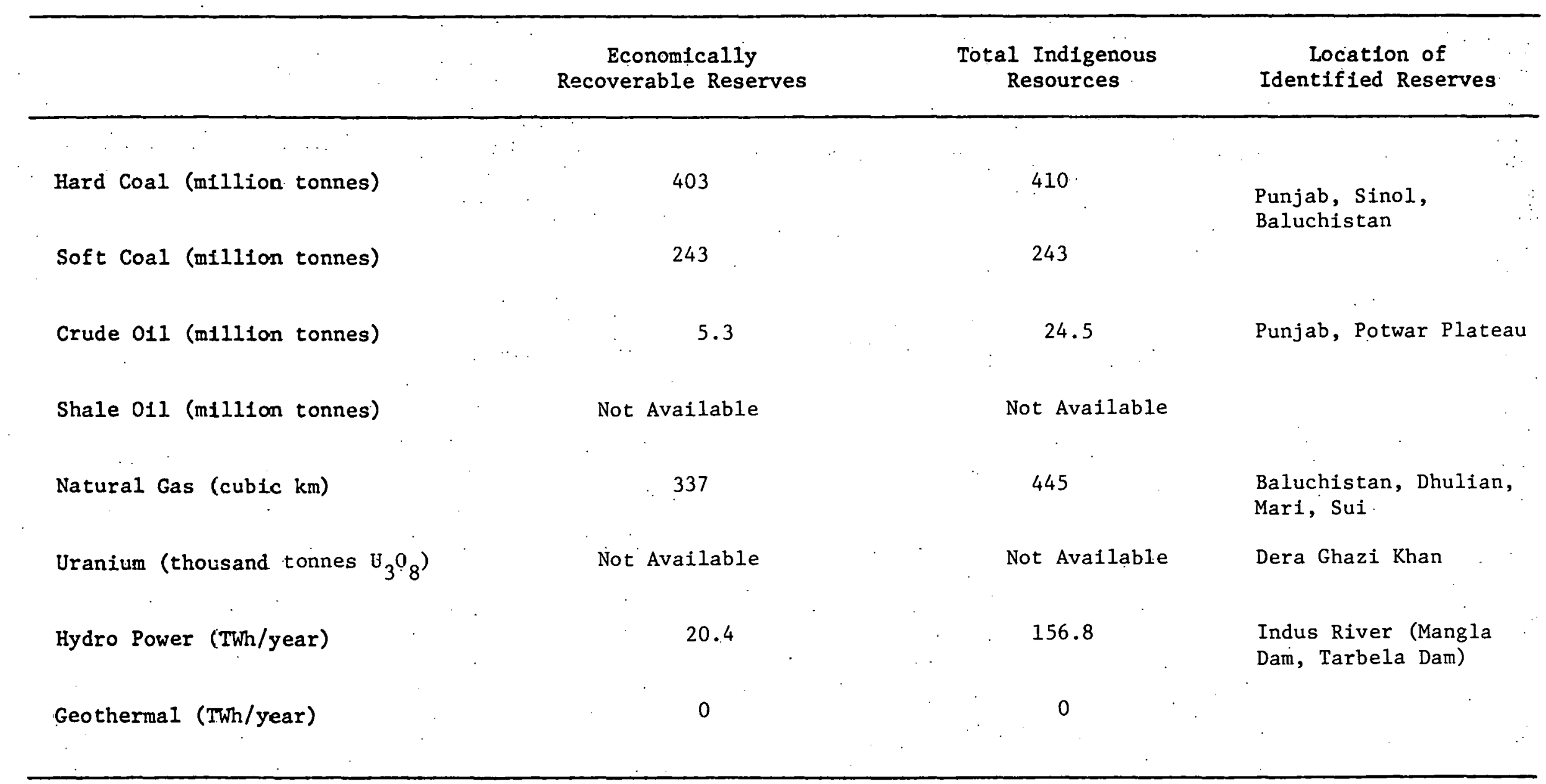




\section{ENERGY SUPPLY $197 j$}

Table 20.1.2

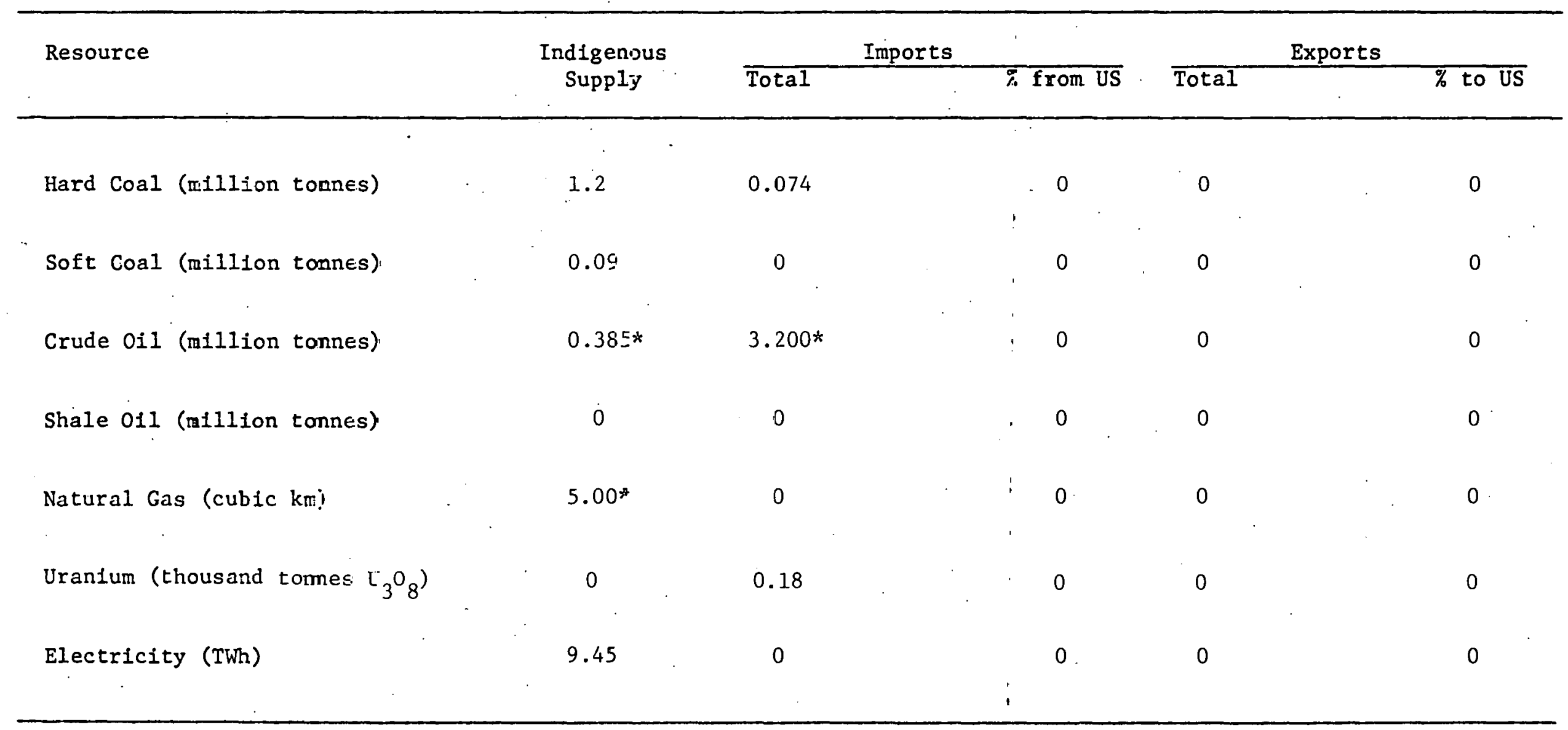

* UN Statistical office estinate 


\section{Table 20.1.3}

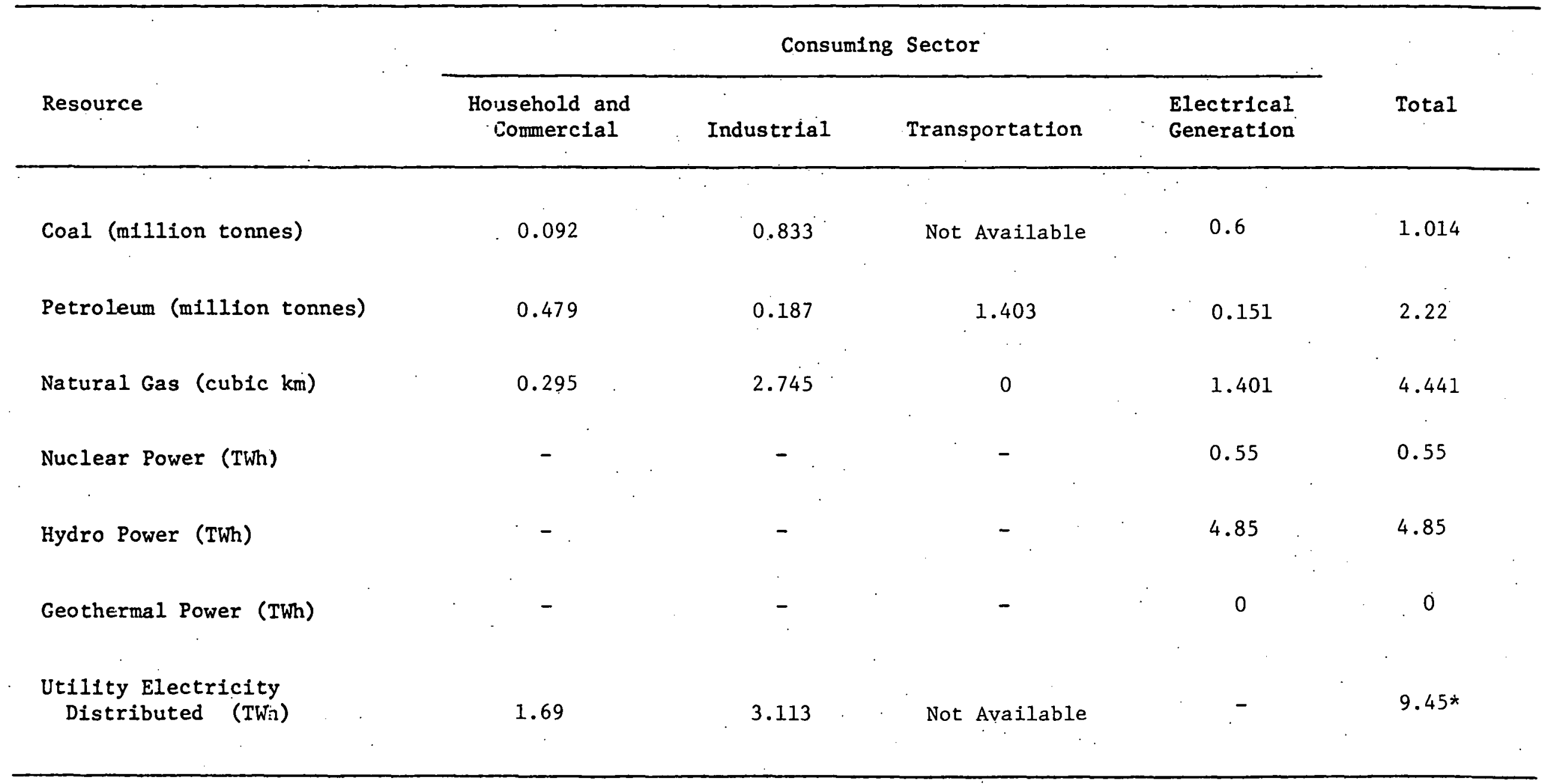

* UN Statistizal office estimate 
FORECASTS OF ANNUAL ENERGY DEMAND AND ELECTRICITY IEMAVD

Table 20.1.4

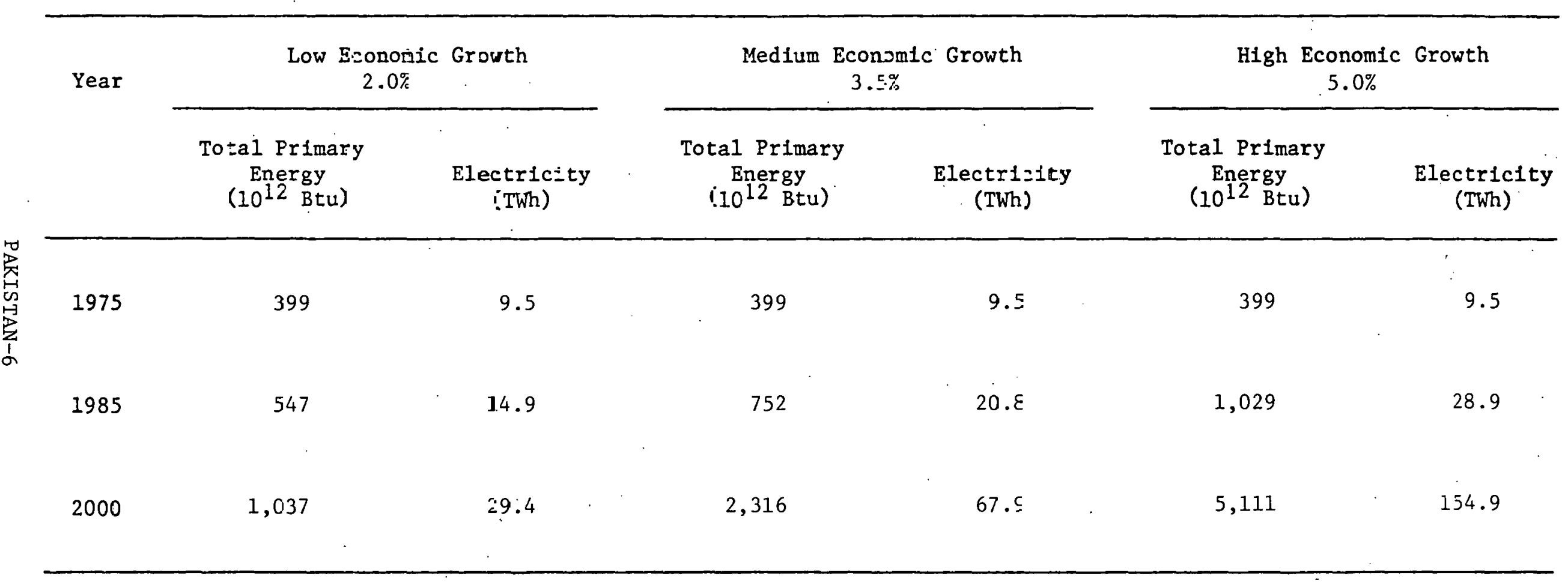


CONSUMPTION OF ENERGY RESOURCES

Table 20.1.5

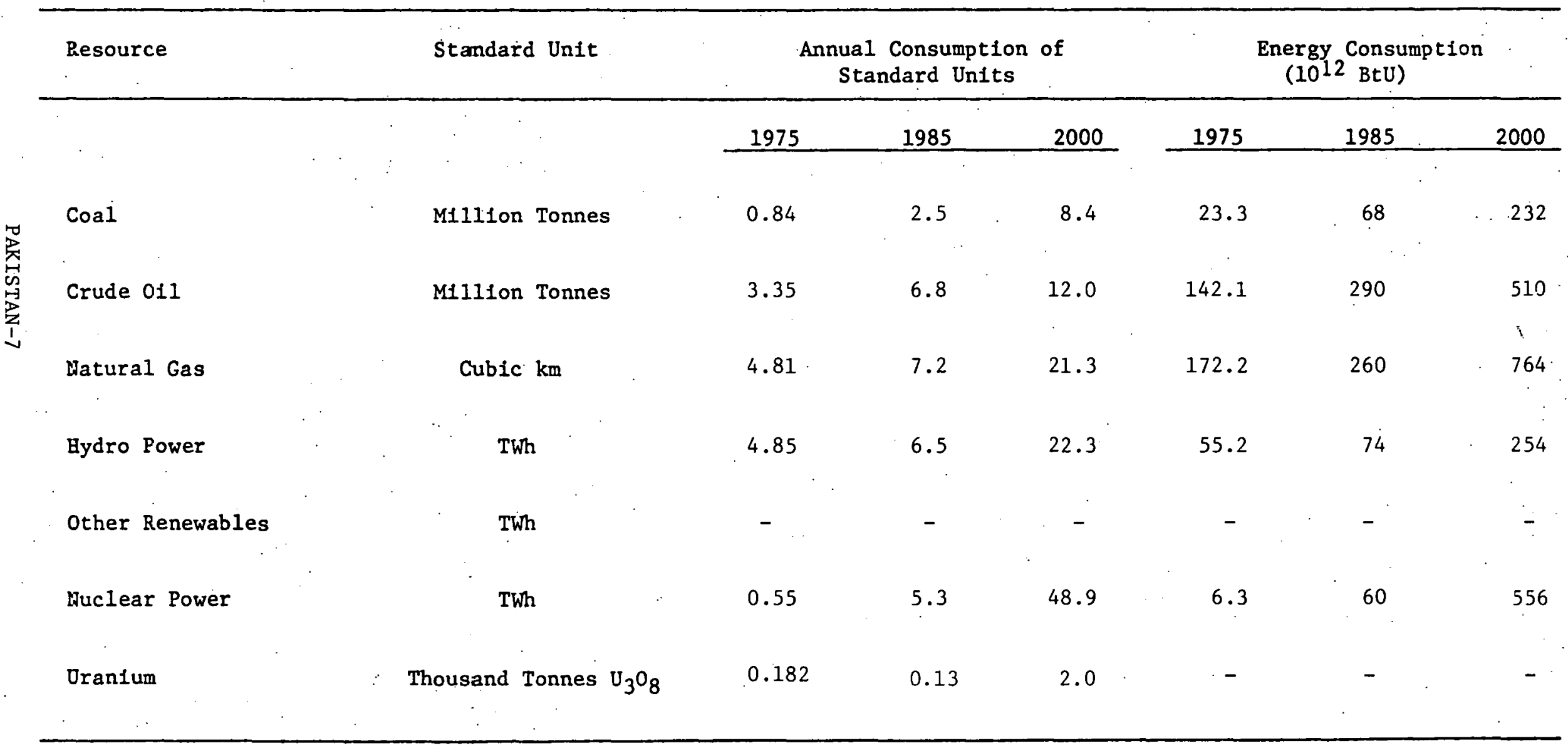


20.2 NUCLEAR HISTORY, CAPABILITY, COMMITMENT AND TRENDS

COMMERCIAL NUCLEAR POWER PLANTS

Table 20.2.1

\begin{tabular}{llccccc}
$\begin{array}{l}\text { Facility } \\
\text { Name }\end{array}$ & Utility & Vondor & $\begin{array}{c}\text { Facility } \\
- \text { Type }\end{array}$ & $\begin{array}{c}\text { Capacity } \\
\text { (MWe net) }\end{array}$ & Status* & SORP \\
\hline $\begin{array}{c}\text { Kanupp } \\
\text { Pakistan Atomic } \\
\text { Energy }\end{array}$ & Canada & CANDU & 125 & 0 & Apr 1972
\end{tabular}

* O-Operational 
PROJECTED NUCLEAR GENERATING CAPACITY MWe (net)

Table 20.2.2

\begin{tabular}{|c|c|c|c|c|c|c|c|c|c|}
\hline Year & PWR & BWR & Magnox & AGR & CANDU & Other & FBR & $\begin{array}{l}\text { Firm }+ \\
\text { Planned } \\
\text { Cumulative } \\
\text { Total } \\
\end{array}$ & $\begin{array}{l}\text { NAC } \\
\text { Cumulative } \\
\text { Projection }\end{array}$ \\
\hline pre-1977 & & & & & 125 & , & & 125 & 125 \\
\hline 1977 & & & & & & & & 125 & 125 \\
\hline 1978 & & & . & & & & & 125 & 125 \\
\hline 1979 & & & & & & & & 125 & 125 \\
\hline 1980 & & & & & & & & 125 & 125 \\
\hline 1981 & & & & & & & & 125 & 125 \\
\hline 1982 & & & & & & & & 125 & 125 \\
\hline 1983 & & & & & & & & 125 & 125 \\
\hline 1984 & 600 & & & & & & & 125 & 725 \\
\hline 1985 & & & & & & & & 125 & 725 \\
\hline 1986 & 600 & & & & & & & 125 & 1325 \\
\hline 1987 & 0 & & & & & & & 125. & 1325 \\
\hline 1988 & 300 & 300 & & & & & & 125 & 1925 \\
\hline 1989 & 0 & & & & .. & & & 125 & 1925 \\
\hline 1990 & 300 & 300 & & & & & & 125 & 2525 \\
\hline 1991 & 0 & & & & & & & 125 & 2525 \\
\hline 1992 & 450 & 450 & & & & & & 125 & 3425 \\
\hline 1993 & 0 & & & & & & & 125 & 3425 \\
\hline 1994 & 450 & 450 & & & & & . & 125 & 4325 \\
\hline 1995 & 0 & & & & & & & 125 & 4325 \\
\hline 1996 & 450 & 450 & & : & & & & 125 & 5225 \\
\hline 1997 & 450 & 450 & & & & & & 125 & 6125 \\
\hline 1998 & 450 & 450 & & & & & & 125 & 7025 \\
\hline 1999 & 450 & 450 & & & & & & 12.5 & 7925 \\
\hline 2000 & 450 & 450 & & & & & & 125 & 8825 \\
\hline . & & & . & & & & & & \\
\hline
\end{tabular}


NUCLEAR REACTOR VENDORS

\section{Overview}

Pakistan has no domestic reactor vendors. In view of the technological status of Pakistan, it is anticipated that the nation will depend upon reactor imports from foreign vendors.

Nuclear Reactor Vendor Support Industries

No substantial reactor vendor support industries currently exist. Pakistan is endeavoring to develop domestic skill and manufacturing industries; however lack of trained personnel, technology and financing limit this effort. 
NUCLEAR FUEL CYCLE FACILITIES

Overview

Pakistan is concentrating its efforts in two areas - uranium exploration, mining and milling; and reprocessing.

Uranium deposits do exist in Pakistan and it is believed that indigenous uranium resources are sufficient for the Kanupp Candu reactor. A pilot concentration plant is located at the Dera Ghazi Khan mining area.

Pakistan has contracted with France for a small reprocessing plant to be constructed at Chasma, on the Indes River. It is believed that most (reported to be 95\%) of the plant plans have been delivered. Financing, technical manpower, and lack of Franch export credit guarantees may hinder Pakistan's ability to construct the plant. Some international pressure is being applied in order to attempt to convert the plant design to a coprocessing scheme where the uranium and plutonium streams remain combined. If Pakistan does not agree to the coprocessing arrangement, France prefers not to carry through with this contract.

It has been noted in recent literature that Pakistan may be building a gas centrifuge enrichment plant. Pakistan has denied this, saying that equipment they have ordered, which could be used for an enrichment plant, is being ordered for military purposes: There is no firm substantiation of this however.

Pakistan has no fabrication facilities. 
NUCLEAR DEVELOPMENT OUTLOOK SUMMARY

Vested Interests in Current Reactor Technologies and Fuel Cycles

The single Pakistan CANDU reactor and the need for Pakistan to develop trained personnel to operate and maintain that reactor can be considered to create some degree of vested interest in the CANDU. Conversely, the planned construction of a reprocessing plant and possible imports of Framatome PWRs in the future could create equal personnel interest in LWR and plutonium fuel cycles. Substantial time, commitments and actual reactor/reprocessing plant construction would have to occur before major technological vested interests would exist.

\section{Current Trends in Nuclear Development Programs}

Uranium exploration and attempts to assure continued operation of the Kanupp reactor are the two clear trends in Pakistan. Financial, political, and trained personnel matters appear to severely restrict activities towards either further reactors or the reprocessing plant. 


\subsection{NUCLEAR TECHNOLOGY CAPABILITY AND RESOURCES}

\section{PROFESSIONAL LABOR FORCE PROFILE}

Table 20.3.1

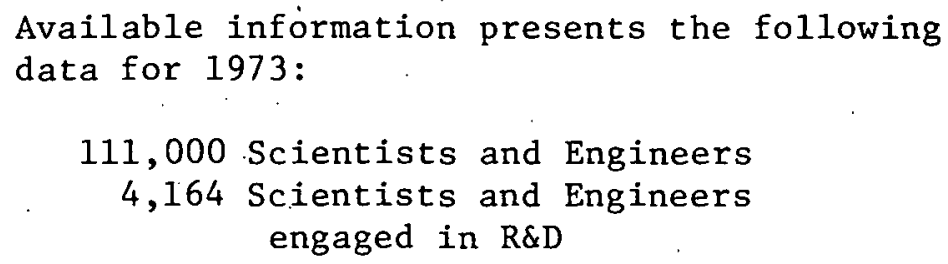

KEY TECHNICAL EDUCATIONAL RESOURCES

Table 20.3.2

Institution

University of Baluchistan

Gomal University

University of 'Islamabad

University of Karachi

University of Peshawar

University of the Punjab

University of Sind

University of Engineering and Technology
Location

Quetta

Dera Ismail Khan

Islamabad

Karachi

Peshawar

Lahore

Jamshoro-Sind

Lahore 
KEY GOVERNMENTAL NUCLEAR RESEARCH ORGANIZATIONS

Table 20.3.3

Name

Pakistan Atomic Energy

Communion

\section{Pakistani Science}

Foundarion

\section{Location}

Is lamabad

\section{Main Activities}

responsible for generation

of electric power from nuclear energy and the developing of nuclcar energy.

(modelled after US National Science Foundation.) overseas dissemination of a comprehensive scientific and technological information and dessemination center and administers a fund of money available for university research projects. 
REY PRIVATE NUCLEAR RESEARCH ORGANIZATIONS

Tab1e 20.3.4

Name

Owner

Location

Main Activities

Not Applicable 
RESE.ARCH AND TEST REACTORS

List of Reacto:s

Table 20.3.5

\section{Facility}

Name

PARR
Location

Is 1 amabad
Ower

PAEZ
Constructor

AMF Atomics
Facility Type

research pool
Facility Status MW(th) Status* COD 
INDIGENOUS CAPABILITY TO DESIGN AND SUPPLY RESEARCH AND TEST REACTORS AND FUEL SERVICES Summary of Reactor Orders by Vendor and Country

\section{Table 20.3.6}

Facility Facility Status Scope of

Name

Type $\underline{\text { MW(th) }}$ Status*

COD Services

Not Applicable

* O-Operational; U-Under Construction; P-Planned; S-Shutdown 
SUMMARY OF FUEL SEEVICES FOR RESEARCH AND TEST REAOTORS

Table 20.3.7

Facility

Name

Location

Facility

Type

Capacity statis

Status* $^{*}$ Year $\quad$ Shareholdings

Not Applicable

* O-Operationa1; U-Under Construction; P-Planred; $\mathbf{S}$-Shutdown 
20.4 ECONOMIC RESOURCES FOR NUCLEAR POWER DEVELOPMENT

ECONOMIC DATA PROFILE

Table 20.4.1

$\begin{array}{llll}\text { GNP (Current million \$) } & -15,800(1977) & \text { Inflation Rate } & -9 \%(1977) \\ \text { Exports (million \$) } & -1,292(1977) & \text { Imports (milion \$) } & -2,770(1977) \\ \text { Per Capita Income (\$) } & -192.6(1977) & \text { Disposable Income (\$) } & - \\ \text { Monetary Unit } & - \text { Rupee } & \text { Exchange Rate (/US\$) } & 9.93(4 / 77) \\ \text { Population (million) } & -72.0(1976) & \end{array}$


20.4.2 GOVERNMENTAL NUCLEAR ENERGY R\&D BUDGET

PAKISTAN ATOMIC ENERGY COMMISSION BUDGET

1975-76

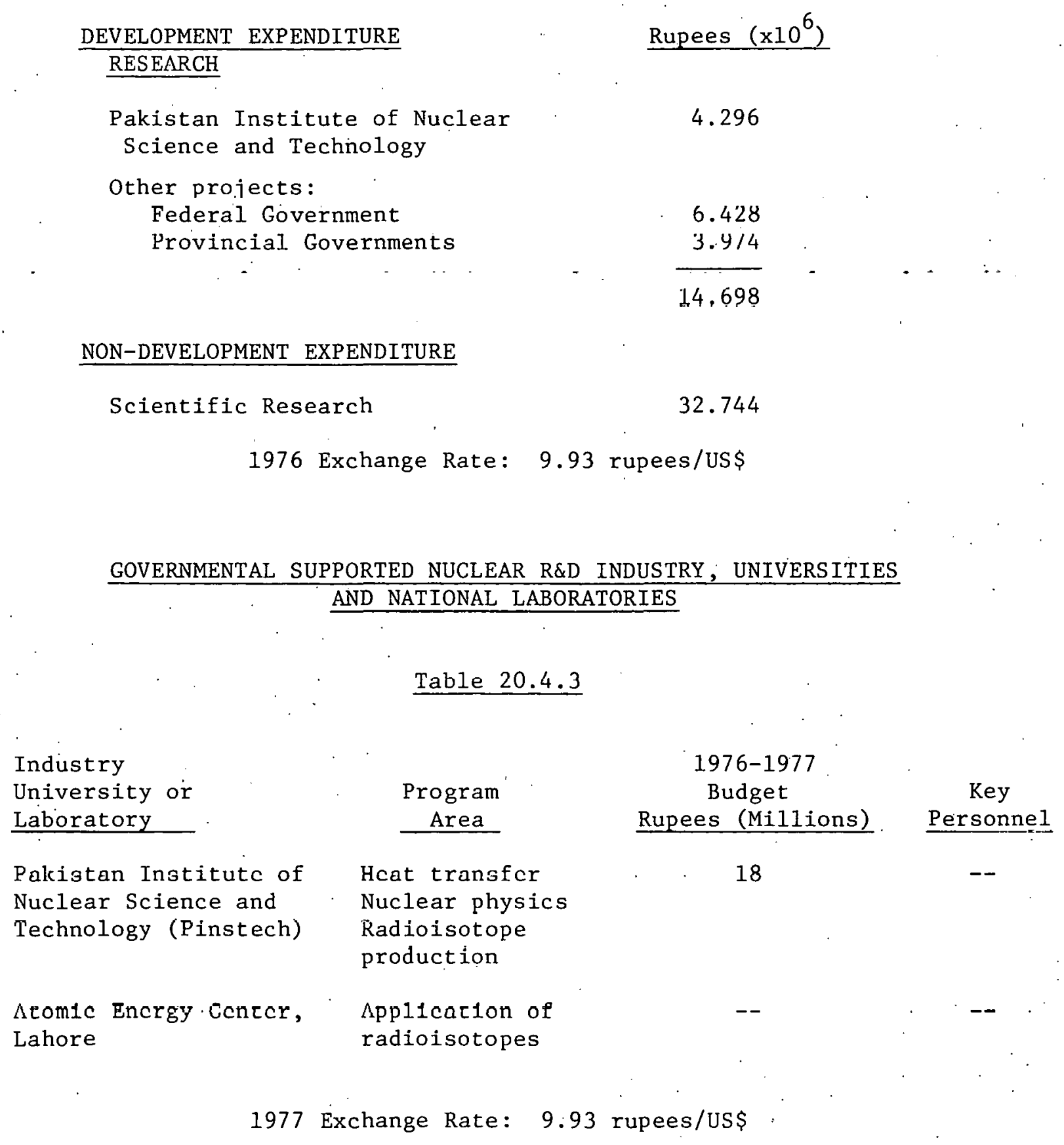


20.4.4 ROLE OF PRIVATE INDUSTRY IN NUCLEAR ENERGY R\&D

The private sector remains an insignificant factor in Pakistan's energy R\&D program. The government of Pakistan, however, is looking for means to stimulate activities in the mineral field.

ECONOMIC PROFILE OF REACTOR VENDORS AND FUEL CYCLE FACILITIES

Table 20.4.5

Name

Share Capital

Assets

Sales

Not Applicable

20.4.6 MODE OF FINANCING OF NUCLEAR POWER PLANTS

Pakistan seeks collaboration from friendly countries, the World Bank and other agencies, as well as "harnessing internal sources." 


\subsubsection{ENERGY POLICY - BASIC LEGISLATION}

There is no basic legislation dealing directly with energy R\&D.

Pakistan law, however, will not permit any significant expansion of private interests into new deposits or new sectors of mineral development. Private enterprise is only minimally involved in nonpetroleum mineral development in Pakistan.

1. PAEC - established 1955.

2. Pakistan Atnmir Finergy Cnmngil est. 1958 - reports to Scientific and Technological Research Division of the President's Secretariat.

3. PAEC initiated uranium prospecting program - early 1960.

4. Karachi Nuclear Power Project (KANUPP) approved by GOP in 1964.

5. KANUPP power plant inaugurated in 1972.

6. Nuclear Safety \& Radiation Protection Ordinance - 1973 (was scheduled to be in force in 1973). 
LEGISLATIVE-PARLIAMENTARY consisting of two houses: The Senate and the National Assembly which must approve all major legislation.

EXECUTIVE-PRESIDENT is constitutional head of the government. The dominant government figure, however, is the PRIME MINISTER. Normally, legislation must be approved by the National Assembly, but important decisions are often made by executive. fiat. The Prime Minister must approve all energy policies and actions, but this is largely delegated to the interagency Ministerial-level Executive Committee of the National Economic Council (ECNEC).

\section{ADDITIONAL ENERGY STRUCTURE}

THE PLANNING COMMISSION is responsible for the overa11 coordination of power planning in relation to the economic development of the Country.

PAKISTAN ATOMIC ENERGY COMMISSION (PAEC) formulates nuclear energy policy. Its jurisdiction includes:

1. Formulation of nuclear policy

2. Operation of nuclear installations

3. Representation of Pakistan at international meetings on nuclear energy matters

4. Research and application of nuclear technology

5. Exploration of radioactive materials

6. Manpower training

On July 5, 1977, the Pakistani military seized power and imposed martial law. The Martial Law Administration is headed by a four-man military council with General Zia ul-Haq as chief martial law administrator. 


\subsubsection{ORGANIZATION FOR IMPLEMENTATION OF NUCLEAR ENERGY POLICY AND R\&D}

PAKISTAN ATOMIC ENERGY COMMISSION (PAEC) is controlled by a four-man commission, headed by a chairman (Munir Ahmed Khan). PAEC is in charge of all aspects of nuclear policy.

Executive Committee of National Economic Council approves nuclear power plant projects.

Directorate of Industrial Liaison promotes participation of local industries and technical capabilities in implementing nuclear power program.

PAEL, in collaboration with the Ministry of Fuel, Puwer \& Natural Kesources, the Planning Commission, Water \& Power Development Authority (WAPDA) and Karachi Electric Supply Corporation (KESC), works to evolve long-term nuclear power development programs.

\subsubsection{NUCLEAR ENERGY POLICY AND OBJECTIVES}

The object1ve of the Government of Pakistan is to lessen, and if possible, eliminate the Country's dependence on foreign energy sources. The major energy source is imported oil which contributes more then 40 per cent of the total conmercial energy, followed by natural gas, hydroelectric, coal and nuclear power.

Pakistan has expressed interest in nuclear energy in view of:

$$
\begin{aligned}
& \text { 1. limited indigenous natural resources } \\
& \text { 2. high cost of imported fuel } \\
& \text { 3. rapidly growing demand for energy } \\
& \text { 4. ambitious economic development targets }
\end{aligned}
$$

The Government of Pakistan, however, remains open to reconsider its options hased on the cost of available allernatives.

Tn nrier to provide the supfly of nuclcar pover nccded for ceonomic development, PAEC has establisher a plan for the construction of several nuclear plants. Because of limited financial resources, financing would be sought from friendly countries, the World Bank and other agencies. 


\subsubsection{NUCLEAR ENERGY R\&D - STATUS AND OUTLOOK}

Nuclear energy development in Pakistan is at very beginning stages.

Two nuclear power plants are now in operation:

1. Karachi Nuclear Power Plant (KANUPP) - 137 MWe heavy water moderated reactor established by the PAEC with Canadian help, became critical in August 1971.

2. Experimental reactor at Pakistan Institute of Science and Technology (PINSTECH) near Islamabad.

PAEC Chairman Munir Ahmed Khan has indicated that Pakistan does not intend to build any additional power plants that would require imported oil or domestic natural gas. The Government of Pakistan is planning to build several more nuclear reactors by 2000 . The Chasma Nuclear Power Plant (CHASNUPP) is a proposed 600 MW nuclear plant to be built at Chasma Barrage to feed the northern grid. The reactor type is not yet decided. The Government of Pakistan has also arranged with France to purchase a 100 ton/year reprocessing plant in order to produce their own nuclear fuel. The deal is stymied and the plant may not be built.

\subsubsection{NUCLEAR ENERGY R\&D - PRIORITIES}

The major Pakistan priorities are:

- Increase domestic nuclear technology to decrease dependence on foreign countries.

- Develop uranium resources.

- Construct fabrication plant for KANUPP.

- Acquire a reprocessing facility. 


\subsubsection{ROLE OF GOVERNMENT IN NUCLEAR FACILITIES CONSTRUCTION AND OPERATION}

Pakistan Atomic Energy Commission

Administrative Ministry/Division

Planning Commission

(for circulating schemes for obtaining views of the Ministry of Finance and others concerned)

Cencral Development Worklng Parcy (CDWP)

(for consideration of schemes and projects)

Executive Committee of National Economic Council (ECNEC)

(for final approval of projects and schemes).

The President of Pakistan is Chairman of ECNEC.

After completing the above process, the Administrative Ministry/Division accords a formal sanction for execution of the schemes and projects.

PAEC's relationship to the utilities is that PAEC has constructed and is operating the KANUPP power plant and is selling power to KESC on a contract. 
20.6 NON-NUCLEAR ENERGY FACILITIES AND FUEL SUPPLY

PÁKISTAN-27 


\section{ENERGY GENERATIDN FACILITIE3 IN EX-STENCE AND FIRMLY PLANNED PROJUCING 100 MWe (net)}

Table 20.6.1

\begin{tabular}{|c|c|c|c|}
\hline $\begin{array}{l}\text { Facility } \\
\text { Name } \\
\end{array}$ & Location & $\begin{array}{l}\text { Utilitil } \\
\text { Owner }\end{array}$ & Vendor \\
\hline Korangi & Karachi & ZESC & Hitachi \\
\hline Guddu I + II & Upper Sir. & NAPDA & \\
\hline Guddu III & Upper Sird & "NAPDA" & \\
\hline Multan & $\begin{array}{l}\text { Northern } \\
\text { Sector }\end{array}$ & NAPDA & \\
\hline Mult an & $\begin{array}{l}\text { Northern } \\
\text { Sector }\end{array}$ & NAPDA & \\
\hline Lyal1pur & $\begin{array}{l}\text { Northern } \\
\text { Sector }\end{array}$ & NAPDA & \\
\hline Lyallpur & $\begin{array}{l}\text { Northern } \\
\text { Sector }\end{array}$ & NAPDA & \\
\hline Mangla $1-4$ & $\begin{array}{l}\text { Northern } \\
\text { Sector }\end{array}$ & NAPDA & \\
\hline Mangla 5-6 & $\begin{array}{l}\text { Northern } \\
\text { Sector }\end{array}$ & NAPDA & \\
\hline Mangla 7-8 & $\begin{array}{l}\text { Northern } \\
\text { Sector }\end{array}$ & NAPDA & \\
\hline Warsak $1-4$ & $\begin{array}{l}\text { Northern } \\
\text { Sector }\end{array}$ & WAPDA & \\
\hline
\end{tabular}

\begin{tabular}{|c|c|c|c|}
\hline $\begin{array}{c}\text { Fazility } \\
\text { Type } \\
\text { (Fuel Type) } \\
\end{array}$ & $\begin{array}{l}\text { Capacity } \\
\text { (MWe net) }\end{array}$ & Status* & COD \\
\hline Gas/Oi1 & 257 & 0 & $1965 / 1969$ \\
\hline Therma1 (Gas) & 220 & 0 & 1974 \\
\hline Thermal (Gas) & 200 & $\mathrm{P}$ & 1977 \\
\hline Thermal (Gas) & 266 & 0 & $1960 / 1963$ \\
\hline Thermal (Gas) & 200 & $\mathrm{P}$ & 1977 \\
\hline Thermal (Gas) & 141 & 0 & 1967 \\
\hline Thermal (Gas) & 200 & $\mathrm{P}$ & 1975 \\
\hline Hyćro & 400 & 0 & $1967-69$ \\
\hline Hyćro & 200 & 0 & 1974 \\
\hline Hyċro & 200 & $\mathrm{P}$ & 1977 \\
\hline Hyċro & 160 & 0 & 1960. \\
\hline
\end{tabular}

*0-Uperationa1; U-Under Construction; F-Planned; S-Shutdown 


\section{ENERGY GENERATION FACILITIES IN EXISTENCE AND FIRMLY PLANNED PRODUCING 100 MWe (net)}

Table 20.6.1 (cont.)

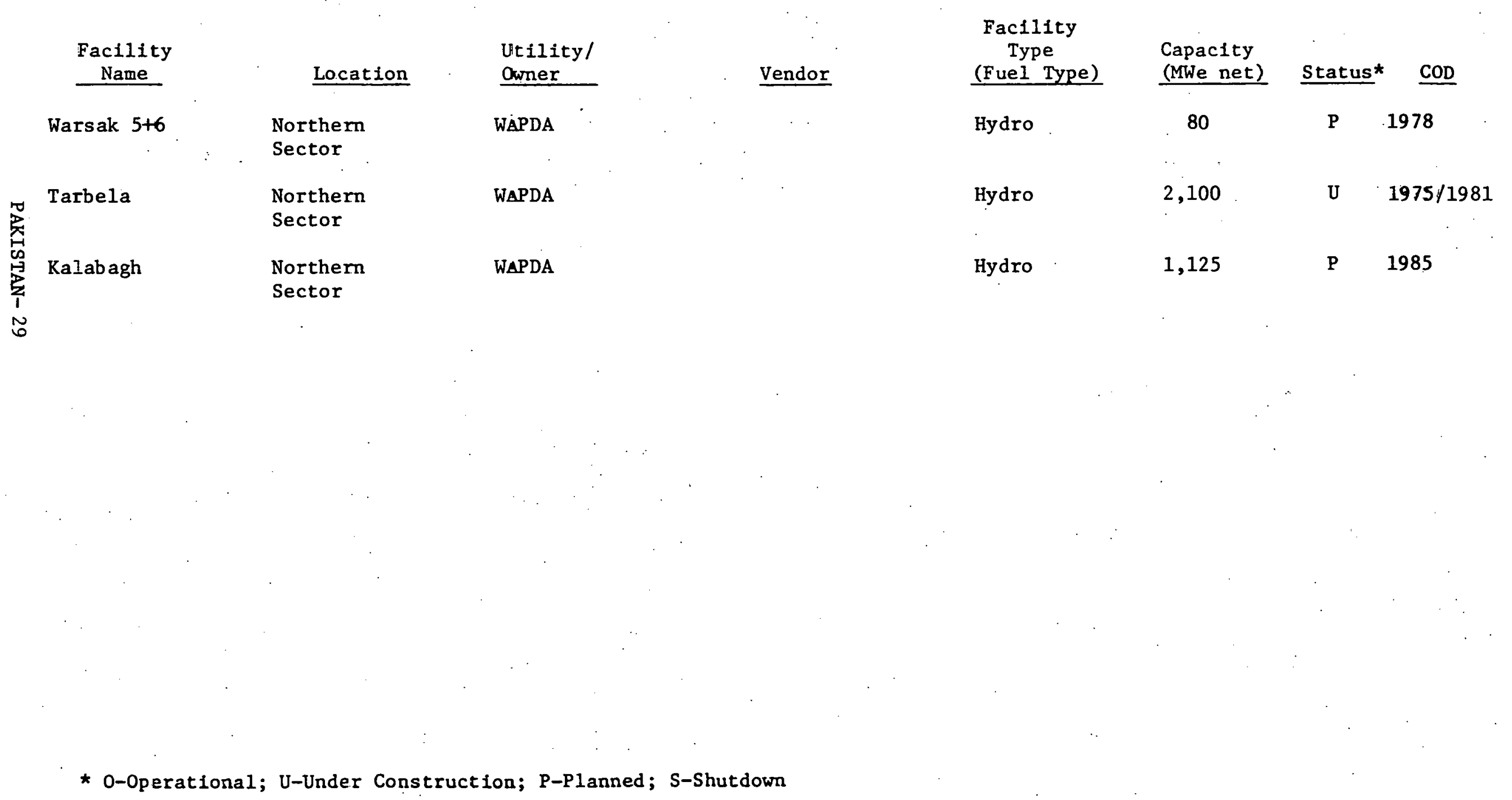


SUMMARY OF ENERGY GENERATION FACILITIES IN EXISTENCE AND PLANNED

Table 20.6 .2

\begin{tabular}{|c|c|}
\hline Year & Capacity - MWe (net) \\
\hline 1975 & 2,854 \\
\hline 1980 & 5,384 \\
\hline 1985 . & 7,109 \\
\hline 1990 & 11,500 \\
\hline $1995^{\circ}$ & \\
\hline 2.nกn & 10,000 \\
\hline
\end{tabular}




\section{LISTING OF FUEL SUPPLY FACILITIES IN EXISTENCE AND FIRMLY PLANNED}

Tab1e 20.6.3

\begin{tabular}{|c|c|c|c|c|c|}
\hline $\begin{array}{c}\text { Facility } \\
\text { Name } \\
\end{array}$ & Location & Owner & $\begin{array}{c}\text { Facility } \\
\text { Type } \\
\end{array}$ & Capacity $* *$ & Status ${ }^{*}$ \\
\hline Sor Range & Baluchistan & & Coal Field & 1.5 & 0 \\
\hline Deghari & Baluchistan & & Coal Field & 1.5 & 0 \\
\hline Mach & Baluchistan & & Coal Field & 1.5 & 0 \\
\hline Sharigh & Baluchistan & & Coal Field & 1.5 & 0 \\
\hline Makarwal & Punjab & & Coal Field & 1.5 & 0 \\
\hline Salt Range & Punj $a b$ & & Coal Field & 1.5 & 0 \\
\hline Jhimpir & Sind & & Coal Field & 1.5 & 0 \\
\hline Lakhra & Sind & & Coal Field & 1.5 & 0 \\
\hline Balkassar & Punjab & OGDC & Oil Field & 980 & 0 \\
\hline Dhulian & Punj $a b$ & OGDC & Oil Field & 750 & 0 \\
\hline Joyamair & Punjab & OGDC & Oil Field & 440 & 0 \\
\hline Meyal & Punjab & OGDC & Oil Field & 4,500 & 0 \\
\hline Tut & Punjab & OGDC & Oil Field & 2,800 & 0 \\
\hline
\end{tabular}

* O-Operational; U-Under Construction; P-Planned; S-Shutdown

** Coal - million tonnes/year; 0il - barrels/day 


\section{LISTING CF FUEL SUPPLY FACILITIES IN EXISTENCE AND E-FHLY PLANNED}

Teble 20.6.3 (Continued)

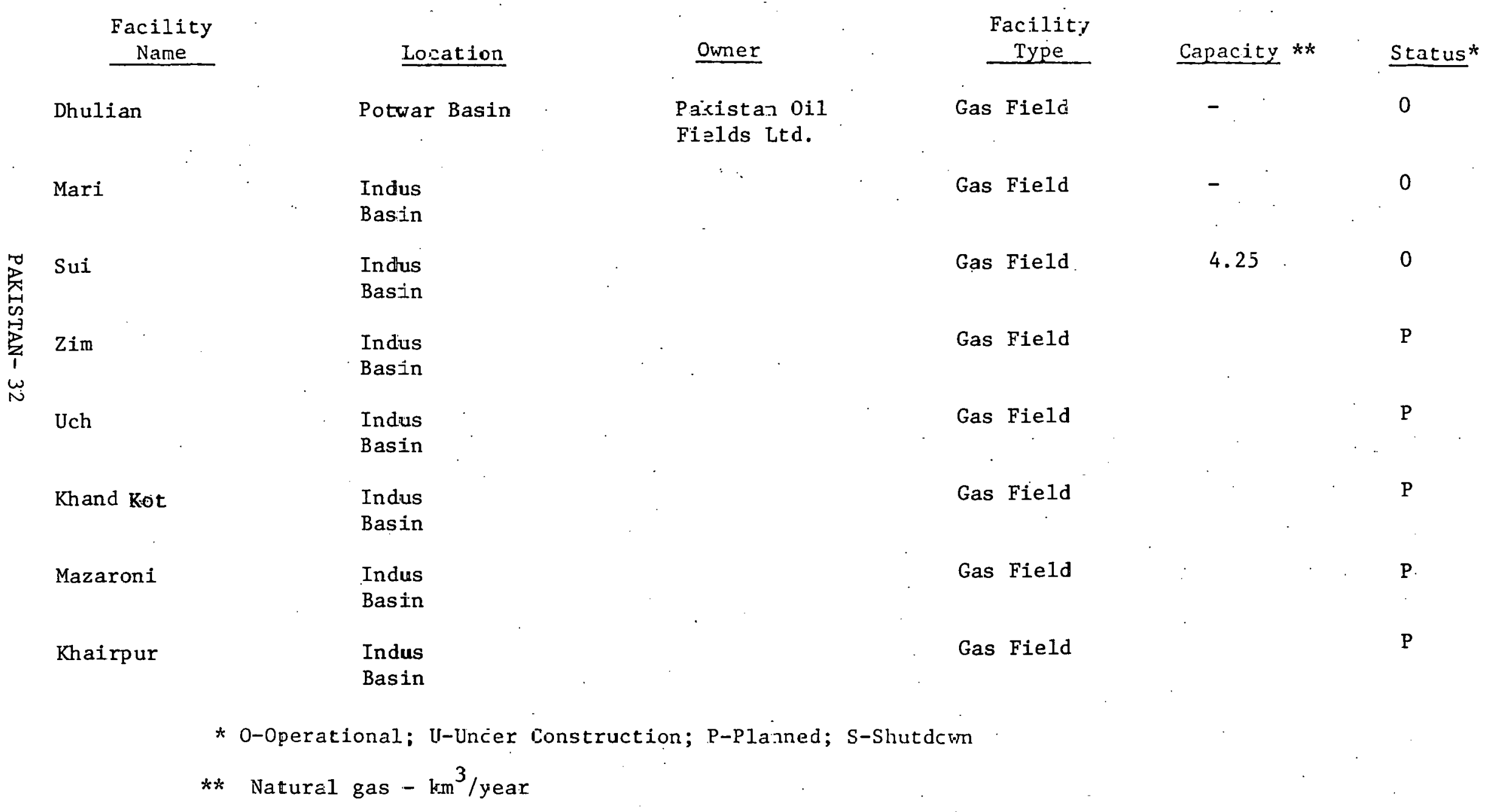


LISTING OF FUEL SUPPLY FACILITIES IN EXISTENCE AND FIRILY PLANNED

Table 20.6.3 (Continued)

Facility

Name

Sarising
Location

Near Karachi

\section{Factlity}

Type

Gas Field
Capacity **

$\underline{\text { Status* }}^{*}$

$\mathrm{P}$

* O-Operational; U-Under Construction; P-Planned; S-Shutdown

* Natural gas - $\mathrm{km}^{3} /$ year 
Tab1e $\quad 20.6 .4$

COAL (million tonnes) Indigenous Supply

Imports

Exports

CRUDE OIL (million tonnes)

Indigenous Supply

1.24

3.36

1.26

Imports

10.14

Exports

SHALE ONL (million tonnes)

Indigenous Supply

0

0

Imports

Exports

NATURAL GAS (cubic kilometers)

Indigenous Supply

9.43

11.05

Imports

10.25

Exports

2.23

--

URANIUM (kilotonnes $\mathrm{U}_{3} \mathrm{O}_{8}$ )

Indigenous Supply

Imports

0

0

Exports

.13

0

2.0

0 
SECTION 21

PHILIPPINES

$\sqrt{1}$ 
21.1 PROJECTED INDIGENOUS ENERGY RESOURCES, DEMANDS AND RELATED INFORMATION

\section{INDIGENOUS RESOURCES}

Coal resources for the Philippines were unobtainable from the World Energy Conference Survey of 1976 (ref. 1.2). The earlier survey of 1974 (ref. 1.1) was also unable to obtain figures for the economically recoverable amount, but total resource was given as 91.12 million tonnes. Reference 1.28 gives estimates of 36-125 million tonnes, the wide range being due to inadequacy of geological data. The 1975 U. N. Statistical Year Book, N. Y., 1976, 1ists 211 million tonnes as total coal resources.

No figure for resources of crude oil and shale oil are available.

The total resource on natural gas is given as $0.071 \mathrm{~km}^{3}$ (refs. 1.2). This is confirmed in reference 1.28 , the assessment of which is based upon pilot surveys in Isabela. Natural gas is not included in the Philippine energy plan.

Hydro-power represents approximately $3 \%$ of total Asian output and the theoretical capacity is estimated at $19.6 \mathrm{TWh}$ of which $7.6 \mathrm{TWh}$ is economically recoverable.

Four studies to utilize geothermal hot water and steam resources for the generation of electric power are under progress. The first at Tiwi, Luzon, may lead to the installation of 9 units of $700 \mathrm{MW}$ combined capacity. The second at Los Barnos, Luzon, may lead to an installed capacity of $400 \mathrm{MW}$. Two other studies are in progress for geothermal resources at Tongonan on Leyte Island and on Negros Island, but no details are available.

The government is spurring a nationwide search for recoverable uranium. There are surveys being conducted in the Larap-Paracale district, Camarines Norte. Other areas investigated in 1978 and currently are the Bagacay mines in Samar and the Magna Rosa prospect in the Caramoan peninsula.

ENERGY SUPPLY

A small quantity. of coal is produced ( 0.105 million tonnes, ref. 1.5). No other resource is produced internally.

0il imports are relatively large at 8.8 million tonnes (ref. 1.5) and have becn rcasonably constant over the last five years.

PATTERNS OF ENERGY USE

Figures for Table 21.1.3 were supplied by private communication.

Utility electricity distributed quantities are from an extract of information supplied by the Philippines in 1977 for "Electric Power in Asia and the Pacific 1975 and 1976" (ref, 1.50). 
FORECASTS OF ENERGY SUPPLY AND DEMAND

The energy and electricity demand forecasts for the Philippines presented in Table 21.1 .4 indicate an average annual rate of growth of $4.0 \%$ to $7.6 \%$ for total primary energy demand and $4.0 \%$ to $10.3 \%$ for electricity demand.

Forecasts of the growth of energy demand have been prepared by the Energy Development Board of the Philippines (ref. 1.28) and these indicate a total primary energy demand of $836 \times 10^{12}$ Btu in 1985 increasing to $2,350 \times 10^{12}$ Btu by 2000 . Electricity demand forecasts are implied in the forecast of energy requirement of the electricity generating sector and indicate a total electricity demand of 35 TWh in 1985 and 127 TWh in 2000.

The breakdown of energy demand to show the contribution from each source of supply is given in Table 21.1.5. These figures reflect the relative importance of each energy source as indicated in reference 1.28 which provided a breakdown of the EDB forecasts for 1985 and 2000. They show a decline in the relative importance of oil which contributed $88 \%$ in 1975 , but is expected to contribute on 1 y $75 \%$ in 1985 and $51 \%$ in 2000 .

Installed nuclear capacity in 2000 is projected to be 3,000 MW. The first reactor, $P N P P-1$, is now under construction with a second, similar reactor projected for operation in 1988-1989. There are no offlclal plans yet for later reactors.

Geothermal energy is a major resource in the Philippines and at the moment it is expected that this renewable resource will account for approximately $10 \%$ of the total primary energy demand in the year 2000 (ref. 1.28).

It is also planned to develop the use of solar energy to the extent of meeting approximately $8 \%$ of total demand in 2000 from this source. 
INDIGENOUS ENERGY RESOURCES.

Table 21.1.1

\begin{tabular}{|c|c|c|c|}
\hline & $\begin{array}{c}\text { Economically } \\
\text { Recoverable Resèrves }\end{array}$ & $\begin{array}{l}\text { Total Indigenous } \\
\text { Resources }\end{array}$ & $\begin{array}{l}\text { Location of } \\
\text { Identified Reserves }\end{array}$ \\
\hline Hard Coal (million tonnes) & 0 & 0 & . \\
\hline Soft Coal (million tonnes) & Not Available & 91.12 & $\begin{array}{l}\text { Cebu, Malangas in Zomoan- } \\
\text { ga del Sur, Somerara } \\
\text { Island in Antigue }\end{array}$ \\
\hline Crude 011 (million tonnes) & 0 & 0 & \\
\hline Shale 011 (m1111on tonnes) & 0 & 0 & \\
\hline Natural Gas (cublc km) & Not Available & 0.071 & Isabela \\
\hline Uranium (thousand tonnes $\mathrm{U}_{3} \mathrm{O}_{8}$ ) & 0.4 & 0.4 & $\begin{array}{l}\text { Camarines Norte, } \\
\text { Samar }\end{array}$ \\
\hline Hydro Power (Thh/year) & 7.6 & 19.6 & Luzon, Mindanao, Binga \\
\hline Geothermal (TWh/year) & See Text & & Mindanao, Luzon \\
\hline
\end{tabular}


ENERTY SUPPLY 1975

Tajle 21.1 .2

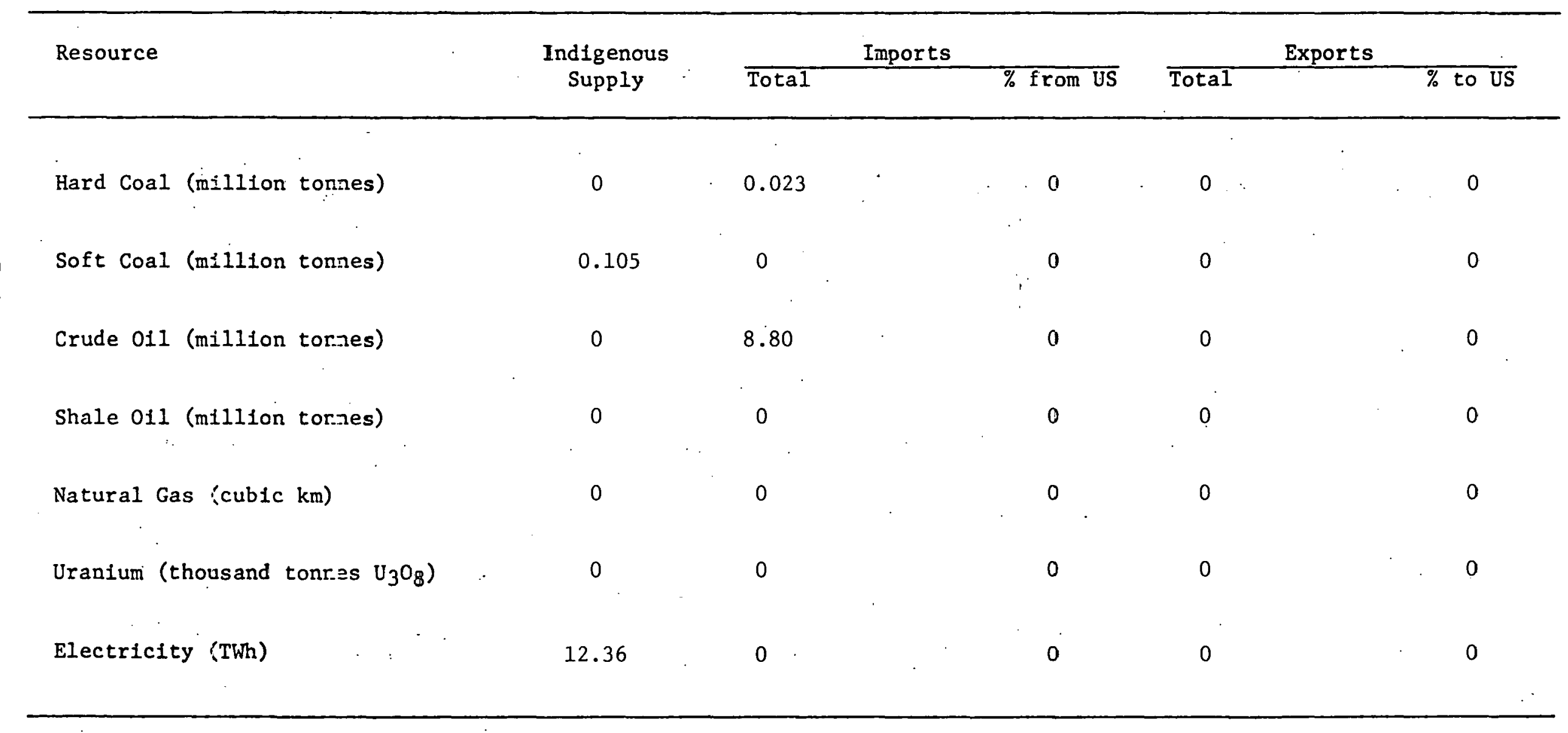


Table 21.1.3

\begin{tabular}{|c|c|c|c|c|c|}
\hline \multirow[b]{2}{*}{ Resource } & \multicolumn{4}{|c|}{ Consuming Sector } & \multirow[b]{2}{*}{ Total } \\
\hline & $\begin{array}{l}\text { Household and } \\
\text { Commerctal }\end{array}$ & Industrial & Transportation & $\begin{array}{l}\text { Electrical } \\
\text { Generation }\end{array}$ & \\
\hline Coal (million tonnes) & & 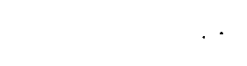 & & 0 & \\
\hline Petroleum (m1llion tonnes) & 1.19 & 2.7 & 3.8 & 0,88 & 8.57 \\
\hline Natural Gas (cublc km) & 0 & $a$ & 0 & 0 & \\
\hline Nuclear Power (TWh) & 0 & 0 & 0 & 0 & 0 \\
\hline Hydro Power (TWh) & 0 & 0 & 0 & 3.719 & 3.719 \\
\hline Geothermal Power (TWh) & 0 & 0 & 0 & 0 & 0 \\
\hline $\begin{array}{l}\text { Utility Electricity } \\
\text { Distributed (TWh) }\end{array}$ & 4.55 & 6.16 & 0 & 1.58 & 12.29 \\
\hline
\end{tabular}


FORECASTS OF ANNUAL ENERGY DEMAND AND ELECTRICITY DEMATD

Table 21.1 .4

\begin{tabular}{|c|c|c|c|c|c|c|}
\hline \multirow[t]{2}{*}{ Year } & \multicolumn{2}{|c|}{$\begin{array}{l}\text { Low Ecozomic G=ovth } \\
3.0 \%\end{array}$} & \multicolumn{2}{|c|}{$\begin{array}{c}\text { Medium Economic Growth } \\
5.0 \%\end{array}$} & \multicolumn{2}{|c|}{$\begin{array}{c}\text { High Economic Growth } \\
7.0 \%\end{array}$} \\
\hline & $\begin{array}{c}\text { Total Primary } \\
\text { Energy } \\
\quad \quad\left(10^{12} \text { Btu }\right)\end{array}$ & $\begin{array}{c}\text { Eleztriclty } \\
(\mathrm{TWh})\end{array}$ & $\begin{array}{c}\text { Total Primary } \\
\text { Energy } \\
\text { (10 } 12 \text { Btu })\end{array}$ & $\begin{array}{l}\text { Electricity } \\
\text { (TWh) }\end{array}$ & $\begin{array}{c}\text { Total Primary } \\
\text { Energy } \\
. \quad\left(10^{12} \text { Btu }\right)\end{array}$ & $\begin{array}{c}\text { Electricity } \\
\text { (TWh). }\end{array}$ \\
\hline 1975 & 414 & $12 . \dot{4}$ & 414 & 12.7 & 414 & 12.4 \\
\hline 1985 & 561 & $16 . "$ & 783 & 22.1 & 902 & 29.7 \\
\hline & & . & . & & . & . \\
\hline 2000 & 1,104 & 32.7 & 1,546 & $69 . J$ & 2,576 & 143.4 \\
\hline
\end{tabular}




\section{CONSUMPTION OF ENERGY RESOURCES}

Table 21.1.5

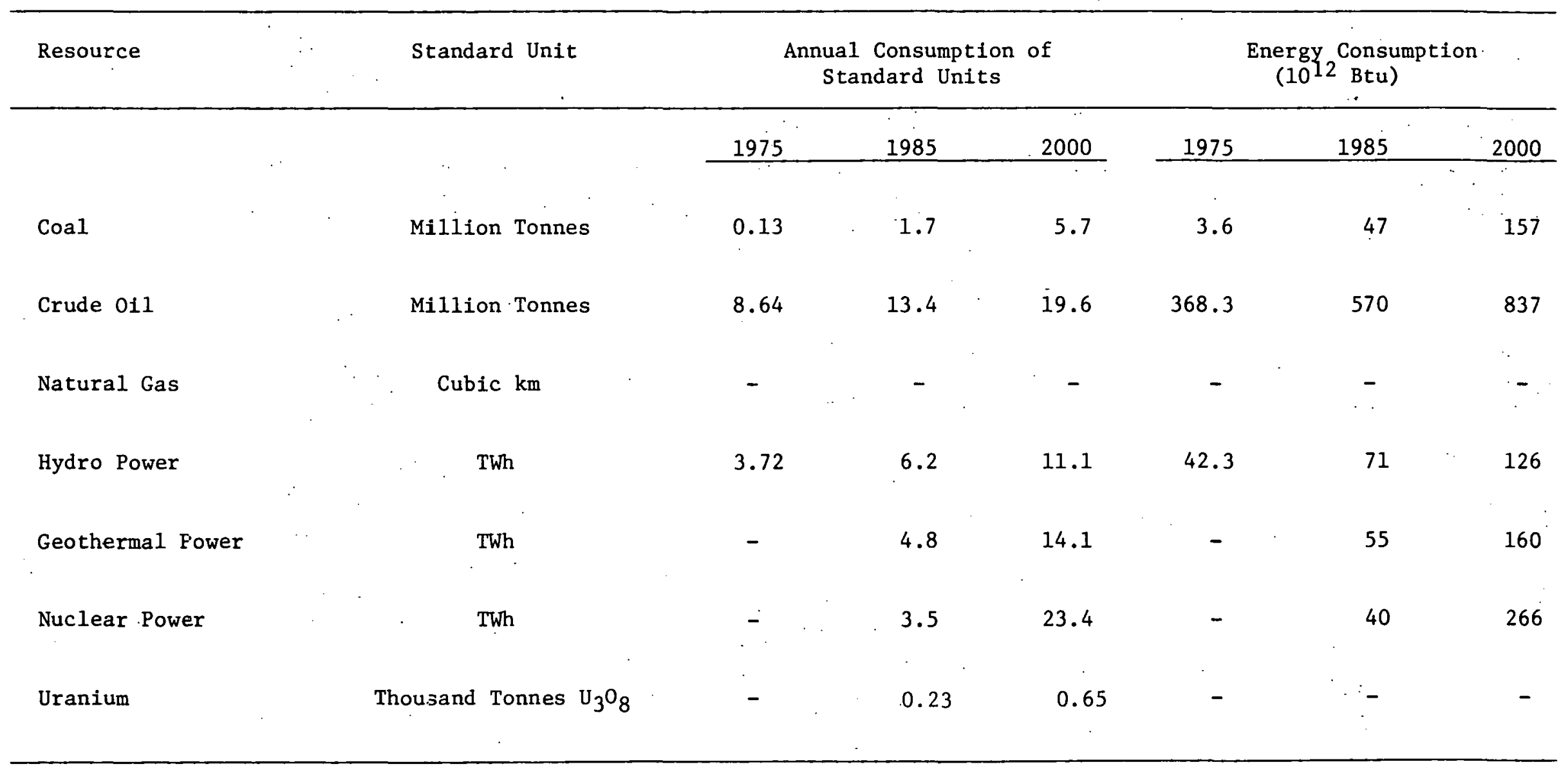


21.2 NUCLEAR HISTORY, CAPABILITY, COMMITTMENT AND TRENDS

\section{COMMERCIAL NUCLEAR POWER PLANTS}

Tab1e 21.2.1

\begin{tabular}{|c|c|c|c|c|c|c|}
\hline $\begin{array}{c}\text { Facility } \\
\text { Name }\end{array}$ & Utility & Vendus & $\begin{array}{c}\text { Facility } \\
\text { Iype }\end{array}$ & $\begin{array}{l}\text { Capacity } \\
\text { (NW ileL) }\end{array}$ & 3Lalus: & COD \\
\hline PNPP-1 & PNPP & Westinghouse & PWR & 626 & $\mathrm{U}$ & Jul 1983 \\
\hline
\end{tabular}

* O-Operational; U-Under Construction; P-Planned 
PROJECTED NUCLEAR GENERATING CAPACITY MWe (net)

Tab1e 21.2.2

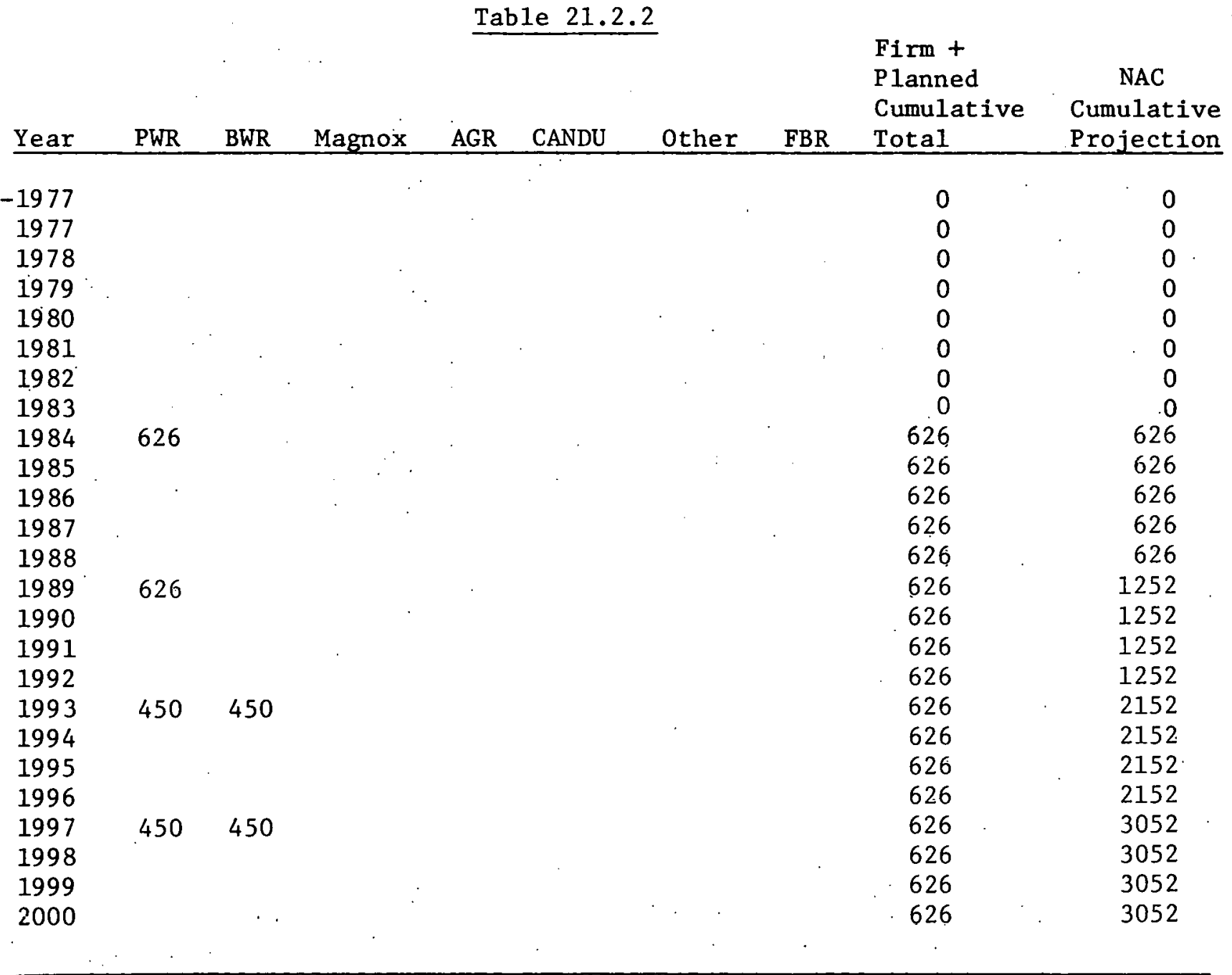


NUCLEAR REACTOR VENDORS

Overview

The Philippines have no indigenous reactor vendors. It is expected that future reactors will be obtained from foreign vendors. It is to be presumed that most future reactors would be imported from the United States.

Nuclear Reactor Vendor Support Industries

There are no major reactor vendor support industries in the Philippines.

NUCLEAR FUEL CYCLE FACILITIES

\section{Ovcrview}

At present there are no commercial fuel cycle facilities in the Philippines. The nation has evidenced desire to develop some fuel cycle facilities in the Iuture, and is in fact beginning a modest uranium exploration program. The Philippines note that such facilities would require regional partners, financing, technically trained personnel, and time.

NUCLEAR DEVELOPMENT OUTLOOK SUMMARY

Vested Interests in Current Reactor Technologies and Fuel Cycles

There are no industrial vested interests in any reactor type or fuel cycles. As PNPP-1 operates and further reactor commitments bccome firm, such interests may develop.

Current Trends in Nuclear Development Programs

'l'he Philippines are just beginning to obtain nuclear technology. A uranium exploration program is just being initiated. 
PROFESSIONAL LABOR FORCE PROFILE

Table 21.3.1

Not Available

KEY TECHNICAL EDUCATIONAL RESOURCES

Table 21.3.2

\section{Institution}

Aquinas University

Araneta University Foundation

Bicol University

Central Luzon State University

Central Philippine University

De la Salle College

Divine Word University

Feati University

Mindanao State University

National University

Notre Dame University of Cotabato

Silliman University

Southwestern University.

University of Baguio

University of the East

University of Eastern Philippines

University of Mindanan

University of Negros Occidental -

Recoletos

\section{Location}

Legazpi City

Victoneta Park, Rizal

Regan Barracks, Regazpi City

Munez, Nueva, Ecija

Iloilo City

Manila

Tacloban City

Santa Cruz, Manila

Marawi City

Sampaloc, Manila

Cotabato City

Dumaguete City

Villaznar, Cebu City

Baguio City

Manila

Catarman, Samar

Davao City

Bacolod City 
KEY GOVERNMENTAL NUCLEAR RESEARCH ORGANIZATIONS

Table 21.3.3

Name

Philippine Atomic Energy

Commission

\section{Location}

Quezon City

\section{Main Activities}

sole authority for promotion and regulation of Philippiut nut 1 rit $r$ activities. Resparch in arcas of:

-food supply

-energy - $\mathrm{U}_{3} 0_{8}$ resources - U308 mine/mill

-engineering

-medicine

-environmental studies

-basic research 
KEY PRIVATE NUCLEAR RESEARCH ORGANIZATIONS

Table 21.3.4

Name

Owner

Location

Main Activities

Not Applicable 


\section{RESEARCH AND TEST REACTORS}

List of Reactors

Table 21.3.5
Facility

Name

PRR-1

\section{$\underline{\text { Location }}$}

Quezon City
Owner

PAEC
Constructor

G.E.

\section{Facility \\ Facility Status} Type

research pool MW(th) Status* COD

1

0

1963 
INDIGENOUS CAPABILITY TO DESIGN AND SUPPLY RESEARCH AND TEST REACTORS AND FUEL SERVICES Summary of Reactor Orders by Vendor and Country

Vendar

Country

Facility

Name

Table 21.3.6

Facility Facility Status Scope of Type MW(th) Status* COD Services

Not Applicable 
SUMMARY OF IUEL SERVICES FOR RESEARCH AND TEST REACTOES

Table 21.3:7

Facility

Name
Location

Facility

Type.

$\frac{\text { Capacity Status }}{\text { MT/YR }}$

Year

Shareholdings

Not Applicable

* O-Operational; U-Uncer Cons=ruction; P-Planned; S-Shutdown 


\subsection{ECONOMIC RESOURCES FOR NUCLEAR POWER DEVELOPMENT}

\section{ECONOMIC DATA PROFTLE}

Table 21.4.1

$\begin{array}{llll}\text { GNP (Current million } \$) & -20,600(1977) & \text { Inflation Rate } & -7 \%(1977) \\ \text { Exports (million \$) } & -3,150(1977) & \text { Imports (million } \$) & -3,914(1977) \\ \text { Per Capita Income (\$) } & -462(1977) & \text { Disposable Income (\$) }-333(1975) \\ \text { Monetary Unit } & - \text { Pesos } & \text { Exchange Rate (/US\$) }-7.36(10 / 78) \\ \text { Population (million) } & -45.0(1977) & \end{array}$

21.4.2 GOVERNMENTAL NUCLEAR ENERGY R\&D BUDGET

Pesos (Thousands)

$\begin{array}{llllll}1977 & \begin{array}{c}1978 \text { to } \\ 1980\end{array} & \begin{array}{c}1981 \text { to } \\ 1986\end{array} & \begin{array}{c}1987 \text { to } \\ 1990\end{array} & \begin{array}{c}1991 \text { to } \\ 2000\end{array} & \begin{array}{c}\text { Total } \\ 1977-2000\end{array} \\ 11,440 & 44,980 & .102,960 & 161,660 & 688,100 & 1,009,140\end{array}$

7.43 Pesos/US Dollar (1976)

Approximately $40 \%$ of Philippine Atomic Energy Commission (PAEC) funding is used for $R \& D$, about $24 \%$ of the total PAEC expenditures is expected to come from external sources (such as the Energy Development Board and IAEA); d11 is to be used on R\&D. 
GOVERNMENTAL SUPPORTED NUCLEAR R\&D INDUSTRY, UNIVERS ITIES

AND NATIONAL LABORATORIES

Table 21.4.3

Industry

University or

Laboratory

Program

Area

Training in Nuclear

Technology

National University

\begin{tabular}{c} 
Budget \\
S(Millions) \\
\hline
\end{tabular}

Key

$\underline{\text { Personnel }}$

The main bodies involved with the implementation of nuclear power studies are:

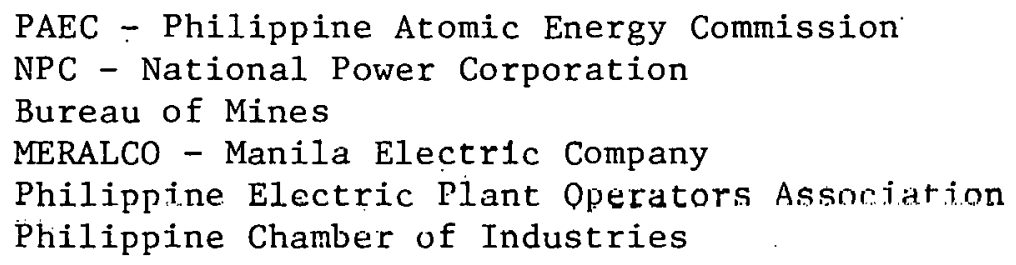

21.4.4 ROLE OF PRIVATE INDUSTRY IN NUCLEAR ENERGY R\&D

Virtualiy all nuclear R\&D is conducted by the government, specifically PAEC. Private efforts are encouraged nnly in the devclopment of Philippine uranium resources and production capability.

\section{ECONOMIC PROFILE: OF REACTOR VENDORS AND FUEL CYCLE FACILITIES}

Table 21.4 .5

Name

Share Capital

Assets

Ealca

Not Applicable 


\subsubsection{MODE OF FINANCING OF NUCLEAR POWER PLANTS}

The foreign investment is expected to come from loans from international financing organizations, while the domestic investment can be met either by outright government contribution or normal utility corporate financing.

PNPP-1 - $\$ 534$ million loan from U. S. Eximbank and a consortium of commercial banks.

- \$367 million bond issue guaranteed by U. S. Eximbank, floated in U. S. capital markets.

\subsection{GOVERNMENT COMMITMENT AND ROLE IN NUCLEAR POWER DEVELOPMENT}

\subsubsection{ENERGY POLICY - BASIC LEGISLATION}

Commonwealth Act No. 120.(1936) - created the National Power Corporation, nationalized hydroelectric industry.

Republic Act 2067 (1958), amended by Republic Act 3589, and Presidential Decree No. 606 - created by Philippine Atomic Energy Commission (PAEC).

Republic Act 5207 (1968) - guiding policy on development and use of nuclear energy, liability for nuclear damage.

Presidential Decree No. 1200 (1977) - approves "Five-Year Philippine Development P1an, 1978-1982, including the Ten-Year Development Plan, 1978-1987," which includes National Energy Policy.

Presidential Decree No. 1206 (1977) - creates Department of Energy, brought NPC and PAEC into Department of Energy. 


\subsubsection{GOVERNMENTAL STRUCTURE FOR NUCLEAR ENERGY POLICY AND R\&D}

The government is a parliamentary republic headed by President and Prime Minister Ferdinand E. Marcos. Martial law was imposed by Marcos in 1972, and a new constitution went into effect in 1973. A general election was held in April 1978, and in June 1978, a National Assembly consisting of 200 members was formed. Martial law has remained in effect.

Nuclear Energy Policy and R\&D is established and operated within the Department of Energy and specifically by the Philippine Atomic Energy Commission

ORGANIZATIONAL CHART

DEFAR'IMEN'L OH' ENERGY

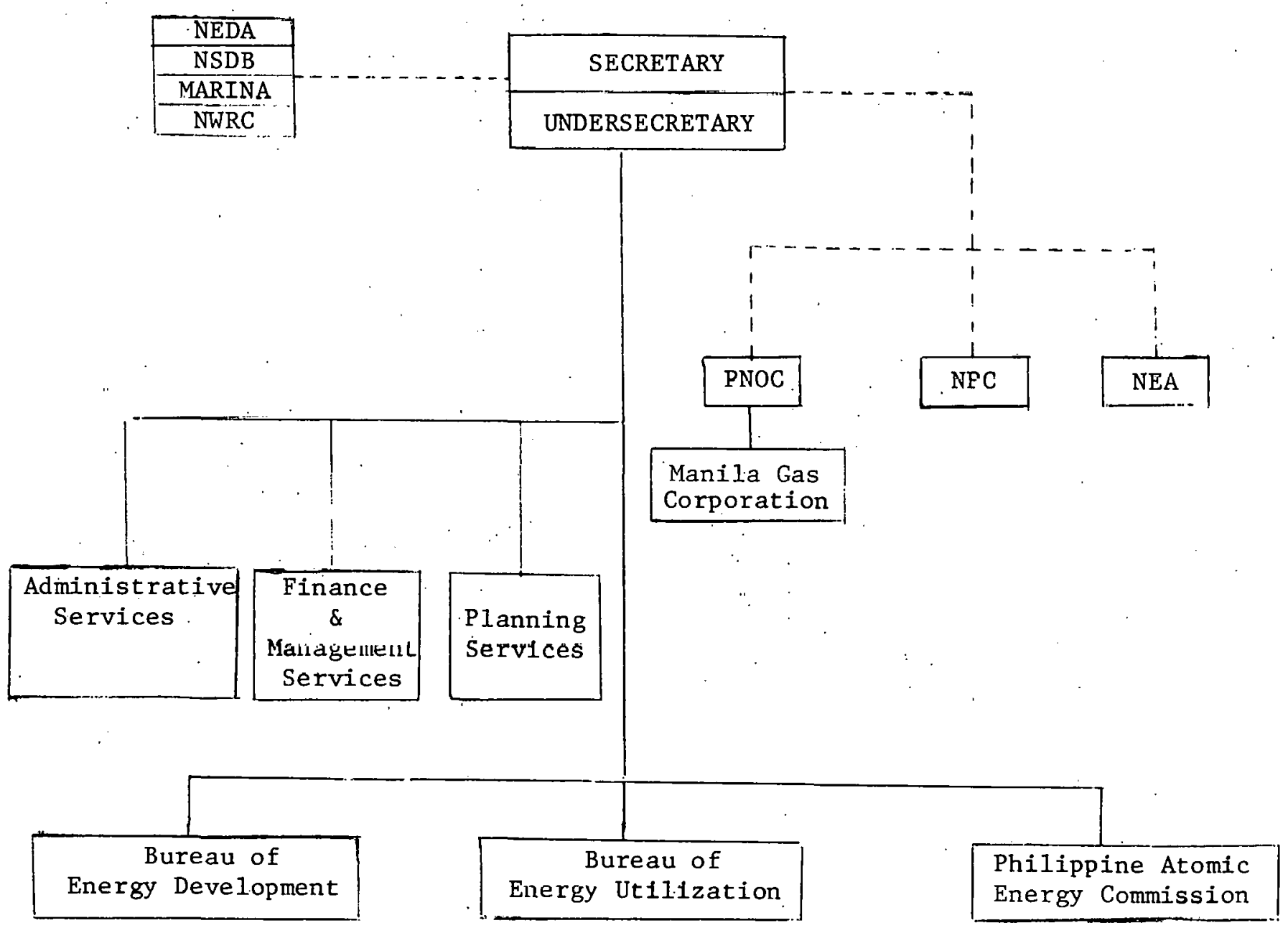


ORGANIZATIONAL CHART

DEPARTMENT OF ENERGY

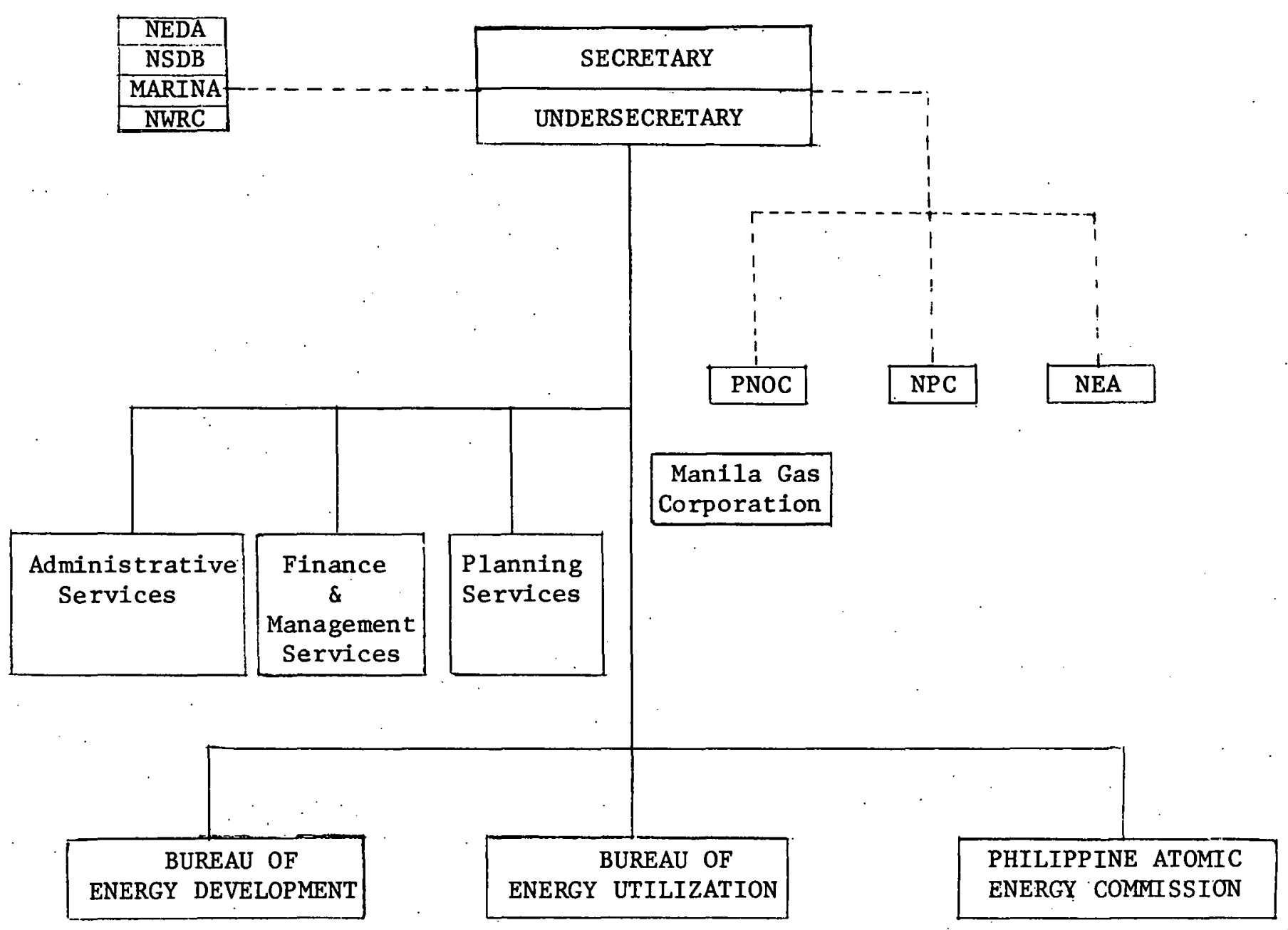




\subsubsection{NUCLEAR ENERGY POLICY AND OBJECTIVES}

Nuclear energy policy and objectives are contained within the broad outlines of the National Energy Policy. As discussed at the earlier 1976 Pacific Basic Conference, the Plan calls for installation of up to eleven nuclear units during this century, development of indigenous uranium resources, uranium production capability, and training of needed technical personnel.

\subsubsection{NUCLEAR ENERGY R\&D - STATUS AND OUTLOOK \\ Of the six nuclear R\&D sub-programs, only one - Energy and Water Resources - is specifically directed towards nuclear energy. This effort has successfully produced $1 \mathrm{ab}$ scale quantities of $\mathrm{U}_{3} \mathrm{O}_{8}$ from Philippine ore, and carried out various activities directed towards delineating the indigenous uranium resources. It is expected that these efforts will result in partial indigenous ( $\sim 300 \mathrm{ST} \mathrm{U}_{3} 0_{8}$ ) supply of uranium during the early to mid-1980's.}

\subsubsection{NUCLEAR ENERGY R\&D - PRTORITIES}

Established nuclear energy priorities are:

Initiate and undertake $R \& D$ using radiation, radioisotopes and nuclear techniques.

Train technical manpower for present and projected nuclear activities.

Establishment of necessary 1 ahnratories and pilot plaijls:

Local manufacture of nuclear instruments.

\subsubsection{ROLE OF GOVERNMENT IN NUCLEAR FACILITIES CONSTRUCTION AND OPERATION \\ Construction -. The government provides hasic elieryy planning, financing, regulation, and personal training. \\ Operation - The government provides regulation (PAEC) and direct operation (NPC).}


21.6 NON-NUCLEAR ENERGY FACILITIES AND FUEL SUPPLY

PHILIPPINES- 23 


\section{Table $\quad 21.6 .1$}

\section{Facility}

Name

Rockwe11 1-5

Rockwe11 6-8

Tegon $1-2$

Gardnor 1-2

Snyder 1-2

Bat aem 2

Binga

Angat

Montelibano I

Montelibano II

Patabanyan

Malaya 2

Kalayaan $1+2$

Utili=y
Owner
Meralco
Meralca
Meralca
Meralca
Meralca
Meralce
Meralca
Meralcc
Meralcc.
Meralcc
Meralcc
Meralcc
Meralcc

Utili:y/

Location

\begin{tabular}{c} 
Facility \\
Type \\
(Fue1 Type) \\
\hline
\end{tabular}

$0 i 1$

Oi1

Oi 1

Oi1

$0 i 1$

OiI

Hydro

Hydro

oil

$0 i 1$

Hyddro

oil

Hydro
Capacity (MWe net)

$\underline{\text { Status* }}$ COD

125

o 1958

180

$0 \quad 1963$

200

$0 \quad 1966$

350

$0 \quad 1970$

500

0 1972

150

$0 \quad 1977$

100

212

300

300

100

294

300

$0 \quad 1960$

$0 \quad 1974$

$0 \quad 1977$

0 $\quad 1977$

U $\quad 1981$
$0 \quad 1968$

U $\quad 1979$

* O-Operational; U-Under Construction; P-Flanned; S-Shutdown 


\section{ENERGY GENERATION FACILITIES IN EXISTENCE AND FIRMLY PLANNED PRODUCING 100 MWe (net)}

\section{Table 21.6.1 (Continued)}

Facility

Name

Tabu

Tiwi 1-4

Mak-Ban 1-4

Abulog I 1-4

Abulog I 5-8

Abulog I

Geo 9-10

Abulog I

Geo 11-12

Chico 4

Chico 2

Abulog II

Cebu Diese1

$1+2$

Visayas

Region

Cebu Therma1

$1+2$

\footnotetext{
* O-Operational; U-Under Constructior; P-Planned; S-Shutdown
}

\begin{tabular}{|c|c|c|c|}
\hline $\begin{array}{c}\text { Facility } \\
\text { Type } \\
\text { (Fuel Type) } \\
\end{array}$ & $\begin{array}{l}\text { Capacity } \\
\text { (MWe net) }\end{array}$ & Status* & COD \\
\hline Hydro & 400 & $\mathrm{U}$ & 1984 \\
\hline Geothermal & 220 & $\mathrm{P}$ & $1978-1983$ \\
\hline Geothermal & 220 & U & $1979-1983$ \\
\hline Hydro & 200 & $P$ & 1985 \\
\hline Hydro & 200 & $\mathrm{P}$ & 1987 \\
\hline Geothermal & 110 & $\mathrm{P}$ & 1985 \\
\hline Geothermal & 110 & $\mathrm{P}$ & 1986 \\
\hline Hydro & 300 & $\mathbf{P}$ & 1987 \\
\hline Hydro & 360 & $\mathrm{P}$ & 1989 \\
\hline Hydro & 300 & $P$ & 1989 \\
\hline 011 : & 140 & $0-U$ & $1977-79$ \\
\hline Thermal & 100 & $\mathrm{U}$ & $1980-83$ \\
\hline
\end{tabular}




\section{ENERGY GENERATION FACILITIES IN EXISTENCE AND FIRMLY PLANNED PEODUCING 100 MWe (net)}

\section{Table 21.6.1 (Continued)}

Factlity

Name.

Sipalay D

1-9

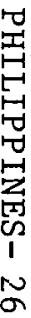

Dauin $1+2$

Tongonan

$1-4$

Agus 1

Agus 2

Agus 3

Agus 4

Agus 5

Agus-Diese 1

Plant 1-6

* 0-Operational.

\section{Location}

Ut1lity/

Cwner

Negros Grid

$\underline{\text { Vendor }}$

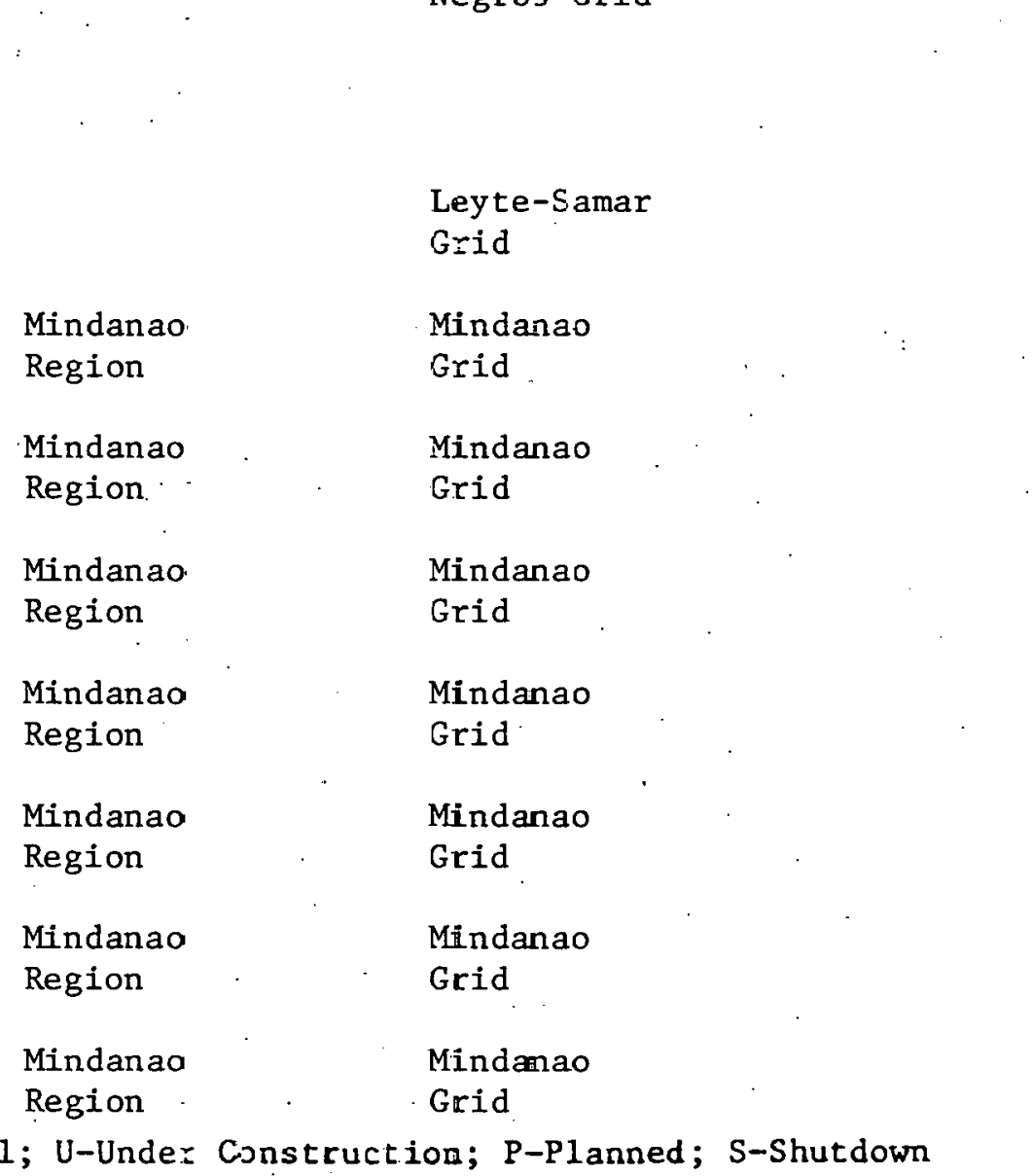

\begin{tabular}{|c|c|c|c|}
\hline $\begin{array}{c}\text { Facility } \\
\text { Type } \\
\text { (Fuel Type) } \\
\end{array}$ & $\begin{array}{l}\text { Capacity } \\
\text { (MWe net) }\end{array}$ & Status* & COD \\
\hline Jil & 162 & $\mathrm{U}$ & $1979-80$ \\
\hline Jeothermal & 110 & $\mathrm{P}$ & $1981-84$ \\
\hline \multirow{3}{*}{ Jeothermal } & 220 & $\mathrm{P}$ & $1981-84$ \\
\hline & 100 & $\mathrm{U}$ & 1980 \\
\hline & 180 & $\mathrm{U}$ & 1978 \\
\hline & 150 & $\mathrm{P}$ & 1982 \\
\hline 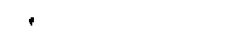 & & & \\
\hline & 50 & 0 & 1977 \\
\hline \multirow{3}{*}{ ' } & 150 & $P$ & 1984 \\
\hline & 45 & $\mathrm{U}$ & 1980 \\
\hline & 108 & $\mathrm{U}$ & 1978 \\
\hline
\end{tabular}


ENERGY GENERATION FACILITIES IN EXISTENCE AND FIRMLY PLANNED PRODUCING 100 MWe (net)

Table 21.6.1 (Continued)

\begin{tabular}{|c|c|c|c|c|c|c|c|}
\hline $\begin{array}{l}\text { Facility } \\
\text { Name }\end{array}$ & Location & $\begin{array}{l}\text { Utillty } \\
\text { Owner }\end{array}$ & Vendor & $\begin{array}{c}\text { Facility } \\
\text { Type } \\
\text { (Fuel Type) } \\
\end{array}$ & $\begin{array}{l}\text { Capac1ty } \\
\text { (MWe net) }\end{array}$ & Status* & COD \\
\hline $\begin{array}{l}\text { Agus-Geo- } \\
\text { thermal } 1+2\end{array}$ & $\begin{array}{l}\text { Mindanao } \\
\text { Region }\end{array}$ & $\begin{array}{l}\text { Mindanao } \\
\text { Grid }\end{array}$ & & & 110 & $\mathrm{U}$ & 1980 \\
\hline $\begin{array}{l}\text { Agus - Geo- } \\
\text { thermal } 3\end{array}$ & $\begin{array}{l}\text { Mindanao } \\
\text { Region }\end{array}$ & $\begin{array}{l}\text { Mindanao } \\
\text { Grid }\end{array}$ & & & 55 & $P$ & 1985 \\
\hline $\begin{array}{l}\text { Agus - Geo- } \\
\text { thermal } 4\end{array}$ & $\begin{array}{l}\text { Mindanao } \\
\text { Region }\end{array}$ & $\begin{array}{l}\text { Mindanao } \\
\text { Grid }\end{array}$ & & & 55 & $\mathbf{P}$ & $\begin{array}{l}\text { Beyond } \\
1985\end{array}$ \\
\hline $\begin{array}{l}\text { Agus - Thermal } \\
\text { Plant } 1\end{array}$ & $\begin{array}{l}\text { Mindanao } \\
\text { Region }\end{array}$ & $\begin{array}{l}\text { Mindanao } \\
\text { Grid }\end{array}$ & & & 150 & $\mathbf{P}$ & 1982 \\
\hline Pulangui 2 & $\begin{array}{l}\text { Mindanao } \\
\text { Region }\end{array}$ & $\begin{array}{l}\text { Mindanao } \\
\text { Grid }\end{array}$ & & & 250 & $\mathrm{P}$ & $\begin{array}{l}\text { Beyond } \\
1985\end{array}$ \\
\hline Pulangui 3 & $\begin{array}{l}\text { Mindanao } \\
\text { Region }\end{array}$ & $\begin{array}{l}\text { Mindanao } \\
\text { Grid }\end{array}$ & & & 200 & $\mathbf{P}$ & 1985 \\
\hline Pulangui 5 & $\begin{array}{l}\text { Mindanao } \\
\text { Region }\end{array}$ & $\begin{array}{l}\text { Mindanao } \\
\text { Grid }\end{array}$ & & & .40 & & $\begin{array}{l}\text { Beyond } \\
1985\end{array}$ \\
\hline
\end{tabular}

* 0-Operational; U-Under Construction; P-Planned; S-Shutdown 
SUMMARY OF ENERGY GENERATION FACILITIES IN EXISTENCE AND PLANNED

Table 21.6.2

$\begin{array}{lc}\text { Year } & \text { Capacity - MWe (net) } \\ 1975 & 3,019 \\ 1980 & 4,769 \\ 1985 & 7,573 \\ 1990 & 9,005 \\ 1995 & \\ 2000 & \end{array}$


LISTING OF FUEL SUPPLY FACILITIES IN EXISTENCE AND FIRMLY PLANNED

Table 21.6.3

Facility

Name

Location
Mindanao
Cebu

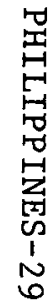

* O-Operational; U-Under Construction; P-Planned; S-Shutdown ** Coal - million tonnes/year 
Table 21.6 .4

RESOURCE

COAL (million tonnes)

Indigenous Supply

Imports

Exports

CRUDE OIL (million tonnes)

Indigenous Supply

Impul Ls

Exports

SHALE OIL (million tonnes)

Indigenous supply

Imports

Exports

NATURAL GAS (cubic kilometers)

Indigenous Supply

Imports

Fiports

URANIUM (kilotonnes $\mathrm{U}_{3} \mathrm{O}_{8}$ )

Indigenous Supply

Imports

Exports
1985

2000

0.07

0.08

1.63

5.62

--

0

13.4

0

19.6

--

0

0

$\begin{array}{cc}0 & 0 \\ -- & - \\ -- & -\end{array}$

0

0

.23

.65

0

0 
SECTION 22

SOUTH AFRICA 


\subsection{PROJECTED INDIGENOUS ENERGY RESOURCES, DEMANDS AND RELATED INFORMATION}

\section{INDIGENOUS RESOURCES}

South Africa possesses $75 \%$ of all African coal resources, and these are principally high-ranking. Total resources have increased from the 1969 survey value (ref. 1.1) of 44,339 million tonnes to 82,018 million tonnes (ref. 1.2). The economically recoverable amount is now put at 13,060 million tonnes (ref. 1.2) compared with 10,584 million tonnes (ref. 1.1).

No resources of crude or shale oil have been reported in Ref. 1.1 or 1.2 . However, the 1977 World Energy Conference (Ref. 1.8) reported 20.2 million tonnes as reserves.

A small quantity of offshore natural gas has been identified on the continental shelf but no production has taken place and the economically recoverable amount is unknown.

Africa produces less than $0.1 \%$ of world hydro-power output but this is almost exclusively South African. Economically recoverable reserves are put at 2.4 TWh annually and major developments are planned for both the Orange and Tugela Rivers. No data is available for theoretical hydro-power output for South Africa.

South Africa has one of the free-world's larger resources of uranium, 495.3 thous and tonnes. Most is found as a by-product of gold mining.

No geothermal plants have been reported.

\section{ENERGY SUPPLY}

Figures for supply, import and export are not generally available.

Export quantities of coal (2.8 million tonnes) were obtained by private communication.

Figures for oil movement are classified though reference 1.5 gives an estimated figure for oil imports.

A11 uranium produced in 1975 was stockpiled or exported.

\section{PATTERNS OF ENERGY USE}

Coal is consumed in all sectors, though its principal use is for electrical generation.

Petroleum is not used for electrical generation (Paper 1.2-14, ref. 1.7). 
A11 sectoral data for Table 22.1.3 come from Paper 1.2-14, reference 1.17, and are for 1972. The figures given cannot therefore be compared directly with those of any other table.

The figures for utility electricity distributed come from reference 1.41 with an allowance for private generation and are for the year 1975 .

\section{FORECASTS OF ENERGY SUPPLY AND DEMAND}

The primary energy and electricity demand forecasts for South Africa presented in Table 22.1.4 indicate an average demand growth rate from 1976 to 2000 of between $1.5 \%$ and $3.2 \%$ for total energy and $2.4 \%$ to $4.6 \%$ for electricity. During the period.1965 to 1974, ernnomic growth avcragcd $5.2 \%$ (ref. 1.43) while energy and electricity consumption increased by an average $6.6 \%$ and $8.6 \%$ per year respectively (refs. 1.5 and 1.44 ).

A forecast of energy demand in South Africa presented at the 1974 World Energy Conference (Paper 1.2-14, ref. 1.7) estimated a total primary energy in 2000 of approximately $4,900 \times 10^{12} \mathrm{Btu}$ (total useful energy consumption $1.9 \times 10^{18} \mathrm{~J}$ and an average conversion efficiency of $37 \%$ ). The electricity demand forecast for 2000 was 232 TWh.

The breakdown of energy demand into the various sources of supply presented in Table 22.1.5 shows that the relative contribution of each source of energy remains virtually unchanged throughout the period 1985 to 2000 except for the expansion of nuclear power which slightly reduces the importance of coal. The increase in demand between 1975 and 1985 is met mainly by an increase in oil imports and nuclear power. 
INDIGENOUS ENERGY RESOURCES

Table 22.1.1

Economically
Recoverable Reserves

Uranium (thousand tonnes $\mathrm{U}_{3} \mathrm{O}_{8}$ )

Hydro Power (TWh/year)

Geotherma1 (TWh/year)

\author{
Crude 011 (million tonnes) \\ Shale 011. (million tonnes) \\ Natural Gas (cubic km) \\ Hard Coal (mfllion tonnes) \\ Soft Coal (million tonnes)
}

.

13,060

0

0

Total Indigenous

Resources

82,018

0

0

20.2

Not available

410.4

2.4

Not available
Location of Identifled Reserves 
ENER:GY SUPPLY 1975

Table 22.1.2

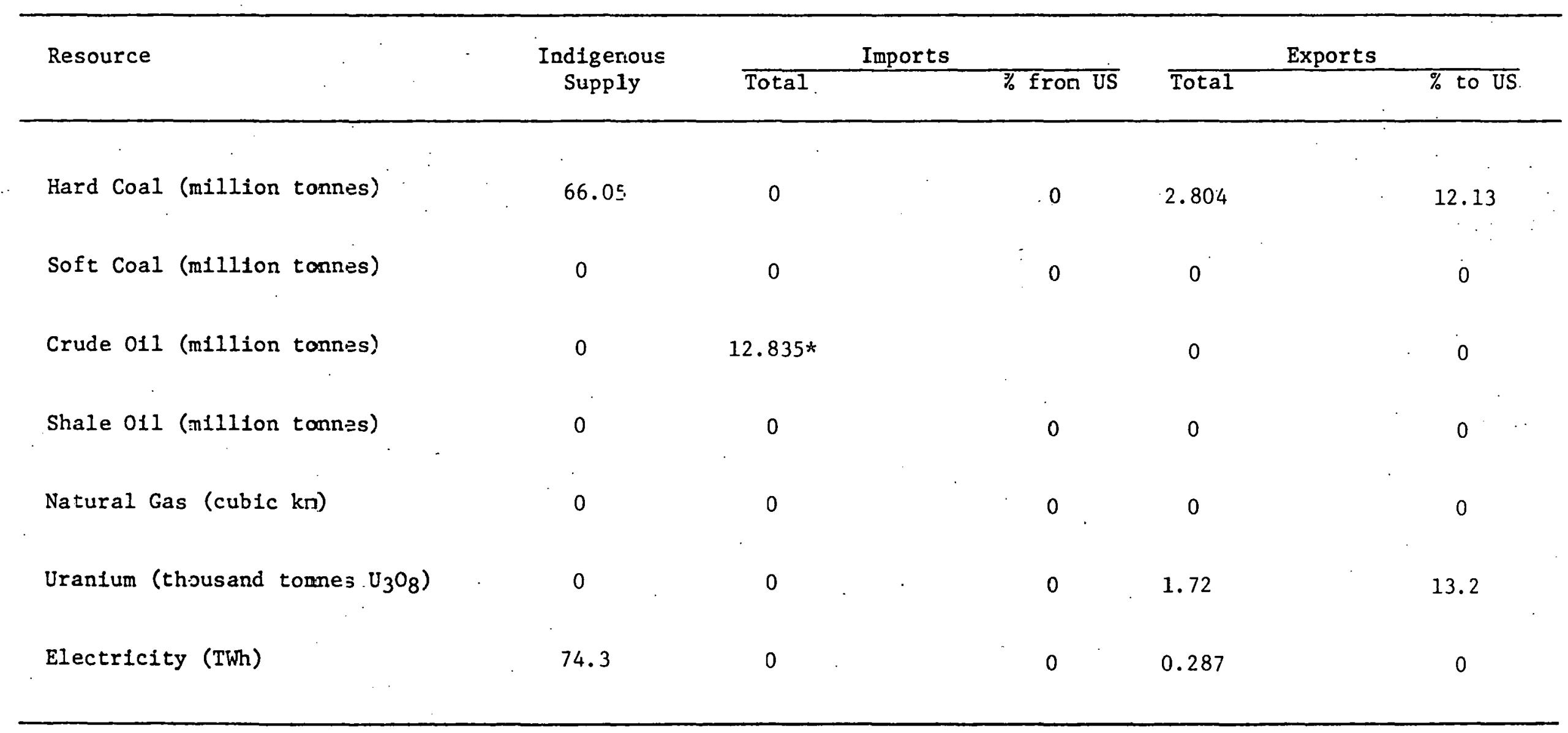

* UN Statistical office estimate 


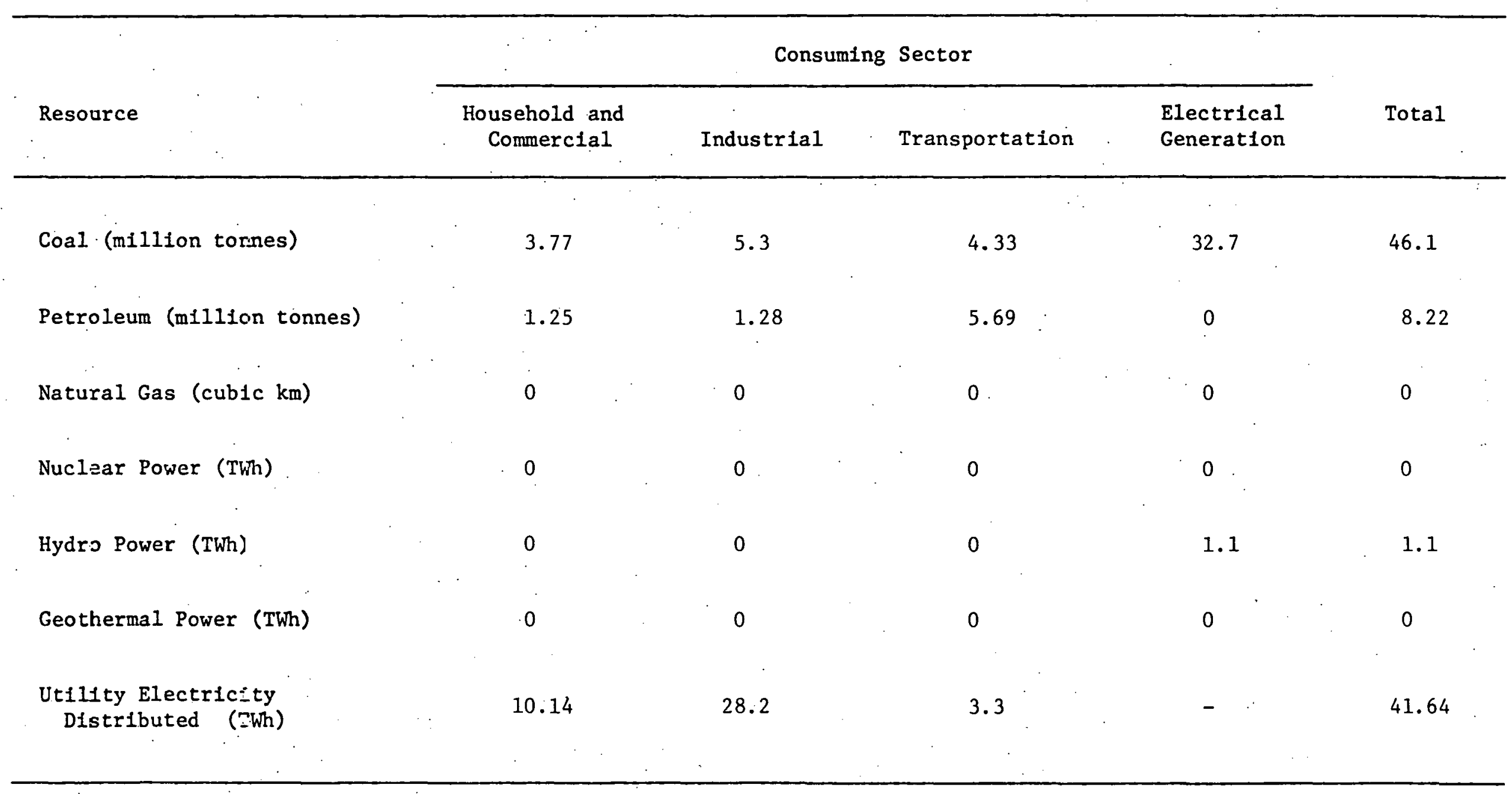


FORECASTS OI ANNUAL ENERGY DEMAND AND ELECTRICITI JEMAND

Table 22.1.4

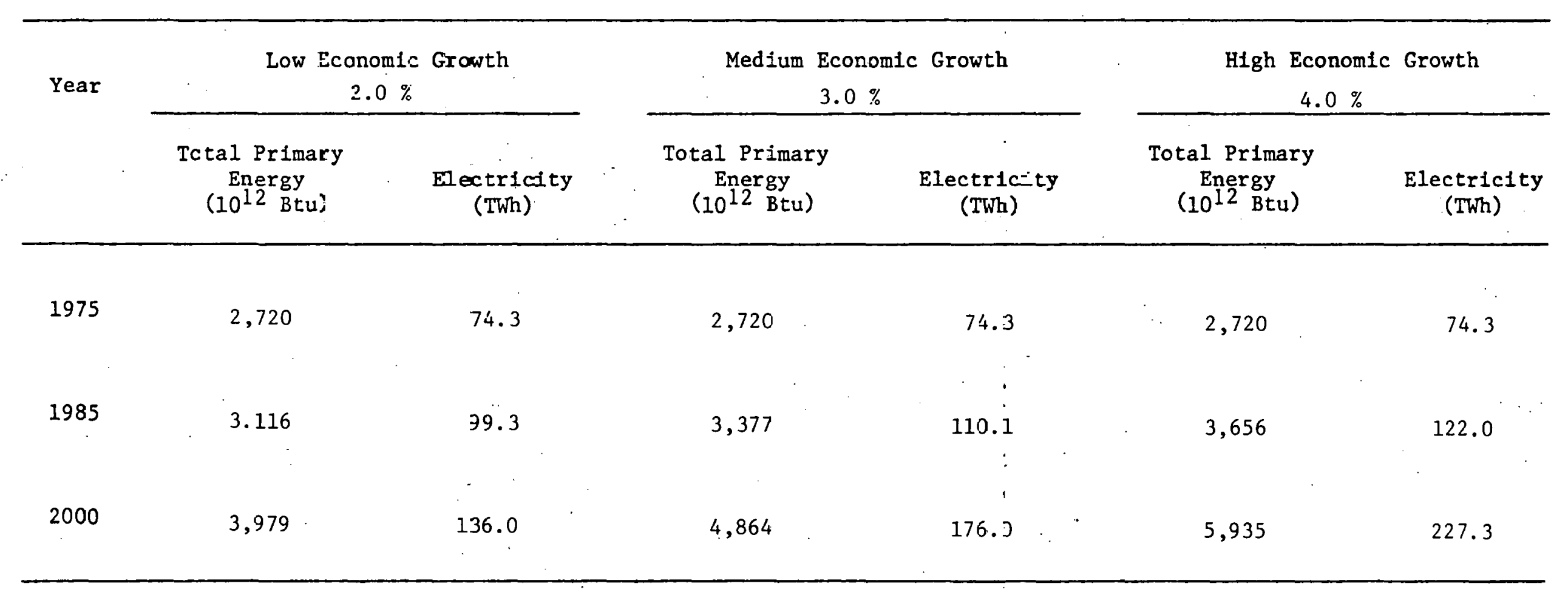


CONSUMPTION OF ENERGY RESOURCES

Table 22.1.5

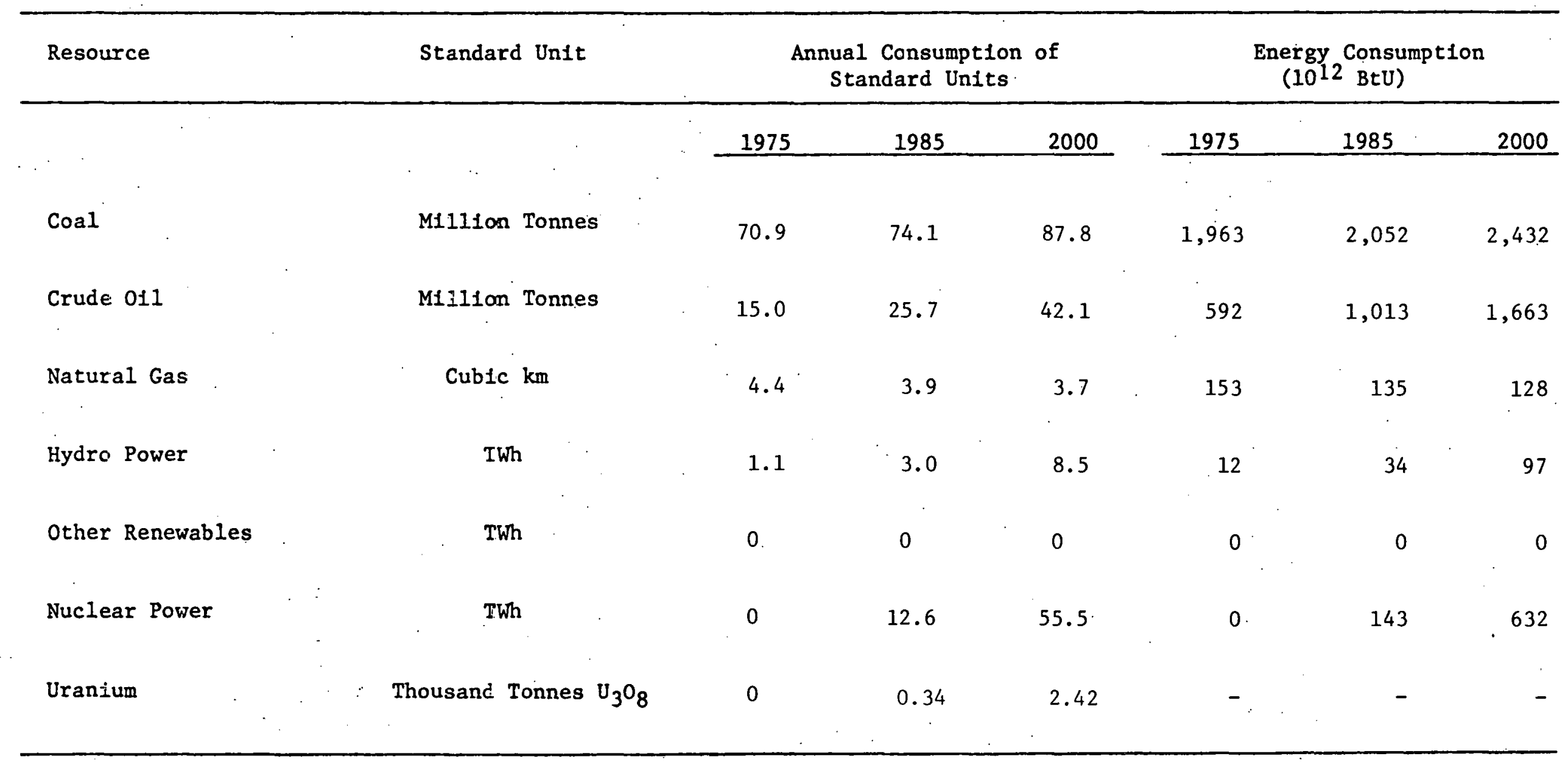


22.2 NUCLEAR HISTORY, CAPABILITY, COMMITMENT AND TRENDS

COMMERCIAL NUCLEAR POWER PLANTS

Table 22.2.1

\begin{tabular}{|c|c|c|c|c|c|c|}
\hline $\begin{array}{l}\text { Facility } \\
\text { Name }\end{array}$ & Uti $1 \mathrm{ity}$ & Vendor & $\begin{array}{c}\text { Facility } \\
\text { lype }\end{array}$ & $\begin{array}{l}\text { Lapacity } \\
\text { (MWe HeL) }\end{array}$ & BLalus A & EUN \\
\hline Koeberg-1 & $\begin{array}{l}\text { Electricity } \\
\text { Supply Commission } \\
\text { of South Africa }\end{array}$ & Framat ome & PWR & 922 & U & Jan 1983 \\
\hline Koeberg-2 & $\begin{array}{l}\text { Electricity } \\
\text { Supply Commission } \\
\text { of South Africa }\end{array}$ & Framatome & PWR & 922 & $\mathrm{U}$ & Jan 1984 \\
\hline
\end{tabular}

* O-Operational; U-Under Construction; P-Planned 
PROJECTED NUCLEAR GENERATING CAPACITY

MWe (net)

Table 22.2.2

\begin{tabular}{|c|c|c|c|c|c|c|c|c|c|}
\hline & & & & & & & & $\begin{array}{l}\text { Firm + } \\
\text { Planned } \\
\text { Cumulative }\end{array}$ & $\begin{array}{c}\text { NAC } \\
\text { Cumulative }\end{array}$ \\
\hline ear & PWR & BWR & Magnox & AGR & CANDU & SGHWR & Other & Total & Projection \\
\hline
\end{tabular}

$\begin{array}{rrr}\text { pre-1978 } & & \\ 1978 & & \\ 1979 & & \\ 1980 & & \\ 1981 & & \\ 1982 & & \\ 1983 & 922 & \\ 1984 & 922 & \\ 1985 & & \\ 1986 & & \\ 1987 & & \\ 1988 & & \\ 1989 & & \\ 1990 & & \\ 1991 & & \\ 1992 & 500 & 500 \\ 1993 & & \\ 1994 & 500 & 500 \\ 1995 & 500 & 500 \\ 1996 & 500 & 500 \\ 1997 & 500 & 500 \\ 1998 & 500 & 500 \\ 1999 & 500 & 500 \\ 2000 & 500 & 500\end{array}$

\begin{tabular}{rr}
0 & 0 \\
0 & 0 \\
0 & 0 \\
0 & 0 \\
0 & 0 \\
0 & 0 \\
922 & 922 \\
1844 & 1844 \\
1844 & 1844 \\
1844 & 1844 \\
1844 & 1844 \\
1844 & 1844 \\
1844 & 1844 \\
1844 & 1844 \\
1844 & 1844 \\
1844 & 2844 \\
1844 & 2844 \\
1844 & 3844 \\
1844 & 4844 \\
1844 & 5844 \\
1844 & 6844 \\
1844 & 7844 \\
1844 & 8844 \\
1844 & 9844 \\
& \\
\hline
\end{tabular}




\section{NUCLEAR REACTOR VENDORS}

\section{Overview}

There are no nuclear reactor vendors in South Africa. The purchase of the Koeberg units from France was politically motivated; however, future purchases from international vendors are highly speculative with no current preference.

\section{Nuclear Reactor Vendor Support Industries}

Major components for South African reactors are purchased abroad, and no major support industry is currently in place. However, as the nuclear program accelerates, the possibility for domestic support capability increases due to the highly independent economic philosophy in South Africa. 
NUCLEAR FUEL CYCLE FACILITIES

\section{Overview}

Uranium Production - South Africa has been and remains one of the largest uranium producers in the world. Uranium is produced, for the $\cdots$ most part, as a by-product or co-product of gold production. Uranium production peaked in 1959, with 26 mines and 17 mills in operation, producing 6,000 tonnes of uranium per year. Production dropped during the 1960's and early 1970's as a result of the decline in demand and the resulting low prices. In 1976, there were only eight mines in operation with a total production of about 3,000 tonnes. The price increase from 1974-1977 coupled with a generally weak market for gold has renewed activity in uranium recovery. New mills are being constructed and placed into operation, recovery of uranium from tailing dumps is being attempted, and exploration for uranium is being conducted in areas outside of the gold fields.

The extraction process used at the individual uranium mills yields a product in the form of an ammonium diuranate slurry which contains about $20 \%$ uranium by weight. The slurry is then processed at a central facility operated by the Nuclear Fuels Corporation of South Africa (NUFCOR), a private company owned by the mining companies. The NUFCOR operation includes blending, filtering, drying, and calcining the ammonium diuranate to produce $\mathrm{U}_{3} \mathrm{O}^{\circ}$

Uranium Enrichment - In 1970, the South African Atomic Energy Board (AEB) announced that it had developed a new uranium enrichment technique. The announcement was received with a great deal of scepticism, but the $A E B$ has continued its development work which, to date, includes the construction of a $6 \mathrm{MTSWU} / \mathrm{yr}$. pilot plant. A government corporation, the Uranium Enrichment Corporation of South Africa (UCOR), has been established and given responsibility for the development and commercialization nf uranium enrichment. The pilot plant is located at Valindaba, a site which is adjacent to the AEB's National Nuclear Research Center at Pelindaba. 


\section{CURRENT AND PLANNED FACIL_TIES}

Tab.le 22.2.3

\begin{tabular}{|c|c|c|c|c|c|c|}
\hline $\begin{array}{l}\text { Facility } \\
\text { Name }\end{array}$ & Lc=ation & $\begin{array}{c}\text { Facility } \\
\text { Type }\end{array}$ & $\mathrm{MT} / \mathrm{YR}$ & ststus* & Year & Shareholdings \\
\hline Vaal Reefs & $\begin{array}{l}\text { Klerksdorp Area, } \\
\text { Orange Free State }\end{array}$ & Uranium Production & $900 * *$ & $\mathrm{C}$ & & $\begin{array}{l}\text { Anglo American Corp. } \\
\text { of South Africa }\end{array}$ \\
\hline Western Deep Levels & $\begin{array}{l}\text { Far hest Rand, } \\
\text { Transvaal }\end{array}$ & Uranium Production & $160 * *$ & 0 & & $\begin{array}{l}\text { Anglo American Corp. } \\
\text { of South Africa }\end{array}$ \\
\hline President Brand & $\begin{array}{l}\text { O.F.S. Gold-Field, } \\
\text { Orange Free State }\end{array}$ & Uzanium Production & $100 * *$ & a. & . & $\begin{array}{l}\text { Anglo American Corp. } \\
\text { of South Africa }\end{array}$ \\
\hline Buffelsfontein & $\begin{array}{l}\text { K1 } \equiv \text { rksdorp Area, } \\
\text { Or } \triangleq n g e \text { Frae State }\end{array}$ & Ũanium Production & $560 * *$ & D & & $\begin{array}{l}\text { General Mining and } \\
\text { Finance Corp. }\end{array}$ \\
\hline West Rand Consolidated & $\begin{array}{l}\text { West Rand, } \\
\text { Transvaal }\end{array}$ & Uranium Production & $230 * *$ & J & & $\begin{array}{l}\text { General Mining and } \\
\text { Finance Corp. }\end{array}$ \\
\hline Blyvoorintzicht & $\begin{array}{l}\text { Far West Rani, } \\
\text { Transvaal }\end{array}$ & Uranium Production & $150 * *$ & 3 & & Rand mines \\
\hline Harmony & $\begin{array}{l}\text { O.F.S. Gold- } \text {-ield, } \\
\text { Orange Free State }\end{array}$ & Uranium Froduction & $450 * *$ & 1) & & Rand mines \\
\hline Hartebeestfontein & $\begin{array}{l}\text { Klerksdorp Azea, } \\
\text { Orange Free State }\end{array}$ & Uranium Eroduction & $370 * *$ & 1) & & $\begin{array}{l}\text { Anglo-Transvaal Consoli- } \\
\text { dated Investments Co. }\end{array}$ \\
\hline West Driefontein & $\begin{array}{l}\text { Far West Rand, } \\
\text { Transvaal }\end{array}$ & Uranium Froduction & $300 * *$ & 40 & & $\begin{array}{l}\text { Gold Fields of South } \\
\text { Africa }\end{array}$ \\
\hline NUFCOR & Suurbekom & Uranium Processing & 6,000 & 0 & 1952 & $\begin{array}{l}\text { Held by South African } \\
\text { mining companies }\end{array}$ \\
\hline UCOR & Valindaba & Uranium Enrichment & 6 MTSWU & $I$ & 1976 & South African Government \\
\hline
\end{tabular}

* O-Operationa1; U-Under Cons-ructicn; ?-Planned

** Estimated from recent production figures 
CURRENT AND PLANNED FACILITIES

Table 22.2.3 (cont.)

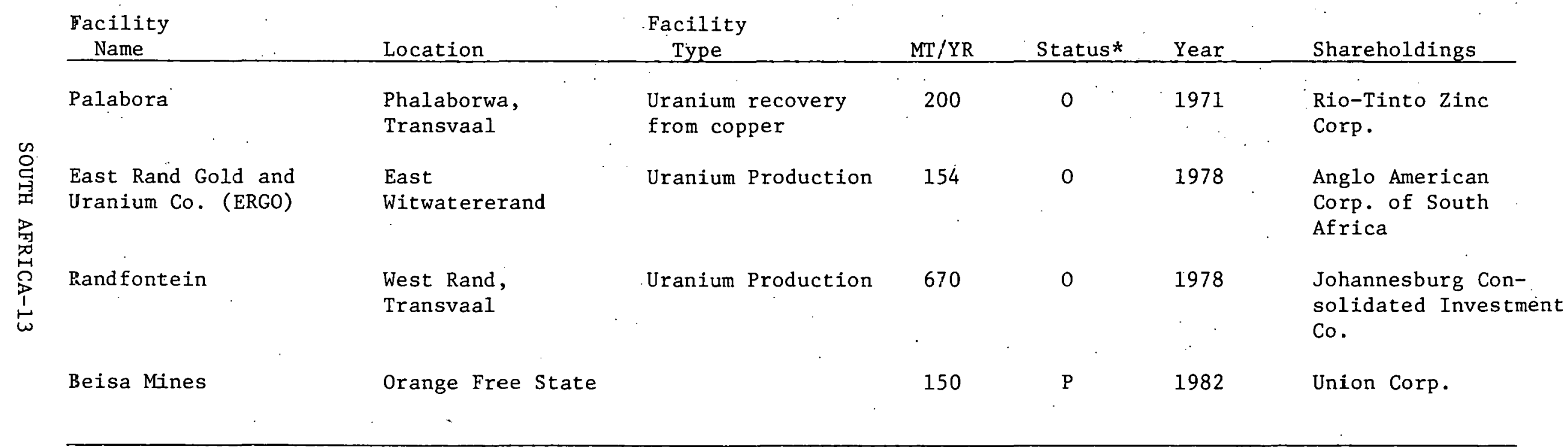

* 0-Operational; U-Under Construction; P-Planned 
Facilities: Gold/Uranium Mining

\section{Description of Operation}

Virtually all of South Africa's uranium is produced as a by-product or co-product of gold production $(99.7 \%$ of the total uranium produced to date has been in conjunction with gold mining operations, with the remaining $0.3 \%$ produced as a by-product of copper mining operations at Palabora).

The gold/uranium mining operations are massive; a typical mine employs 10,000-20,000 miners and operates around the clock, 365 days a year. All mines are underground, with shafts going as deep as two miles. The larger mines move more than 20,000 tons of ore and waste each duy. The gold and uranium are found together in the Witwatersrand gold reefs in thin beds within a body of quartzite and shale. The uranium is mostly in the form of microscopic grains of uranimite. Both the gold and uranium are exposed by fine milling the ore. In the recovery operation, the gold is extracted first by treatment with cyanide. The residues go to a separate plant where uranium is extracted by sulfuric acid. To separate the uranium a solvent extraction process, known as the Purlex process, is used. The product from this recovery step is ammonium diuranate, or ADU. The ADU from the individual mills is transferred to a central processing plant in a ADU/water slurry. The central processing plant is operated by the Nuclear Fuels Corporation, or NUFCOR, which is owned by the mining companies. NUFCOR receives the slurries, blends them together to assure the contigency of the final product, filters and dries the $\mathrm{ADU}$, then reduces the $\mathrm{ADU}$ to $\mathrm{U}_{3} \mathrm{O}_{8}$ in a coloring process.

Below is a discussion of the individual mining companies which are currently producing or may be producing uranium in the near finture.

\section{Africander Lease}

A total of $495 \mathrm{ST} \mathrm{U}_{3} \mathrm{O}_{8}$ were produced from 1954 to 1961, at which time uranium prodirtion ceased although gold production cunllnued until 1964. Currently, 9500 arres of mineral rights nre he 1.t and drilling has indicated the existence of a potentially economic deposit. It is possible that the mine could re-open utilizing the original shafts and operating at a level of $0.55-1.1$ million ST of ore per year by 1980 . If new shafts are sunk, production before 1983 would be unlikely. The dccision to reopen the mine will be based on results of the pilnt plant tests and the probability of obtaining suitable contracts. A feasibility study is being conducted based on a uranium-only mill with a capacity of 630 MTU/year. 


\section{Buffelsfontein}

The company is one of the larger uranium producers in South Africa. Approximately 5.5 million ST of uraniferous slimes have been accumulated and are ready for processing. Reserves are estimated to average $0.721 \mathrm{~b} \mathrm{U} \mathrm{U}_{8} / \mathrm{ST}$ ore. Estimated mine life is 16 years. Much of Buffelsfontein's future output is committed to contracts signed several years ago when lower prices prevailed. During 1976, modifications were made to the uranium plant and a new process introduced to improve the level of uranium recovery. Reserves at the Buffelsfontein mines are estimated to be on the order of 6.44 million tons.

\section{Free State}

The company has an entitlement to use the President Brand uranium plant which was put. into operation in 1977. Production is expected to increase from the current level of 1.2 million ST ore/year to 2.6 million ST by 1981. Mine life is estimated to be 16 years. Uranium grades recovered are likely to be about $0.301 \mathrm{~b} / \mathrm{ST}$.

\section{Harmony}

In 1974, the operations of Harmony, Virginia Gold Mining Co. Ltd., and Merriespruit Gold Mining Co. Ltd. were consolidated. Over the last three years, Harmony has processed over $50 \%$ of the total ore milled by the group. A stockpile of uraniferous slimes totaling 15.4 million tons has been accumulated and is ready for treatment. Mine life is estimated at 24 years and production is being increased from 5.7 million to 7.8 million tons per year by the end of. 1977. This increase is being accomplished by the operation of an extension to the Virginia plant from a capacity of 130,000 tons/month tn 160,000 tons/month. The expanded plant became operational in April 1977. Ore reserves are estimated at $17,44 \mathrm{~b}, 000$ tons of whlch $15,040,000$ tons are available for mining at an average uranium value of $0.42 \mathrm{lb} / \mathrm{ST}$. Uranium production since 1955 has totaled 12,520 $\mathrm{ST} \mathrm{U}_{3} \mathrm{O}_{8}$ for the group. The Merriespruit uranium plant is expected to come on-line by mid-1980. When fully operational, the plant will increase the mine's' $\mathrm{U}_{3} \mathrm{O}_{8}$ output by $16,500 \mathrm{sT} / \mathrm{month}$.

\section{Hartebeesfontein}

A mine life of 19 years has been estimated. The mill rate is expected to rise eventually to $3.4 \mathrm{million}$ tons/year. A stockpile of 4.1 million ST of uranium slimes is held by the company with an estimated value of $0.44 \mathrm{lb} / \mathrm{ST}$. 
The company has a three-year contract for the supply of uranium oxide which includes arrangements for a loan to the company. Recently, a long term contract has been signed which provides for a loan from the buyer for expansion. Capacity will be expanded from the current $275,000 \mathrm{ST} /$ month to $325,000 \mathrm{ST} / \mathrm{month}$ by 1980 .

\section{$\underline{\text { Randfontein }}$}

Formerly one of the largest uranium producers in South Africa, the company is opening a new Cooke mining section and production has been increased to 1.9 million $5 T / y e a r U_{30}$. Kandfontein has among the highest uranium reserves and ore grades for South Africa. Total ore reserves at the three Cooke shaft areas are estimated to be 72 millium $3 T$ of ore averaging from $0.441 \mathrm{~b} / \mathrm{ST}$ to $1.00 \mathrm{lb} / \mathrm{ST}$. The Millsite uranium recovery plant ( $110,000 \mathrm{ST} / \mathrm{month}$ capacity) was commissioned in August 1977 and will treat ore from the Cooke No. 1 and the new Cooke No. 2 shafts. Shaft sinking at the Cooke No. 3 area is planned as a second part of the expansion program, along with the commissioning of the $275,000 \mathrm{ST} / \mathrm{month}$ Cooke recovery plant. A total production of 880-990 ST/year is anticipated. Randfontein has a 10-year contract with the French CEA which includes the funding of capital expenditures by the CEA. The production target for 1979 is $760 \mathrm{MTU} /$ year with an eventual expansion to 1015 MTU/year. Full production is expected in early 1979.

\section{Southvaal}

Uranium reserves are reported to be large and rich, estimated at 110 million tons of ore. Mining was increased from a level of 1.65 million ST per year to 2.4 million ST at the end of 1976 and is slated to rise to 4.4 million by 1984 , with further increases later. A uranium plant is to be installed in the near future for the production of uranium oxide.

\section{$\underline{\text { Vaal Reefs }}$}

Vaal Reefs has the potential to become the largest uranium producer in South Africa. Vaal Reefs' own plant, along with its Western Reefs uranium mill has produced more $\mathrm{U}_{3} \mathrm{O}_{8}$ than any other mining company in South Africa. An accumulation of 20.2 million ST of uraniferous slimes will necessitate increased uranium capacity to handle the stockpile. Production is increasing from the current 1.65 million ST/yr. to 2.4 million by the end of 1977 and 4.4 million by 1984. This increase is due to an increase in capacity from $370,000 \mathrm{ST} /$ month to $790,000 \mathrm{ST} /$ month with the construction of a new 
$230,000 \mathrm{ST} / \mathrm{month}$ uranium plant at Vaal Reefs South. A long-term contract was signed in 1976 which is providing the front-end money for the production expansion. The annual capacity will be increased by $770 \mathrm{ST} \mathrm{U}_{3} \mathrm{O}_{8} /$ year to $2050 \mathrm{ST} \mathrm{U}_{3} \mathrm{O}_{8} /$ year by mid-1980. The expansion will allow treatment of current mine production, as well as uraniferous slimes.

\section{West Rand}

The uranium reserves are estimated at 1.54 million ST of uranium at $1.61 \mathrm{lb} / \mathrm{ST}$. West Rand switched back to primarily producing gold following the sharp increase in gold prices in 1974. Uranium production was resumed in January 1976. Since operations began in 1952 , the company has been the largest single producer of uranium in South Africa, although the combined output of. Vaal Reefs and Western Reefs has been greater. A large stockpile of yellowcake is in the company's possession, but the material is already committed to contracts at relatively low prices. The mine currently produces ore with a grade of about $0.61 \mathrm{lb} / \mathrm{ST}$ and the plant is producing about 50,000 ST/month. Recently, West Rand increased its reserves by purchasing an adjoining inoperable mine from Luipaardsuiei Estates.

\section{Bylvooruitzicht}

Due to the favorable uranium market conditions, the company made a decision in 1975 to increase uranium production capacity. An expanded plant for the recovery of uranium was completed in July 1977 and is now in operation. The capacity of the new plant is $110,000 \mathrm{ST} / \mathrm{month}$ up from the previous figure of $60,000 \mathrm{ST} / \mathrm{month}$ for the existing facility. The additional uranium will be derived from the treatment of previously untreated gold tailings from slime dams. Ore reserves are estimated at 3,834,000 tons of ore at a value of $0.51 \mathrm{lb} / \mathrm{sT}$ uranium.

\section{Beisa Mines}

A new uranium-gold mine will be developed south of Welkom. It will be the first large scale uranium mine developed by a South African company with gold as a byproduct. A plant with a capacity of $110,000 \mathrm{ST} / \mathrm{month}$ is planned for operation in late 1982 .

\section{President Brand Consortium}

President Brand built a uranium plant in 1971 which has a capacity of 2.4 million ST a year. Plant commissioning was delayed at the 
time due to unfavorable market conditions. The uranium plant was placed in operation in late 1976, and a recent contract will help finance further production expansions, which include a 30,000 ton/ month expansion to the uranium plant. Free State Saaiplass, Welkom, President Steyn, Free State Geduld, Freddies Consolidated and Western Holdings will also use the plant. President Brand has 4.4 million ST, Free State Saaiplass 8.5 million ST and Welkom 4.4 million ST of accumulated slimes. The uranium plant will be used to treat both current residues and reclaimed slimes. An expansion to the existing leaching plant is due to be cumpleted in late 1979.

\section{Western Deep Leve1s}

An extension to the existing $\mathrm{p} 1$ ant is being added which will proccss an additional $220,000 \mathrm{ST} / m o n t h$ to produce about $190 \mathrm{ST} \mathrm{U}_{3} \mathrm{O}_{8}$ /year. The addition will process the remaining current tailings and reclaimed slimes. Production from the expansion will start in the second half of 1981 .

\section{Stillfontein}

A new uranium plant is to be jointly built by Stillfontein and Buffelsfontein. The new facility will be sited at Stillfontein and; will have a capacity of 3.24 million tonnes/year of tailings. Operation is scheduled for 1980 . About $85 \%$ of output attributed to Stillfontein.

\section{West Driefontein}

Underground uranium production and grade has declined over the last tew years. Reduced production from undergrnund activities has been supplemented with reclamation from the surface tailings dam on which uranium slime was stored. This roquired olgnificant capital expenditures for the completion of extensions to the existing plant as well as providing facilities to pump the olimc from the storage dam to the plant.

\section{Palabora}

The uranium recovery plant began operations in 1971. Current capacity is $125 \mathrm{ST} \mathrm{U}_{3} \mathrm{O}_{8}$ /year with an expansion effective in 1979 to raise capacity to $260 \mathrm{ST}_{3} \mathrm{O}_{8}$ /year. Reserves are estimated at $28,000,0001 \mathrm{bs} . \mathrm{U}_{3} \mathrm{O}_{8}$. Production is marketed by Rio Tinto. 
East Rand Gold and Uranium Co.

The plant for treatment of slimes began trial runs in early 1978. Full production of $200 \mathrm{ST} \mathrm{U}_{3} \mathrm{O}_{8} /$ year is expected in 1979. Uranium diuranate is the end product which is shipped to NUFCOR's processing plant. Reserves are estimated at 8,000,000 1bs. $\mathrm{U}_{3} \mathrm{O}_{8}$.

Capacity, Capacity Limiting Factors, Expansion P1ans and New Facilities

The uranium production capacity of the individual mining companies will vary depending on the tonnage of ore processed and the grade of the ore. Each of the different mines have ores with different concentrations of uranium, and even at an individual mine, the grade can vary considerably. The grade of the ore processed is also influenced by the price of gold. At higher gold prices, the mines can process ores with lower concentrations of gold. Since uranium grades usually follow gold grades, higher gold prices generally mean lower production rates for uranium. In the past, this trend was more common, but with the high prices of uranium and relatively low prices of gold in the last 2-3 years, recovery of uranium has become more important. In a few mines, in fact, uranium production has made a greater contribution to profits than gold, an occurrence which will tend to stabilize uranium productions even with fluctations in gold prices.

In response to the higher uranium prices, several uranium mining companies have begun construction or announced plans for expansions or additions of new facilities. President Brand began operations in 1977 of a uranium plant that was constructed in 1971, but was not started at that time because of unfavorable price levels. In early 1977, Vaal Reefs announced the sale of uranium which included front money payments to expand its uranium production capacity. Randfontein has constructed a new gold and uranium plant and refurbished an old uranium plant. Blyvooruitzicht completed an expansion program in 1977. Harmony Gold Mine began an expansion program to its existing plant and announced plans to build a new plant. In addition, Anglo American Corp. has started a project to recover gold, sulphuric acid, and uranium from old slime dams.

Past and Present Marketing Strategy

NUFCOR now acts as the marketing agent for the individual mining companies. Contracts, however, are directly between the customer and the mining companies. The most recent contracts of this type typically involve front money to finance the construction of new production capacity. In early 1977, Vaal Reefs announced that it had sold uranium for delivery in the 1980's which included $\$ 69$ million in front money to expand production. Randfontein reportedly 
will receive over $\$ 100$ million in a similar arrangement, and President Brand announced a deal including about \$40 milion to expand its capacity. About half of all contracts in which NUFCOR has been involved are directly between the customer and the mining companies. All future contracts will be of this type.

\section{Production History}

Detailed production histories for each gold/uranium mine are not readily available. However, total historical production on a country basis is presented later under the discussion of NUFCOR which processes virtually all of the uranium for the South African mines.

\section{Projection of Future Marketing Characteristics}

The direct involvement of the mining companies in uranium sales and the arrangements for front money arc departures from the previous marketing methods. It seems apparent that the mining companies have responded to the changes in the market and have taken full advantage of their leverage in the current sellers' market. It is likely that the mining companies will continue to look for front money as long as the market will bear it. 
Facility: Nuclear Fuels Corporation of South Africa (NUFCOR)

\section{Description of Operation}

Nuclear Fuels Corporation of South Africa (NUFCOR) is a private company owned by South African gold/uranium mining companies. NUFCOR processes and markets the uranium produced as a by-product or co-product of the gold mining operations in South Africa. NUFCOR also coordinates research and development in the mining and processing of uranium, including the construction of a pilot plant for the conversion of $\mathrm{U}_{3} \mathrm{O}_{8}$ to $\mathrm{UF}_{6}$. In its processing operation, NUFCOR receives uranium from the individual mine/mills in the form of an ammonium diuranate (ADU) slurry and processes the ADU to high purity $\mathrm{U}_{3} \mathrm{O}_{8}$ through a series of steps including blending, filtering, drying . and calcining.

Capacity, Capacity Limiting Factors, Expansion Plans and New Facilities

NUFCOR's capacity is $7,800 \mathrm{ST} \mathrm{U}_{3} \mathrm{O}_{8} / \mathrm{yr}$, although recent production has been around 4,400 $\mathrm{ST} \mathrm{U}_{3 .} \mathrm{O}_{8}$ /year. Production has been significantly below capacity since the late 1950's and early 1960's, which was the only time NUFCOR operated at full capacity. With the recent price increases and resulting expansions in the extraction plants of the individual mining companies, the processing load at NUFCOR will increase each year. However, with its large capacity NUFCOR will not need to expand before the mid-1980's, if at all.

$\underline{\text { Past and Present Marketing Strategy }}$

Uranium production in South Africa began in 1952, and until the mid$1960^{\prime}$ 's dil production was sold to the Combincd Dcvelopment $\Lambda$ gency, CDA, of the United States and United Kingdom. As the CDA cut back on its purchases in the 1960's, the only other market was the small but promising commercial power reactor market. NUFCOR served as the marketing agent for all uranium produced by the mining companies. Marketing in the late 1960's and early 1970's was difficult because of the abundance of suppliers (created as a result of the CDA's demand) and the scarcity of customers. NUFCOR was able to survive this period by a combination of factors: NUFCOR was a proven, reliable supplier with a high quality product; South African uranium prices could be held low since all production came as a by-product of gold operations; and NUFCOR participated in an organization with other major suppliers that attempted to stabilize the market by allocating market shares among the various suppliers. 
Market Share Attained: 'NUFCOR

Table 22.2.4

$\left(\mathrm{ST} \mathrm{U}_{3} \mathrm{O}_{8}\right)$

Region: Domestic (S. Africa)

\begin{tabular}{|c|c|c|c|c|c|}
\hline Year & $\begin{array}{c}\text { NUFCOR } \\
\text { Déliveries } \\
\text { to S. Africa } \\
\end{array}$ & $\begin{array}{c}\text { Total } \\
\text { Deliveries } \\
\text { to S. Africa } \\
\end{array}$ & $\begin{array}{c}\text { Total } \\
\text { S. Africa } \\
\text { Requirements } \\
\end{array}$ & $\begin{array}{c}\text { Total } \\
\text { S. Africa } \\
\text { Uncommitted } \\
\end{array}$ & \begin{tabular}{l}
\multicolumn{1}{c}{ NUFCOR } \\
Market Share \\
of Committed \\
Deliveries, \%
\end{tabular} \\
\hline pre-1978 & 0 & 0 & 0 & 0 & 0.0 \\
\hline 1978 & 0 & 0 & 0 & 0 & 0.0 \\
\hline 1979 & 0 & 0 & 0 & 0 & 0.0 \\
\hline 1980 & 0 & 0 & 418 & 418 & 0.0 \\
\hline 1981 & 0 & 0 & 418 & 418 & 0.0 \\
\hline 1982 & 0 & 0 & 0 & 0 & 0.0 \\
\hline 1983 & 0 & 0 & 189 & 189 & 0.0 \\
\hline 1984 & 0 & 0 & 375 & 375 & 0.0 \\
\hline 1985 & 0 & 0 & 372 & 372 & 0.0 \\
\hline 1086 & 0 & 0 & $3 / 2$ & 372 & 0.0 \\
\hline 1987 & 0 & 0 & $37 ?$ & 372 & 0.0 \\
\hline 1988 & 0 & 0 & 372 & 372 & 0.0 \\
\hline 1989 & 0 & 0 & 372 & 372 & 0.0 \\
\hline 1990 & 0 & 0 & 878 & 878 & $\dot{0} \dot{0}$ \\
\hline
\end{tabular}


Market Share Attained: NUFCOR

Table 22.2.5 (cont.)

(ST $\mathrm{U}_{3} \mathrm{O}_{8}$ )

Region: International (Non-S. Africa, non-US)

\begin{tabular}{|c|c|c|c|c|c|}
\hline Year & $\begin{array}{c}\text { NUFCOR } \\
\text { Deliveries } \\
\end{array}$ & $\begin{array}{c}\text { Total } \\
\text { Deliveries } \\
\end{array}$ & Requirements & Uncommitted & $\begin{array}{l}\text { NUFCOR } \\
\text { Market Share } \\
\text { of Committed } \\
\text { Deliveries, \% }\end{array}$ \\
\hline pre-1978 & 12360 & 139899 & 102393 & 0 & 8.8 \\
\hline 1978 & $370 ?$ & 31155 & 20426 & 1913 & 11.9 \\
\hline 1979 & 3655 & 29946 & 24827 & 3052 & 12.1 \\
\hline 1980 & 3853 & 31563 & 26503 & 3163 & 12.1 \\
\hline 1981 & 3858 & 34098 & 28903 & 2648 & 11.3 \\
\hline 1982 & 4659. & 34918 & 30337 & 2834 & 13.3 \\
\hline 1983 & 4974 & 36223 & 36792 & 4944 & 13.7 \\
\hline 1984 & 4750 & 38585 & 40628 & 8816 & 12.3 \\
\hline 1985 & 4183 & 37023 & 46585 & 13338 & 11.3 \\
\hline 1986 & 3734 & 33425 & 52871 & 21103 & 11.2 \\
\hline 1987. & 3539 & 32237 & 54842 & 23535 & 11.0 \\
\hline 1988 & 2249 & 32645 & 64498 & 33647 & 6.9 \\
\hline 1989 & 2249 & 30317 & 65703 & 33907 & 7.4 \\
\hline 1990 & 2249 & 31172 & 76479 & 42697 & 7.2 \\
\hline
\end{tabular}


Recent Production History

$\begin{array}{ll}\text { Year } & \text { MTU } \\ 1972 & 3070 \\ 1973 & 2617 \\ 1974 & 2600 \\ 1975 & 2377 \\ 1976 & 2707 \\ 1911 & 3396\end{array}$

Projection of Future Marketing Characteristics

NUFCOR has committed most of its output through the mid-1980's, so 1ts marketing efforts will be limited in the near future. Recently NUFCOR has assisted some of the individual mining companies in their negotiations involving front money payments to finance new construction (see the section entitled "South African Gold/Uranium Mining Companies"). Marketing in the late 1980's may be linked to UCOR's marketing efforts (see the section entitled "Uranium Enrichment Corporation of South Africa"). 
Facility: Uranium Enrichment Corporation of South Africa (UCOR)

\section{Description of Operation}

The Uranium Enrichment Corporation of South Africa (UCOR) is a government corporation responsible for the research and development of uranium enrichment technology. UCOR has completed the construction of a pilot enrichment plant at Val1ndaba to demonstrate its technique on an industrial scale. The expertence gained in the construction and operation of the pllot plant w1ll provide technical foundation for the design and construction of a commercial size facility. The pilot facility is being converted into a small commercial operation. The UCOR enrichment process is an aerodynamic type, similar to the jet nozzle technique and uses $\mathrm{UF}_{6}$ in hydrogen as the process fluid.

\section{Capacity, Capacity Limiting Factors, Expansion Plans and New Facilities}

The rated capacity of the UCOR pilot plant is $6 \mathrm{MTSWU} / \mathrm{yr}$. The next stage in South Africa's development program is to construct a commercial scale facility. It is generally felt that the smallest economical size of an enrichment plant using the UCOR process would be 5,000 MTSWU/yr. However, given the clear world oversupply of SWU, considerable delay can be expected. Even the announced smaller plant ( $250 \mathrm{MTSWU} /$ year for S. African use) may be questionable.

\section{Past and Present Marketing Strategy}

Although they have not begun organized marketing efforts, UCOR representatives have stated that they are prepared to discuss supply arrangements with interested utilities. However, at this time, it is not likely that UCOR has a formal contract document or would be in a position to make a firm supply commltment.

\section{Projection of Future Marketing Characteristics}

UCOR's future marketing strategy is very simple; if someone wishes to purchase South African uranium, he must purchase it in the enriched form. It is believed that all new uranium supply contracts have a clause stipulating that if South African enrichment capability does exist, then uranfum to be delivered after 1986 will be delivered as enriched $\mathrm{UF}_{6}$. 
Vested Interest in Current Fuel Cycles and Reactor Technologies

South Africa has a vested interest in the enriched uranium fuel cycle (and therefore in light water reactor technology) because of the commitment by the South African government to develop commercial uranium enrichment capacity. South Africa is the only country in the world that is constructing enrichment capacity primarily for export, rather than assurance of supply for domestic reactors (although both Canada and Australia have conducted feasibility studies for developing enrichment capacity for the export marlcet). South Africa's illvestment in ics pilot enrichment plant is significant for a country its size and the investment in a commercial size plant will be far greater. A major shift in preference tor tuel cycles such as the natural uranium fuel cycle in the Candu-type reactor or the natural uranium plutonium fuel cycle of the fast breeder reactor (such a shift could occur concurrently with the construction schedule of South Africa's commercial enrichment plant), would reduce the export market (since all light water reactors surrently planned already havo onrichment services contracts), and could have a very adverse effect on the government's financial position. Thus, South Africa has a strong vested interest in the continued acceptance and growth of reactor technologies that are based on enriched uranium fuel cycles.

\section{Current Trends in Nuclear Development Programs}

There are two contrasting trends in the South African government's nuclear development programs. In its power reactor program, the government (through the state-owned Electric Supply Commission, or ESCOM) has chosen a conservative route, purchasing proven reactor technology from an established foreign supplier. On the other hand, in its fuel cycle development programs, the government (through the Atomic Energy Board, AEB) has exhibited a very independent nature, embarking on an aggresslve enrichment development program without any significant outside assistance. In fact, the program has been viewed with great skepticism outside of South Africa, with many experts questioning the technical and economic feasibility of the projer.t. Criticism of the projcct, however, seems only to have increased the resolve of the South Afriran government to prove it can be successful. It appears that this contrast will continue into the foreseeable future. ESCOM, when it adds new plants to its system, will look to experienced foreign suppliers, while another arm of the government, the AEB, will continue on its path to commercialize a novel enrichment ter.hnique. 
Table 22.3.1

Not Available

KEY TECHNICAL EDUCATIONAL RESOURCES

$\underline{\text { Table 22.3.2 }}$

\footnotetext{
Institution

University of Cape Town

University of Pretoria

University of Stellenbosch

University of the Witwaterstrand

Potchefstroom University
}

Location

Rondebosch

Hillcrest, Pretoria

stellenbosch

Johannesburg

Potchefstroom 


\section{KEY GOVERNMENTAL NUCLEAR RESEARCH ORGANIZATIONS}

Table 22.3.3

Name

National Nuclear Research Center

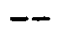

$-$

Southern Universities Institute
Location

Pelindaba, near Pretoria

Vanindaba

Pelindaba

Faure, near

Cape Town
Main Activities

minerals prospecting and mining; mineral investigating; reactor and reactor fuel

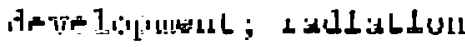
all liedlih physics; rad1oicotope production and application; basic and applied production; peaceful application of nuclear explosions; reac:tor safety and operation.

pilot-scale uranium enrichment

uranium metal and compoinds for fuel.

basic nuclear research 
KEY PRIVATE NUCLEAR RESEARCH ORGANIZATIONS

Table 22.3.4

$\underline{\text { Name }}$

Owner

Location

Main Activities. 
RESEARCH AND TEST REACTORS

List of Reactors

Table

22.3 .5
Facility

Name.

SAFARI-1

Pelinduna Zero

\section{Location}

Pelindaba

Pelindaba

\section{Onner}

NNRC.

S. African
Atomic Energy
Bcard

S. African
Atomic Energy

Bcard

\section{Constructor}

Allis Chalmers

S. African Atomic Energy Board

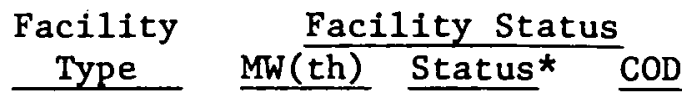

ORR-tank $20 \quad 0 \quad 1965$

$90 \% U^{235}$

Critical 0

$0 \quad 1967$

* 0-Operational; U-Under Construction; P-P-anned; S-Shutdown 
INDIGENOUS CAPABILITY TO DESIGN AND SUPPLY RESEARCH AND TEST REACTORS AND FUEL SERVICES Summary of Reactor Orders by Vendor and Country

Table 22.3.6

\begin{tabular}{lll} 
Vendor Country & $\begin{array}{l}\text { Facility } \\
\text { Name }\end{array}$ & $\begin{array}{c}\text { Facility } \\
\text { Type }\end{array}$ \\
\hline
\end{tabular}

Not App1icable

* O-Operational; U-Under Construction; P-Planned; S-Shutdown 
SUMMARY OF FUEL SERVICES FOR RESEARCE AND TEST RESCTCRS

Tajle 22.3.7

Facility

Name

Location

Facility

Type

Capacity Status

Status* Year Shareholdings

None kr.own, however, the SAAEB did complete

$\exists$ pilot plant to produce nuclear-grade uranium metal and compounds suitable for nuclear fuels in 1961.

It has been stated that the pilot enrichment plant can produce fuel suitcble for -he SAFARI-1 resear 2 h reactor.

* O-Operational; U-Under Construction; P-Planned; S-Shutdown 


\section{ECONOMIC DATA PROFILE}

Tab1e 22:4.1

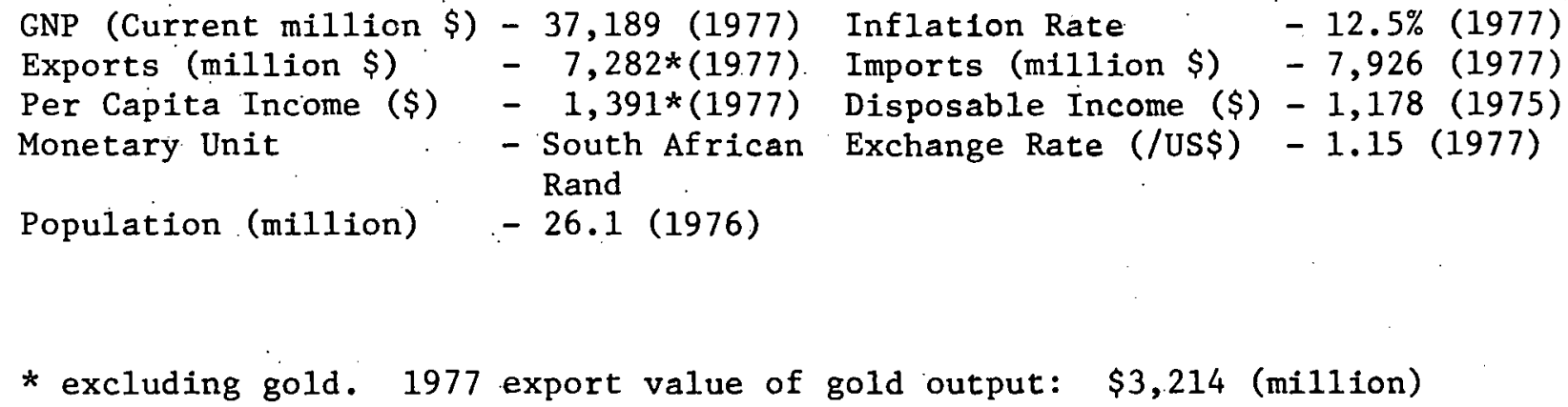

South African Atomic Energy Board (FY74) - \$10.9 m1111on 
Table 22.4.3

\begin{tabular}{|c|c|}
\hline $\begin{array}{l}\text { Industry } \\
\text { Untversity or } \\
\text { Laboratory } \\
\end{array}$ & $\begin{array}{l}\text { Program } \\
\text { Area } \\
\end{array}$ \\
\hline $\begin{array}{l}\text { University of } \\
\text { Stellenbosch }\end{array}$ & $\begin{array}{l}\text { radioisotopes } \\
\text { in plant biology, } \\
\text { neutron meters } \\
\text { for soil mnisture }\end{array}$ \\
\hline $\begin{array}{l}\text { University of } \\
\text { Pretnria... }\end{array}$ & - \\
\hline $\begin{array}{l}\text { Unlversity fienrral. } \\
\text { Hospital }\end{array}$ & $\begin{array}{l}\text { irradiation of } \\
\text { circulating blood }\end{array}$ \\
\hline $\begin{array}{l}\text { University of } \\
\text { Caperown }\end{array}$ & nuclear medicine \\
\hline $\begin{array}{l}\text { South Africa } \\
\text { Institute for } \\
\text { Medical Research }\end{array}$ & $\begin{array}{l}\text { nuclear physics } \\
\text { training }\end{array}$ \\
\hline $\begin{array}{l}\text { Veterinary Station } \\
\text { and School }\end{array}$ & $\begin{array}{l}\text { metabolic } \\
\text { disease }\end{array}$ \\
\hline $\begin{array}{l}\text { Univeroity of } \\
\text { Witwatcrgrand }\end{array}$ & basle research \\
\hline
\end{tabular}

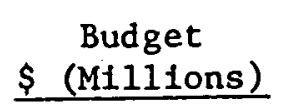

Key

Personne1

radioisotopes

in plant biology,

neutron meters

for soil. moisture

irradiation of

cilating blood

nuclear physics

training

metabolic

basle research
\$ (Millions)
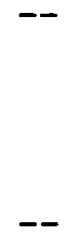

$-\infty$

$-$

22.4.4 ROLE OF PRIVATE INDUSTRY IN NUCLEAR ENERGY R\&D

Not Applicable 
ECONOMIC PROFILE OF REACTOR VENDORS AND FUEL CYCLE FACILITIES

Table 22.4.5

$\underline{\text { Name }}$

Share Capital

Assets

$\underline{\text { Sales }}$

Not Applicable

22.4 .6

MODE OF FINANCING OF NUCLEAR POWER PLANTS

The Koeberg reactors are supplied by Framatome. The billion-dollar contract went $40 \%$ to Framatome, $40 \%$ to Alsthom and $20 \%$ to Spie-Batignolles. Financing is supervised by the French bank Credit Lyonnais and guaranteed by CIE Francaise d' Assurance pour le Commerce Exterieur (COFACE), a government agency. 
22.5 GOVERNMENT COMMITMENT AND ROLE IN NUCLEAR POWER DEVELOPMENT

\subsubsection{ENERGY POLICY - BASIC LEGISLATION}

1. South African Atomic Energy Board (SAAEB) estab1ished in 1949.

2. Indigenous research and development nuclear program begin in 1957.

3. Act No. 90 of 1967 imposes severe sanctions on anyone guilty of puls 1ishing material relating to the prospccting, production, and pricing of uranium.

4. I'hird 5-year SAAEB program initiated in 1969.

5. Government passed a law stipulating that any application for a uranium enrichment patent by any company or organization other than South African Atomic Energy Board will be illegal.

22.5.2 GOVERTMENTAL STRUCTURE FUK NULLLAK ENERGY YOLICY AND R\&D

Council for Scienlific and Industrial Researrh - nverall national program of scientific research.

South African Atomic Energy Board:

- Conducts the South African Atomic Energy Program

- Assisted by 10 technical and advisory cumittees

- Activities conducted under 5-year plan 
South African Atomic Energy Board is the major force in Implementing nuclear energy policy and R\&D.

\subsubsection{NUCLEAR ENERGY POLICY AND OBJECTIVES}

The specific nuclear energy policy is unknown, however, it can be inferred that nuclear power is to be used to further South Africa's policy of reducing dependence on forelgn energy sources (chlefly, oil). Towards that end, objectives of the program are:

- minerals prospecting and mining

- extraction and sale of uranium

- development of uranium enriching capability

- reactor and reactor fuel development

- radiation and health physics

- radioisotope application and production

\subsubsection{NUCLEAR ENERGY R\&D - STATUS AND OUTLOOK}

The most pertinent area of South African Nuclear Energy R\&D is enrichment. In this area, the pilot plant at Vanindaba is operational, and in early 1978, it was announced that a commerclal factlity (200-300 MTSWU/year) would be construrted. Th1s facility would be directed towards indigenous needs; particlpation in the world enrichment market is possible at a later date. 
To further the fundamental objective of lessening dependence on foreign energy sources (or control), priorities are believed to be:

1. Enrichment

2. Uranium mining and milling technology

22.5.7 ROLE OF GOVERNMENT IN NUCLEAR FACILITIES CONSTRUCTION AND OPERATION

ESCOM (Electricity Supply Commission, a government agency) planned, negotiated for, and will opeiale llie Lwo cummerclal nuclear power plants - Koeberg I \& II. The government w1ll provide regulatory requirements. 
22.6 NON-NUCLEAR ENERGY FACILITIES AND FUEL SUPPLY

SOITTH AFRTSA:-39 


\section{ENERGY GENERATION FACILITIES IN EXISTENCE AND FIRMLY PLANNED PRODUCING 100 MWe (net)}

Table 22.6.1 (Continued)

\begin{tabular}{|c|c|c|c|}
\hline $\begin{array}{l}\text { Facizity } \\
\text { Nane } \\
\end{array}$ & Location & $\begin{array}{l}\text { Jtility/ } \\
\text { Jwner }\end{array}$ & Vendor \\
\hline West Bank $1+2$ & Eastern Cape & Escom & \\
\hline Salt River $1+2$ & Western Cape & Es com & \\
\hline Hex River & Western Cape & Escom & \\
\hline Port Rex & Eastern Cape & Iscom & \\
\hline Acacia & Western Cape & $\Xi \mathrm{scom}$ & \\
\hline $\begin{array}{l}\text { Hendrik } \\
\text { Verwoerd }\end{array}$ & Orange River & Escom & \\
\hline Matla & Transvaal toFs & Escom & \\
\hline Duvha & Transvaal +OFS & Escom & . \\
\hline Vanderkloof & $\begin{array}{l}\text { Orange River } \\
\text { (PK le Roux Dam) }\end{array}$ & Escom & \\
\hline Drakensberg & Natal & Escom & \\
\hline Elandsb erg & SW Cape & Escom & 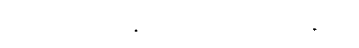 \\
\hline
\end{tabular}

\begin{tabular}{|c|c|c|c|}
\hline $\begin{array}{c}\text { Fac1lity } \\
\text { Type } \\
\text { (Fuel Type) } \\
\end{array}$ & $\begin{array}{l}\text { Capacity } \\
\text { (NWe net) } \\
\end{array}$ & Status* & COD \\
\hline Coal & 101 & 0 & \\
\hline Coal & 285 & 0 & $\cdot$ \\
\hline Coal & 114 & 0 & \\
\hline $\begin{array}{l}\text { Gas Turbine } \\
\text { (Oi1) }\end{array}$ & 171 & 0 & 1976 \\
\hline $\begin{array}{l}\text { Gas Turbine } \\
\text { (OiI) }\end{array}$ & 171 & 0 & 1976 \\
\hline Hydro & 320 & 0 & $\begin{array}{l}1976 \\
\text { (Sets 1+2) }\end{array}$ \\
\hline Coa1 & 3,600 & $\mathrm{U}$ & $\begin{array}{l}1979 \\
\text { onwards }\end{array}$ \\
\hline Coal & 3,600 & $\mathrm{U}$ & $\begin{array}{l}1979 \\
\text { onwards }\end{array}$ \\
\hline Hydro & 220 & 0 & 1977. \\
\hline Hydro (PS) & 1,000 & $\mathrm{U}$ & $1980-81$ \\
\hline Hydro (PS) & 1,000 & $\mathrm{P}$ & Late $1980 \mathrm{~s}$ \\
\hline
\end{tabular}

* 0-Operational; D-Under Construstion; P-Planned; S-Shutdown 
SUMMARY OF ENERGY GENERATION FACILITIES IN EXISTENCE AND PLANNED

Table 22.6 .2

\begin{tabular}{lc} 
Year & Capacity - MWe (net) \\
\hline 1975 & 14,154 \\
1980 & $2 /, 17 / 4$ \\
1905 & 27,318 \\
1990 & \\
1995 & \\
2000 &
\end{tabular}




\section{LISTING OF FIJEL SUPPLY FACILITIES IN EXISTENCE AND FIRMLY PLANNED}

Table 22:6.3

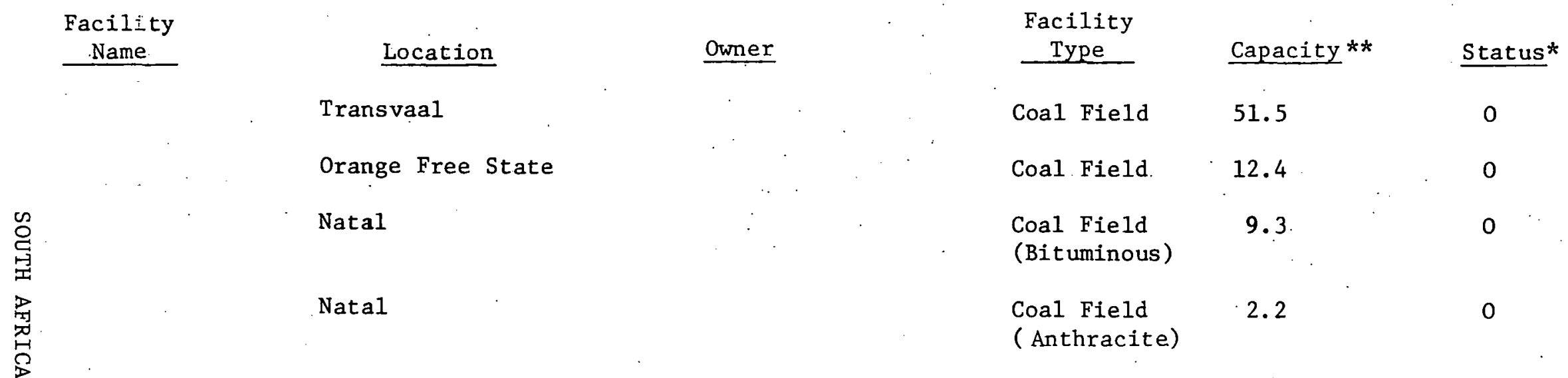

* O-Operational; U-Under Construction; P-P1anned; S-Shutdown ** Coal-Millicn tonnes/year 
Table 22.6.4

$\underline{\text { RESOURCE }}$

COAL (million tonnes)

Indigenous Supply

Imports

Exports

\section{CRUDE OIL (million tonnes) \\ Indigenous Supply \\ Importa \\ Exports}

SHALE OIL (million tonnes)

Indigenous Supply

Imports

Exports

NATURAL GAS (cubic kilometers)

Indigenous Supply

Imports

Exports

URANIUM (kilutimmes U.jOgi)

Indigenous Supply

Imports

Exports $\underline{1985}$

2000

119

233

44.9

145.2

0

25.7

42.1

0

0 .

0

0

3.9

3. 7

-

14.7

0

15.4

14.4

13.0 
SECTION 23

SOUTH KOREA 
23.1 PROJECTED INDIGENOUS ENERGY RESOURCES, DEMANDS AND RELATED INFORMATION

\section{INDIGENOUS RESOURCES}

South Korea has significant resources of coal and these are predominantly high ranking. Total resources are estimated at 1,434 million tonnes of which 327 million tonnes are economically recoverable (ref. 1.2). The latter figure has been reduced from that of 544 million tonnes stated in reference 1.1 . The total resource figure is given as $1,450 \mathrm{million}$ tonnes in reference 1.25 and can thus be considered firm.

No resources of crude. oil, shale oil or natural gas have been reported.

A small amount of hydro-power is available. Generation (as at 1975) was 1.7 TWh with a further 2.3 TWh under construction or planned. The total theoretical capacity is estimated at approximately twice this amount, i.e. $7.7 \mathrm{TWh}$.

South Korea has only very small indigenous uranium resources.

\section{ENERGY SUPPLY}

Production of hard coal stood at 16.785 million tonnes (Paper XXVI, ref. 1.23). Reference 1.5 gives a value of 17.59 million tonnes and reference $1.2,15.2$ million tonnes for 1974 . Reference 1.5 notes a very small amount of imports, one-third from the United States.

Al1 crude oil is imported. The quantity in 1975 was put at 15.972 million tonnes (ref. 1.5). Reference 1.23, Paper XXVI gives imports of crude oil as 14.14 million tonnes in 1973.

No nuclear power was used in 1975 .

\section{PATTERNS OF ENERGY. USE}

The figures given in Table 23.1 .3 were supplied by private communication. 


\section{FORECASTS OF ENERGY SUPPLY AND DEMAND}

The total primary energy demand in South Korea increased at an average annual rate of $11.2 \%$ between 1965 and 1974 (refs. 1.5 and 1.44) while economic growth average 10.5\% (ref. 1.43). In the same period, electricity demand increased by an average $19.8 \%$ per year. The energy and electricity demand forecasts presented in Table 23.1.4 indicate average rates of growth of demand from 1975 to 2000 ranging from $4.5 \%$ to $10.0 \%$ for primary energy and from $3.1 \%$ to $6.7 \%$ for electricity.

A forecast of energy demand presented to the United Nations Economic and Social Commission for Asia and the Pacific (ESCAP) in 1974 projected an annual rate of demand growth of $10.5 \%$ from 1973 to 1981 (ref. 1.23), but the continuing escalation of energy prices since that time is likely to have caused these projections to be revised downwards. Information provided at the Second Pacific Basin Conference indicated a projected GNF growth race trending from $10.2 \%$ in 1978 , to $9.0 \%$ by 2000 . Coupled with that, peak electrical demand growth rates ranged from $15 \%$ in 1980 , to $10 \%$ in 2000 .

The energy demand breakdown shown in Table 23.1 .5 shows the effects of the trends that were indicated in reference 1.23 continuing through to 2000. Oil consumption is expected to increase both in absolute and relative terms as the only means of meeting the growth in energy demand in this rapidly developing country. Longer term plans to reduce the rate of growth of oil demand include the exploitation of tidal power which it is expected will contribute 6 TWh in 2000. Nuclear power capacity is also expected to provide a significant proportion of future energy requirements and installed capacity should reach 4469 MW by 1985 . In 1992, the nuclear electricity demand should be approximately 40 TWh. From 1993 to 2000 , nuclear capacity is expected to increase by 1200 MWe every year. As ambitious as this may be, Korea has announced a plan to have 44 nuclear. plants operating by 2000 , approximately 51,000 MWe. Under this plan, 12 reactors would be operational by 1989 and the installation rate would grow to four 1200 MWe reactors per year after 1996. 


\section{INDIGENOUS ENERGY RESOURCES}

Table 23.1.1

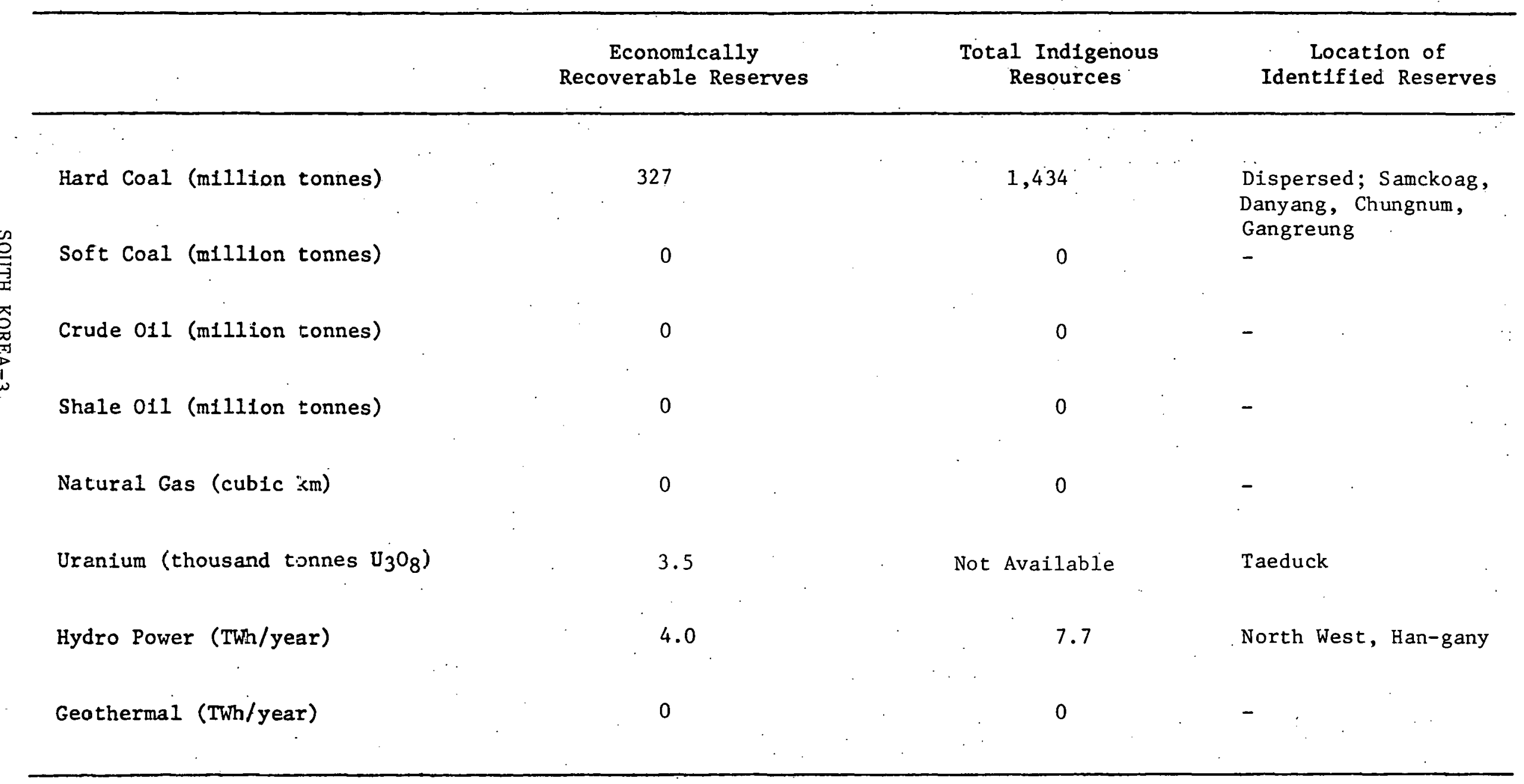




\section{ENEKGY SUPPLY 1975}

Table 23.1.2

\begin{tabular}{|c|c|c|c|c|c|}
\hline \multirow[t]{2}{*}{ Resource } & \multirow{2}{*}{$\begin{array}{l}\text { Indigenous } \\
\text { Supply }\end{array}$} & \multicolumn{2}{|c|}{ Imports } & \multicolumn{2}{|c|}{ Exports } \\
\hline & & Total & $\%$ from US & Total & $\%$ to US \\
\hline & & & , & & \\
\hline Hard Coal (million tonnes) & 16.785 & 0.774 & 33 & 0 & 0 \\
\hline Soft Coal (milion tonnes) & 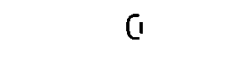 & 0 & 》) & 0 & 0 \\
\hline Crude $0: 11$ (million tornes) & G & 15.972 & 1) & 0 & 0 \\
\hline Shale oil (millon tonnes) & c. & 0 & 1) & 0 & 0 \\
\hline Natural Gas icubic km) & C & 0 & D) & 0 & 0 \\
\hline Uranium (thousand tonnes $\mathrm{U}_{3} \mathrm{O}_{8}$ ) & C & 0 & 10 & 0 & 0 \\
\hline Electric1ty (TWh) & $20 . \varepsilon$ & 0 & 0 & 0 & 0 \\
\hline & & & 1 & & \\
\hline
\end{tabular}




\section{PATTERNS OF ENERGY SOURCES AND USES 1975}

\section{Table 23.1.3}

\begin{tabular}{|c|c|c|c|c|c|}
\hline \multirow{2}{*}{ Resource } & \multicolumn{4}{|c|}{ Consuming Sector } & \multirow[b]{2}{*}{ Total } \\
\hline & $\begin{array}{l}\text { Household and } \\
\text { Commercial }\end{array}$ & Industrial & Transportation & $\begin{array}{l}\text { Electrical } \\
\text { Generation }\end{array}$ & \\
\hline Coal (million tonnes) & 13.911 & 1.653 & 0.042 & 1.349 & 16.96 \\
\hline Petroleum (million tonnes) & 2.345 & 4.543 & 3.855 & 3.029 & 13.77 \\
\hline Natural Gas (cublc $\mathrm{km}$ ) & 0 & 0 & 0 & & \\
\hline Nuclear Power (TWh) & 0 & 0 & 0 & 0 & 0 \\
\hline Hydro Power (TWh) & 0 & 0 & 0 & 1.683 & 1.683 \\
\hline Geothermal Power (TWh) & 0 & 0 & 0 & 0 & 0 \\
\hline $\begin{array}{l}\text { Utility Electricity } \\
\text { Distributed (TWh) }\end{array}$ & 3.027 & 13.586 & 0 & 0.017 & 16.63 \\
\hline
\end{tabular}


FORECASTS OF ANNUAL ENERCY DEMAND AND ELECTRICITY DEMAND

Table 23.1.4

\begin{tabular}{|c|c|c|c|c|c|c|}
\hline \multirow[t]{2}{*}{ Year } & \multicolumn{2}{|c|}{$\begin{array}{l}\text { Low Ezonomic Growth } \\
5.0 \%\end{array}$} & \multicolumn{2}{|c|}{$\begin{array}{c}\text { Medium Economic Growth } \\
8.0 \% \\
\end{array}$} & \multicolumn{2}{|c|}{$\begin{array}{c}\text { High Economic Growth } \\
11.0 \% \\
\end{array}$} \\
\hline & $\begin{array}{c}\text { Total Primary } \\
\text { Energy } \\
\left(10^{12} \text { Btu }\right)\end{array}$ & $\begin{array}{l}\text { Electricity } \\
\text { (IWh) }\end{array}$ & $\begin{array}{c}\text { Total Primary } \\
\text { Energy } \\
\left(10^{12} \mathrm{Btu}\right)\end{array}$ & $\begin{array}{c}\text { Electricity } \\
\text { (TWh) }\end{array}$ & $\begin{array}{c}\text { Total Primary } \\
\text { Energy } \\
\left(10^{12} \text { Btu }\right)\end{array}$ & $\begin{array}{c}\text { Electriclty } \\
(\mathrm{TWh})\end{array}$ \\
\hline 1975 & 1,013 & 20.8 & 1,013 & 20.8 & 1,013 & 20.8 \\
\hline 1985 & 1,525 & 28.2 & 2,006 & 33.6 & 2,926 & 39.9 \\
\hline 2000 & 3,076 & $\angle 4.5$ & 5,639 & 69.1 & 10,896 & 105.9 \\
\hline
\end{tabular}


CONSUMPTION OF ENERGY RESOURCES

Table 23.1 .5

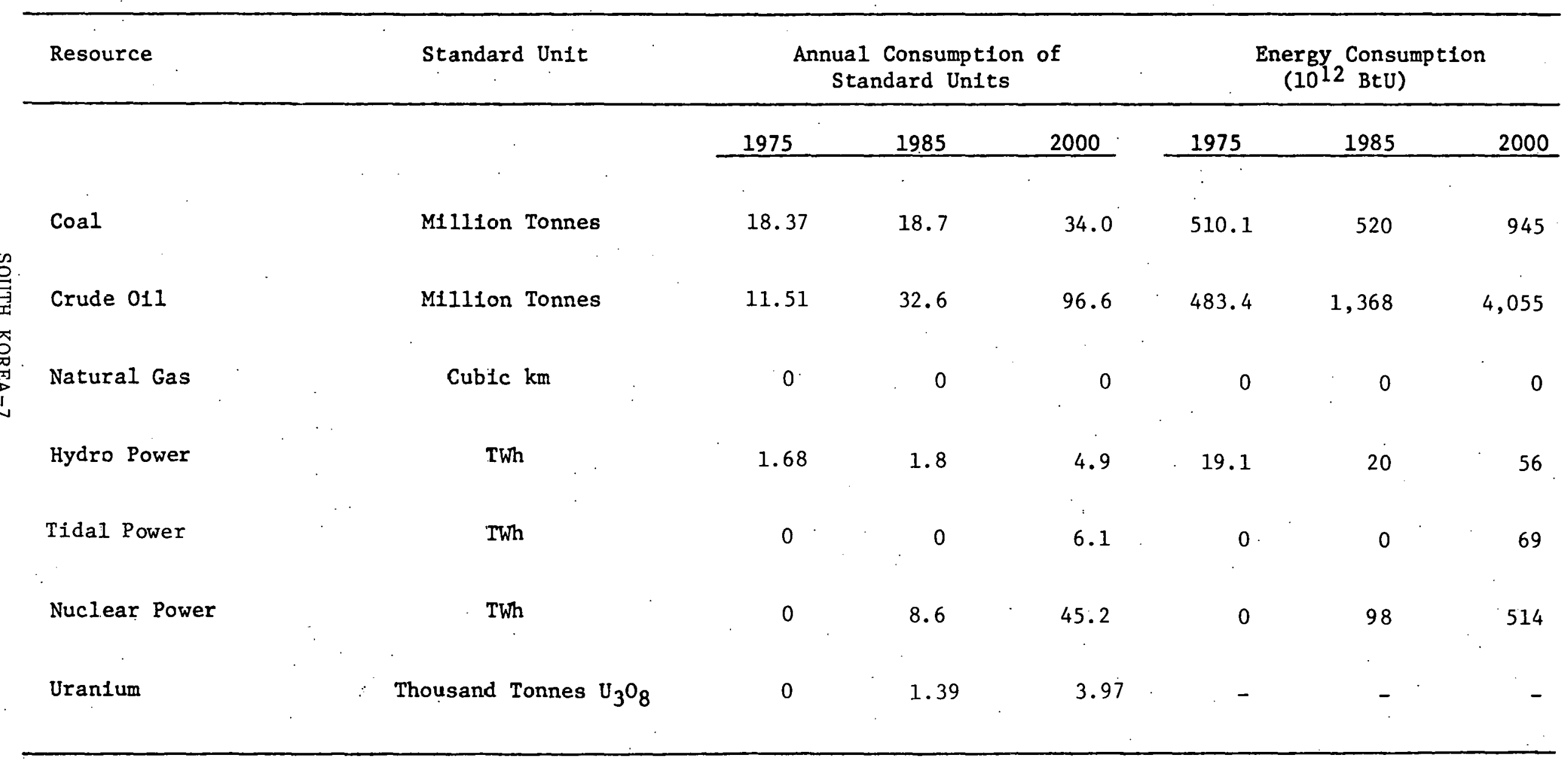


23.2 NUCLEAR HISTORY, CAPABILITY, COMMITMENT AND TRENDS

COMMERCIAL NUCLEAR POWER PLANTS

Table 23.2.1

\begin{tabular}{|c|c|c|c|c|c|c|}
\hline $\begin{array}{l}\text { Fasility } \\
\text { Name }\end{array}$ & Ueiilcy & $\begin{array}{l}\text { acility } \\
\text { 'lype }\end{array}$ & Ventinr & $\begin{array}{l}\text { liaparity } \\
\text { (MWe net) }\end{array}$ & Statuo* & COD \\
\hline Kori-1 & Korea Elec. Co. & PWR & Westinghouse & 564 & 0 & Apr 1978 \\
\hline Kori-2 & Korea Elec. Co. & PWR & Westinghouse & 605 & U & Der 1983 \\
\hline Wolsung-1 & Korea Elec. Co. & Candu & AECL & 600 & $\mathrm{U}$ & June 1982 \\
\hline Kori-3 & Korea Elec. Co. & PWR & Westinghouse & 900 & U & Sep 1984 \\
\hline Kori-4 & Korea Elec. Co. & PWR & Westinghouse & 900 & $\mathrm{U}$ & Sep 1985 \\
\hline Kori-5 & Korea Elec. Co. & PWR & - & 900 & $\mathrm{P}$ & 1986 \\
\hline Kori-6 & Kurea Elec. Co. & PWR & - & 900 & $P$ & 1986 \\
\hline
\end{tabular}

* 0-Operational; U-Under Construction; P-Planned 
Iable 23.2.2

\begin{tabular}{|c|c|c|c|c|c|c|c|c|c|}
\hline & & & & & & & & Firm + & $\mathrm{NAC}$ \\
\hline Year & PWR & BWR & Magnox & AGR & CANDU & Other & FBR & $\begin{array}{l}\text { Cumulative } \\
\text { Total }\end{array}$ & $\begin{array}{l}\text { Cumulative } \\
\text { Projection }\end{array}$ \\
\hline
\end{tabular}

$\begin{array}{rrr}\text { pre-1978 } & & \\ 1978 & 564 & \\ 1979 & & \\ 1980 & \\ 1981 & & \\ 1982 & & \\ 1983 & 605 & \\ 1984 & 900 & \\ 1985 & 900 & \\ 1986 & 1800 & \\ 1987 & 450 & 450 \\ 1988 & & \\ 1989 & 450 & 450 \\ 1990 & 450 & 450 \\ 1991 & 450 & 450 \\ 1992 & 450 & 450 \\ 1993 & 600 & 600 \\ 1994 & 600 & 600 \\ 1995 & 600 & 600 \\ 1996 & 600 & 600 \\ 1997 & 600 & 600 \\ 1998 & 600 & 600 \\ 1999 & 600 & 600 \\ 2000 & 600 & 600\end{array}$

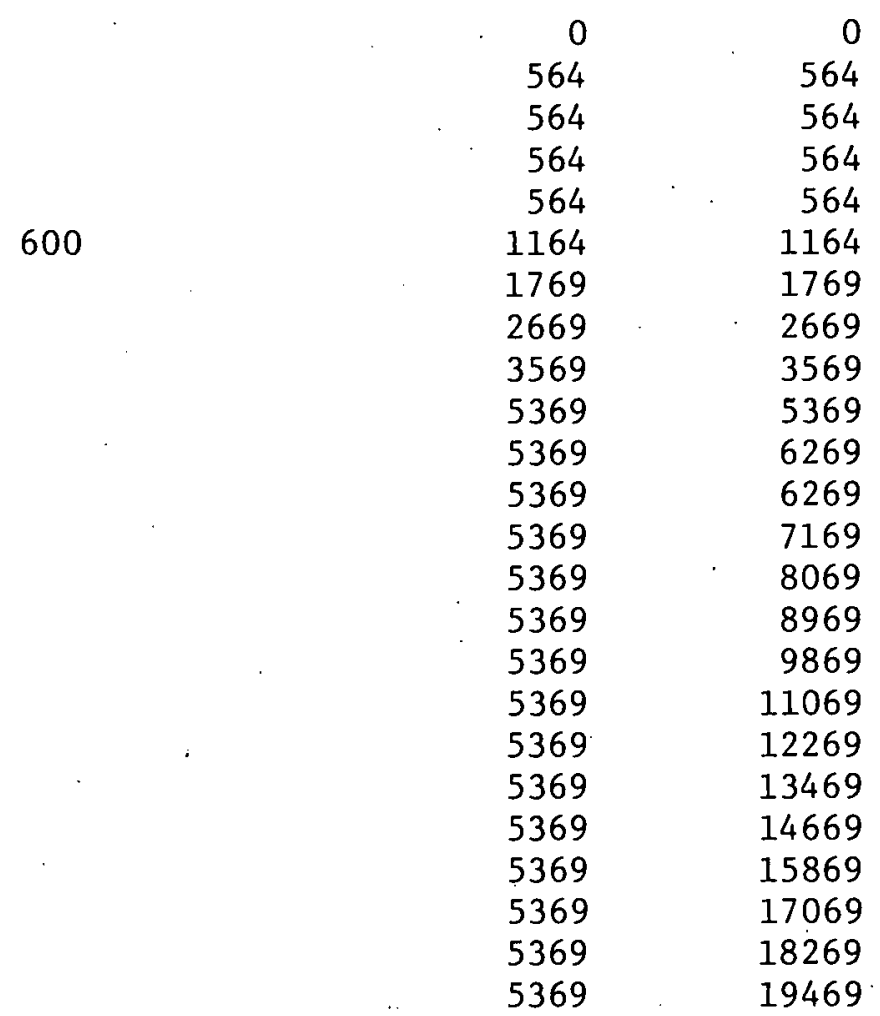




\section{NUCLEAR REACTOR VENDORS}

\section{Overview}

There are no reactor vendors in South Korea. The government has announced its intention to establish an architect engineering corporation (through the government's nuclear research branch, the Korea Atomic Energy Research Institute, KAERI and the Korea Nuclear Engineering Services, Inc., KNE) in a joint venture with experienced overseas firms to develop domestic capability for reactor construction. Plans are to develop indigenous capability to the point that $55 \%$ of the equipment and site materials could be supplied domestically by 1981 and over $90 \%$ by 1990 . Towards this end, Hyundai, a major Korean industrial group, signed an agreement with Westinghouse in late 1978 to establish a joint venture company in Korea far the manufacture of reactor systems and turbine generator components. The objective is to develop the ability to design and manufarture complctc reaclul syscems in Korea.

\section{NUCLEAR FUEL CYCLE FACILITIES}

\section{Overview}

There are no commercial fuel fabrication facilities in Korea, but the government has plans to construct a facility for nuclear fuel research and development. The project will be a part of the Korea Atomic Energy Research Institute (KAERI). Korea's first processing facility for nuclear fuel will probably be a fabrication plant. The government has expressed interest in having fabriration capability, bul recognizes that a joint venture with another country (such as Taiwan) would be necessary to justify an economical1y sized plant. Kuitu urdered a reprocessing plant from France in 1975, but political pressure caused the two countries lo terminate the agreement. A pllot uranium mill began operation in 1978 with a capacity of about $10 \mathrm{MTU} /$ year. Thc facility is located at Taeduck, south of Seoul. 
Vested Interests in Current Reactor Technologies and Fuel Cycles

Korea has little vested interest in any particular fuel cycle or reactor technology. Korea Electric Company (KECO), the state-owned power company, has two Westinghouse PWR's and one CANDU and have ordered two additional units from Westinghouse.

Current Trends in Nuclear Development Programs

Korea has a rapidly expanding economy and a concurrent growth in power requirements (the current growth rate and forecasted near-term growth rate for electricity is $15 \%$ /year). Korea plans to meet the increasing demand for electricity with nuclear power, with plans for almost one plant per year from 1982 on. As its commitment to nuclear power increases, the Korean government plans to increase the manufacturing capabilities of domestic industries to provide a greater contribution to the plant construction and fuel processing. 


\subsection{NUCLEAR TECHNOLOGY CAPABILITY AND RESOURCES}

PROFESSIONAL LABOR FORCE PROFILE

Table 23.3.1

Available information presents the following data for 1973:

369,1933 jcienlisls and Engineers

6,065 Scientists and Engineers

engaged in $R \& D$ 


\section{KEY TECHNICAL EDUCATIONAL RESOURCES}

Table 23.3.2

\section{Institution}

Pusan National University

Choong-nam National University

Dankook University

Dong-A University

Kon-Kuk University

Korea University

Gyeong Bug National University

Kyung Hee University

Hanyang University

Hongik University

Inha University

Jeonbug National University

Jeon-nam National University

Joseon University

Shung-ang University

Seoul National University

Sungjeon University

Ulsan Institute of Technology

Yeung nam University

Yonsei University
Location

Busan

Chungcheng Namdo

Seoul

Busan

Seoul

Seoul

Gyeongsang Bugdo

Seoul

Seoul

Seou1

Inchon

Jeolla Budgo

Jeolla Namdo

Jeolla Namdo

Seoul

Seoul

Seou1

Gyeongsang Namdo

Syongsangbuk-do Taegu

Seou1 
KEY GOVERNMENTAL NUCLEAR RESEARCH ORGANIZATIONS

Table 23.3.3

Name

Atomic Energy Bureau

Ministry of Science

and Technology

Atomic Energy Commission
Location

Seoul

Seoul
Main Activities 
KEY PRIVATE NUCLEAR RESEARCH ORGANIZATIONS

Table 23.3.4

Name

Dwner

Location

Main Activities

NOT APPLICABLE

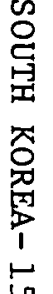


RES IARCH AND TEST REACTORS

List of Reactors

Table 23.3 .5

\section{Factlity}

Name

TRIGA-II-Seou.1

Location

Owner

Seoul

Atomic Energy Authority
Constructor

General Dyramics Corporation
Facility Type MW(th) Status* COD

$\mathrm{U}-\mathrm{Zr}$ hydride

* O-Operational; U-Urder Construction; P-Planney; S-Shutdown 
INDIGENOUS CAPABILITY TO DESIGN AND SUPPLY RESEARCH AND TEST REACTORS AND FUEL SERVICES Summary of Reactor Orders by Vendor and Country

Table 23.3.6

Vendor Country $\quad \begin{aligned} & \text { Facility } \\ & \text { Name }\end{aligned}$

Facility Type
Scope of Services 
SUMMARY OZ FUEL SERVICES FOR RESEARCH AND TEST REACTORS

Table 23.3.7

Facility

Name

중
Locaticn

Facility Type

NOT APPLICABLE 


\subsection{ECONOMIC RESOURCES FOR NUCLEAR POWER DEVELOPMENT}

ECONOMIC DATA PROFILE

Table 23.4 .1

$\begin{array}{llll}\text { GNP (Current million \$) } & -31,488(1977) & \text { Inflation Rate } & -10.1 \%(1977) \\ \text { Exports (million \$) } & -10,046(1977) & \text { Imports (million \$) } & -10,811(1977) \\ \text { Per Capita Income (\$) } & -564(1977) & \text { Disposable Income (\$) - } & 503(1975) \\ \text { Monetary Unit } & - \text { WON } & \text { Exchange Rate (/US\$) - } & 484(4 / 77) \\ \text { Population (million) } & -35.86(1976) & \end{array}$

In Millions of Dollars

1975

1976

Nucleàr Energy Research (budget, Ministry of Science and

Technology (MOST)

4.1

9.5

Other Energy Research

(budget for MOST)

Neg1.

0.4

The Summary Investment Plan in Energy Sector for 1977/81 has prescribed for total Energy $R \& D$ the amount of $\$ 90.7$ million. 
GOVERNMENTAL SUPPORTED NUCLEAR R\&D INDUSTRY, UNIVERSITIES

AND NATIONAL LABORATORIES

Table 23.4.3

\begin{tabular}{l} 
Industry \\
Unfversity or \\
Laboratory \\
\hline
\end{tabular}

Radiological Research Institute (RRI)

Korean Nuclear Engineering Services, Inc. (KNE)

Atomic Energy Research Institute (KAERI)
Korean Institute of Science and Technology (KIST)

Korea Nuclear Fue1 Development Institute (KNFDI)

\author{
Program \\ Area
}

Budget

\$ (Millions)

Performs all architect engineering services required for nuclear power projects

Neutron diffraction, radiation chemistry, wood plastics irradiation, cement plastics irradiation, plant breeding, control of diseases and pest insects on crops and livestock, preservation and piocessine of agrlcultural products, effacte of radiation on living organisms, radiation protection, medical application of radioactive isotopes

Conducta develnpment work which ran he utilized by Korean industry

Chemical technology, fuel fabrication, chemical analysis and instrumentation, contamination control of radioactive material and entire nuclear fuel cycle, ore refining and conversion
Young Ku Yoon President

Dr. Choo ChaiYang, Director 
GOVERNMENTAL SUPPORTED NUCLEAR R\&D INDUSTRY, UNIVERSITIES AND NATIONAL LABORATORIES

Table 23.4.3 (continued)

\begin{tabular}{|c|c|c|c|}
\hline $\begin{array}{l}\text { Industry } \\
\text { Unfversity or } \\
\text { Laboratory } \\
\end{array}$ & $\begin{array}{c}\text { Program } \\
\text { Area } \\
\end{array}$ & $\begin{array}{c}\text { Budget } \\
\$ \text { (Millions) } \\
\end{array}$ & $\begin{array}{c}\text { Key } \\
\text { Personnel } \\
\end{array}$ \\
\hline $\begin{array}{l}\text { Korea Research Institute } \\
\text { of Geoscience and } \\
\text { Mineral Resources } \\
\text { (KIGAM) }\end{array}$ & $\begin{array}{l}\text { Conducts geolog- } \\
\text { ical research } \\
\text { studies and ex- } \\
\text { ploration for } \\
\text { minerals, energy. } \\
\text { and water resour- } \\
\text { ces }\end{array}$ & - & - \\
\hline $\begin{array}{l}\text { Korea Atomic Indus- } \\
\text { trial Forum (KAIF), Inc. }\end{array}$ & $\begin{array}{l}\text { Training of nu- } \\
\text { clear personnel } \\
\text { and non-destructive } \\
\text { inspectors }\end{array}$ & - & $\therefore$ \\
\hline
\end{tabular}


There is little involvement by private Korean industry in energy $R \& D$.

R\&D work is carried out primarily in government supported institutions such as KAERI AND KIST.

There are three Korean companies, Hyundai, Dong Ah and Yu Yang, which have major roles as subcontractors in performing nuclear grade work. The government plans tn gradually substitute foreign technologlcal assistance with domestic ability:

ECONOMIC PROFILE OF REACTOR VENDORS AND FUEL CYCLE FACILITIES

Table 23.4 .5 
Korea relies heavily on foreign assistance. Financing total power in 1976 was accomplished through the following resources:

$\begin{array}{ll}25 \% & \text { Government Funds } \\ 12 \% & \text { Internal Cash Generation } \\ 19.6 \% & \text { Domestic Loans } \\ 42 \% & \text { Foreign Loans } \\ 1.4 \% & \text { Other Sources }\end{array}$

The government prefers to finance loans from as few sources as possible, but has to defer to the availability of loans from the supplier countries. This is complex because different portions of the nuclear units are supplied by different countries. They go to the United Kingdom, Canada and the U. S., but are considering France as another supplier for future units. The financial institutions assisting in payment of Korea's third plant are U. S. Export-Import Bank, Private Export Funding Corporation, Britain's Export Credit Guarantee Department and General Electric.

The long-term nuclear program will require $\$ 47.4$ billion (escalated) and the government plans are to cover half of those costs with foreign loans. KECO is studying a plan to issue foreign currency-denomination bonds for overseas markets as a way of raising construction money.

The loan to Korea for Kori-3 and Kori-4 ( $\sim 0.8$ billion) was, at the time of signing, the U. S. Export-Import Bank's largest such loan. The interest rate was $83 / 8 \%$ with a 15 year repayment term. An additional $\$ 180$ million was loaned to cover the uranium, enrichment and fabrication for the initial reactor fuel cores. This loan has a 3 year repayment period.

Currently U. S. and French reactor vendors are competing for the next two reactors (total foreign purchases $\sim \$ 1.4$ billion). It is believed that the French could offer the loan at $71 / 2 \%$ interest, while the U. S. Export-Import Bank offered $8 \%$. 
23.5 GOVERNMENT COMMITMENT AND ROLE IN NUCLEAR POWER DEVELOPMENT

\subsubsection{ENERGY POLICY - BASIC LEGISLATION}

Basic legislation on nuclear energy consists of 15 major laws dealing specifically with energy, including the Atomic Energy Law of 1958.

Office of Atomic Energy (OAE) established 1959

Atomic Energy Research Institute (AERI) established 1959

Radiological Research Institute (RRI) established 1966

Korea Atonic Industrial Forum (KAIF). Tnr. establiched 1972

Korea Atomic Energy Research Institute Law promulgated 1973

Korea Atomic Energy Research Institute established in 1973 incorporating AERI, RRI AND RRIA (Radiation Research Institute in Agriculture)

Office of Atomic Energy abolished and Atomic Energy Bureau established 1973

Dae-Duk Engineering Center established as branch institute of KAERI 1975

Established National System of Safeguards and International Cooperation. Directorate in MOST 1976. Ratified Treaty on the Non-Proliferation of Nuclear Weapons 1975.

Korea Nuclear Engineering Services, Inc. (KNE) established 1976

Korea Nuclear Fuel Development Institute (KNFDI) 1976 created from KAERI and reorganizing Dae-Duk. Engineering Center 
LEGISLATIVE - A unicameral National Assembly composed of 219 members. Two-thirds are elected by universal suffrage and one-third are appointed by the President.

EXECUTIVE - All real political power as well as executive authority is centered in the President (Chung Hee Park). The Deputy Prime Minister (Duck Woo Ham), who is concurrently chairman of the Economic Planning Board, is responsible for the overall national economic policy framework within which Korean energy programs operate. Ministries with energy responsibility include the Ministry of Science and Technology (MOST) which is responsible for licensing, regulation and supervision of nuclear power projects. However, the design, procurement, construction and operation of nuclear power plants is KECO's responsibility.

Various interagency committees, which include appointed non-ministry experts, play an advisory and review role. These include:

Atomic Energy Comnission (headed by Minister of Science and Technology) Electricity Development Coordination Committee (headed by the Deputy Prime Minister)

Korea's atomic power will be placed under a separate government owned corporation: the Korea Electric Company (KECO). KECO is to handle all affairs relating to the construction and operation of nuclear power plants. It will also deal with the procurement of nuclear fuel.

R\&D activities in nuclear fuel cycle were transferred from KAERI to KNFDI in December 1976. 
MINISTRY OF COMMERCE AND INDUSTRY (MCI)

Office of the Assistant Minister for Resources supervises all MCI energy activities.

Energy Development Bureau has the following divisions:

Energy Development

Oil Refining

Electric Power Generation

Rural Electrification

Mining Bureau is responsible for coal.

MCI aloo controls the Nallund Geological and Mineral Institute of Korea (GMIK).

MINISTRY OF SCIENCE AND TECHNOLOGY (MOST)

Atomic Energy Bureau reports directly to the Vice Minister of MOST.

Planning Division - Responsible for developing basic policies on enery source development, developing applications and utilization of atomic energy, and international cooperation.

Radiation Safety Division - Supervision of radiation and radioisotope handling, management of radiation and nuc.1,ear materials, licensing radinisntopes and othor matcrials.

Nuclear Reactor Division - Plans and implements policies for reactor development, management of fuels and reactors, compensation for nuclear damage and operation of the Nuclear Indemnity Council.

Resource Development Office is responsible for energy R\&D and gives dsslgnments to government supported research institutes such as:

Korea Atomic Energy Research Institute (KAERI)

Korea Institute of Science and Technology (KI.ST) 


\subsubsection{NUCLEAR ENERGY POLICY AND OBJECTIVES}

The objectives of the Fourth Five-Year Economic Development Plan (1977-1981) are as follows:

1. To establish a stable energy supp1y and demand system

2. To explore and utilize domestic energy resources to the maximum possible extent

3. To apply the science of energy utilization and saving of energy consumption in daily life

Since the beginning of FY 1977, government officials have renewed the call for a reduction in total energy consumption by $10 \%$.

As of 1978, official plans are for two more nuclear power plants, with capacity of $900 \mathrm{MW}$ each for completion by 1986. By then, Korea would have a combined nuclear power production capacity of 5.5 million kilowatts, accounting for $27 \%$ of the nation's overall power production target for that year.

\subsubsection{NUCLEAR ENERGY R\&D - STATUS AND OUTLOOK}

An ambitious program to install nuclear power plants is being pursued. Several plants are scheduled for completion during the next decade. Low grade uranium ore has been discovered. Officials believe that by the $1980^{\prime} \mathrm{s}$, production will be economically in line with rising international supply costs for enriched uranium.

\subsubsection{NUCLEAR ENERGY R\&D - PRIORITIES}

The established nuclear energy priorities are:

1. Development of nuclear power technology through local participation in design, construction, and operation phases of nuclear power projects.

2. Intensify exploration of uranium and thorium. 
23.5.7 ROLE OF GOVERNMENT IN NUCLEAR FACILITIES CONSTRUCTION AND OPERATION

The Atomic Energy Bureau has responsibility as follows:

Nuclear Reactor Regulatory and Licensing

1. Permission for the acquisition, production, import and export, construction, ownership, purchase and sale control and management and operation of nuclear reactor and facilities related.

2. Approval on design and method of work of nuclear reactor facilities.

3. Operation control of nuclear reactor facilities.

4. Security measures of nuclear reactor facilities.

5. License of nuclear reactor operators and sentor operators.

6. Management of Advisory Committee for Reactor Safety.

Nuclear Reactor Technology Division

1. Establishment of codes and standards for nuclear facilities.

2. Inspection of nuclear reactor and fuel facilities.

3. Audit for construction of nuclear reactor facilities.

4. Licensing of construction and operation for nuclear fuel facilities.

5. Licensing of nuclear materials. 
ENERGY GENERATION FACILITIES IN EXISTENCE AND FIRMLY PLANNED PRODUCING 100 MWe (net)

Table 23.6.1

Facility

Name

Hwachan

co Yongwol

曷 New Yongwo1

굳

焉

i. Soeul 3

Soeul 5

Pusan 1,2

Pusan 3,4

U1san Diese1

Incheon 1

Yeongnam 2

Seoul 4

Yeongdong 1
Utility/

Owner

Location

Korea Electric Co.

Korea Electr-c Co.

Korea Ilectric Co.

Korea Electric Co.

Korea Electric Co.

Korea Electric Co.

Korea Electric Co.

Zorea Electric Co.

Korea Electric So.

Rorea Electri: Co.

Eorea Electric Co.

Korea Electric Co.

క̌orea Electric Co.

\begin{tabular}{c}
$\begin{array}{c}\text { Ecility } \\
\text { Type } \\
\text { (T̄uel Type) }\end{array}$ \\
\hline
\end{tabular}

Hydro

Therma1

Tizerma1

Thermal

Thermal

Therma1

Therma1

T-erma1

$0 i 1$

Therma 1

Therma1

$\mathbb{T r}:$ rme1

Tr. $ə r m a 1$
Capacity

(MWe net) Status* COD

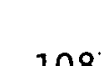

108

100

100

23

25

250

132

210

150

250

200

138

125

\section{0}

S $1973 \quad 1965$

0

0

0

$0 \quad 1969$

$0 \quad 1964$

$0 \quad 1968-69$

0

$0 \quad 1970$

$0 \quad 1970$

0 1970

0. 1972

* O-Operational; U-Under Construction; P-Planrec; S-Shutdown 
Table 23.6.1 (continued)

\section{Factlity}

Name

Yeosu 1

Yesngnam 1

Yeosu 2

Donghae 1

Kyungin Energy

Donghae 2

Honam

Donghae 3

Scyanggang

Ir.cheon 2

Yongwol, Kunsan

Ircheon 3,4

Iricheon -

Thermal Add.

\begin{tabular}{ll} 
Location & $\begin{array}{l}\text { Ltility/ } \\
\text { Owner }\end{array}$ \\
\hline
\end{tabular}

Korea Electric Co.

Koræa Electric Co.

Korea Electric Co.

Korea Electric Co.

Kyungin Energy Co.

Korea Electric Co.

Honam Power Co.

Babcock

Korea Electric Co.

(Private)

Korea Electric Co.

Korea Electric Co.

Korea Electric Co.

Korea Electric Co.

Vendor
* 0-Operationa1; U-Under Construction; P-Planned; S-Shutdown

\begin{tabular}{ll}
$\begin{array}{c}\text { Facility } \\
\text { Type } \\
\text { (Fuel Type) }\end{array}$ & $\begin{array}{l}\text { Capacity } \\
\text { (MWe net) }\end{array}$ \\
\hline
\end{tabular}

Thermal

200

200

300

220

325

220

600

220

200

250

Therma 1

Combined Cycle

600

650

300

Thermal

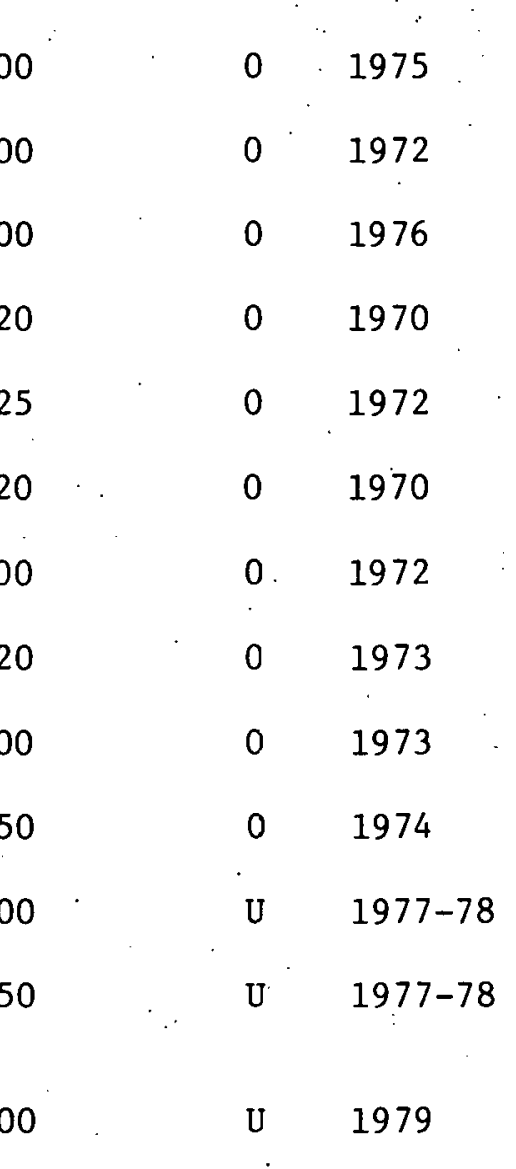


ENERGY GENERATION FACILITIES IH EXISTENCE AND FIRMY PLANMED ?F:DDUCING 100 MWe (net)

Table 23.6.1 (continued).

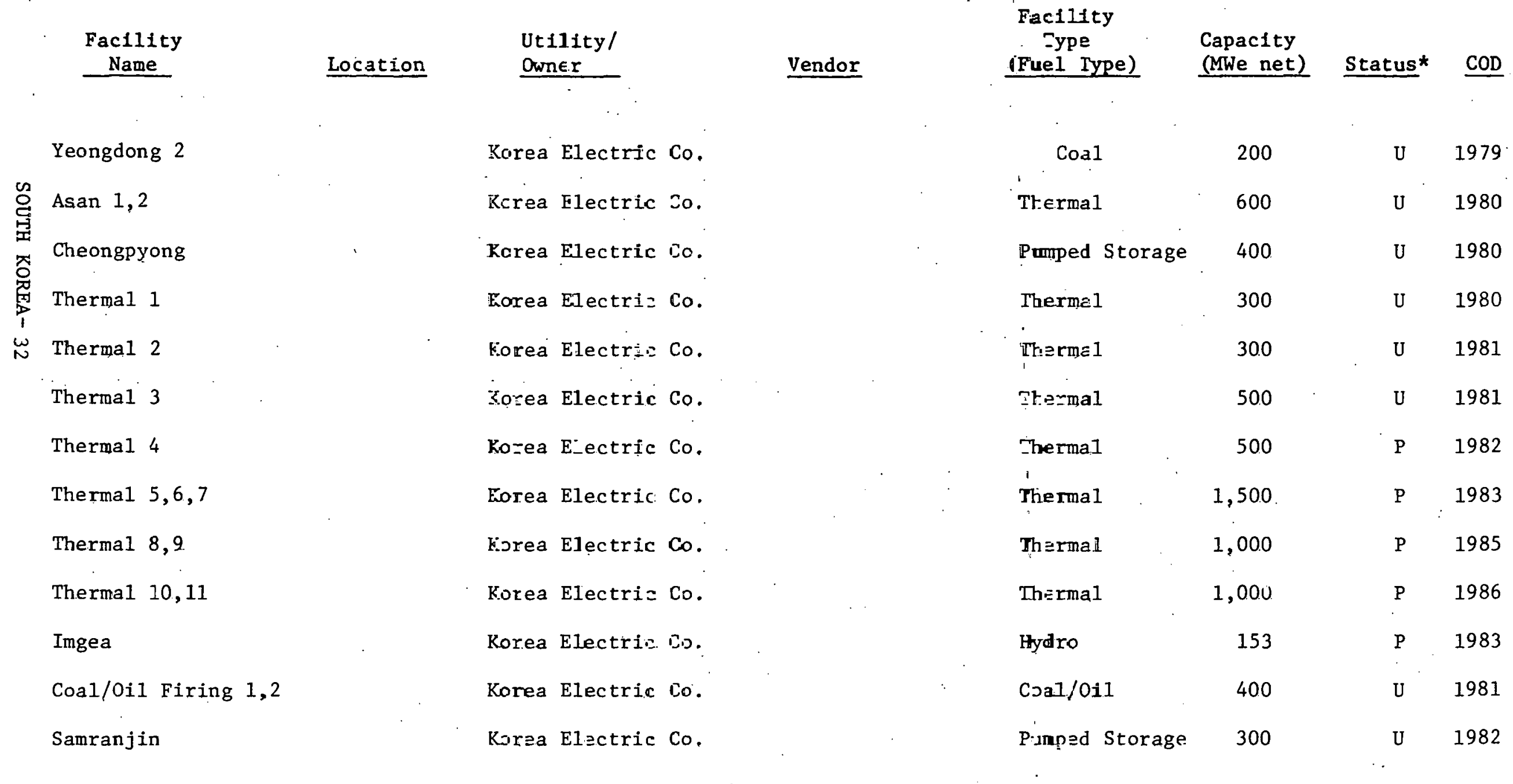

* O-Operational; U-Under Construction; P-Planned; S-Shutdown 
ENERGY GENERATION FACILITIES IN EXISTENCE AND FIRMLY PLANNED PRODUCING 100 MWe (nEt)

Table 23.6.1 (continued)

Faclitity

Name

Chungju

of Hapcheon

Hapcheon

Yongdam

Tilal
Uitility/

Location $\quad$ Owner

Korea Electric Co.

Korea Electric Co.

Korea Electric Co.

Korea Electric Co.

Korea Electric Co.

$$
\begin{gathered}
\text { Fac1lity } \\
\text { Type } \\
\text { (Fuel Type) } \\
\hline
\end{gathered}
$$

Vendor

Hydro

Hydro

Pumped Storage

Hydro

Hydro
Capacity

(MWe net) Status* COD 
SUMMARY OF ENERGY GENERATION FACILITIES IN EXISTENCE AND PLANNED

Table 23.6 .2

Year $\quad$ Capacity - MWe (net)

1975

5,135

1980

9,190

1985

17,774

1990

1995

2000 
LISTING OF FUEL SUPPLY FACILITIES IN EXISTENCE AND FIRMLY PLANNED.

Table 23.6 .3

Facility

Name

\section{Location}

$\left.\begin{array}{l}\text { Kangwonda } \\ \text { Cholla Namdo }\end{array}\right\}$
Dai. Han

Coal Corp./Private
Facility

Type

Capacity **

Status*

$\left.\begin{array}{l}\text { Coal Field } \\ \text { Coal Field }\end{array}\right\}$

13.5

0

0 
PROJECTIONS OF ENERGY SUPPLIES, IMPORTS AND EXPORTS

Table 23.6.4

COAL (million tonnes) Indigenous Supply

18.11

19.40

Imports

Exports

CRUDE OIL (million tonnes)

Indigenous Supply

32.6

Imports

$-$

Exports

SHALE OIL (million tonnes)

Indigenous Supply

Imports

Exports

NATURAL GAS (cubic kilometers)

Indigenous Supply

Imports

Fiports

URANTIIM (kilotonnes $\mathrm{U}_{3} \mathrm{O}_{8}$ )

Indigenous Supply

Imports

Exports

1.39

0

3.97

$0 \quad 0$


SECTION 24

SPAIN 


\section{INDIGENOUS RESOURCES}

Spain has approximately $13 \%$ of the total coal resources of southern Europe. These resources are put at 3,562 million tonnes of which 2,370 million tonnes are hard coal. Economically recoverable reserves total 1,643 million tonnes of which 907 million tonnes are hard coal (ref. 1.2). Spain's coal mines can provide $77 \%$ of Spain's domestic coal needs at present, and reserves are sufficient to expand this to $88 \%$ in the late 1980 's and after.

Crude oil is available from the Mediterranean Sea and current figures for quantities give the total resource as 24.2 million tonnes of which 11 million tonnes are economically recoverable. These figures have not been updated from a 1972 survey (see refs. 1.1 and 1.2).

Shale oil deposits are currently estimated at 12 million tonnes, this being the economically recoverable quantity. Shale oil production has been used for alleviating local oil shortage and no figure of total resource quantity is available.

A small amount of onshore natural gas is available (economically recoverable reserves being given as $0.65 \mathrm{~km}^{3}$, ref. 1.2). No figures are available for total resources nor for likely offshore quantities in the Mediterranean Sea.

Hydro-power is significant with a theoretical potential of 155 TWh of which 55 TWh is economically recoverable. It can provide $12-15 \%$ of primary energy needs in a good rainfall year, but can decline to $7 \%$ in drier years.

Spain's total indigenous uranium resources are estimated at 18.0 thousand tonnes, of which 8.0 thousand tonnes is considered economically recoverable.

\section{ENERGY SUPPLY}

Production of solid fuels was at the rate of 14.7 mil1ion tonnes (ref. 1.5) (14.1 million tonnes in ref. 1.2). Imports were given as 4.347 million tonnes in reference 1.5 , compared with 4.37 million tonnes in reference 1.6. As much as $56 \%$ is imported from the United States.

Crude oil production increased recently but still only stands at 2.24 million tonnes (ref. 1.5) compared with imports of 43.19 million tonnes. The figures given in reference 1.6 are 2.03 million tonnes and 42.3 million tonnes respectively. $95 \%$ of petroleum needs are imported.

Gas production is negligible, the total reserve not being sufficient to meet the annual demand.

Domestic production of uranium in 1975 was 187 short tons of $\mathrm{U}_{3}{ }^{0} 8.144$ short tons were imported, $100 \%$ from the U. S. A. 
PATTERNS OF ENERGY USE

Industry and power generation are the major sectors for coal demand.

Petroleum is consumed in all sectors, with industry demanding the largest percentage of the total.

Household consumption of natural gas is significant at about $33 \%$ of the total.

Industry is the prime consumer of electricity with over $50 \%$ of the total demand. A significant percentage of the overall demand is met by hydro-power and almost $10 \%$ by nuclear.

\section{FORECASTS OF ENERGY SUPPLY AND DEMAND}

Over the period 1965 to 1974 , the average annual rate of economic growth in Epain was $6.5 \%$ (1tef. 1.43) while in the same period, total primary energy demand increased at an average annual rate of $8.6 \%$ and electricity demand at a rate of $11.6 \%$ (refs. 1.5 and 1.44 ). The demand forecasts shown in Table 24.1 .4 indicate an average annual rate of energy demand growth from 1975 to 2000 of $4.1 \%$ to $5.3 \%$ and an electricity demand growth rate of $3.9 \%$ to $7.9 \%$. It should be noted that the new energy plan projects total primary energy consumption to go from 99.1 million tonnes of coal equivalent (2752[1012] Btu) in 1977 to 119.6 million in 1982 and 145.0 million in 1987. These projections lie near the high economic growth forecasts of Table 24.1.5.

A considerable growth of nuclear power capacity is expected, as can be seen from Table 24.1.5 (although much lower than even recent forecasts). This will reduce the dependence on oil and coal, however the absolute consumption of these fuels will continue to increase. The increase in coal consumption will be supplied partly by increasing the indigenous production of hard coal and partly by exploiting extensive lignitc resources for electricity generation (ret. 1.4\%). Coal imports are also expected to increase slightly since indigenous production will probably not increase fast enough to meet the growth in demand.

The total instalied nuclear capacity is expected to reach 16,909 MW by 2000 . 'l'he new energy. plan projects the following percentage supply of primary energy:

$\begin{array}{lrr} & 1982 & 1987 \\ \text { Coal } & 15.9 & 16.2 \\ \text { Crude Oil } & 59.5 & 54.3 \\ \text { Natural gas } & 4.6 & 5.3 \\ \text { Hydro Power } & 10.2 & 9.4 \\ \text { Nuclear Power } & 9.8 & 14.8\end{array}$

Comparison with the 1985 energy consumption projection in Table 24.1.5 indicates the new plan's movement away from nuclear energy towards crude oil and natural gas. In the new plan (not yet accepted) the nuclear percentage would drop from $32 \%$ to about $15 \%$, while the combined contribution of oil and gas would rise from $46 \%$ to almost $60 \%$. 
INDIGENOUS ENERGY RESOURCES

Table 24.1.1

Economically

Recoverable Reserves

Hard Coal (miilion tonnes)

Soft Coal (million tonnes)

Crude 0il (million tonnes)

Shale 011 (mfllion tonnes)

Natural Gas (cubi $=\mathrm{km}$ )

Uranium (thousand tonnes $\mathrm{U}_{3} \mathrm{O}_{8}$ )

Hydro Power (TWh/year)

Geothermal (TWh/sear)
907

736

11

12

0.65

8.0

55.0

0
Total Indigenous Resources

$$
\begin{aligned}
& 2,370 \\
& 1,192
\end{aligned}
$$

24.2

Not Available

Not Available

18.0

154.8

0
Location of Identified Reserves

Astur Pirenaica, Costera Catalana, Iberica

off shore

Cuenca de Sierra Morena

Cordoba, Salamanca 
ENERGY SUPPLY 1975

Table 24.1.2

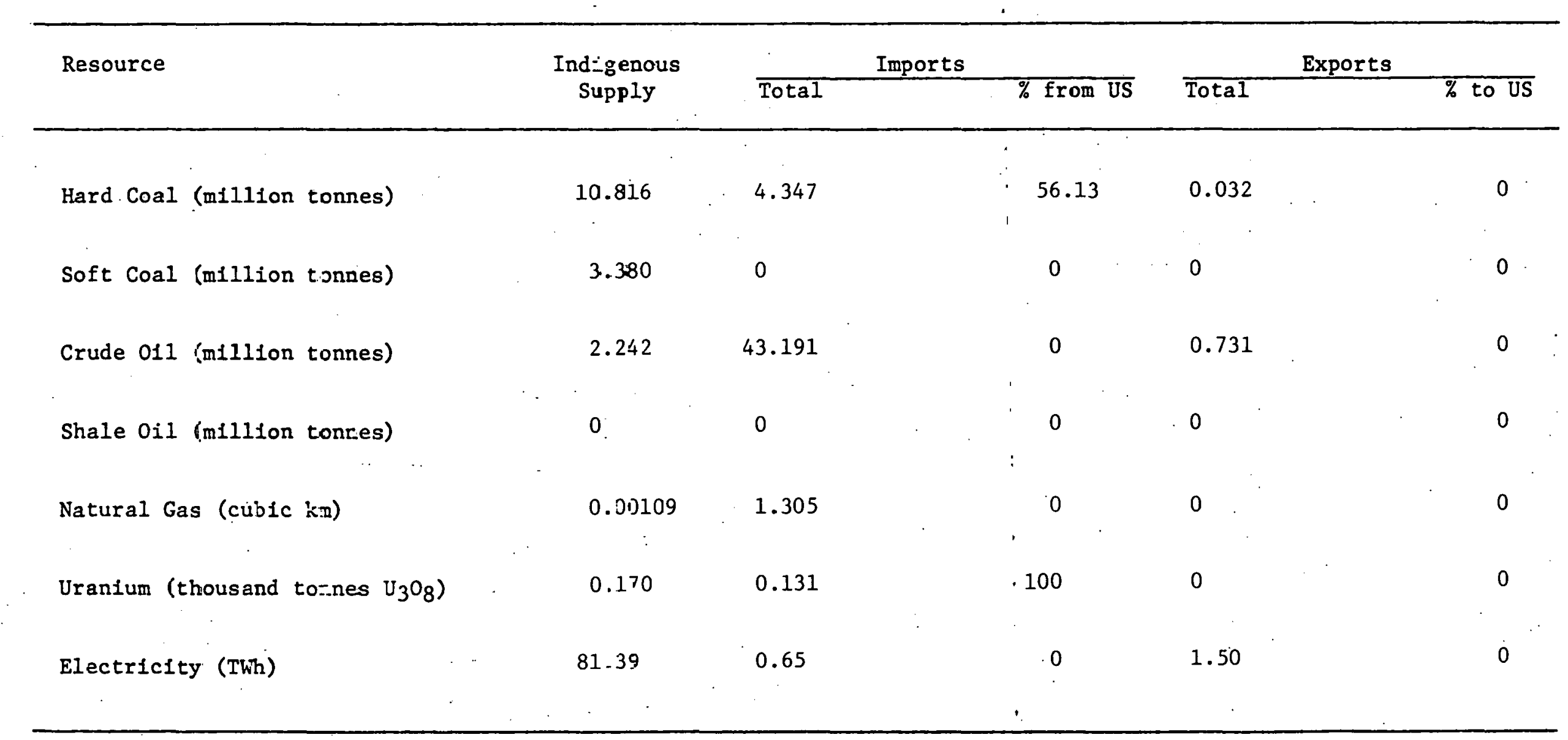




\section{PATTERNS OF ENERGY SOURCES AND USES 1975}

Table 24.1.3

\section{Consuming Sector}

Resource

Fousehold and

Commerclal

Industrial

Transportation

Electrical

Total

Generation

\begin{tabular}{|c|c|c|c|c|c|}
\hline Coal (million tonnes) & 0.26 & 9.64 & 0.03 & 6.43 & 16.36 \\
\hline Petroleum (m1llion tonnes) & 3.31 & 12.03 & 12.24 & 7.67 & 35.25 \\
\hline Natural Gas (cubic $\mathrm{kn}$ ) & 0.008 & 0.013 & 0 & 0.003 & 0.024 \\
\hline Nuclear Power ( $T$ Wh) & - & - & - & 9.0 & 9.0 \\
\hline Hydro Power (TWh) & - & - & - & 28.75 & 28.75 \\
\hline Geothermal Power (TW. $)$ & - & - & - & 0 & 0 \\
\hline & & & & . & . \\
\hline $\begin{array}{l}\text { Utility Electricity } \\
\text { Distributed (TWh) }\end{array}$ & 20.57 & 44.74 & 1.51 & 14.52 & 81.34 \\
\hline
\end{tabular}




\section{FCRECASTS OF ANNUAL ENERGY DEMAND AND ELECTRICITY LEMAND}

Table 24.1 .4

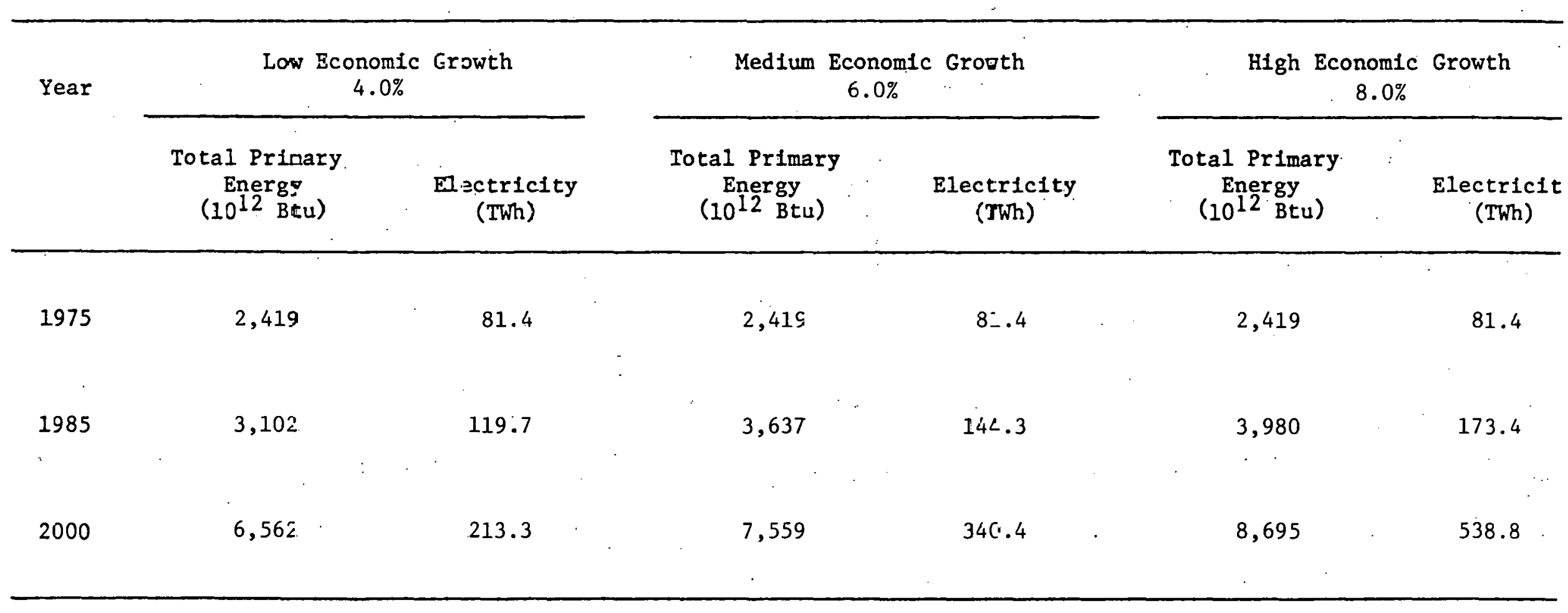




\section{CONSUMPTION OF ENERGY RESOURCES}

Table 24.1 .5

\begin{tabular}{|c|c|c|c|c|c|c|c|}
\hline \multirow[t]{2}{*}{ Resource } & \multirow[t]{2}{*}{ Standard Unit } & \multicolumn{3}{|c|}{$\begin{array}{l}\text { Annual Consumption of } \\
\text { Standard Units }\end{array}$} & \multicolumn{3}{|c|}{$\begin{array}{l}\text { Energy Consumption } \\
\quad\left(10^{12} \mathrm{BtU}\right)\end{array}$} \\
\hline & & 1975 & 1985 & 2000 & 1975 & 1985 & 2000 \\
\hline & $\therefore$ & & & & & & \\
\hline Coal & Million Tonnes & 16.83 & 17.8 & 28.1 & 467.3 & 493 & 781 \\
\hline Crude 011 & Million Tonnes & 34.71 & 38.5 & 77.3 & $1,473.1$ & 1,634 & 3,277 \\
\hline Natural Gas & Cublc km & 1.37 & 0.6 & 0.4 & 49.1 & 20 & 15 \\
\hline Hydro Power & TWh & 28.75 & 30.1 & 34.0 & 327.0 & 342 & 387 \\
\hline & 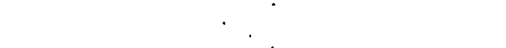 & & & & & & \\
\hline Other Renewables & IWh & - & - & - & - & - & - \\
\hline Nuclear Power & TWh & 9.00 & 100.9 & 272.3 & 102.4 & 1,148 & 3,099 \\
\hline Uranium & $\therefore$ Thousand Tonnes $\mathrm{U}_{3} \mathrm{O}_{8}$ & 1.51 & 1.89 & 3.25 & - & - & - \\
\hline
\end{tabular}


24.2 NUCLEAR HISTORY, CAPABILITY, COMMITMENT AND TRENDS

\section{COMMERCIAL NUCLEAR POWER PLANTS}

Table 24.2.1

\begin{tabular}{|c|c|c|c|c|c|c|}
\hline $\begin{array}{l}\text { Facility } \\
\text { Name } \\
\end{array}$ & Utility & Vendor & $\begin{array}{c}\text { Facility } \\
\text { Type }\end{array}$ & $\begin{array}{l}\text { Capacity } \\
\text { (MWe net) }\end{array}$ & Status* & COD \\
\hline Almaraz $1^{\circ}$ & $\begin{array}{l}\text { Central Nuclear } \\
\text { de Almaraz }\end{array}$ & Westinghouse & PWR & 902 & $\mathrm{U}$ & Jul 1979 \\
\hline Almaraz 2 & $\begin{array}{l}\text { Central Nuclear } \\
\text { de Almaraz }\end{array}$ & Westinghouse & PWR & 902 & $\mathrm{U}$ & Ju1 1980 \\
\hline Vandellos 1 & HTFRENSA & CEA & Magnox & 484 & 0 & May 1972 \\
\hline $\begin{array}{c}\text { Asco } 1 \\
.\end{array}$ & $\begin{array}{l}\text { Fuerzas } \\
\text { Electricas de } \\
\text { Catalona }\end{array}$ & Westinghouse & PWR & 902 & U & Jun 1980 \\
\hline Asco 2 & $\begin{array}{l}\text { Asociacion } \\
\text { Nuclear de } \\
\text { Asco-2 }\end{array}$ & Westinghouse & PWR & 902 & $u$ & Jun 1982 \\
\hline Cofrentes & $\begin{array}{l}\text { Hidro Electrica } \\
\text { Espanola }\end{array}$ & GE & BWR & 930 & U & JuI 1981 \\
\hline Lemoniz 1 & Iberduero & Westinghouse & PWR & 883 & II & Dec 1979 \\
\hline Lemunif 72 & Ibcrduero & Westinghouse & PWR & 883 & $\mathrm{U}$ & Nov 1981 \\
\hline Sayago & Iberduero & Westinghnuse & PNR & 1034 & $P$ & JuL 1986 \\
\hline St. Maria & $\begin{array}{l}\text { Central Nuclear } \\
\text { de] Nortc }\end{array}$ & $\mathrm{GE}$ & BWR & 440 & 0 & May 1971 \\
\hline J. Cabrera & Union Electrica & Westinghouse & PINR. & 153 & 0 & Aug Iyby \\
\hline Trillo & Union Electrica & KWU & PWR. & 985 & $P$ & Jun 1988 \\
\hline Valdecab, 1 & $\begin{array}{l}\text { Central Nuclcar } \\
\text { de Valdecabelleros }\end{array}$ & GE & BWR & 937 & $\mathrm{P}$ & Jun 1984 \\
\hline
\end{tabular}

* O-Operational; U-Under Construction; P-Planned 


\section{PROJECTED NUCLEAR GENERATING CAPACITY}

MWe (net)

Table 24.2 .2

\begin{tabular}{|c|c|c|c|c|c|c|c|c|c|}
\hline Year & PWR & BWR & Magnox & AGR & CANDU & Other & FBR & $\begin{array}{l}\text { Firm }+ \\
\text { Planned } \\
\text { Cumulative } \\
\text { Total } \\
\end{array}$ & $\begin{array}{c}\text { NAC } \cdot \\
\text { Cumulative } \\
\text { Projection } \\
\end{array}$ \\
\hline pre-1978 & 153 & 440 & 484 & & & & & 1077 & 1077 \\
\hline 1978 & & & & & & & & 1077 & 1077 \\
\hline 1979 & 1785 & & & & & & & 2862 & 3764 \\
\hline 1980 & 1804 & & & & & & & 4666 & 4666 \\
\hline 1981 & 883 & 930 & & & & & & 6479 & 6479 \\
\hline 1982 & 902 & & & & & & & 7381 & 7381 \\
\hline 1983 & & & & & & & & 7381 & 7381 \\
\hline 1984 & & 937 & & & & $\therefore$ & & 8318 & 8318 \\
\hline 1985 & . & & & & & & & 8318 & 8318 \\
\hline 1986 & 1034 & & & & & & & 9352 & 9352 \\
\hline 1.987 & 930 & & & & & & & 9352 & 10282 \\
\hline 1988 & 985 & & & & & & & 10337 & 11267 \\
\hline 1989 & & & & & & & & 10337 & 11267 \\
\hline 1990 & & 937 & & & & & & 10337 & 12204 \\
\hline 1991 & & & & & & & & 10.337 & 12204. \\
\hline 1992 & 985 & & & & & & & 10337 & 13189 \\
\hline 1993 & & & & & & & & 10337 & 13189 \\
\hline 1994 & 930 & & & & & & & 10337 & 14119 \\
\hline 1995 & & & & & & & & 10337 & 14119 \\
\hline 1996 & 930 & & & & & & & 10337 & 15049 \\
\hline 1997 & & & & & & & & 10337 & 15049 \\
\hline 1998 & & 930 & & & & & & 10337 & 15979 \\
\hline 1999 & & & & & & & & 10337 & 15979 \\
\hline 2000 & 930 & & & & & & & 10337 & 16909 \\
\hline
\end{tabular}

Notes: The revised Spanish energy plan reduced the nuclear component from 8 reactors (not now under construction), authorized for operation by 1987 , to 3 . This is shown above. The plan has yet to be approved, however the actual 1978 GNP and electricity demand growths considerably exceeded the projected growths upuil which the new plan was based. 


\section{Overview}

Spain currently possesses no nuclear reactor vendors. However, Westinghouse has been active in Spain since the early 1960's and in 1971 Westinghouse Nuclear Espanola was set up with the aim of project management and maximizing Spanish participation in Westinghouse projects. The organization has been expanded to cover a wider range of activities including nuclear engineering and marketing in Spain and the majority of personnel are Spanish. Westinghouse has entered into a number of license agreements for the manufacture in Spain of major nuclear components, nuclear fuel and nuclear turbine generators.

Based on ENSA (see below) the potential exists for the setting up in the future of a national organization (sale and/or private industry) for the domestic and export of nuclear power plants based un license. agrepmente.

Nuclear Reactor Vendor Support Industries

Since the first nuclear reactors were constructed in Spain, local industry has made, partly through license agreements, an increasing contribution. For the first plants it lay around $40 \%$, for the reactors currently under construction it is around $60 \%$ (35\% of steam generating plant) and for the future $80-85 \%$ local supply is foreseen. Therefore, Spanish industry is already able to supply a significant range of components and equipment for nuclear reactors and the activity is increasing.

For the main components the most important company is Empresa Equipos Nucleare S.A. (ENSA) which was formed in 1972 for the manutacture of complete N333 sels for Westinghnuse, GE and KWU reactore (prcosure vessels, steam generators and related items). A license agreement exists with Westinghouse and technology transfer agreements with GE and KWU. The current sharphniding cunsists of! Babcock and Wilcox Espanola 35\%, La Manquinista Terrestre y Maritima 34\%, Mecanica de 1.a Pena 9\%, Stein ct Koubaix Espann1a 9\%, Spanioh utilities 15\%. A Guvernfient decree in 197\% gave thw sumpany the chardictelsules of a "priority national interest"; it is thus the single authorized supplier of nuclear island equipment in Spain. Construction of a new manufacturing facility at Santander started in 1974 and vessel manufacturing has already commenced. The second phase of the facility wil1. be completed in 1980 .

The initial target capacity for ENSA is three NSSS sets per year by 1980 and eventually four sets per year. The first pressure vessel to be manufactured is for the GE BWR Valdecaballeros-1 plant for delivery in 1978. For the first two vessels, Breda Termomeccanica of Italy will supply some pre-fabricated parts. 
Thereafter, Spanish manufacture will virtually reach the $100 \%$ level. Initially ENSA will subcontract rolled plates and forgings (e.g. to B\&W Expanola), later plate bending machines will be installed. The first completely Spanish steam generators will be produced for the KWU PWR Trillo-1 plant.

Shop crane capacity is 900 tons and complete pressure vessels can be loaded directly onto ships. 


\section{Overview}

Spain is involved in the fuel cycle in a major way. There are two operating $\mathrm{U}_{3} \mathrm{O}_{8}$ mines/mills. The oldest and smallest mine at Andujar (near Cordoba) is owned $100 \%$ by the Junta de Energia Nucleare (JEN). This plant has been operating since 1959. The second mine/mill complex is the Ciudad Rodrigo complex at Salamanca which is owned $100 \%$ by Empresa Nacional del Uranio S.A. (ENUSA). This complex began operation in 1975. Private industry is planning to undertake the extraction of uranium from phosphates. A major effort is being made to maximize domestic uranium production.

JEN is a highly influential government body which has the responsibility for many nuclear decisions including safety, site 11censing and the domestic uranium exploration program. JEN currently advises ENUSA which was set up in $19 / 2$, to provide fuel services. ENUSA is owned $60 \%$ by the Spanish government and $40 \%$ by utilities. It has the sole responsibility for nuclear fuel and nuclear fuel services in Spain.

Because the major part of Spantsh urantum requirements must be met from imports ENUSA has 10\% ownership of COMINAK, a 2,360 tonnes $\mathrm{U}_{3} \mathrm{O}_{8} /$ year mine/mill complex in Niger scheduled for operation in 1979. In addition, ENUSA is involved in uranium exploration activities in Colomb1a, Canada, Ch1le, and South Africa.

ENUSA has financial interests in both the Eurodif and Coredif cnrichment projecto in France. For the detailo of Eurodif and Coredif see under France. In summary, ENUSA holds an $11.11 \%$ interest in Eurodif and through Eurodif a $5.67 \%$ interest in Coredif.

ENUSA is planning the construction of an LWR fuel fabrication facility. License agreements for the design and manufacture of fuel have been obtained from Westinghouse, GE and KWU. A construction pcrmit for a site at Juzbada, Salamanca Province has been requested trom the Government but this is currentiy being delayed. It is intended that eventualiy all fuel for Spanish LWR's will be manufactured by ENUSA.

ENUSA and JEN are studying the feasibility of a national reprocessing plant. JEN has been involved in reprocessing research for many years and has carried out the reprocessing of test reactor fuels. The search for a site for a reprocessing plant/ intermediate fuel storage facility is underway.

The main current and planned facilities are summarized in Table 24.2 .3 . 


\section{CURRENT AND PLANNED FACILITIES}

Table 24.2 .3

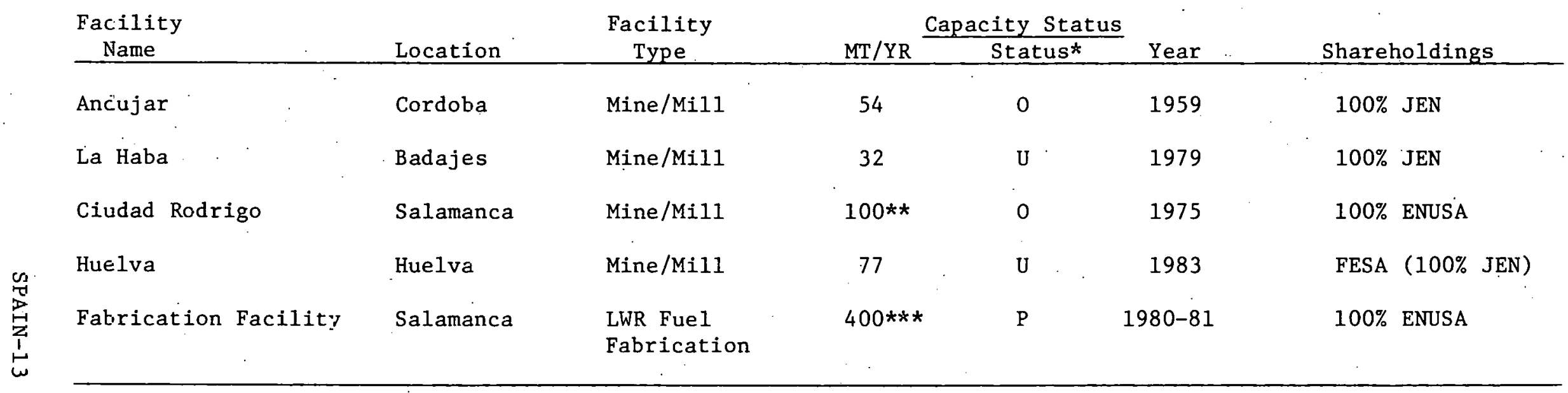

* O-Operational; U-Under Construction; P-Planned

* Capacity expansions under consideration for completion in 1981. At that time capacity will be $460 \mathrm{MTU} / \mathrm{year}$.

*** Will commence with assembly and successively add pellet and powder production 
Andujar is a very small mining and milling complex which has been in operation since 1959. Mining is by the open pit method. Milling technology was developed domestically, the specific process is not known.

The current capacity is 65 tonnes $\mathrm{U}_{3} \mathrm{O}_{8}$ (54 tonnes $\mathrm{U}$ ) per year. The operation is not economic since ore has to be transported from the surrounding area. It is only expected to operate for another $2-3$ years.

All production is delivered to ENUSA to be used to fuel domestic reactors.

The amount of uranium produced by Andujar is not known but is estimated to be less than 1150 tonnes $\mathrm{U}_{3} 0_{8}$ through 1976. For the pást tive years it has been producing 54-65 tonnes per year.

As the Andujar complex is shut down, production from the new La Haba mine/mill complex will be phased in to replace Andujar production. La Haba will have a capacity of about 32 MTU per year, and is scheduled to be in operation in late 1979. 
Facility: Ciudad Rodrigo Uranium Mining and Milling

Ciudad Rodrigo is a modest mining and milling complex which entered into operation in 1975. Mining is by the open pit method. Currently uranium is extracted from ore by pit leaching but a continuous dynamic extraction system is now under construction.

Current capacity is 118 tonnes $\mathrm{U}_{3} 0_{8}$ ( $100 \mathrm{MTU}$ ) per year. The new dynamic extraction system expansion will increase the capacity to approximately 545 tonnes $\mathrm{U}_{3} \mathrm{O}_{8}$ per year and will enter operation in 1981. The mining/milling complex is anticipated to have a 20 year lifetime.

All production is reserved for use in domestic reactors.

It is estimated that Ciudad Rodrigo produced approximately 180 tonnes of $\mathrm{U}_{3} \mathrm{O}_{8}$ through 1976 .

Facility: Huelva Uranium Mining and Milling

The facility will recover uranium from phosphate rock imported from Morocco and the Spanish Sahara. The facility's capacity is planned for $100 \mathrm{STU}_{3} \mathrm{O}_{8}$ ( $80 \mathrm{MTU}$ ) per year. It was preceded by a small test laboratory in 1969 and then by a pilot plant. Successful operation led to the division to construct the commercial facility. All production will be committed to ENUSA. Initial operation is scheduled for 1983. 
NUCLEAR DEVELOPMENT OUTLOOK SUMMARY

Vested Interests in Current Fuel Cycles and Reactor Technologies

Spain has a major vested interest in both current reactor technology and in the fuel cycle.

While slippage has occurred, and a new energy plan has tentatively lowered the number of approved reactors, Spain still has an ambitious nuclear program aimed at reducing dependence on oil. It has a large number of LWR's under construction or ordered, and is rapidly achieving the industrial capability to be practically self-sufficient for the complete supply of LWR power plants (NSSS and nuclear turbine design and manufacture). Spanish industry is generally well organized and capable of supplying a wide range of components and equipment. Modern facilities for the manufacture of complete NSSS sets have been constructed and have entered operation. There is clearly a massive national commitment to LWR technology.

In the fuel cycle, Spain has made a major commitment by way of its participation in the Eurodif and Coredif enrichment project. Selfsufficiency in LWR fuel fabrication is planned within the next few years. There is no current investment in reprocessing but this is planned for the future.

Current Trends in Nuclear Development Programs

For the near mid-term, the emphasis is clearly on attaining the highest degree possible of self-sufficiency in the supply of LWR power plants and associated fuel services. There is apparently no large-scale domestic involvement in advanced technologies and 1t can be envlsaged that Spain.will look to more advanced nations to provide proven technology which the experienced domestic industry will supply and manufacture under license or cooperation agreements. 
24.3 NUCLEAR TECHNOLOGY CAPABILITY AND RESOURCES

\section{PROFESSIONAL LABOR FORCE PROFILE}

Table 24.3.1

Available information presents the following data for 1972:

8,945 Scientists and Engineers

engaged in $R \& D$

KEY TECHNICAL EDUCATIONAL RESOURCES

Table 24.3.2

\section{Institution}

University of Salamanca University of Valladalid University of Barcelona University of Valencia University of Santiago de Compostella University of Seville University of Madrid University of Granada University of Saragossa

University of Oviedo University of La. Paguna University of Murcia University of Bilbao University of Navona University of Duesto University of Salamanca

\section{$\underline{\text { Location }}$}

Salamanca

Valladalid

Barcelona

Valencia

Santiago de Compostella

Seville

Madrid

Granada

Saragossa

Oviedo

Canary Islands

Murcia

Bilbao

Pamplona

Billbao

Pontifical 
Table 24.3.3

\section{Name}

Junta de Energia Nuclear (JEN)

Juan Vigon Nuclear

Research Center
Location

Madrid

Moncloa, Madrid
Main Activities

Development of fundamental nuclear research and. nuclear technology

Spain's major nuclear R\&D center

- basic research and isotope production

- fast reactor experiments

- $\mathrm{U}_{3} \mathrm{O}_{8}$ milling research

- reactor fuel production

- PU processing

- waste treatment 
KEY PRIVATE NUCLEAR RESEARCH ORGANIZATIONS

Table 24.3 .4

Name

Owner

Location

Main Activities

No major private rəsearch organizations exist in Spain. Most private organizations are primarily oriented towards commercial applications, with little structure or incentive for significant R\&D activity. 


\section{RESEARCH AND TEST REACTORS}

L1st of Reactors

\section{Table 24.3.5}

\section{Facilizy Name}

JEN-1

JEN-2

CORAL-1

ARBI

ARGOS

\section{Location $\cdots$ Owner}

Nuc_ear Resəerch Ctr, JEN

$"$

Eilbac

Barcelcha
JEN

JEN

Bilbao Superior Technical School

Barcelona Superior

Technical School

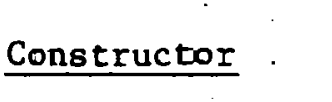

Facility

Type

GE \& JEY

JEN

JEN

EN

JEN
Facility Status MW(th) Status* COD

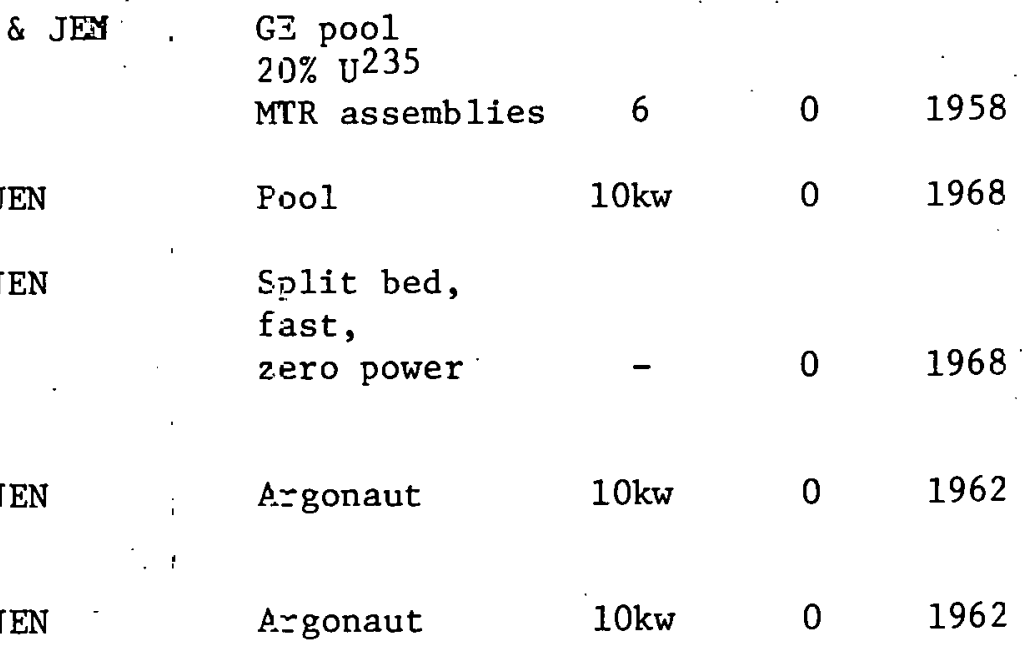

* 0-Operational; U-Under Construction; P-Planned; S-Shutdom 
INDIGENOUS CAPABILITY TO DESIGN AND SUPPLY RESEARCH AND TEST REACTORS AND FUEL SERVICES Summary of Reactor Orders by Vendor and Country

Table 24.3.6

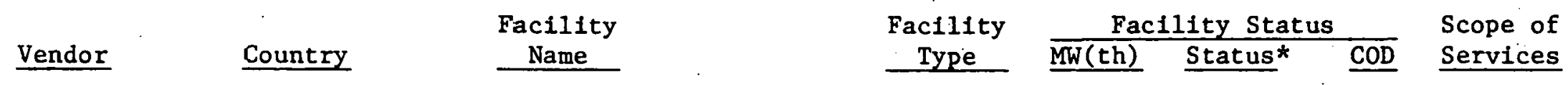

See Table 24.3.5 for research reactors

constructed by JEN which are used domestically.

* O-Operational; U-Under Construction; P-Planned; S-Shutdown 
SUMMARY OF FUEL SERVICES FOR RESEAFCH AND TEST REACTORS

Table 24.3 .7

\section{Fac1lity \\ Name}

JEN

$\frac{\text { Facility }}{\text { Type }}$
Fabrication
of Piates

$\frac{\text { Capacity Status }}{\text { ST/YR }} \frac{\text { Status* }}{\text { Year }}$
$\begin{aligned} & \text { Quantity for } \\ & \text { one research reactor }\end{aligned}$

one research reactor

JEN, at the National Res $\equiv a r c h$ Center, has $\mathrm{p}$ ilot facilities for $\mathrm{U}_{3} \mathrm{O}_{8}$ purification, production of metallic, carbide and oxide fuel rads: plistonium processing, and waste treatment. These facilities could produce research and test reaetor fuel. 
ECONOMIC DATA PROFILE

Table 24.4 .1

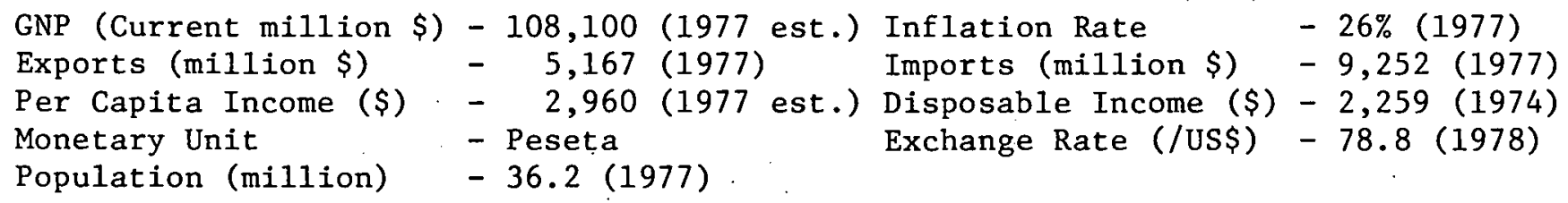

\subsubsection{GOVERNMENTAL NUCLEAR ENERGY R\&D BUDGET}

While the total government energy R\&D budget increased from 34 million dollars in 1974 to 42 million dollars for the year 1977 , the nuclear fission budget remained relatively constant (in terms of dollars) at about \$19 million. Other research budgets, particularly conservation, geothermal and solar, have dramatically increased during this period. 
GOVERNMENTAL SUPPORTED NUCLEAR RED INDUSTRY, UNIVERSITIES

AND NATIONAL LABORATORIES

Table 24.4 .3

Industry

Unfversity or

Laboratory

Program

Budget

Key

\$ (Mililons)

Personnel

National Institute of Industry

Energy applications

Empreso Nacional

Mining tech- nology

Sobria Nuclear

Energy Center

Designing fuel elements, materials' development, irradiated fuel behavior (under construction)

Energy Studies Center

Laboratory for Nuclear Applications of Puhlic. Works 
Through international agreements, indigenous technical research and mechanical engineering is increasing.

In permits issued by the Ministry of Industry, a clause requires that Spanish manufacturing and engineering firms should perform a specified percentage of work in carrying out the project. The government is aiming toward $80-85 \%$ Spanish participation.

Formation of large contracting firms has led to rapid assimilation of relevant technology

1. boiler and mechanical equipment

2. electrical and electronic equipment

3. civil work and erection

4. engineering services

ECONOMIC PROFILE OF REACTOR VENDORS AND FUEL CYCLE FACILITIES

Table 24.4.5

Name

Share Capital

Assets

Sales

There are no Spanish reactor vendors. JEN and ENUSA own the two operating $\mathrm{U}_{3} \mathrm{O}_{8}$ mines/mills. Spain has financial interests in both Eurodif and Coredif enrichment projects and is planning construction of a LWR fuel fabrication facility. 
Export-Import Bank has provided loans for U.S. supplied reactors while other U.S. banking institutions have made loans available for additional purchases of U.S.-made nuclear power plant equipment. Similar arrangements have been made in France and West Germany for reactors supplied by these countries. 
24.5 GOVERNMENT COMMITMENT AND ROLE IN NUCLEAR POWER DEVELOPMENT

24.5.1 ENERGY POLICY - BASIC LEGISLATION

Law of 29 November 1939 established the Higher Council for Scientific Research

Law of 17 October 1951 established the Spanish Nuclear Energy Board which prepared the Spanish Nuclear Plan

Nuclear Energy Commission formed to act as advisory body to government nuclear power in 1951

Law of 22 September 1961 set up non-profit making Research Associations which are promoted by trade groups. A typical example is the Research Association of the Electricity Industry.

Decree of 16 October 1964 created the National Fund for the Development of Scientific Research. The fund is in turn controlled by the Advisory Commission for Scientific and Technical Research, created by decree on 7 February 1958

A1l plans for construction of new electricity generating plans under joint program, "NATIONAL ELECTRICITY SUPPLY PROGRAM." (Second version issued 1972.)

ENUSA was formed for purposes of manufacturing nuclear fuel elements and engaging in all activities of full cycle in 1971.

Government decree, law 2656 of 1972, brought Equipos Nucleares SA into being which made them single authorized supplier for nuclear islands under the entire large nuclear capacity installation program

Decree of 10 December 1974 created the Center of Energy Studies depending on the Ministry of Industry and Energy. This Center is responsible for developing energy conservation measures and carrying out studies on energy development

Decree of 21 July 1974 established the possibility of joint R\&D activities in the nuclear field between power companies and the Nuclear Energy Board

Energy Plan approved by the Spanish Government in 1975

1975 - National Power Supply Plan approved and subject to review every two years

National Energy P1an was submitted October 1978, but has been shelved until the general elections are held on March 1, 1979, as well as the municipal elections in April. 
LEGISLATIVE - A unicameral Parliament called the Cortes dominated by the executive (constitutional reform underway to establish a bicameral legislature).

EXECUTIVE - The monarch King Juan Carlos I serves as Head of State. In July 1969, then Prince Juan Carlos de Borbon was sworn in as successor to the Head of State, and following General Franco's death in November 1975, took the oath as King of Spain. Executive authority technically lies with the king, though his acts are subject to countersignature. More likely to dominate all branches of government through his position as Chief of Government is the Prime Minister.

The controlling power in the energy field lies primarily within two iululslifes:

1. Ministry of Industry and Energy - Rodriguez Sabagun

2. Ministry of Education and Science

Under the Ministry of Industry and Energy, the following subdivisions exist to facilitate government control in the energy field and participation in the private sector:

- Nuclear Energy Board -- responsible for all nuclear-related activities, including the formulation of nuclear energy policy and R\&D programs

- Comnission of Energy and Mines

- Commisston of scientific Policy

- Nuclear Energy Commission -- Center for research, expert advisors to government and as a body concerned with safety and protection against ionizing radiations. To encourage industrial development in application of nuilear jower

- Nuclear Security Council (see government role in construction and operations) 
Primary responsibility for implementation of all energy policy and R\&D rests with the Ministry of Industry and Energy, though there are separate organizations for the nuclear and non-nuclear sectors.

Nuclear Energy Board -- Umbrella organization for all nuclear-related activities. The following subdivisions contribute to the overall nuclear energy program:

- Commisariat of Energy and Minerals;

- Research Associations;

- Junta de Energia Nuclear (JEN) -- created in 1951 and responsible for providing advice on all matters related to atomic energy; inspection of nuclear facilities for safety; uranium prospecting and exploitation; training; and research and development;

- Institute of Nuclear Studies -- Director, Amando Duran Miranda;

- Instituto Nacional de Industria (INI) -- created in 1941 as a government holding agency for all petroleum-related activities. Headed by President Don Juan Antonanzas, the Institute grants permits for foreign involvement in the exploration and production of oil. Under this organization are:

a. Enagas - established to control the importation of gas and the construction of pipelines (natural gas);

b. Empresa Nacional Carbonera del Sur;

c. Empresa Nacional Hullera del Norte, S.A. (HUNOSA);

d. Empresa Nacional del Uranion, S.A. (ENUSA) -- supervises exploration for uranium under the direction of its President, Xavier Saques.. Though Spain's nuclear plants are privately owned and operated, INI acts in a consultative role. 
The previous Spanish energy plan contemplated that nuclear energy would make up about $30 \%$ of its primary energy consumption by 1985 . The new plan (not yet approved) calls for a more modest $15 \%$.

The nuclear objectives of the JEN are in the areas of:

- uranium ore prospecting

- nuclear fuel cycle

- nuclear reactor technology

- fundamental and applied research

- nuclear safety and radiation protection

- technical training 
R\&D in such areas as petroleum, coal, nuclear power, hydroelectric power, power transmission and natural gas is well established and it is anticipated that $R \& D$ in nuclear power production will increase significantly.

NUCLEAR FISSION R\&D

- Development of fuel handling equipment for nuclear power stations

- R\&D in prospecting methods for uranium ore deposits

- Development of chemical processing techniques of uranium ores containing lignite and phosphore

- Techniques of fuel elements fabrication and reprocessing

FAST BREEDER R\&D

- Studies on fast breeder reactors

- Technology of materials

- Development of sodium loops for thermohydraulic tests and corrosion studies

NUCLEAR FUSION R\&D

- Fundamental research on laser fusion

- Studies on plasma confinement

24.5.6 NUCLEAR ENERGY R\&D - PRIORITIES

Established nuclear energy priorities are:

- fast breeder technology

- nuclear fuel cycle, including indigenous fabrication and reprocessing capability 
The Ministry of Industry authorizes construction, erection and commissioning of nuclear installations. The procedure is as follows:

A construction application is submitted to the Nuclear Energy Commission which advises the National Energy Authority on its suitability. The National Energy Authority issues a preliminary authorization and the Nuclear Energy Commission issues a preliminary technical assessment. The building permit is issued by the National Energy Authority which will set up a joint coordinating committee consisting of

1. representatives of government

2. local authorities concerned

3. JEN

4. operating company

The National Energy Authority gives provisional approval for commissioning of plant and formal operating license. Then the Ministry of Industry will inspect the plant and authorize start up.

Nuclear power plants are privately owned and operated, but the INI maintains a consultative role. 
ENERGY GENERATION FACILIZIES IN EXISTENCE AND FIRMEY PLANNED PFDDUCING 100 MWe (net)

Table 24.6.:

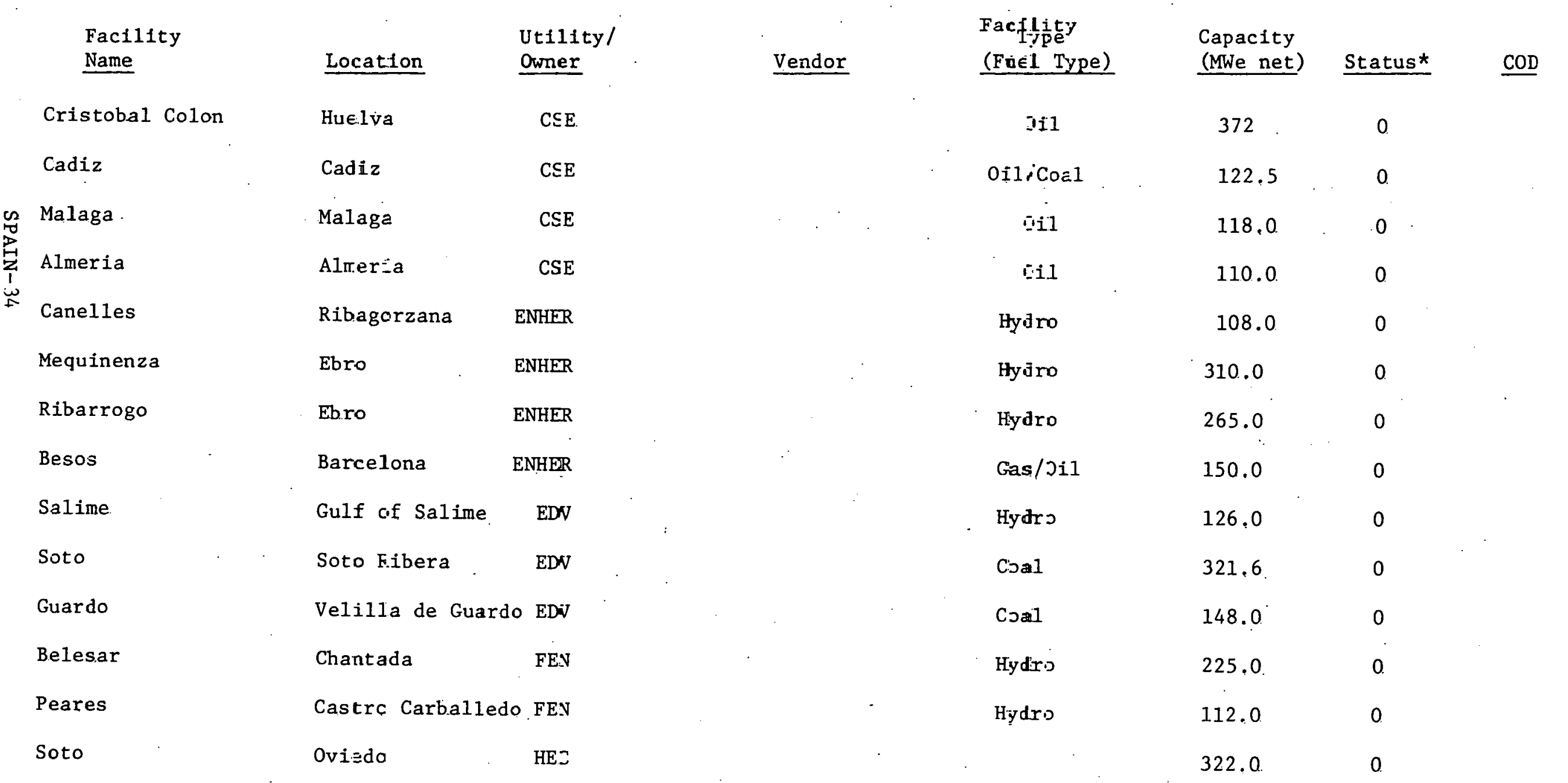

* O-Operational; U-Inder Constructicn; P-Planned; S-Shutdown 
ENERGY GENERATION FECILITIES IN EXISTENCE AND FIRMLY PLANNED PRODUCING 100 MWe (nEt)

Table 24.6.1 (continued)

Facility

Name

Salime

Alcantara

Valdecanas

Azutan

Torrejor:

CJfrentes

Escombreras

Aceca

Aldeadavila

Saucelle

Villarino

Esla

Compostella 1

\begin{tabular}{ll} 
Utility/ & Owner \\
\hline
\end{tabular}

Asturias

HEC

HEE

HEE

HEE

HEE

HEE

HEE

HEE

HEII

HEII

HEII

HEII

\section{Facility \\ Type \\ (Fuel Type)}

Hydro

Hydro

Hydro

Hydro

Hydro

Hydro

011

$0 i 1$

Hydro

Hydro

Hydro

Hydro

Coal
Capacity

(MWe net) Status* COD

112.0

915.2

225.0

$180.0^{\circ}$

129.6

124.2

858.0

313.6

718.2

240.0

540.0

133.0

167.0
0 .

0

0

0

0

0

0

0

0

0

0

* O-Operational; U-Under Construction; P-Planned; S-Shutdown 


\section{ENERGY GINERATION IACILITIES IN EXISTENCE AND FIRMEY PLANNED FRODUCING 100 MWe (net)}

Table 24.6.1 (continued)

Facility

Name

Compostella II

La Robla

$n$
2
2
2
1
0
0

Narcea

Lada

Escatron

Escucha

Puentes 1400

ENE

Serchs

Algeciras

Badelona I

Badelona II

Castel1on

Mata

Dwner

Location $\begin{aligned} & \text { Utility/ } \\ & \text { Dwner }\end{aligned}$

Vendor

Facility

Typ?
Fuel Type

\section{Capacity}

(MWe net)

Status* COD

Coal

612.0

0

Coal

270.0

0

Coa1

219.0

0

Coal

255.0

0

Lignite

172.5

Lignite

175.0

350.0

175.0

753.0

137.0

344.0

$1,083.4$

126.0
Dil

Dil

Di 1 -ignite

1

1

1




\section{ENERGY GENERATION FACILITIES IN EXISTENCE AND FIRMIY PLANNED PRODUCING 100 MWe (net)}

Table 24.6.1 (continued)

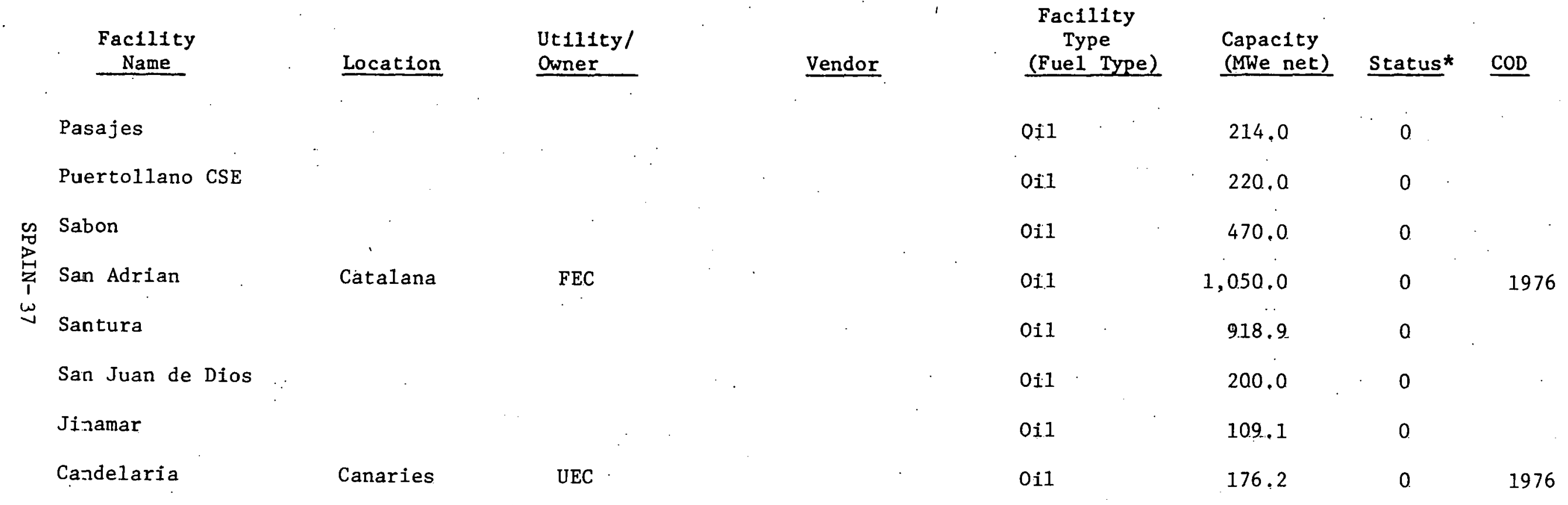




\section{SUMMARY OF ENERGY GENERATION FACILITIES IN EXISTENCE AND PLANNED}

Table 24.6.2

$\underline{\text { Year }}$

1975

1980

1985

1990

1995

2000

\section{Capacity - MWe (net)}

$$
24,534
$$


LISTING OF FUEL SUPPLY FACILITIES IN EXISTENCE AND FIRMLY PLANNED

Table 24.6 .3

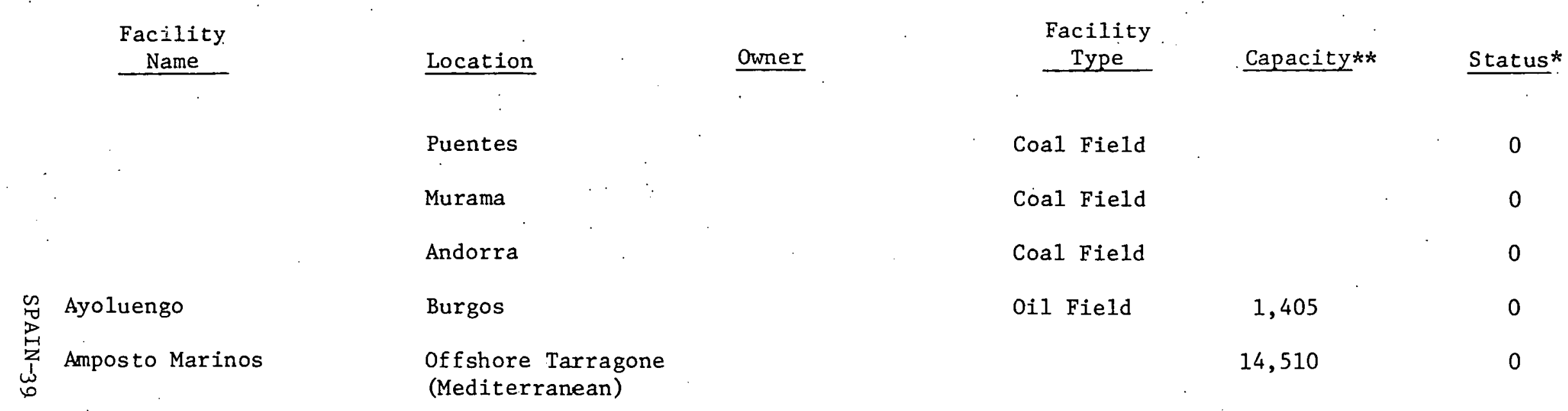

* O-Operationa1; U-Under Construction; P-P1anned; S-Shutdown

* Coal - million tonnes/year; 0il - barrels/day 
Table 24.6 .4

RESOURCE

COAL (million tonnes)

Indigenous Supply

17.16

0.64

19.24

Imports

Exports

8.86

CRUDE OIL (million tonnes)

Indigenous Supply

Imports

2.17

2.63

Exporte

36.33

$7 / .67$

SHALE OIL (million tonnes)

Indigenous Supply

0

0

Imports

Exports

NATURAL GAS (cubic kilometers)

Indigenous Supply

Imports

0.02

0.01

Exports

0.58

0.39

URANIUM (kilotonnes $\mathrm{U}_{3} \mathrm{O}_{8}$ )

Indigenuus supply

1.5

2.1

Imports

0.4

1.15

Exports

0

0 